\section{Pacific Northwest}

National Laboratory

Operated by Battelle for the

U.S. Department of Energy

\title{
RCRA Assessment Plan for Single-Shell Tank Waste Management Area T
}

\author{
D. G. Horton
}

May 2006

Prepared for the U.S. Department of Energy under Contract DE-AC05-76RL01830 


\title{
DISCLAIMER
}

This report was prepared as an account of work sponsored by an agency of the United States Government. Reference herein to any specific commercial product, process, or service by trade name, trademark, manufacturer, or otherwise does not necessarily constitute or imply its endorsement, recommendation, or favoring by the United States Government or any agency thereof, or Battelle Memorial Institute.

\author{
PACIFIC NORTHWEST NATIONAL LABORATORY \\ operated by \\ BATTELLE \\ for the \\ UNITED STATES DEPARTMENT OF ENERGY \\ under Contract DE-AC05-76RL01830
}

\author{
Printed in the United States of America \\ Available to DOE and DOE contractors from the \\ Office of Scientific and Technical Information, P.O. Box 62, Oak Ridge, TN 37831; \\ prices available from (615) 576-8401.
}

Available to the public from the National Technical Information Service,

U.S. Department of Commerce, 5285 Port Royal Rd., Springfield, VA 22161

This document was printed on recycled paper. 


\title{
RCRA Assessment Plan for Single-Shell Tank Waste Management Area T
}

\author{
D. G. Horton
}

May 2006

Prepared for

the U.S. Department of Energy

under Contract DE-AC05-76RL01830

Pacific Northwest National Laboratory

Richland, Washington 99352 


\section{Summary}

Waste Management Area (WMA) T is regulated under the Resource Conservation and Recovery Act (RCRA) as modified in 40 CFR Part 265, Subpart F and Washington State's Hazardous Waste Management Act (HWMA, RCW 70.105 and its implementing requirements in the Washington State dangerous waste regulations [WAC 173-303-400]). WMA T was placed in assessment monitoring in 1993 because of elevated specific conductance. A groundwater quality assessment plan was written in 1993 (Caggiano and Chou 1993) describing the monitoring activities to be used in deciding whether WMA T had affected groundwater. That plan was updated in 2000 (Hodges and Chou 2001) for continued RCRA groundwater quality assessment as required by 40 CFR 265.93 (d)(7). This document further updates the assessment plan for WMA T by including (1) information obtained from seven new wells installed at the WMA after 1999 and (2) information from routine quarterly groundwater monitoring during the last five years. Also, this plan describes activities for continuing the groundwater assessment at WMA T.

This plan describes the data quality objectives process used to guide information gathering to further the assessment at WMA T. The general approach of the assessment is to (1) determine the optimum locations for new monitoring wells to improve the assessment of and the probability of detecting contaminants from the WMA, (2) determine the depth distribution of contaminants within the uppermost aquifer, (3) improve estimates of hydraulic properties that influence the distribution of contaminants in the aquifer, (4) delineate the lateral extent and the concentrations of contaminants and their relation ship to potential sources within the study boundary, and (5) continue routine quarterly groundwater sampling and analysis to comply with RCRA regulatory requirements.

This assessment plan includes a sampling and analysis plan (Appendix A) consisting of a field sampling plan and an quality assurance project plan. The sampling and analysis plan is used as the

principal controlling document for conducting the work identified by the data quality assessment process. 


\section{Contents}

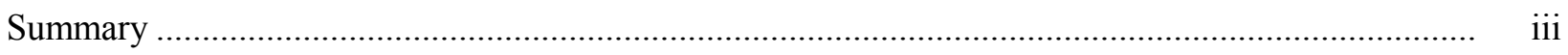

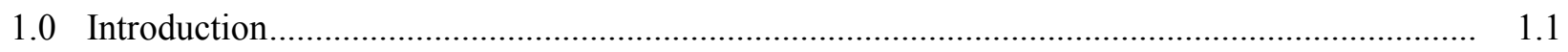

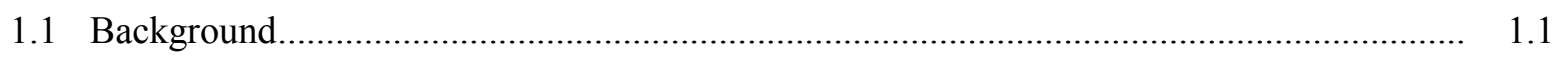

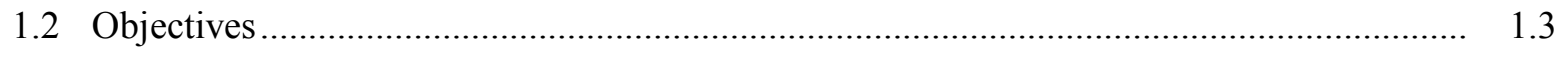

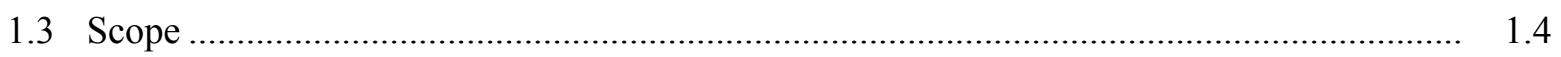

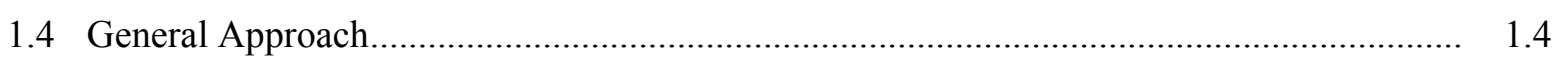

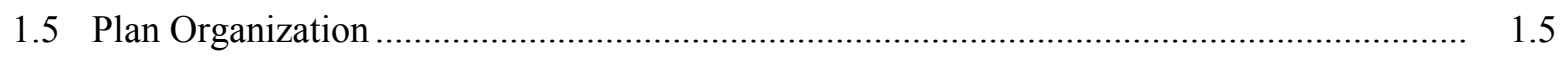

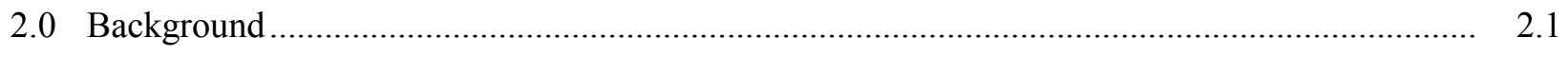

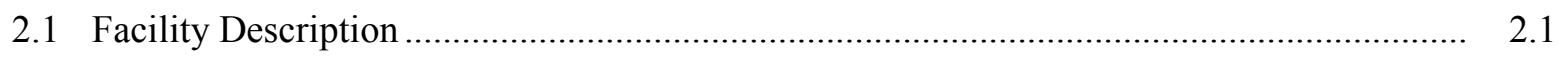

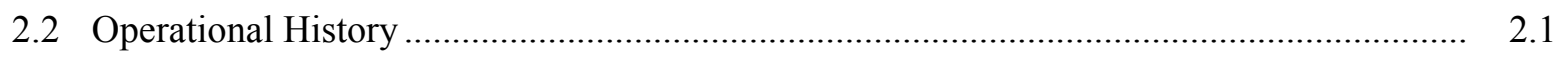

2.3 Tank Leaks and Unplanned Releases .................................................................... 2.2

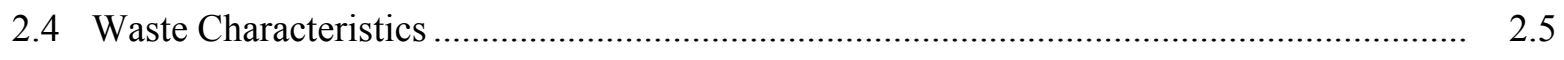

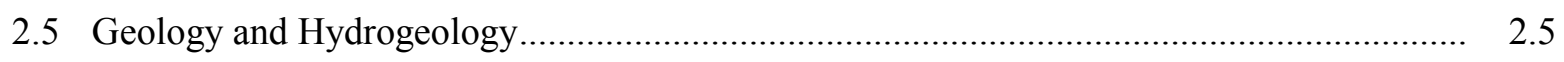

2.5.1 Stratigraphy and Lithology at Waste Management Area T .................................. 2.8

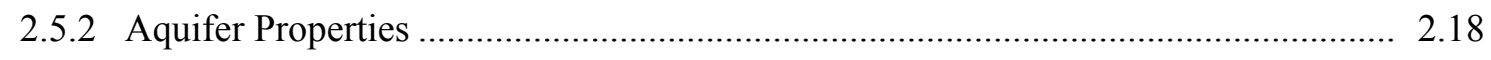

2.6 Contamination at Waste Management Area T .................................................................. 2.24

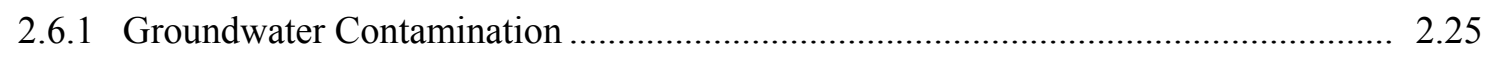

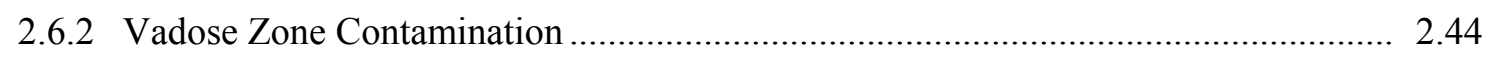

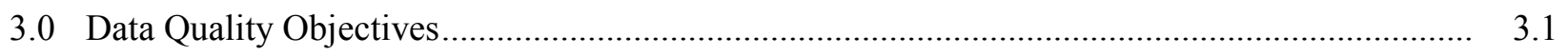

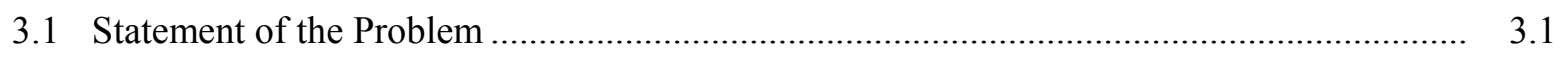

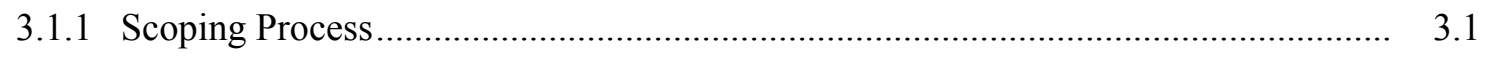

3.1 .2 Regulatory Drivers ….............................................................................. 3.2

3.1.3 Conceptual Model for Waste Management Area T .............................................. 3.2

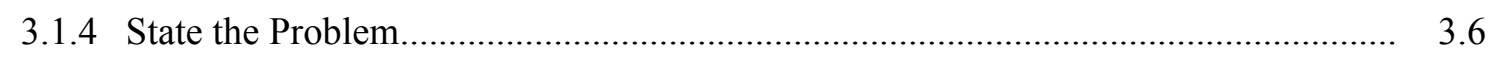

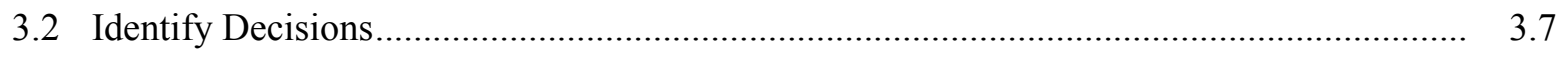

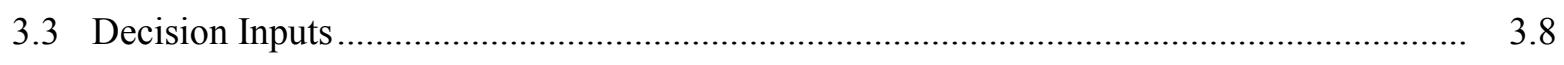

3.3.1 Groundwater Flow Rate and Direction ..................................................... 3.8

3.3.2 Extent of Contamination............................................................................ 3.10

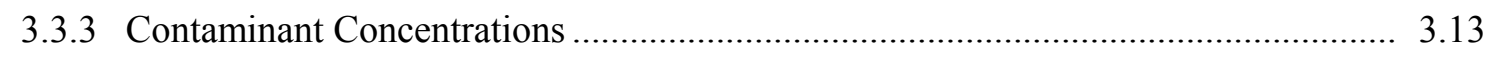

3.3.4 Contaminant Sources, Driving Forces, and Migration Pathways............................. 3.14

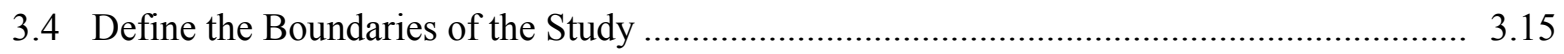

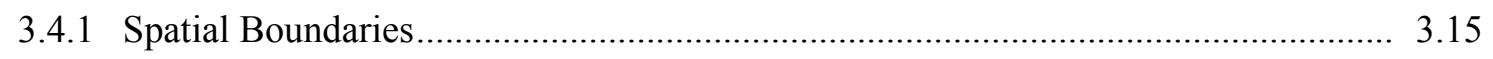

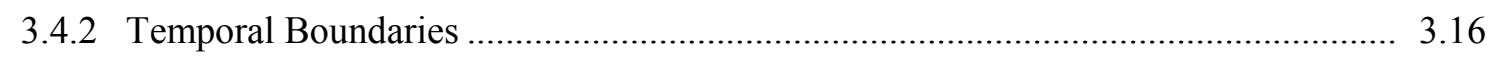

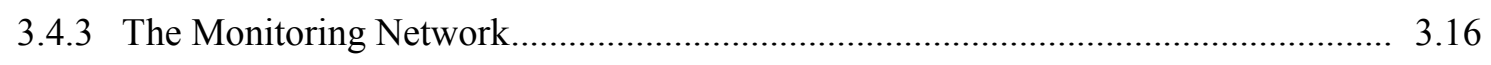




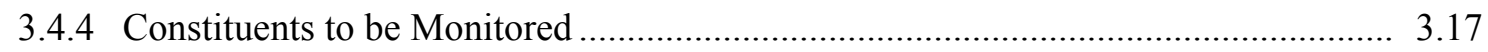

3.4.5 Practical Constraints............................................................................... 3.19

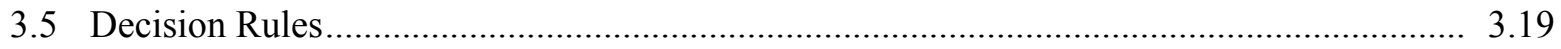

3.5.1 Groundwater Flow Rate and Direction .......................................................... 3.19

3.5.2 Extent of Contamination.............................................................................. 3.19

3.5.3 Sampling and Analysis Considerations ............................................................. 3.21

3.5.4 Contaminant Source(s), Migration Pathways, and Driving Mechanisms ................. 3.22

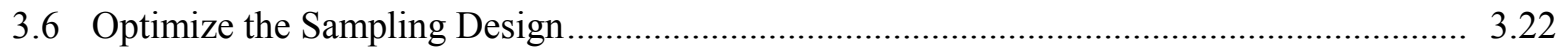

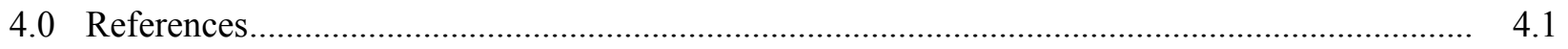

Appendix A - Sampling and Analysis Plan

Appendix B - Supporting Information

\section{Figures}

1.1 Location Map for Waste Management Area T

1.2 General Layout of Waste Management Area T including Locations of Nearby Past-Practice Facilities and Monitoring Wells.

2.1 The Locations of Wells and Cross-Section at Waste Management Area T............................. 2.8

2.2. Generalized Stratigraphic Column for the Hanford Site...................................................... 2.10

2.3. Cross-Section of the Geology North of Waste Management Area T...................................... 2.11

2.4. Cross-Section of the Geology East (downgradient) of Waste Management Area T ................. 2.12

2.5. Cross-Section of the Geology Beneath Waste Management Area T ........................................ 2.13

2.6. Structure Contour Maps for Selected Units Under Waste Management Area T ...................... 2. 2.15

2.7. Thickness Maps for Selected Units Under Waste Management Area T.................................. 2.16

2.8 Hydrographs of Selected Wells in North 200 West Area ...................................................... 2.18

2.9. Groundwater Flow Directions in the North Part of 200 West Area......................................... 2.20

2.10 March 2004 Water-Table Map for the Area Around Waste Management Area T ................... 2.21

2.11 Hydrographs for Two Wells at Waste Management Area T................................................... 2.24

2.12 Average Concentration of Carbon Tetrachloride in the 200 West Area, Top of the Unconfined Aquifer ................................................................................................... 2.26

2.13 Average Concentrations of Trichloroethene in the North Part of the 200 West Area, Top of the Unconfined Aquifer............................................................................................. 2.27

2.14 Average Concentrations of Tritium in the North Part of 200 West Area, Top of the Unconfined Aquifer .

2.15 Average Concentrations of Nitrate in the North Part of 200 West Area, Top of the Unconfined Aquifer 
2.16. Average Concentrations of Fluoride in the Area of Waste Management Area T, Top of the Unconfined Aquifer.

2.17 Technetium-99 and Fluoride Concentrations in Downgradient Well 299-W-10-24

2.18. Average Concentrations of Technetium-99 in the Area of Waste Management Area T, Top of the Unconfined Aquifer.

2.19. Technetium-99 Concentrations in Wells at the Northeast Corner of Waste Management Area T

2.20. Technetium-99 Concentrations in Selected Downgradient Wells at Waste Management Area T

2.21. Concentrations of Technetium-99 and Nitrate Versus Depth Below the Water Table in Well 299-W11-25B

2.22. Concentrations of Chromium and Manganese Versus Depth Below the Water Table in Well 299-W11-25B

2.23. Current Groundwater Monitoring Network for Waste Management Area $T$

2.24. Technetium-99 and Nitrate Concentrations Encountered During Drilling of Well 299-W11-45

2.25. Average Concentrations of Chromium in the Area of Waste Management Area T, Top of the Unconfined Aquifer....

2.26 Technetium-99 and Chromium Concentrations in Selected Wells at Waste Management Area T.

2.27. Technetium-99/Chromium Concentration Ratios in Samples from Selected Wells at Waste Management Area T.

2.28. Technetium-99/Chromium Composition Ratios for A: Pore Water at the Tank T-106 Leak and B: Two New Monitoring Wells at Waste Management Area T.

2.29. Technetium-99/Nitrate Concentration Ratios in Samples from Selected Wells at Waste Management Area T.

2.30. Technetium-99/Nitrate Composition Ratios for A: Pore Water at the Tank T-106 Leak and B: Two New Monitoring Wells at Waste Management Area T.

2.31 Vadose Zone Contamination in the T Tank Farm.

\section{Tables}

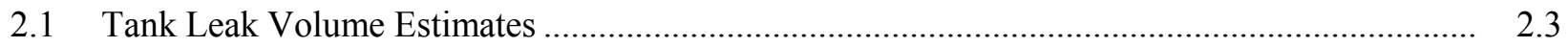

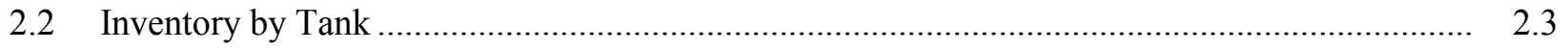

2.3 Tank Contents and Waste Received for the T Tank Farm Single-Shell Tanks ........................ 2.6

2.4 Partial Inventory Estimates for Tank Leak Fluids from Tanks in Waste Management Area T.

2.5 In-Well, Downward Vertical, Flow-Velocity Summary for Wells 299-W11-39 and 299-W11-40 at Waste Management Area T. 
2.6 Results from Tracer-Dilution and Tracer-Pumpback Tests in Wells at Waste Management Area T.

2.7 Hydraulic Properties from Slug and Constant Rate Pumping Tests and Calculated Horizontal Flow Velocities at New Wells at Waste Management Area T .

2.8 Calculated Life Expectancy for Wells in the Waste Management Area T Monitoring Network

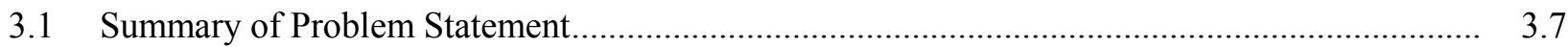

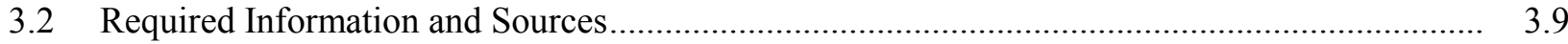

3.3 Constituents of Concern, Constituents of Interest, and Supporting Groundwater Quality Constituents to be Monitored at Waste Management Area T ..................................................... 3.18

3.4 Summary of Decision Rules .............................................................................................. 3.20 


\subsection{Introduction}

Waste Management Area (WMA) T, containing the T Tank Farm, is located in the northern portion of the 200 West Area (Figure 1.1) and was used for the interim storage of radioactive waste from chemical processing of reactor fuel for plutonium production. The WMA is regulated under the Resource Conservation and Recovery Act (RCRA) as modified in 40 CFR Part 265, Subpart F and Washington State's Hazardous Waste Management Act (HWMA, RCW 70.105 and its implementing requirements in the Washington State dangerous waste regulations [WAC 173-303-400]). WMA T was placed in assessment monitoring in 1993 because of elevated specific conductance, a RCRA indicator parameter, in one downgradient well. A groundwater quality assessment plan was written in 1993 (Caggiano and Chou 1993) describing the monitoring activities to be used in deciding whether WMA T had affected groundwater. That plan was updated in 2000 (Hodges and Chou 2001) for continued RCRA groundwater quality assessment as required by 40 CFR 265.93 (d)(7). This document further updates the assessment plan for WMA T by including (1) information obtained from seven new wells installed at the WMA since the previous plan was issued and (2) information from routine, quarterly groundwater monitoring during the last five years. Also, this plan describes activities for continuing the groundwater assessment at WMA T. All information pertinent to the WMA T groundwater assessment available through October 2005 is considered in this plan.

\subsection{Background}

Figure 1.2 shows the general layout of WMA T. A detection level RCRA groundwater monitoring program for WMA T was initiated in 1989 (Jensen et al. 1989; Caggiano and Goodwin 1991). The WMA was placed into assessment monitoring in 1993 because specific conductance values in downgradient well 299-W10-15 exceeded the upgradient background value (critical mean) of $1,175 \mu \mathrm{S} / \mathrm{cm}$ (Caggiano and Chou 1993). Elevated specific conductance values in well 299-W10-15, principally a result of elevated sodium and nitrate from an upgradient source, dropped below the critical mean in 1994. However, before the WMA could be returned to a detection level monitoring program, specific conductance in well 299-W11-27 started a rapid increase in late 1995 and exceeded the critical mean in early 1996. In the case of well 299-W11-27, the increased specific conductance was accompanied by elevated technetium-99, tritium, nitrate, calcium, magnesium, sulfate, chromium, cobalt-60, and total organic carbon. In February 1997, technetium-99, the principal contaminant, reached a maximum concentration of $21,700 \mathrm{pCi} / \mathrm{L}, 24$ times the drinking water standard of $900 \mathrm{pCi} / \mathrm{L}$.

The first assessment report (Hodges 1998) did not identify an upgradient source for the contamination observed in monitoring well 299-W11-27, and indeed found evidence linking the contaminants in groundwater to the WMA. Accordingly, continuation of the groundwater assessment is required. This plan describes the activities for the continued assessment. 


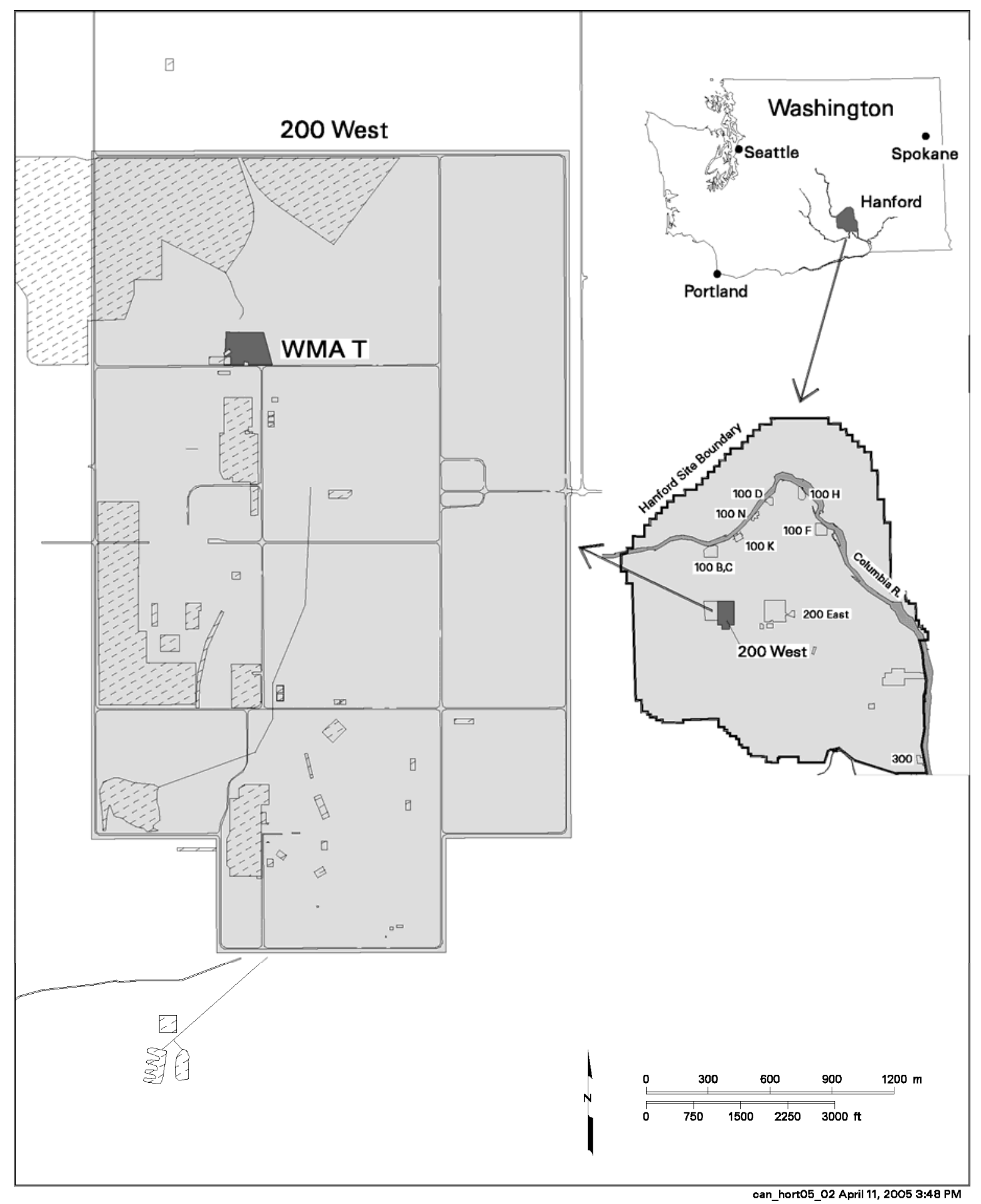

Figure 1.1. Location Map for Waste Management Area $T$ 


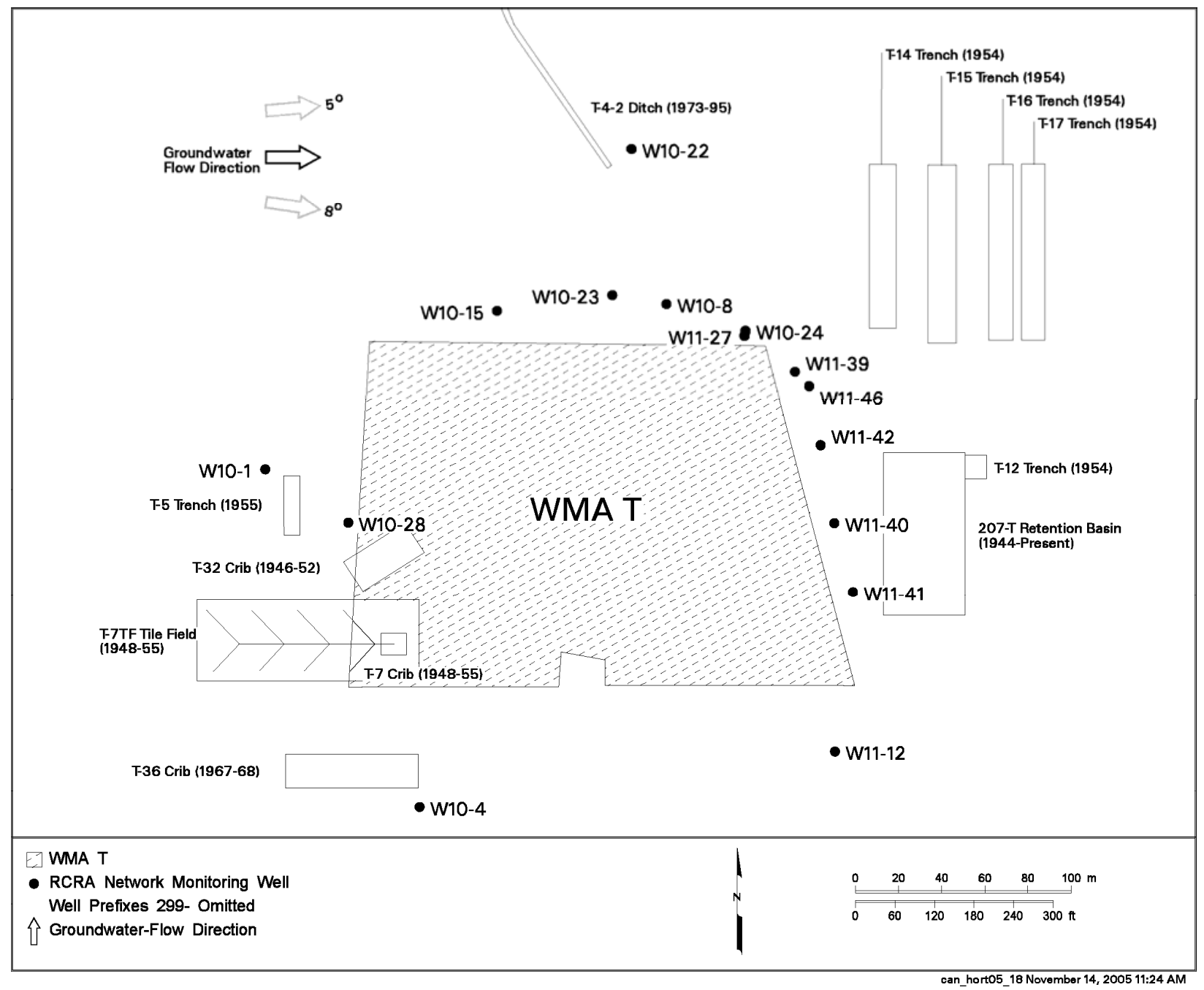

Figure 1.2. General Layout of Waste Management Area T including Locations of Nearby Past-Practice Facilities and Monitoring Wells

\subsection{Objectives}

The objectives for the continued assessment of groundwater quality at WMA T, as required by 40 CFR 265.93(d)(7)(i), are to determine

(i) the rate and extent of migration of the hazardous waste or hazardous waste constituents in the groundwater and

(ii) the concentration of hazardous waste or hazardous waste constituents in the groundwater.

These objectives are related to the Comprehensive Environmental Resource Conservation Act (CERCLA) 200-ZP-1 operable unit remedial investigation/ feasibility study and the RCRA vadose zone RCRA facility investigation/corrective measures study (RFI/CMS) at WMA T as described in the Hanford Federal Facility Agreement and Consent Order Change Request M-45-98-03 (Tri-Party Agreement, Ecology et al. 1989). In accordance with the agreement between the U.S. Department of 
Energy (DOE), and the Washington State Department of Ecology (Ecology) concerning this change request, the continuing RCRA groundwater quality assessment and the RFI/CMS work will be conducted under separate but coordinated plans. Data from the RCRA groundwater quality assessment will be used in RFI/CMS planning and will be included either by reference or directly with the vadose zone data from the RFI/CMS efforts in a field investigation report due July 2005 (milestone M-45-55-T03).

Key questions related to the above objectives are:

1. What is the vertical and horizontal concentration profile of all dangerous waste constituents in vadose zone and groundwater released from WMA T?

2. What is the rate and extent of contaminant migration in the groundwater?

3. What are the likely source(s) for the observed groundwater contamination at WMA T?

4. What are the likely driving forces for observed groundwater contamination at WMA T?

5. What are the groundwater flow rate and flow direction?

The groundwater quality assessments for the single-shell tank WMAs are conducted by Pacific Northwest National Laboratory (PNNL) for DOE. Also, in accordance with the cleanup objective for Hanford Site tank farms, the groundwater investigations will be planned and implemented to support decisions on interim measures, corrective measures, waste retrieval, and eventual closure of the tank farms.

\subsection{Scope}

The scope of this plan is to acquire the necessary groundwater data to reach the above objectives and integrate the RCRA groundwater quality assessment with the 200-ZP-1 groundwater operable unit and the vadose zone RFI/CMS.

Groundwater monitoring objectives of RCRA, CERCLA, and the Atomic Energy Act (AEA) often differ slightly and the contaminants monitored are not always the same. For RCRA regulated units, monitoring focuses on non-radioactive dangerous waste constituents. Radionuclides (source, special nuclear and by-product materials) may be monitored in some RCRA unit wells to support objectives of monitoring under the AEA and/or CERCLA. Please note that pursuant to RCRA, the source, special nuclear and by-product material component of radioactive mixed wastes are not regulated under RCRA and are regulated by DOE acting pursuant to its AEA authority. Therefore, while this report may be used to satisfy RCRA reporting requirements, the inclusion of information on radionuclides in such a context is for information only and may not be used to create conditions or other restrictions set forth in any RCRA permit.

\subsection{General Approach}

The data quality objectives (DQO) process was used to guide information gathering to further the assessment at WMA T. The resulting, general approach to meet the specific or immediate objectives for 
the continued assessment (i.e., to determine the concentration, rate of movement and extent of contamination) includes the following major components:

- Determine optimum locations for new monitoring wells to improve the assessment of and the probability of detecting contaminants from the WMA. A reliable detection network is also important to demonstrate the effectiveness of any interim corrective measures undertaken as a result of the RFI/CMS process.

- Determine depth distribution of contaminants within the aquifer by discrete depth sampling during drilling of new wells and by sampling multiple depths within the screened intervals of existing wells.

- Conduct hydrologic testing on selected wells to obtain estimates of hydraulic conductivity, effective porosity, and preferential flow zones within the screened interval of monitoring wells. This information will be used in concert with new water-level data to determine groundwater flow velocities and to determine optimal locations of sampling intervals within the well screen intervals.

- Use spatial and temporal mapping of the contaminant plumes to delineate the extent and concentration of contaminants and their relationship to potential sources within the study boundary. In concert with hydrogeologic data, estimate the approximate rate, direction, and extent of contaminant migration.

- Use the results of special isotopic studies to aid the identification of contaminant sources (e.g., differentiation of tank leaks, distinguish cribs versus tanks, etc.) affecting groundwater quality.

- Continue routine, quarterly groundwater sampling and analysis to comply with RCRA regulatory requirements.

\subsection{Plan Organization}

A review of existing data including waste characteristics, geology and hydrology, and vadose zone and aquifer contamination are presented in Chapter 2.0. The DQO process for this groundwater assessment is given in Chapter 3.0. An updated conceptual model is given as part of the DQO chapter. References cited are listed in Chapter 4.0. A sampling and analysis plan (including a field sampling plan and a quality assurance plan) for the groundwater quality assessment at WMA T is included in Appendix A. Appendix B gives pertinent hydrogeologic and monitoring well information. 


\subsection{Background}

\subsection{Facility Description}

WMA T occupies an area of about $32,000 \mathrm{~m}^{2}$ and contains 16 underground single-shell tanks constructed in 1943 and 1944 (Figure 1.2). Twelve tanks (T-101 through T-112) have capacities of 2,006,286 liters and four tanks (T-201 through T-204) have capacities of 208,200 liters. In addition to the tanks, six diversion boxes and ancillary pumps, valves and pipes are included in the Hanford Facility Dangerous Waste Part A Permit Application (DOE 2000b) for single-shell tank farm system T. Two cribs, 216-T-7 and 216-T-32, are within the tank farm fence but are not included in the single-shell tank Part A permit application.

The single shell tanks are constructed of carbon steel (ASTM A283 Grade C) lining the bottom and sides of a reinforced concrete shell. The concrete dome top is unlined. The larger tanks are 22.9 meters in diameter and are about 9 meters in height. The bottoms of the tanks are about 11 meters below grade with approximately 2.1 meters of fill over the top. Various ports in the tank tops are available for waste transfer and monitoring. In addition, vadose zone monitoring wells (drywells) are located around the tanks and extend generally to 22 to 45 meters depth to allow monitoring of radionuclide and moisture migration outside the tanks by geophysical methods.

The smaller tanks are 6.1 meters in diameter and 7.8 meters in height. The bottoms of the smaller tanks are at about 11.4 meters below grade with about 3.6 meters of fill over the top. Numerous buried waste transfer lines run into the tank farm to diversion boxes where wastes were routed to various tanks through valve boxes.

The routing of liquid waste from the operations buildings to the tank farms was done with underground lines and diversion boxes. The diversion boxes are concrete boxes that were designed to contain any waste that leaked from the high-level waste transfer line connections. Diversion boxes generally drained to nearby catch tanks where any spilled waste was stored and then pumped to single-shell tanks. It is estimated that each diversion box contains 23 kilograms of lead (DOE 2000b).

\subsection{Operational History}

The tanks in WMA T began receiving waste in 1944 and were more-or-less in continual use from that time until 1980, at which time all tanks in the waste management area had been removed from service. The single-shell tanks received predominantly high-level metal and first cycle waste from chemical processing of uranium-bearing spent fuel rods. Lesser amounts of other waste types were also stored in the tanks at WMA T. After fuel rod dissolution, metal waste was the first waste stream generated in the bismuth phosphate process. Metal waste contained about $60 \mathrm{~g} / \mathrm{L}$ of uranium and about $90 \%$ of the fission product radionuclides originally present in the irradiated fuel rods (Jones et al. 2000). First cycle waste was generated from the first precipitation step after the generation of metal waste. The composition of first cycle waste should be similar to the metal waste, but without the uranium (Jones et al. 2000).

Waste management operations have created a complex intermingling of the tank wastes. Nonradioactive chemicals have been added to the tanks and varying amounts of waste- and heat-producing 
radionuclides have been removed. In addition, natural processed have caused settling, stratification, and segregation of waste components. Waste was also cascaded (allowed to flow by gravity from one tank to another) through a series of tanks; cooling and precipitation of radionuclides and solids occurred in each tank of the cascade. Some of the supernatant from the last tank in a cascade was sent to cribs because of shortage of tank storage capacity. As a result, it is very difficult to estimate the composition of the wastes remaining in the tanks through operational records. A detailed history of tank farm operations is given by Anderson (1990).

The 216-T-7 crib operated between April 1948 and November 1955. During that time, the crib received 110 million liters of a combination of second-cycle, T-Plant cell drainage waste, and plutonium concentrator waste (Williams 2000). The 216-T-32 crib operated between 1946 and 1952. During that time, it received 29 million liters of "224 waste" (defined as low-level waste containing plutonium in Williams 2000) from the 224-T building by way of the 241-T-201 single-shell tank.

In addition to the above two cribs, several other liquid disposal facilities are located adjacent to the tank farm but outside the tank farm fence. About 785,000 to 1 million liters of first-cycle waste were discharged to each of the 216-T-14 through 216-T-17 specific retention trenches northeast of the T Tank Farm in 1954. In 1967 and 1968, about 522,000 liters of decontamination waste and condensate were discharged to the 216-T-36 crib southwest of the T Tank Farm. The 216-T-5 crib, located just west of the T Tank Farm, received about 2.6 million liters of second cycle waste in 1955 (Williams 2000).

Initial corrective actions have been implemented at WMA T. Berms were constructed around the $\mathrm{T}$ Tank Farm in 2001 to stop run-on of natural precipitation. Also, all known water lines have been tested or cut off. Finally, an interim surface barrier is planned to be tested at tank T-106. The barrier will consist of a ground cover consisting of about 1.3 centimeters of polyurethane.

\subsection{Tank Leaks and Unplanned Releases}

Seven of the tanks at WMA T have been declared leakers based on liquid losses (Hanlon 2004). Information about these leaks is given in Table 2.1. Although Hanlon gives estimated leak volumes for tanks T-107, T-108, T-109, and T-111 based on observed liquid levels in the tanks, neither the spectral gamma logging data (GJO-99-101-TAR) nor tank waste transfer records provide evidence of leaks from these tanks (Jones et al. 2000). Contamination associated with these tanks may be from waste pipeline leaks or from nearby tanks that are known to have leaked.

All seven of the tanks listed by Hanlon as "assumed leakers" have been interim stabilized. Interim stabilized means that the tank now contains less than 189,250 liters of drainable interstitial liquid and less than 18,925 liters supernatant liquid (Hanlon 2004). The volume contents of each tank in WMA T are given in Table 2.2 .

Tank T-101 was overfilled in the 1960s and lost between about 28,000 and 38,000 liters of reduction/ oxidation (REDOX) cladding waste through a defective spare inlet port in 1969 (Jones et al. 2000). Spectral gamma logs are consistent with waste loss through a spare inlet port. Also, waste transfer records suggest a waste loss of between 3,700 and 11,400 liters through a spare inlet port when tank T-103 was overfilled in 1972 and 1973. 
Table 2.1. Tank Leak Volume Estimates

\begin{tabular}{||l|c|c|c|c||}
\hline \hline \multicolumn{1}{|c|}{ Tank Number } & $\begin{array}{c}\text { Date Declared or } \\
\text { Confirmed, or } \\
\text { Assumed Leaker }\end{array}$ & $\begin{array}{c}\text { Volume Leaked } \\
(\mathrm{L})^{(\mathrm{a})}\end{array}$ & $\begin{array}{c}\text { Volume Leaked } \\
(\mathrm{L})^{(\mathrm{b})}\end{array}$ & $\begin{array}{c}\text { Interim Stabilized } \\
\text { Date }\end{array}$ \\
\hline \hline $241-T-101$ & 1992 & 28,400 & 37,850 & $04 / 93$ \\
\hline $241-T-103$ & 1974 & $<3,785$ & 11,355 & $11 / 83$ \\
\hline $241-T-106$ & 1973 & 435,275 & 435,275 & $08 / 81$ \\
\hline $241-T-107$ & 1984 & $\sim 30,280$ & $\begin{array}{c}\text { No basis for } \\
\text { estimate }\end{array}$ & $05 / 96$ \\
\hline $241-T-108$ & 1974 & $<3,785$ & 3,785 & $11 / 78$ \\
\hline $241-T-109$ & 1974 & $<3,785$ & 3,785 & $12 / 84$ \\
\hline $241-T-111$ & 1979 and 1994 & $<3,785$ & 3,785 & $02 / 95$ \\
\hline $\begin{array}{l}\text { (a) From Hanlon (2004). } \\
\text { (b) From Field and Jones (2005). }\end{array}$ \\
\hline
\end{tabular}

Table 2.2. Inventory by Tank (Hanlon 2004)

\begin{tabular}{||l|l|c|r|r||}
\hline \multicolumn{1}{|c|}{ Tank } & \multicolumn{1}{|c|}{ Tank Integrity } & $\begin{array}{c}\text { Drainable Liquid } \\
\text { Remaining (L) }\end{array}$ & Sludge (L) & Salt Cake (L) \\
\hline \hline $241-\mathrm{T}-101$ & Assumed Leaker & 79,500 & 140,060 & 242,270 \\
\hline $241-\mathrm{T}-102$ & Sound & 60,560 & 71,920 & 0 \\
\hline $241-\mathrm{T}-103$ & Assumed Leaker & 26,500 & 87,060 & 0 \\
\hline $241-\mathrm{T}-104$ & Sound & 117,350 & $1,199,980$ & 0 \\
\hline $241-\mathrm{T}-105$ & Sound & 18,930 & 370,970 & 0 \\
\hline $241-\mathrm{T}-106$ & Assumed Leaker & 7,570 & 71,920 & 0 \\
\hline $241-\mathrm{T}-107$ & Assumed Leaker & 128,700 & 654,880 & 0 \\
\hline $241-\mathrm{T}-108$ & Assumed Leaker & 18,930 & 79,500 & 87,060 \\
\hline $241-\mathrm{T}-109$ & Assumed Leaker & 37,850 & & 219,550 \\
\hline $241-\mathrm{T}-110$ & Sound & 181,700 & $1,393,030$ & 0 \\
\hline $241-\mathrm{T}-111$ & Assumed Leaker & 143,850 & $1,688,290$ & 0 \\
\hline $241-\mathrm{T}-112$ & Sound & 41,640 & 227,120 & 0 \\
\hline $241-\mathrm{T}-201$ & Sound & 18,930 & 105,990 & 0 \\
\hline $241-\mathrm{T}-202$ & Sound & 11,360 & 79,500 & 0 \\
\hline $241-\mathrm{T}-203$ & Sound & 18,930 & 132,490 & 0 \\
\hline $241-\mathrm{T}-204$ & Sound & 18.930 & 143,850 & 0 \\
\hline \hline
\end{tabular}

The largest tank leak at WMA T is associated with tank T-106. The leak was about 435,300 liters of tank waste that is suspected to have started in May 1973 but was not detected until June 1973. The waste lost from this leak originated from B Plant isotope recovery processes. Approximately $25,000 \mathrm{~m}^{3}$ of soil were contaminated to a depth of 33 meters, based on the estimated $1 \mu \mathrm{Ci} / \mathrm{L}$ ruthenium isopleth obtained from gamma energy analyses of vadose zone samples (ARH 1973). The leak was investigated in 1973 
(ARH 1973), in 1979 (Routson et al. 1979), and in 1992 (Freeman-Pollard et al. 1994). The conclusion of the latter investigation was that contaminants in the leading edge of the vadose zone plume had penetrated to the contact between the Ringold Formation unit E and the overlying Taylor Flats member of the Ringold Formation at about 37 meters below ground surface. However, that same report states that a small amount of technetium-99 had penetrated into the Ringold Formation unit $\mathrm{E}$ to a depth of 44 meters.

Most recently, Serne et al. (2004) made an extensive analytical characterization of sediment samples from two boreholes cored near tank T-106. They concluded that nitrate had migrated about 1.8 meters and cobalt -60 had migrated about 3 to 4.6 meters deeper in 2003 than in 1993 . The deepest cobalt- 60 was at 34.4 meters and the deepest nitrate was at about 38.7 meters below ground surface. Serne et al. 2004 also concluded that there was no vertical migration of actinides between 1993 and 2003. Data for determining the extent of subsurface movement of other contaminants were inconclusive.

In addition to leaks, nine unplanned releases have been documented. The following information about those releases is from DOE (1991).

- Unplanned release UN-200-W-7 occurred in 1950 at the 241-T-151 and 241-T-152 diversion boxes. The material and amount released are not documented. Contaminated soil was partly removed and the remainder of contaminated soil was covered with approximately 0.3 meter of clean soil.

- Unplanned release UN-200-W-14 occurred in October 1952 along the waste line connecting the 242-T building and the 207-T retention basin. The release was detected when contaminated water rose to the ground surface above the waste line. The waste line was repaired and the contaminated soil was covered with approximately 0.3 meter of soil. The specific contaminant and the amount of contaminant released are not documented in DOE/RL-91-61 or in the Waste Information Data System.

- Unplanned release UN-200-W-29 occurred in November 1954 at a cave-in approximate 23 meters east of Camden Avenue and 23 meters south of $23^{\text {rd }}$ Street, between the 241-T-152 and 241-TX-153 diversion boxes. The unplanned release resulted from failure of an uncased line connecting the diversion boxes. First-cycle supernatant waste from the 241-T-105 single-shell tank was released with dose rates of $11.5 \mathrm{R} /$ hour at 5 centimeters. The area was hosed down with water and backfilled. A second spill occurred at the same location in May 1966 due to reuse of the same line. The amount of material released is not documented in DOE (1991) or the Waste Information Data System (WIDS).

- Unplanned release UN-200-W-62 occurred in May 1966 at the corner of $23^{\text {rd }}$ Street and Camden Avenue. Second-cycle waste was released to the ground from a ruptured transfer line during transfer of bismuth phosphate waste from the 241-T-107 tank to the 242-T evaporator feed. Readings ranged from 20 to $5,000 \mathrm{mR} /$ hour. Liquid was dispersed over an approximate 22-by440-meter area which was isolated and covered with sand and gravel.

- Unplanned release UN-200-W-63 occurred in September 1966 along $23^{\text {rd }}$ Street at diversion box 241-TX-153. Approximately 1 curie of strontium-90 was released from a used diversion box jumper that was in transit in a truck along the road. Contamination was removed from the road and the area covered with 15 centimeters of soil. 
- Unplanned release UN-200-W-64 occurred in February 1969 along Camden Avenue and $23^{\text {rd }}$ Street. Six hundred counts per minute of cesium-137 were discovered in mud samples in an area cordoned off as a radiation zone. The cause may have been snow melt runoff from nearby radiation zones.

- Unplanned release UN-200-W-97 occurred in May 1966 at the southeast corner of $23^{\text {rd }}$ Street and Camden Avenue south to near $22^{\text {nd }}$ Street. Liquid waste was released from a broken underground line, surfaced, and crossed Camden Avenue but did not run down the side of the road. Surface contamination at 600 counts per minute was detected. Surface contamination was removed to a depth of 0.9 meter.

- Unplanned release UPR-200-W-147 occurred in 1973 at the southeast side of single-shell tank 241-T-103. Contamination was encountered while monitoring wells were being drilled to track a tank leak. The leak may have resulted from a failed grout seal in a spare entry line to the tank. The spill was approximately $5 \mathrm{~m}^{3}$.

- Unplanned release UPR-200-W-148 occurred in April 1973 at 7 meters from single-shell tank 241-T-106. This is the well known leak from tank 241-T-106 (Routson et al. 1979; Freeman-Pollard 1994; Serne et al. 2004).

\subsection{Waste Characteristics}

Three basic chemical processing operations were the source of most of the hazardous waste transferred to the T Tank Farm. These were the bismuth phosphate process, the tributyl phosphate process, and the REDOX process. The bismuth phosphate and REDOX processes were chemical separations programs for recovery of plutonium from irradiated reactor fuels. The tributyl phosphate process recovered uranium metal in waste generated by the bismuth phosphate process. Waste from all three processes was made alkaline for storage in the tanks (Anderson 1990).

Table 2.3 lists the specific wastes and volumes transferred to each tank in WMA T. Anderson (1990) gives approximate chemical compositions for the major waste types sent to the T Tank Farm single-shell tanks.

Jones et al. (2000) have recently given estimates for the composition of the leaked fluids from tanks $\mathrm{T}-101, \mathrm{~T}-103$, and T-106. Table 2.4 gives a partial leak inventory from their data.

\subsection{Geology and Hydrogeology}

This section updates the description of the geology beneath the single-shell tanks WMA T with new information from seven wells drilled since 1999. This information assists decisions concerning well location and well construction if new wells are added to the monitoring network. The geologic interpretation is also used to evaluate pathways to groundwater through the vadose zone and groundwater flow properties.

The regional geologic setting of the Pasco Basin and the Hanford Site has been described previously by Delaney et al. (1991), Reidel et al. (2002), Tallman et al. (1979), and Lindsey et al. (1992). Most recently, Williams et al. (2002) have described the geology of the 200 West Area. The reader is referred to these references for descriptions of the regional geology. 
Table 2.3. Tank Contents and Waste Received for the T Tank Farm Single-Shell Tanks (Agnew et al. 1997)

\begin{tabular}{|c|c|}
\hline Tank & Source Description/Waste Type ${ }^{(\mathrm{a})}$ \\
\hline $241-\mathrm{T}-101$ & $\begin{array}{l}\text { Bismuth phosphate metal waste, tributyl phosphate waste, cladding waste from bismuth } \\
\text { phosphate, cladding waste from REDOX, B Plant HLW, ion exchange from cesium recovery, } \\
\text { evaporator bottoms, REDOX ion exchange, REDOX HLW, B Plant LLW, decontamination } \\
\text { waste, Battelle Northwest Laboratory waste, } 224 \text { waste (lanthanium fluoride finishing waste), } \\
\text { non-complexed waste }\end{array}$ \\
\hline 241-T-102 & $\begin{array}{l}\text { Bismuth phosphate metal waste, cladding waste from bismuth phosphate, B Plant LLW, ion } \\
\text { exchange waste, evaporator bottoms, REDOX ion exchange, REDOX HLW, non-complexed } \\
\text { waste }\end{array}$ \\
\hline $241-\mathrm{T}-103$ & $\begin{array}{l}\text { Bismuth phosphate metal waste, cladding waste, B Plant LLW, ion exchange from cesium } \\
\text { recovery, evaporator bottoms, REDOX ion exchange, REDOX HLW, non-complexed waste }\end{array}$ \\
\hline 241-T-104 & First cycle decontamination waste from bismuth phosphate process, non-complexed waste \\
\hline 241-T-105 & $\begin{array}{l}\text { First and second cycle waste from bismuth phosphate process, REDOX cladding waste, cladding } \\
\text { waste, Hanford laboratory operations waste, decontamination waste, B Plant LLW, ion exchange } \\
\text { waste from cesium recovery, decontamination waste and B Plant ion exchange, non-complexed } \\
\text { waste }\end{array}$ \\
\hline $241-\mathrm{T}-106$ & $\begin{array}{l}\text { First and second cycle waste from bismuth phosphate process, cladding waste, B Plant LLW, ion } \\
\text { exchange waste from cesium recovery, decontamination waste, non-complexed waste }\end{array}$ \\
\hline $241-\mathrm{T}-107$ & $\begin{array}{l}\text { First cycle waste from bismuth phosphate process, tributyl phosphate waste from uranium } \\
\text { recovery, cladding waste, B Plant LLW, ion exchange waste from cesium recovery, evaporator } \\
\text { feed, non-complexed waste }\end{array}$ \\
\hline 241-T-108 & $\begin{array}{l}\text { First cycle waste from bismuth phosphate process, tributyl phosphate waste from uranium } \\
\text { recovery, evaporator bottoms, Hanford laboratory operations waste, Battelle Northwest } \\
\text { laboratory waste, ion exchange waste from cesium recovery, B Plant low level ion exchange, non- } \\
\text { complexed waste }\end{array}$ \\
\hline 241-T-109 & $\begin{array}{l}\text { First cycle waste from bismuth phosphate process, tributyl phosphate waste from uranium } \\
\text { recovery, evaporator bottoms, B Plant LLW, ion exchange waste from cesium recovery, Battelle } \\
\text { Northwest Laboratory waste, non-complexed waste }\end{array}$ \\
\hline 241-T-110 & $\begin{array}{l}\text { Second cycle waste from bismuth phosphate process, lanthanium fluoride finishing waste, non- } \\
\text { complexed waste }\end{array}$ \\
\hline 241-T-111 & $\begin{array}{l}\text { Second cycle waste from bismuth phosphate process, lanthanium fluoride finishing waste, non- } \\
\text { complexed waste }\end{array}$ \\
\hline 241-T-112 & $\begin{array}{l}\text { Second cycle waste from bismuth phosphate process, lanthanium fluoride finishing waste, } \\
\text { decontamination waste, cladding waste, B Plant LLW, ion exchange waste from cesium recovery, } \\
\text { evaporator feed, non-complexed waste }\end{array}$ \\
\hline 241-T-201 & Lanthanium fluoride finishing waste, evaporator feed, non-complexed waste \\
\hline $241-\mathrm{T}-202$ & Lanthanium fluoride finishing waste, non-complexed waste \\
\hline 241-T-203 & Lanthanium fluoride finishing waste, evaporator feed, non-complexed waste \\
\hline $241-\mathrm{T}-204$ & Lanthanium fluoride finishing waste, non-complexed waste \\
\hline \multicolumn{2}{|c|}{$\begin{array}{l}\text { (a) Does not include between tank transfers. } \\
\text { HLW } \quad=\text { High-level waste. } \\
\text { LLW }=\text { Low-level waste. } \\
\text { REDOX }=\text { Reduction/oxidation. }\end{array}$} \\
\hline
\end{tabular}


Table 2.4. Partial Inventory Estimates for Tank Leak Fluids from Tanks in Waste Management Area T (data from Jones et al. 2000)

\begin{tabular}{||l|c|c|c||}
\hline \multicolumn{1}{|c|}{$\begin{array}{c}\text { Element or } \\
\text { Radionuclide }^{(a)}\end{array}$} & Concentration (mol/L for elements or Ci/L for radionuclides) \\
\hline \hline Sodium & T-101 & T-103 & T-106 \\
\hline Chromium & 3.04 & 4.00 & 4.34 \\
\hline Calcium & 0.0122 & $3.91 \mathrm{E}-2$ & $4.27 \mathrm{E}-2$ \\
\hline Nitrate & 0.00789 & $7.73 \mathrm{E}-3$ & $9.16 \mathrm{E}-3$ \\
\hline Nitrite & 0.925 & 1.13 & 1.25 \\
\hline Sulfate & 0.925 & $7.9 \mathrm{E}-1$ & $8.36 \mathrm{E}-1$ \\
\hline Fluoride & 0.0142 & $7.99 \mathrm{E}-2$ & $8.89 \mathrm{E}-2$ \\
\hline Uranium & 0.000353 & $2.9 \mathrm{E}-3$ & $5.43 \mathrm{E}-3$ \\
\hline Tritium & 0.0035 & $2.78 \mathrm{E}-3$ & $3.01 \mathrm{E}-3$ \\
\hline Cobalt-60 & 0.0000236 & $1.03 \mathrm{E}-4$ & $1.08 \mathrm{E}-4$ \\
\hline Strontium-90 & 0.00000114 & $2.06 \mathrm{E}-5$ & $2.25 \mathrm{E}-5$ \\
\hline Technetium-99 & 0.00603 & $4.5 \mathrm{E}-2$ & $4.97 \mathrm{E}-2$ \\
\hline Ruthenium-106 & 0.0000101 & $1.27 \mathrm{E}-4$ & $1.38 \mathrm{E}-4$ \\
\hline Iodine-129 & $2.61 \mathrm{E}-10$ & $3.47 \mathrm{E}-9$ & $3.78 \mathrm{E}-9$ \\
\hline Cesium-137 & $1.91 \mathrm{E}-8$ & $2.45 \mathrm{E}-7$ & $2.66 \mathrm{E}-7$ \\
\hline (a) Radionuclides are decayed to January $1,1994$. & $4.6 \mathrm{E}-2$ & $4.84 \mathrm{E}-2$ \\
\hline \hline
\end{tabular}

The geology specific to WMA T was first described by Price and Fecht (1976) and then by Caggiano and Goodwin (1991). More recently the WMA T geology was summarized by Lindsey and Reynolds (1998) and by Wood et al. (2001). Most recently, Reidel et al. (2005) updated previous work to include observations from four new downgradient and one new upgradient wells at the WMA. Their geologic description is comparable to recent, regional studies (Williams et al. 2002; Wood et al. 2001) and assures coherence within the larger framework of stratigraphic interpretations of the Hanford Site. Any small differences that exist between the geologic description given in Reidel et al. (2005) and descriptions in previous reports result primarily from differences in survey elevations used to interpret lithologic contacts. These are small differences and do not represent any major change or discrepancy. The geologic description give below is summarized from Reidel et al. (2005).

Figure 2.1 shows the locations of all wells in the vicinity of WMA T that were used for geologic interpretation. The quality of data obtained from these wells varies and is a function of when they were drilled, drilling methods, and their purpose. Pertinent information about the wells is given in Appendix C. In general, data from RCRA standard boreholes is of higher quality than data from the older (pre-1989) boreholes. 


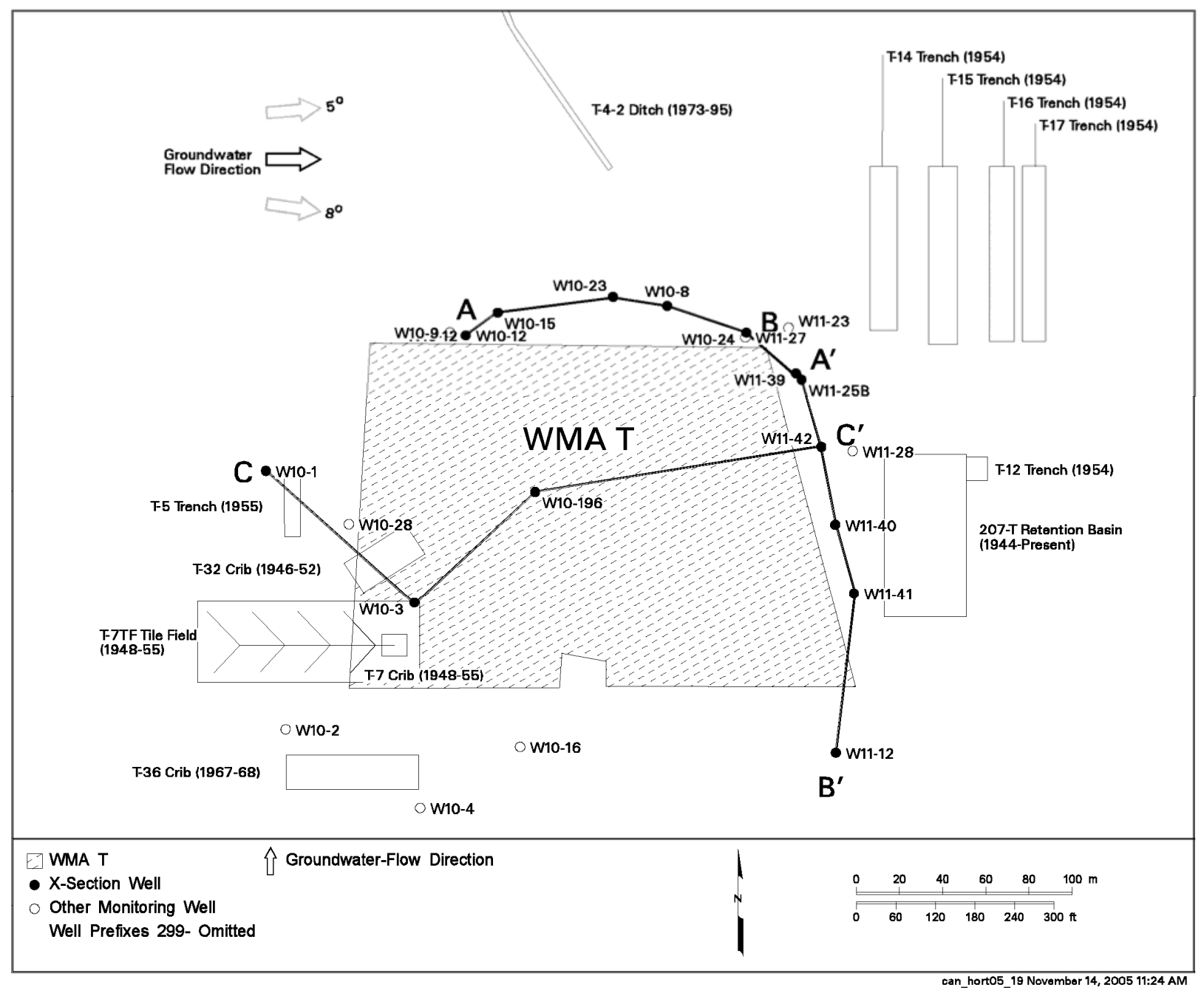

Figure 2.1. The Locations of Wells and Cross-Section at Waste Management Area $T$

Geologic interpretations were made from the well-site geologist's (or driller's) logs. Geophysical logs, particle size distributions, and laboratory moisture data were then compared with the lithologic logs. In some cases, geophysical logs (e.g., gross gamma-ray) allowed refinement of the data by permitting more precise placement of geologic contacts than when lithologic logs alone were used. This was particularly true for wells where only older, driller's logs and no geologist's logs were available.

\subsubsection{Stratigraphy and Lithology at Waste Management Area T}

The vadose zone beneath WMA T is between about 68 and 74 meters thick and consists of the Hanford formation, the Cold Creek unit, the Taylor Flats member of the Ringold Formation, and the upper part of unit $\mathrm{E}$ of the Wooded Island member of the Ringold Formation. The water table is at about 136.5 meters elevation and the unconfined aquifer beneath WMA T is estimated to be about 53 meters thick based on March 2004 water levels and the depth of the Ringold Formation lower mud unit in well 299-W10-24. 
The geology beneath WMA T consists of basalt basement overlain by nine sedimentary sequences distinguished mainly by texture (particle size), mineralogy, responses to natural gamma logs, and stratigraphic position. These sequences are (from top to bottom):

- Holocene eolian sediments and/or backfill material

- Hanford formation gravel-dominated sequence

- Hanford formation sand-dominated sequence

- Cold Creek unit silts and sands

- Cold Creek unit calcic paleosols

- Ringold Formation, member of Taylor Flats

- Ringold Formation, member of Wooded Island unit E

- Ringold Formation, member of Wooded Island lower mud

- Ringold Formation, member of Wooded Island unit A

Figure 2.2 shows a generalized stratigraphic column for the WMA T area. The site specific stratigraphic information used to construct geologic cross-sections, thickness maps and structure contour maps at WMA T is given in Appendix B. The cross-sections are shown in Figures 2.3 through 2.5. (See Figure 2.1 for locations of cross-sections).

The Elephant Mountain Member of the Saddle Mountains Basalt is the base of the suprabasalt aquifers in the area. The Elephant Mountain Member was not encountered in any boreholes in the WMA T area. Based on driller's logs from nearby deep well 299-W11-26, located about 130 meters southeast of the T Tank Farm, the elevation of the top of the Elephant Mountain Member is at about 60 meters above sea level. The Elephant Mountain Member dips gently to the southwest into the Cold Creek syncline.

The Ringold Formation, member of Wooded Island unit A overlies the Elephant Mountain Member beneath WMA T. Unit A is described on borehole logs of cuttings and samples from wells near the WMA T area as pebble to cobble gravel with up to $15 \%$ sand and very little silt. Some interstratified sand horizons exist within the gravel and there are some highly cemented zones. Unit A was completely penetrated in only one borehole in the area of WMA T (well 299-W11-26) where it was found to be 23 meters thick.

The Ringold Formation, member of Wooded Island lower mud unit overlies unit A. The lower contact of the lower mud unit is usually sharp and easy to distinguish from drill cuttings and natural gamma logs. The lower mud unit is described as laminated to massive clay, silt, and sandy silt. Sediments in the lower mud unit are consolidated and generally contain no calcium carbonate. The lower mud unit was completely penetrated in two wells near WMA T; well 299-W10-24 where it was found to be 1.25 meters thick and well 299-W11-26 where it was found to be 5.2 meters thick.

The lower mud unit is equivalent to hydrogeologic unit 8 of Williams et al. (2002). They describe hydrogeologic unit 8 as separating the suprabasalt aquifer into an upper unconfined aquifer in the sediments above the lower mud unit and a lower, confined aquifer in the Ringold Formation unit A. Groundwater in the unconfined aquifer and the confined Ringold Formation unit A aquifer does not flow vertically through hydrogeologic unit 8 (Williams et al. 2002). 


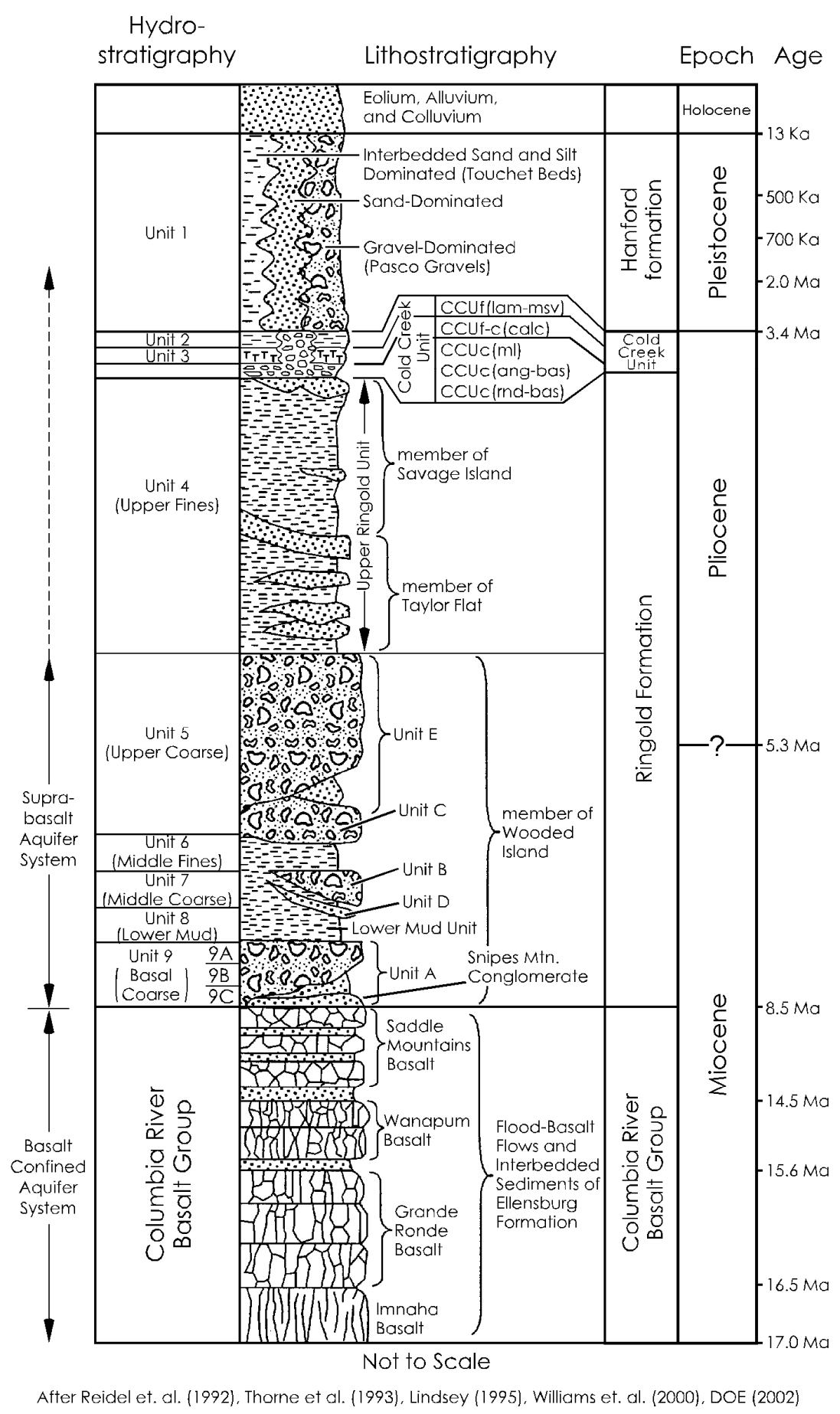

2004/DCL/TX-TY/004 (03/23)

Figure 2.2. Generalized Stratigraphic Column for the Hanford Site (modified from Lindsey 1996). The column is not to scale. The member of Savage Island, the member of Wooded Island units C, B, and D, and the Snipes Mountain Conglomerate are not present at Waste Management Area $\mathrm{T}$. 


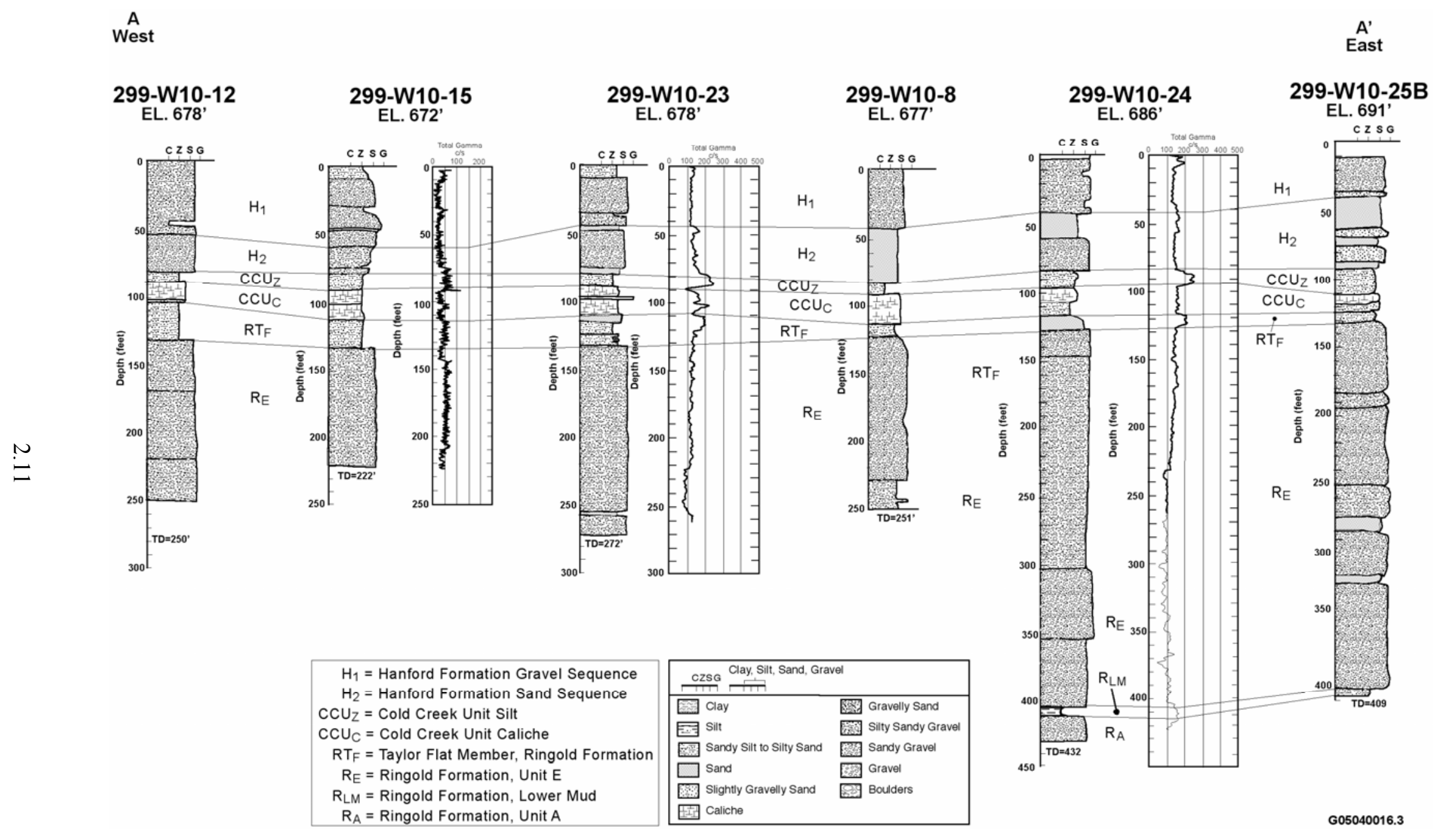

Figure 2.3. Cross-Section of the Geology North of Waste Management Area T (See Figure 2.1 for the location of the cross-section; multiply feet by 0.3048 to change to meters.) 


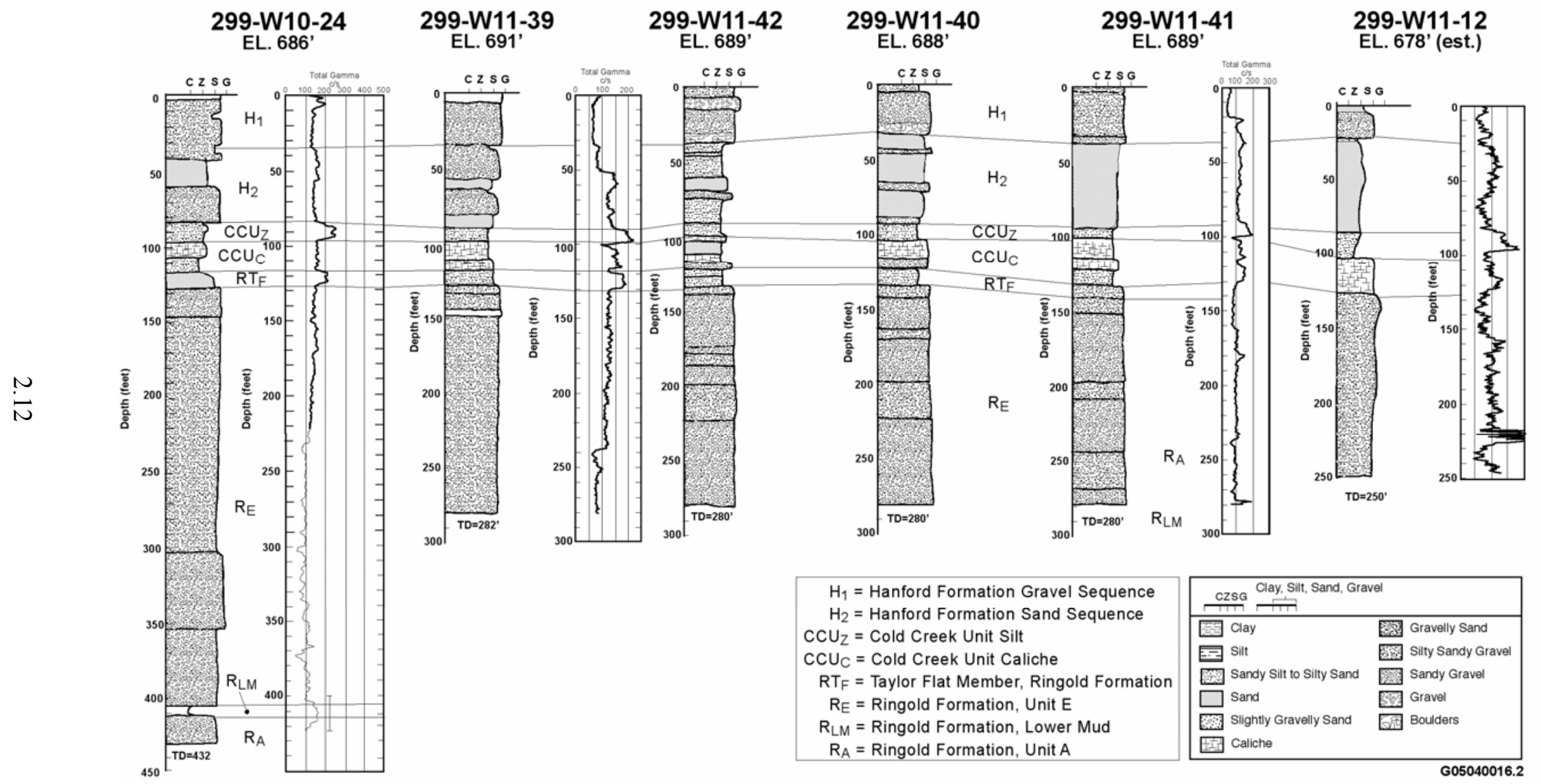

Figure 2.4. Cross-Section of the Geology East (downgradient) of Waste Management Area T (See Figure 2.1 for the location of the crosssection; multiply feet by 0.3048 to change to meters.) 


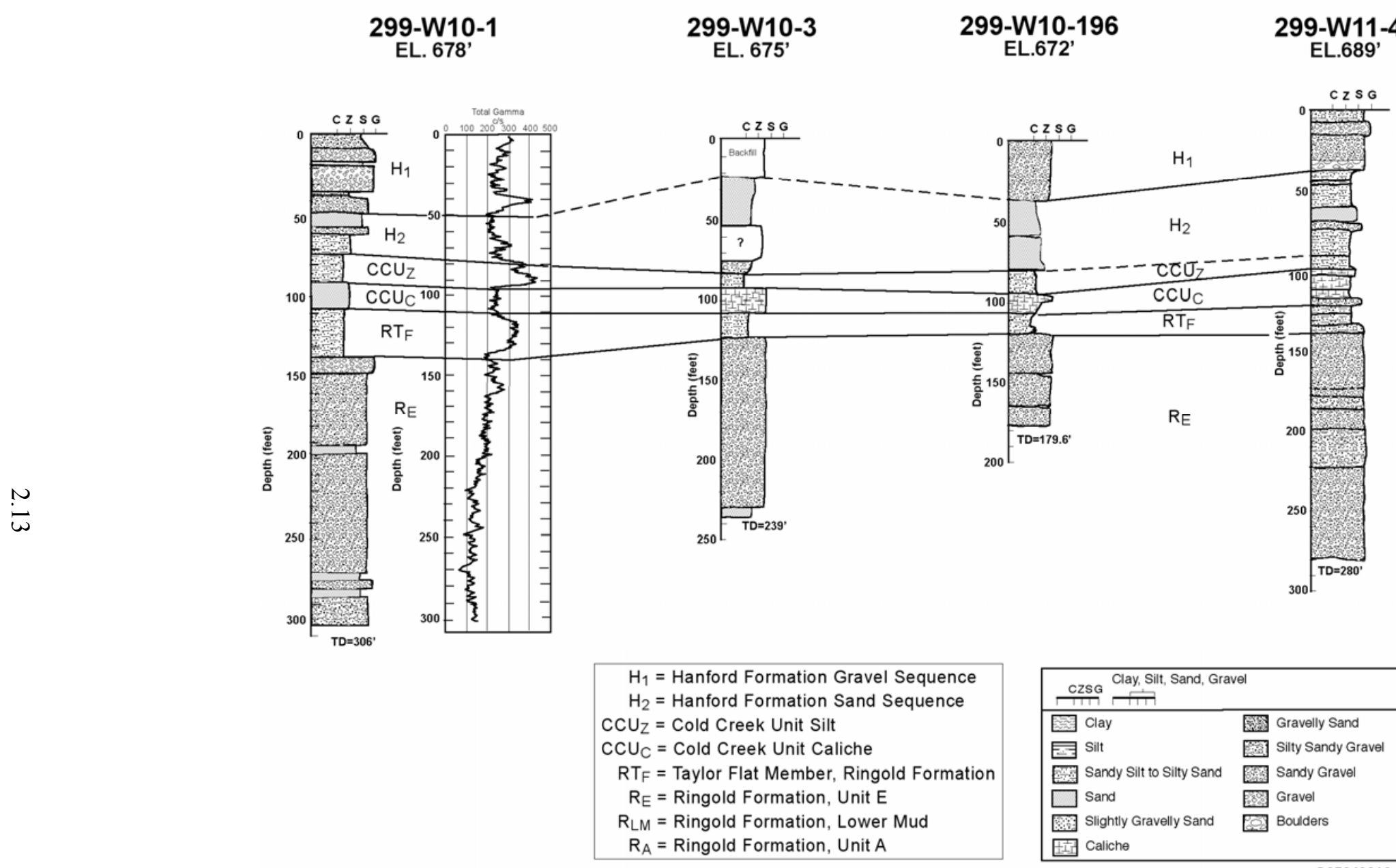

299-W10-196
EL 672'

299-W11-42

99-W10-1

9-W10-3

E.672

EL.689'

Formation Gravel Sequence 列

$U_{C}=$ Cold Creek Unit Caliche

$R_{E}=$ Ringold Formation, Unit $E$

$\mathrm{R}_{\mathrm{A}}=$ Ringold Formation, Unit $\mathrm{A}$

\begin{tabular}{|c|c|}
\hline \multicolumn{2}{|c|}{ CzsG Clay, Silt, Sand, Gravel } \\
\hline 國 Clay & 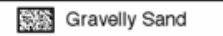 \\
\hline Silt & Silty Sandy Gravel \\
\hline Sandy Silt to Silty Sand & Sandy Gravel \\
\hline$\square$ Sand & 罝 Gravel \\
\hline $\begin{array}{l}\text { 國 Slightly Gravelly Sand } \\
\text { 四 Caliche }\end{array}$ & Boulders \\
\hline
\end{tabular}

Figure 2.5. Cross-Section of the Geology Beneath Waste Management Area T (See Figure 2.1 for the location of the cross-section; multiply feet by 0.3048 to change to meters.) 
Where the lower mud unit is not present, the suprabasalt aquifer is a single system. The limited data available from the WMA T area suggests that the lower mud unit extends laterally beneath the entire WMA.

Overlying the lower mud unit is the Ringold Formation, member of Wooded Island unit E. The contact between the two is easily distinguished on natural gamma logs by a considerable drop in gamma activity in going from the lower mud unit into unit $\mathrm{E}$. Unit $\mathrm{E}$ is described on borehole logs of cuttings and samples from wells near the WMA T area as a pebble to cobble gravel with a fine- to coarse-grained sand matrix. Gravel content is usually greater than 60 to $70 \%$. Occasionally, what are interpreted as large boulders are encountered during drilling. The sediments are variably consolidated, usually poorly sorted and show variable amounts of calcium carbonate. Iron oxide staining is common. "Slow drilling," "hard drilling," and "switched to hard tool" are common comments on the geologists' logs when drilling in unit E sediments.

Unit E was fully penetrated by three wells in the WMA T area: well 299-W10-24 where it was found to be 86 meters thick, 299-W11-26 where it was 83 meters thick, and well 299-W11-25B where it was 84 meters thick. Many wells in the WMA T area penetrate the top of unit E. Based on the elevation of the upper boundary of unit E, the unit dips slightly toward the west or southwest beneath WMA T (Figure 2.6).

Unit E is overlain by bedded sandy silt, sand, and silty sand of the Ringold Formation, member of Taylor Flats. These sediments are unconsolidated to consolidated and poorly to well sorted. Local pebbly areas occur. In places, calcium carbonate occurs as stingers and nodules whereas in other places no calcium carbonate exists. The lower boundary of the member of Taylor Flats is easily recognized by the difference in texture between this fine-grained member and the underlying unit E gravels.

The member of Taylor Flats ranges in thickness from 1.2 to 10.3 meters beneath WMA T, but is generally thicker than 3 meters, and averages 5.5 meters (Figure 2.7). Like the underlying units, the member of Taylor Flats has a general, gentle dip toward the southwest (Figure 2.6).

The Cold Creek unit calcic paleosol sequence (formerly known as the Plio-Pleistocene caliche) overlies the member of Taylor Flats. The contact between the two is marked by a substantial increase in calcium carbonate in the paleosol sequence and a substantial decrease in the natural gamma log going from the underlying sands and silts into the paleosol sequence. The Cold Creek paleosol sequence consists of calcium carbonate-cemented silt, silty sand, and sandy silt with some gravel in places. In most wells the calcium carbonate is fairly continuous throughout the unit, but in others there are calicherich and caliche-poor zones. In one well (299-W11-38), three distinct caliche zones were recognized. In places, the sediment becomes extremely cemented with calcium carbonate so that the driller changes from drive barrel to hard tool in order to continue drilling.

The Cold Creek unit calcic paleosol sequence occurs in all wells at WMA T. The sequence ranges in thickness from 2.4 to 9.8 meters with an average thickness of 5.3 meters under the WMA. 


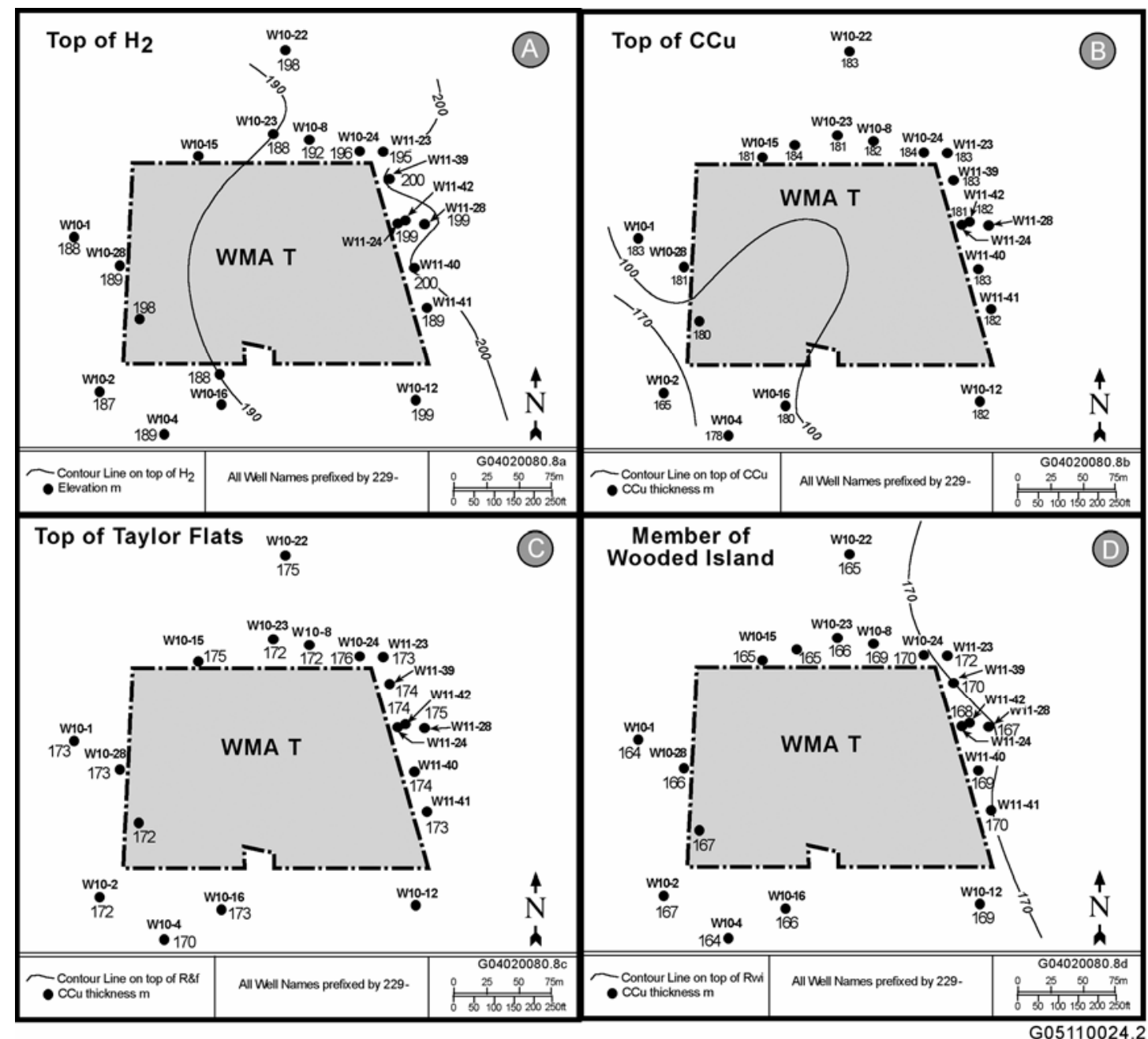

Figure 2.6. Structure Contour Maps for Selected Units Under Waste Management Area T (from Reidel et al. 2005)

Cold Creek unit fluvial and/or eolian sediments overlie the calcic paleosol sequence at WMA T. These sediments are slightly to well consolidated, moderately to well sorted silt and sandy silt. They may contain calcium carbonate but lack the extensive cementation found in the underlying calcic paleosols.

The driller's log for well 299-W10-2, located about 35 meters southwest of T Tank Farm, noted perched water from 26 to 31 meters depth. This closely corresponds to the top and bottom of the Cold Creek fluvial and eolian sequence in the well. Perched water also was found just above the contact of the Cold Creek fluvial sediments and the overlying Hanford formation in well 299-W10-22, north of the WMA. Although perched water has not been found beneath the WMA, the Cold Creed fluvial sediments extend throughout the area so that perched water may occur locally in areas that have not been drilled.

The Cold Creek fluvial and/or eolian sequence is between 1.8 and 6.7 meters in thickness and averages 3.6 meters thick at WMA T (Figure 2.7). The surface of the unit dips gently to the southwest (Figure 2.6). 


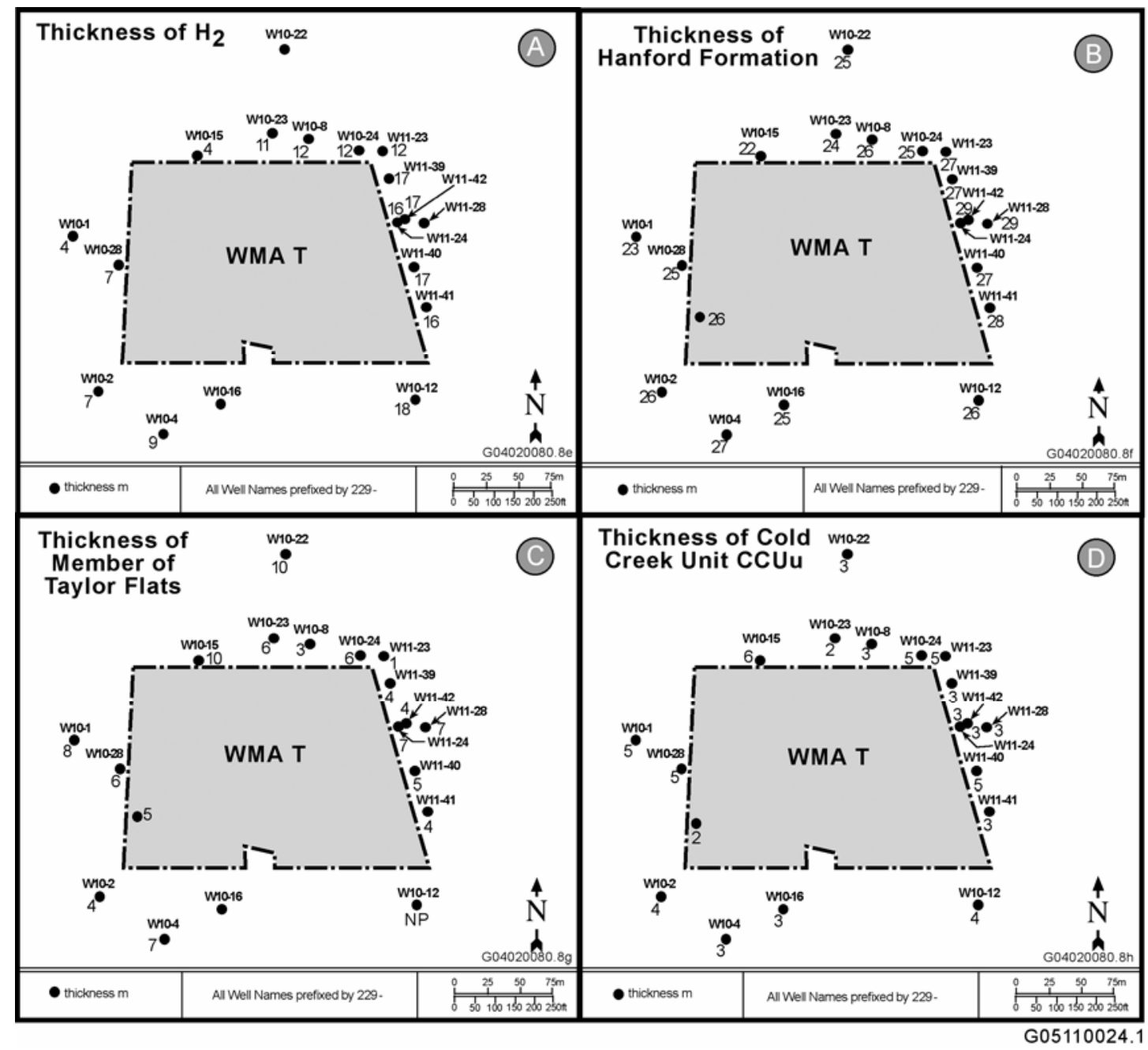

Figure 2.7. Thickness Maps for Selected Units Under Waste Management Area T (from Reidel et al. 2005)

A Hanford formation sand-dominated sequence overlies the Cold Creek fluvial sediments beneath WMA T. The sequence is equivalent to the sandy sequence of Lindsey et al. (1992), the Hanford formation H2 sequence of Lindsey et al. (1994), and to Qfs of Reidel and Fecht (1994).

The Hanford formation sand-dominated sequence (H2) is described on borehole logs of cuttings in the WMA T area as variably bedded silty sand, sand, and slightly gravelly to gravelly sand. The sediments are poorly to well sorted and unconsolidated. Fine-grained, silt-rich lenses are common and range from about 5 to 10 centimeters up to about 30 centimeters in thickness. Based on observations of outcrop and intact core, the sand-dominated sequence is interpreted to have been deposited during the waning stages of glacial flooding.

The Hanford formation sand sequence ranges from about 4 to 18 meters and averages 13 meters in thickness beneath the WMA (Figure 2.7). The sandy beds are "salt and pepper" sands ranging from about $30 \%$ basaltic and $70 \%$ felsic sand to $70 \%$ basaltic and $30 \%$ felsic sand. The sequence is not cemented but does contain zones with calcium carbonate as small concretions and as coatings on grains. 
Thin silt lenses cap some individual beds within the Hanford formation sand-dominated sequence. These lenses are generally 15 centimeters or less in thickness but range up to about 30 centimeters thick. Generally, the silt lenses cannot be correlated among boreholes. However, one thin silt lens can be traced among three boreholes along the north edge of the WMA (Figure 2.3).

The base of the Hanford formation sand-dominated sequence is recognized by a change from the finer-grained silty sand to coarser grained deposits and is reflected by a decrease in natural gamma activity when going upward from the sediments of the Cold Creek unit into the Hanford formation. The top of the sand-dominated sequence is more difficult to distinguish and is usually chosen at the top of the shallowest sand bed that is greater than 3 meters thick, beneath gravel-dominated deposits. In some wells, this corresponds to a decrease in natural gamma activity when going from the sand-dominated sequence upward into the gravel-dominated sequence. The Hanford formation sand-dominated sequence tends to be thicker beneath the eastern part of the WMA (Figure 2.7) and has a slight dip toward the west or southwest (Figure 2.6).

A Hanford formation gravel-dominated sequence overlies the sand-dominated sequence. The graveldominated sequence is described on borehole logs of cuttings as consisting of silty sandy gravel and sandy gravel with some interbedded sand and silty sand. This sequence is equivalent to the Hanford formation upper gravel sequence of Lindsey et al. (1992), the Hanford formation H1 sequence of Lindsey et al. (1994), and Qfg of Reidel and Fecht (1994). Caggiano and Goodwin (1991), in the original groundwater monitoring plan for single-shell tanks, did not differentiate this sequence and the underlying Hanford formation sand-dominated sequence. The upper gravel-dominated sequence was deposited by high-energy, glacial flood waters.

The Hanford formation gravel-dominated sequence varies from 6 to 17 meters thick in the WMA T area and averages about 11 meters thick. Much or the entire unit was removed from most, if not all, of the tank farm during construction and replaced as backfill after construction was complete. The base of the gravel-dominated sequence was chosen at the top of the first sand or silty sand sequence that is at least 3 meters thick. This contact may be somewhat arbitrary, particularly in boreholes with only a driller's log and no natural gamma log.

Holocene deposits overly the Hanford formation at WMA T. These deposits are limited to wind blown silt and sand. Eolian sheet sands occur sporadically at the surface and generally are less than 1 to 2 meters thick. Eolian sediments do not occur in the tank farm where they were removed during construction. Backfill material occurs to about 15 meters depth in the tank farm. The backfill is poorly sorted, gravelly sand to sandy gravel (Price and Fecht 1976) from the gravel-dominated sequence of the Hanford formation.

Price and Fecht (1976) state that clastic dikes were detected in the T Tank Farm during construction although they could not be mapped. Clastic dikes have not been recognized during drilling of the RCRA wells at WMA T although they have been identified in recent wells drilled at WMA TX-TY and WMA S-SX. 


\subsubsection{Aquifer Properties}

This section provides information on the properties of the unconfined aquifer in the immediate region of WMA T. Aquifer properties were determined from stratigraphic interpretations, current water level elevations, and aquifer testing. Most of the information given in this section is summarized from Serne et al. (2004) and Reidel et al. (2005).

Currently, the water table at WMA T is at about 136.5 meters above sea level. The suprabasalt aquifer system beneath WMA T is estimated to be about 80 meters thick based on the depth to top of basalt in well 299-W11-26, located about 130 meters southeast of the WMA. The suprabasalt aquifer system consists of the Ringold confined aquifer, which is about 28 meters thick and lies between the top of basalt and the bottom of the lower mud unit, and the unconfined aquifer, which is about 52 meters thick and lies above the lower mud unit. All wells in the WMA T monitoring network are screened in the unconfined aquifer, hydrogeologic unit 5 of Williams et al. (2002) (the Ringold Formation unit E).

Water levels in the unconfined aquifer were raised as much as 13.5 meters (above the pre-Hanford Site natural water table) beneath WMA T because of artificial recharge from liquid waste disposal operations active between the mid 1940s and 1995. The largest volumes of discharge were to the 216-T pond system and the $216-\mathrm{U}-10$ pond system.

Figure 2.8 shows the groundwater elevations in the north part of 200 West Area since the late 1940s. The figure shows that the increase in water-table elevation was most rapid from 1949 to 1956 and was somewhat stable between the late 1960s and the late 1980s. Water levels began to decline in the late 1980s beneath WMA T when wastewater discharges in the 200 West Area were reduced. The decline in water levels may have implications for the groundwater monitoring network at the WMA T as will be discussed later.

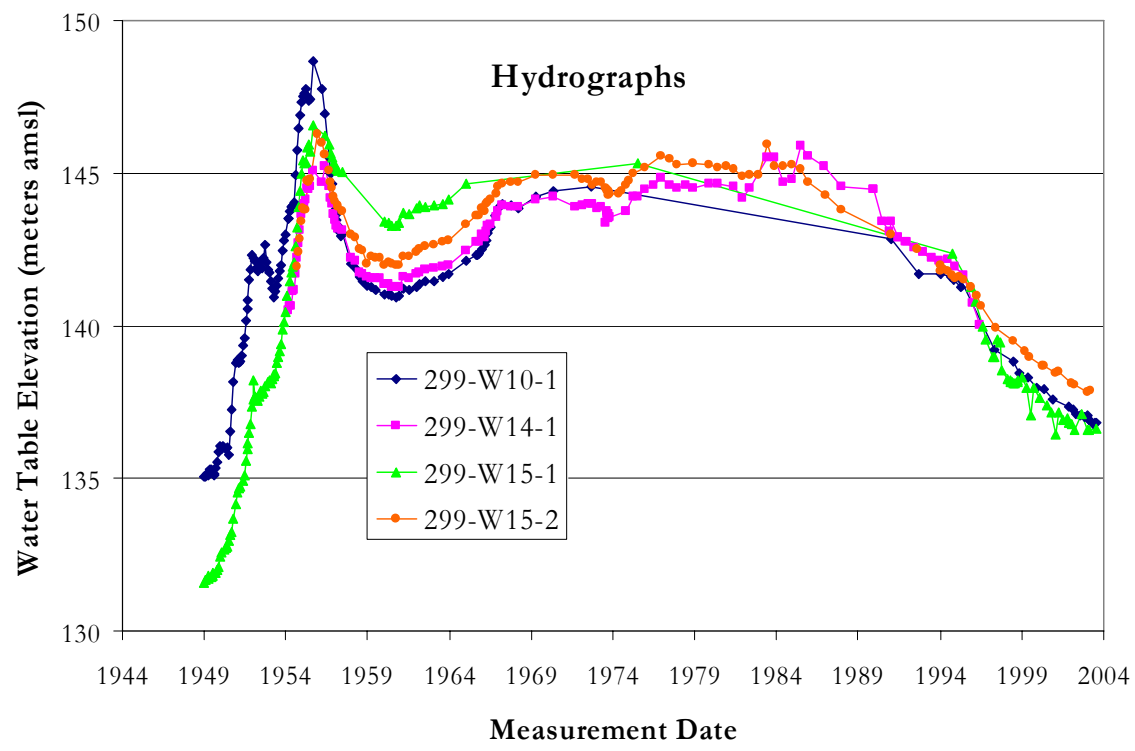

Figure 2.8. Hydrographs of Selected Wells in North 200 West Area 
Accompanying the changes in water level were changes in groundwater flow direction. Histograms (rose diagrams) showing groundwater flow directions beneath the T Tank Farm during different time periods are shown in Figure 2.9. The rose diagrams plot the solutions to numerous three-point analyses using water level information from various well triplets in the north central part of $200 \mathrm{West}$ Area. The petals of the rose diagrams point in the direction of groundwater flow and the length of the petals represent the percentage of measurements showing that groundwater flowed in the indicated direction. It should be noted that the apparent abrupt shifts in groundwater flow directions did not occur. Instead, the large changes in flow directions most likely took place over a period of months.

Pre-Hanford Site (circa 1942) groundwater flow direction was toward the east (Kipp and Mudd 1974). The rose diagram in Figure 2.9A shows that groundwater flow had changed toward the south in the area by the early 1950s. This shift resulted from disposal of large volumes of liquid to the 216-T pond system, located north of WMA T. In 1956, groundwater flow direction changed again and started flowing towards the northeast due to the increasing influence of the groundwater mound under 216-U pond and a decreasing influence of the mound under 216-T pond (Figure 2.9B). Discharges to 216-T pond ended in 1976 but continued at 216-U pond until 1984. As discharges to the 216-U pond declined in the early 1980s, groundwater flow shifted to a more northward direction as the groundwater mound began to decrease and discharges to the 216-U-14 ditch continued. The slight westward component to the groundwater flow direction between early 1980s and mid 1990s (Figure 2.9C) is probably a result of the discharges to the 216-U-14 ditch, located southwest of WMA T, influencing water levels in some of the wells used in the analysis. All non-permitted discharges to the ground ceased and the influence of the 216-U pond mound on the groundwater beneath the T Tank Farm diminished in 1995. Consequently, the flow direction changed again in about 1996 and began to return toward an eastward direction where it is expected to stabilize (Figure 2.9D).

These large shifts in groundwater flow direction have large implications for contaminant distribution in the uppermost aquifer beneath WMA T. In the late 1940s and early 1950s, contamination was spread south in the aquifer. Then, in the late 1950s and until the mid-1990s that same contamination returned to the north along with any new contamination that entered the aquifer after the 1950s. Today, groundwater contamination beneath WMA T and surrounding area is generally migrating east.

Recently, two trend-surface analyses, done in August and September 2002, yielded groundwater flow directions of $6^{\circ}$ to $8^{\circ}$ south of east and a water-table gradient between of 0.00114 and 0.00132 (Spane et al. 2002). An earlier trend-surface analysis yielded a flow direction of $5^{\circ}$ north of east and a watertable gradient of 0.00172 (Spane et al. 2001). Although the flow direction may differ slightly from well to well due to heterogeneous aquifer sediments, the groundwater flow direction at WMA T as determined by the trend surface analyses is consistent with the current regional groundwater map (Hartman et al. 2005). A current groundwater map for WMA T (and WMA TX-TY) is shown in Figure 2.10.

Borehole tracer dilution and tracer pumpback tests were conducted in three new RCRA monitoring wells at the T Tank Farm between fiscal years 1999 and 2001. These tests permitted some inferences about flow rate and aquifer homogeneity. The tests allowed direct observation of the effect of lateral groundwater flow through the well screens and, thus, provided an indication of the variability of flow through the screened intervals. Details of the test methods, computations, and results are included in Spane et al. (2001 and 2002). 


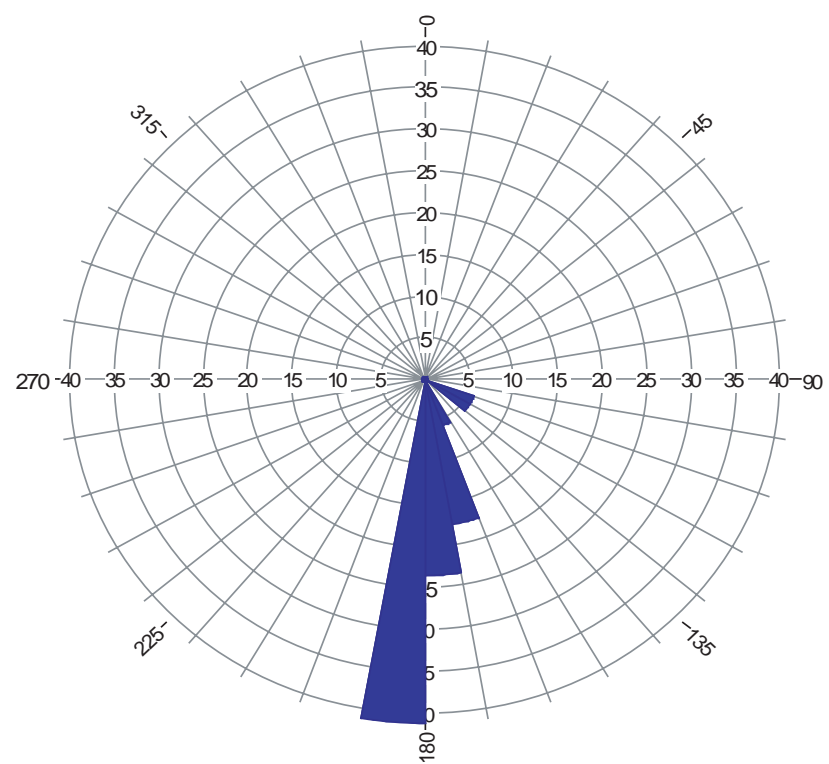

(A) $1954-1956$

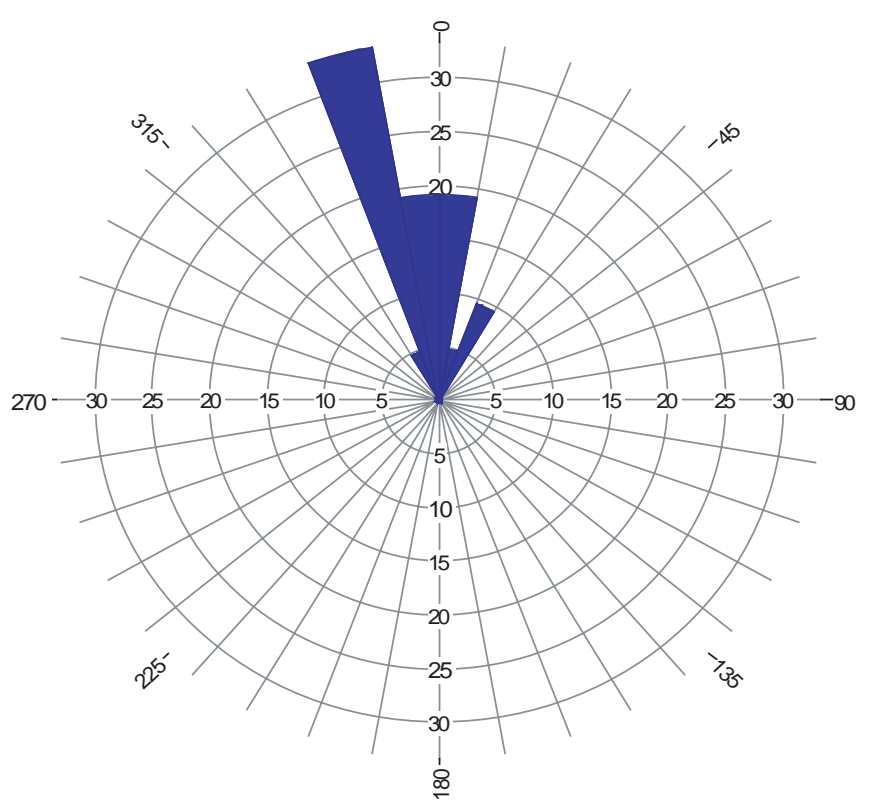

(C) $1983-1995$

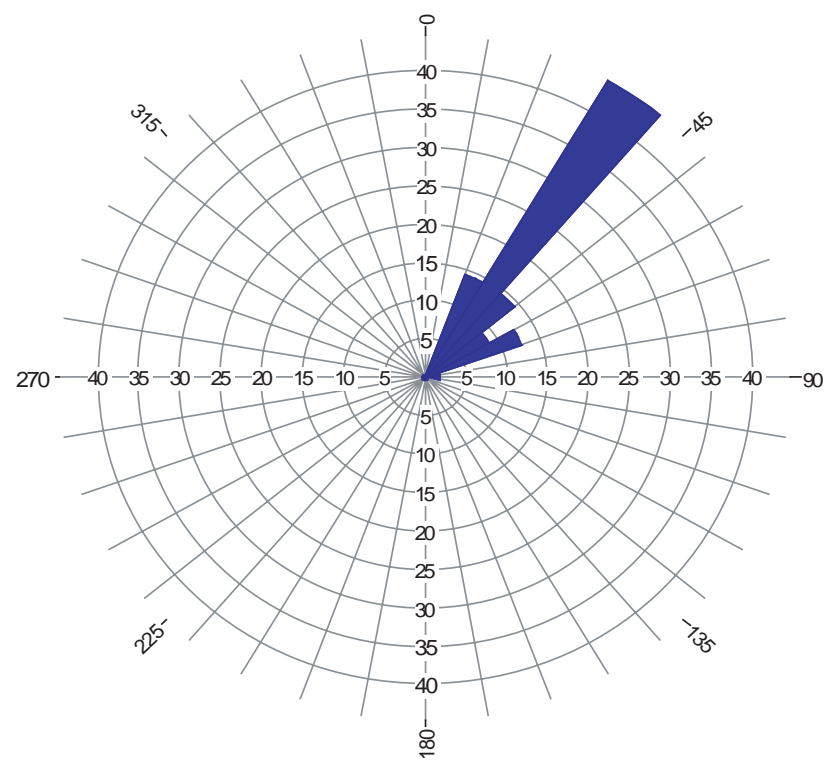

(B) $1957-1982$

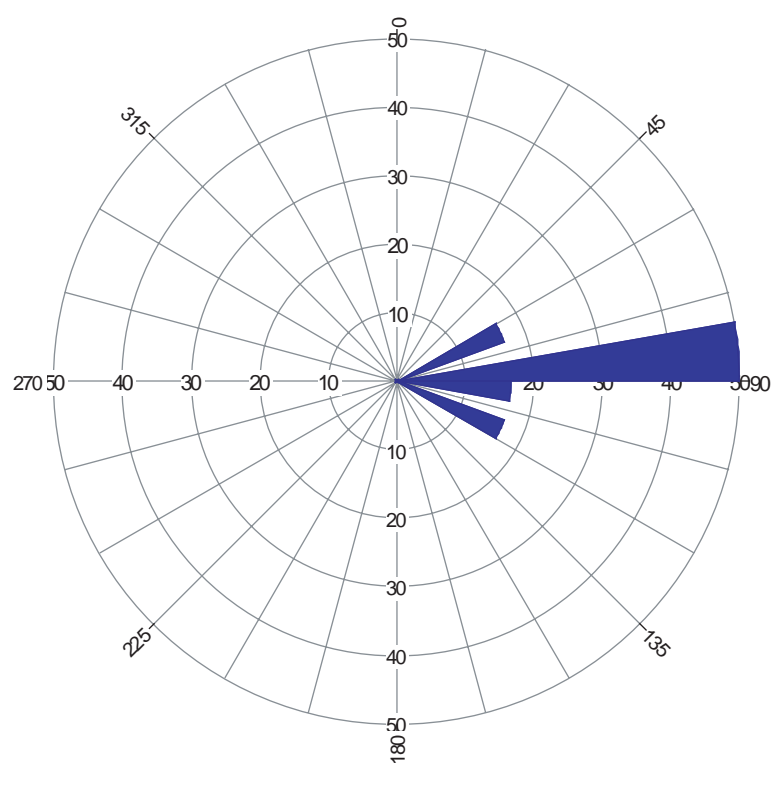

(D) $1997-2003$

Figure 2.9. Groundwater Flow Directions in the North Part of 200 West Area. (A) 1954 to 1956, 1 well triplet, 17 measurements; (B) 1957 to 1982, 2 well triplets, 56 measurements; (C) 1983 to 1995, 4 well triplets, 21 measurements; (D) 1997 to 2003, 3 well triplets, 6 measurements. 


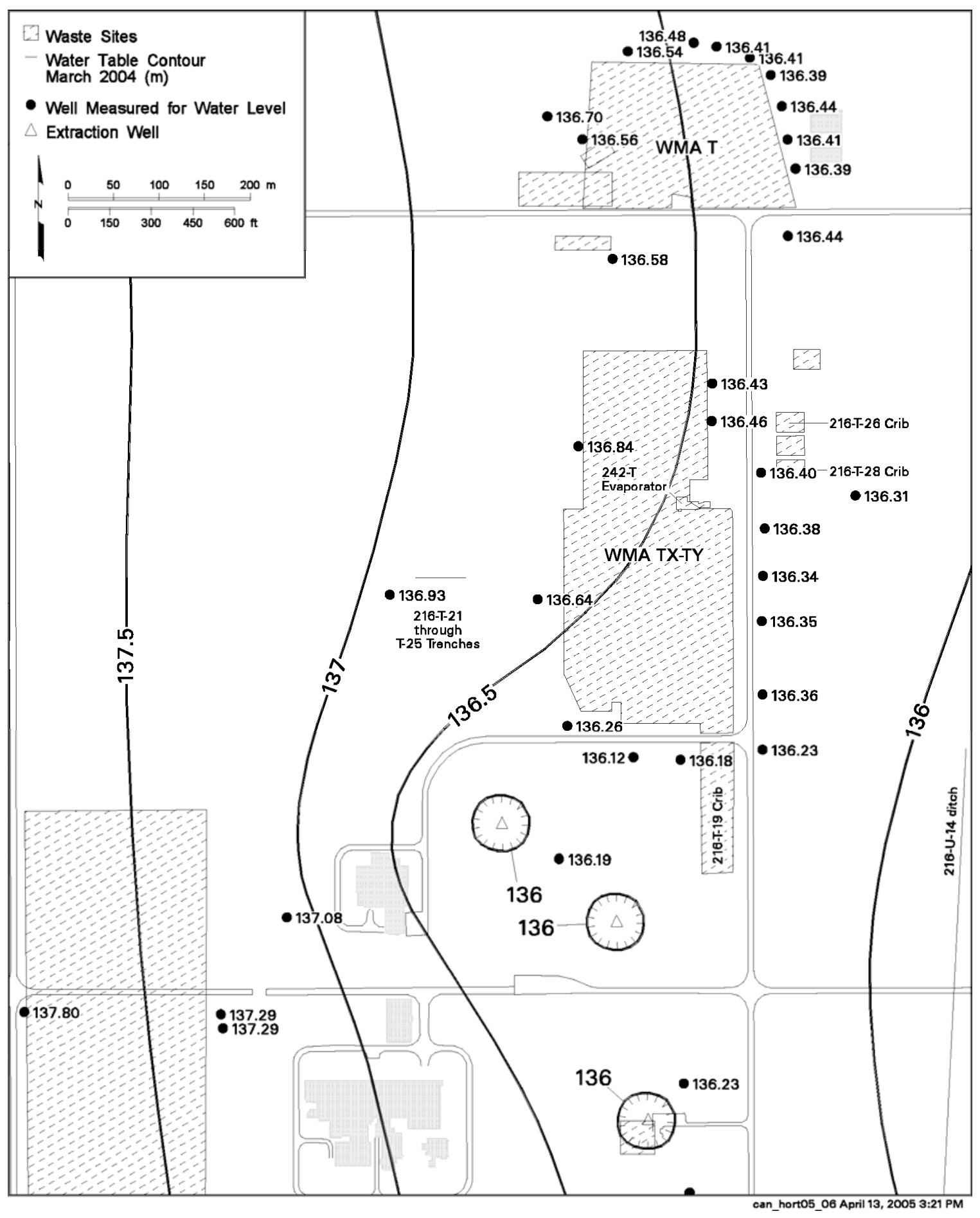

Figure 2.10. March 2004 Water-Table Map for the Area Around Waste Management Area T 
A significant feature of the tracer dilution test results is evidence for downward, vertical hydraulic gradients within the upper portion of the aquifer in wells 299-W11-39 and 299-W11-40. Table 2.5 summarizes the test results for these wells.

Table 2.5. In-Well, Downward Vertical, Flow-Velocity Summary for Wells 299-W11-39 and 299-W11-40 at Waste Management Area T (Spane et al. 2002)

\begin{tabular}{||l|c|c||}
\hline \multirow{2}{*}{\multicolumn{2}{|c|}{ Test Well }} & \multicolumn{2}{|c|}{ Tracer Dilution Profile } \\
\cline { 2 - 3 } & Range $(\mathrm{m} / \mathrm{min})$ & Average $(\mathrm{m} / \mathrm{min})$ \\
\hline \hline 299-W11-39 & $0.0003-0.002$ & 0.001 \\
\hline 299-W11-40 & $0.011-0.020$ & 0.017 \\
\hline \hline
\end{tabular}

The existence of vertical flow in a well does not necessarily reflect actual groundwater flow conditions within the surrounding aquifer, but its presence implies a vertical flow gradient in the well bore and has implications pertaining to how representative the groundwater samples collected from the wells are. Also, the vertical gradient in some wells along the downgradient edge of WMA T may have an impact on contaminant distribution in the aquifer.

A second feature of the hydrologic test data is the suggestion of higher or lower hydraulic conductivity at certain depths within the screened interval of some wells relative to other depths. For example, tracer tests indicate that the upper 3 to 4 meters of the screened interval of well 299-W10-24 is less permeable than the lower part of the screened interval. However, a tracer test in nearby well 299-W11-39 indicated that the lower 1.8 meters of the screened interval are relatively impermeable compared to the rest of the interval. Thus, apparent differences in permeability do not appear to correlate from well to well.

For the WMA T groundwater assessment, new hydraulic conductivity data were obtained from slug tests and drawdown tests conducted in nine new wells drilled since 1999. Effective porosities were determined from tracer drift and tracer pumpback tests. Hydraulic properties are discussed in detail by Spane et al. 2001, 2002; and Spane et al. 2003 and are presented in Tables 2.6 and 2.7.

Table 2.6. Results from Tracer-Dilution and Tracer-Pumpback Tests in Wells at Waste Management Area T (Spane et al. 2001, 2002)

\begin{tabular}{|c|c|c|c|}
\hline Well & Effective Porosity ${ }^{(a)}$ & $\begin{array}{l}\text { Horizontal } \\
\text { Groundwater }^{(\mathrm{a})} \text { Flow } \\
\text { Velocity }(\mathrm{m} / \mathrm{d})\end{array}$ & $\begin{array}{l}\text { Average In-Well } \\
\text { Horizontal Flow } \\
\text { Velocity }^{(b)}\end{array}$ \\
\hline 299-W10-24 & 0.072 & 0.029 & 0.012 \\
\hline $299-W 11-39^{(c)}$ & 0.022 & 0.045 & 0.014 \\
\hline $299-W 11-40^{(\mathrm{d})}$ & 0.002 & 1.1 & 0.176 \\
\hline \multicolumn{4}{|c|}{$\begin{array}{l}\text { (a) Data from tracer pump back tests. } \\
\text { (b) Data from tracer dilution tests. } \\
\text { (c) Slight downward vertical flow, data uncertain. } \\
\text { (d) Strong downward vertical flow, data highly uncertain. }\end{array}$} \\
\hline
\end{tabular}


Table 2.7. Hydraulic Properties from Slug and Constant Rate Pumping Tests and Calculated Horizontal Flow Velocities at New Wells at Waste Management Area T

\begin{tabular}{|c|c|c|c|c|c|}
\hline Well & $\begin{array}{c}\text { Hydraulic }^{(\mathrm{a}, \mathrm{b})} \\
\text { Conductivity }(\mathrm{m} / \mathrm{d})\end{array}$ & $\begin{array}{c}\text { Hydraulic }^{(\mathrm{a}, \mathrm{c})} \\
\text { Conductivity }(\mathrm{m} / \mathrm{d})\end{array}$ & $\begin{array}{l}\text { Transmissivity }^{(\mathrm{a}, \mathrm{c})} \\
\left(\mathrm{m}^{2} / \mathrm{d}\right)\end{array}$ & $\begin{array}{l}\text { Specific }^{(a, c)} \\
\text { Yield }\end{array}$ & $\begin{array}{l}\text { Calculated Flow } \\
\text { Velocity }(\mathrm{m} / \mathrm{d})\end{array}$ \\
\hline 299-W10-23 & $1.62-2.35$ & ND & ND & ND & $0.024^{(\mathrm{e})}$ \\
\hline 299-W10-24 & $1.04-1.68$ & 1.22 & 66 & 0.11 & $0.023^{(f)}$ \\
\hline 299-W10-28 & $27.9^{(\mathrm{g})}$ & ND & ND & ND & $0.23^{(\mathrm{e})}$ \\
\hline 299-W11-39 & $1.31-1.69$ & 0.85 & 44 & 0.1 & $0.017^{(\mathrm{d})}$ \\
\hline 299-W11-40 & $3.56-4.58$ & 2.02 & 103 & 0.1 & $0.046^{(\mathrm{d})}$ \\
\hline 299-W11-41 & $7.57-7.78$ & ND & ND & ND & $0.078^{(\mathrm{e})}$ \\
\hline 299-W11-42 & $28.1^{(\mathrm{g})}$ & ND & ND & ND & $0.28^{(\mathrm{e})}$ \\
\hline
\end{tabular}

(a) Data from Spane et al. 2001a, 2002, and 2003.

(b) Slug test data.

(c) Constant rate pumping test data.

(d) Estimated using maximum hydraulic conductivity value, a gradient of 0.001 , and specific yield from this table. Specific yield was used because downward flow in the well resulted in uncertain effective porosity.

(e) Estimated using maximum hydraulic conductivity value, a gradient of 0.001 and effective porosity values of 0.1 .

(f) Estimated using maximum hydraulic conductivity value, a gradient of 0.001 , and effective porosity value from Table 2.6.

(g) Indicates average hydraulic conductivity obtained from high-permeability, non-linear type-curve analysis method.

$\mathrm{ND}=$ Not determined.

The horizontal groundwater flow velocities determined from tracer pump back tests (Table 2.6) are greater than the calculated velocities (Table 2.7) for wells which have downward vertical flow in the well bore (299-W11-39 and 299-W11-40). The vertical flow in these wells probably resulted in overestimation of the measured flow velocity. Both the measured and calculated velocities are about the same for well 299-W10-24, which has no vertical flow.

Overall, there is about an order of magnitude difference in the horizontal flow velocities in Table 2.7. The horizontal velocity in wells $299-\mathrm{W} 10-28$ and 299-W11-42 are substantially greater than the velocities calculated for the other wells. Very rapid recoveries during slug testing were noted ( $90 \%$ recovery within 4 seconds for both wells), which suggests fairly permeable formations (Spane et al. 2002, 2003). However, there is nothing in the geologist's logs or the geophysical logs to suggest that the formation in the screened interval of these wells is significantly different than the formation at other, nearby wells.

Taken as a whole, the geologist's logs, geophysical logs, development pumping data, and the hydrologic testing data all indicate heterogeneity in the aquifer properties within the screened intervals of several individual wells and among wells at WMA T. No widespread trends have been identified.

The hydrographs in Figure 2.11 show that water levels have declined by about 6.5 meters since 1991 beneath the T Tank Farm. This decline, resulting from decreasing effluent discharge in the 200 West Area, became much steeper in 1995 with the effective cessation of discharge to all non-permitted facilities in this area. Between 1998 and 2004 the average rate of water table decline has been between about 0.3 to 0.4 meter/year in all monitoring wells at WMA T. The rapid decrease in water levels after 1995 has resulted in monitoring wells going dry more quickly than previously predicted and has necessitated the drilling of seven new monitoring wells since 1999. The life expectancy for all wells in the WMA T monitoring network is shown in Table 2.8. 


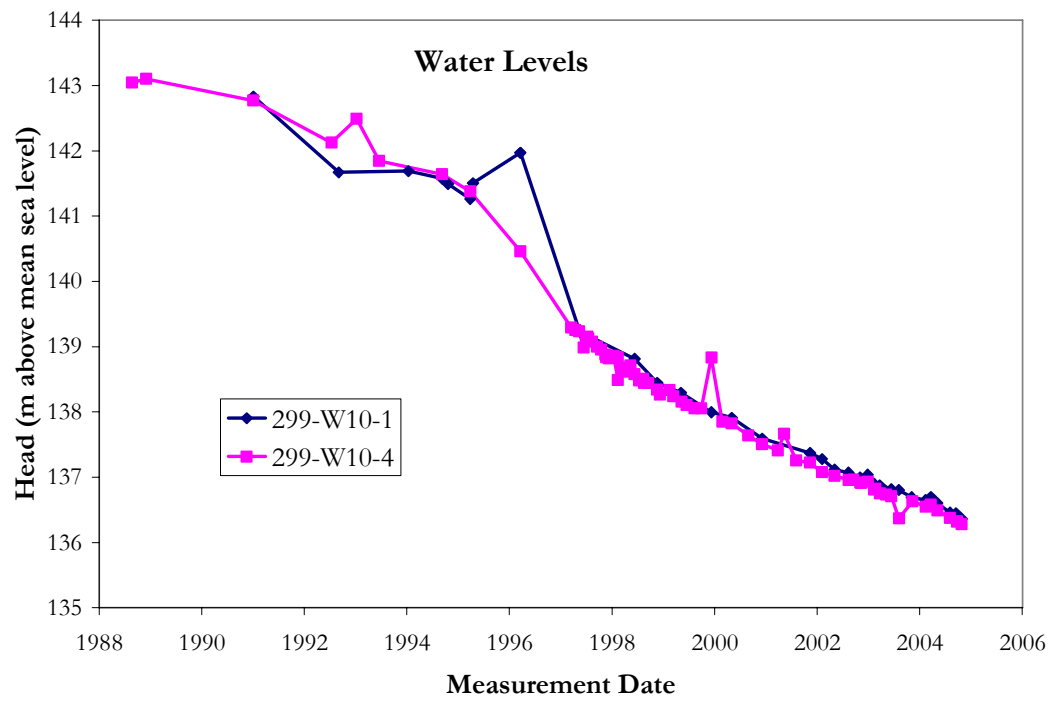

Figure 2.11. Hydrographs for Two Wells at Waste Management Area T

Table 2.8. Calculated Life Expectancy for Wells in the Waste Management Area T Monitoring Network

\begin{tabular}{|c|c|c|}
\hline Well Name & $\begin{array}{c}\text { Length of Saturated Screened } \\
\text { Interval }(\mathrm{m})^{(\mathrm{a})}\end{array}$ & Year Expected to Go Dry ${ }^{(b)}$ \\
\hline 299-W10-1 & $12.8^{(\mathrm{c})}$ & 2033 \\
\hline 299-W10-4 & $5.4^{(\mathrm{c})}$ & 2017 \\
\hline 299-W10-8 & 4.7 & 2015 \\
\hline 299-W10-22 & 2.6 & 2011 \\
\hline 299-W10-23 & 8.6 & 2024 \\
\hline 299-W10-24 & 8.5 & 2024 \\
\hline 299-W10-28 & 9.5 & 2026 \\
\hline 299-W11-7 & $7.2^{\text {(c) }}$ & 2021 \\
\hline 299-W11-12 & $4.3^{(\mathrm{c})}$ & 2015 \\
\hline 299-W11-39 & 9.6 & 2026 \\
\hline 299-W11-40 & 9.5 & 2026 \\
\hline 299-W11-41 & 9.1 & 2025 \\
\hline 299-W11-42 & 8.6 & 2024 \\
\hline \multicolumn{3}{|c|}{$\begin{array}{l}\text { (a) Based on second quarter FY } 2005 \text { water levels except 299-W10-22, 299-W10-28, and 299-W11-7 which is based } \\
\text { on first quarter FY } 2005 \text { data. } \\
\text { (b) Assuming an average of } 0.45 \mathrm{~m} / \mathrm{yr} \text { water-table decline. } \\
\text { (c) Perforated well. }\end{array}$} \\
\hline
\end{tabular}

\subsection{Contamination at Waste Management Area T}

This section summarizes the current and historical groundwater contamination at WMA T. Vadose zone contamination is also discussed because any residual vadose zone contamination is a potential source for future groundwater contamination.

As stated in Section 1.3, groundwater monitoring objectives of RCRA, CERCLA, and the AEA often differ slightly and the contaminants monitored are not always the same. For RCRA regulated units, monitoring focuses on non-radioactive dangerous waste constituents. Radionuclides (source, special 
nuclear and by-product materials) may be monitored in some RCRA unit wells to support objectives of monitoring under the AEA and/or CERCLA. Please note that pursuant to RCRA, the source, special nuclear and by-product material component of radioactive mixed waste are not regulated under RCRA and are regulated by DOE acting pursuant to its AEA authority. Therefore, while this report may be used to satisfy RCRA reporting requirements, the inclusion of information on radionuclides in such a context is for information only and may not be used to create conditions or other restrictions set forth in any RCRA permit.

\subsubsection{Groundwater Contamination}

Most of the information presented in this section is from Horton et al. (2002), Hartman et al. (2000, 2001, 2002, 2003, 2004, 2005), and Serne et al. (2004).

Chromium, carbon tetrachloride, and trichloroethene are the only dangerous waste constituents found in the groundwater beneath WMA T. Carbon tetrachloride and trichloroethene are monitored as part of the 200-ZP-1 Operable Unit. Nitrate and fluoride are also found in groundwater beneath the facility. In addition to the dangerous waste constituents, the non-RCRA-regulated constituents technetium-99 and tritium are found in groundwater at the WMA.

Groundwater chemistry in the vicinity of WMA T is dominated by high sodium, high nitrate groundwater containing varying concentrations of chromium, tritium, technetium-99, fluoride, carbon tetrachloride, and trichloroethene. These contaminants are a result of over 50 years of waste management activities in the 200 West Area.

Carbon tetrachloride is present in the unconfined aquifer beneath most of the 200 West Area (Figure 2.12). (Note that all plume maps in this document represent conditions in the upper approximately 9 to 10 meters of the unconfined aquifer.) The highest carbon tetrachloride concentration near WMA T in fiscal year 2004 was $1,800 \mu \mathrm{g} / \mathrm{L}$ in well 299-W10-4, south of the waste management area. High concentrations were also found north (299-W10-23) of the waste management area. The carbon tetrachloride is believed to be from pre-1973 waste from the Plutonium Finishing Plant and not from WMA T.

The major sources for trichloroethene are disposal sites associated with the Plutonium Finishing Plant. A second potential source is disposal near T Plant (Hartman et al. 2003). The maximum trichloroethene concentration found near WMA T in 2004 was about $10 \mu \mathrm{g} / \mathrm{L}$ in the north (well 299-W10-23) and south (well 299-W10-4) of the WMA (Figure 2.13). The waste management area is not considered a source for trichloroethene.

A tritium plume lies beneath WMA T and much of the north half of the 200 West Area (Figure 2.14). The plume geometry suggests that the major tritium source is to the south near WMA TX-TY, the 242-T evaporator, and nearby cribs (Hartman et al. 2004). Other contributing sources are likely present in the vicinity of the T Tank Farm and include associated cribs and trenches and, potentially, tank leaks. The highest tritium concentration near WMA T in 2004 was 51,000 pCi/L in well 299-W11-12, located at the southeast corner of the waste management area. Waste Management Area T is not thought to be a major contributor of tritium to the groundwater plume in the area. 


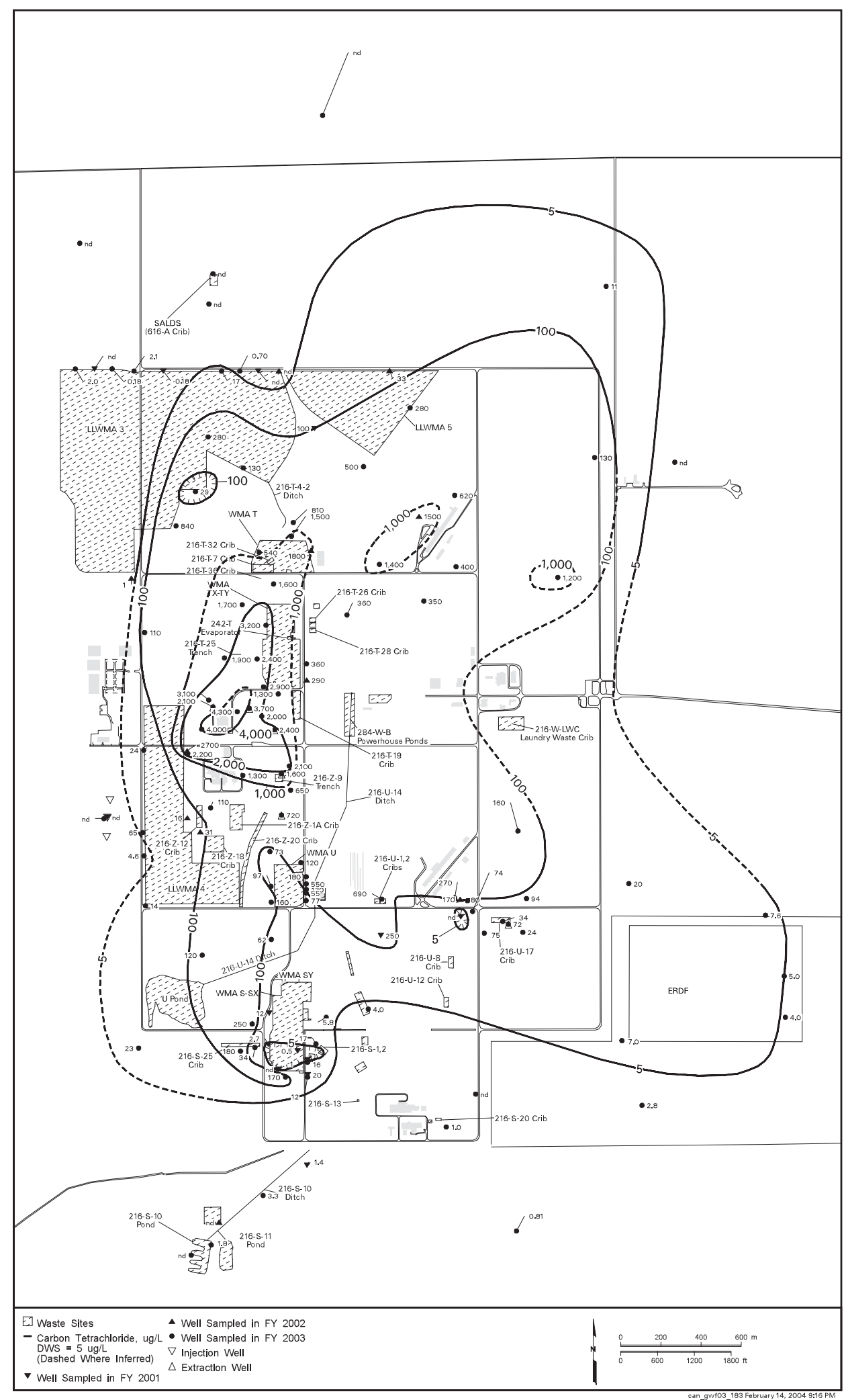

Figure 2.12. Average Concentration of Carbon Tetrachloride in the 200 West Area, Top of the Unconfined Aquifer (from Hartman et al. 2005) 


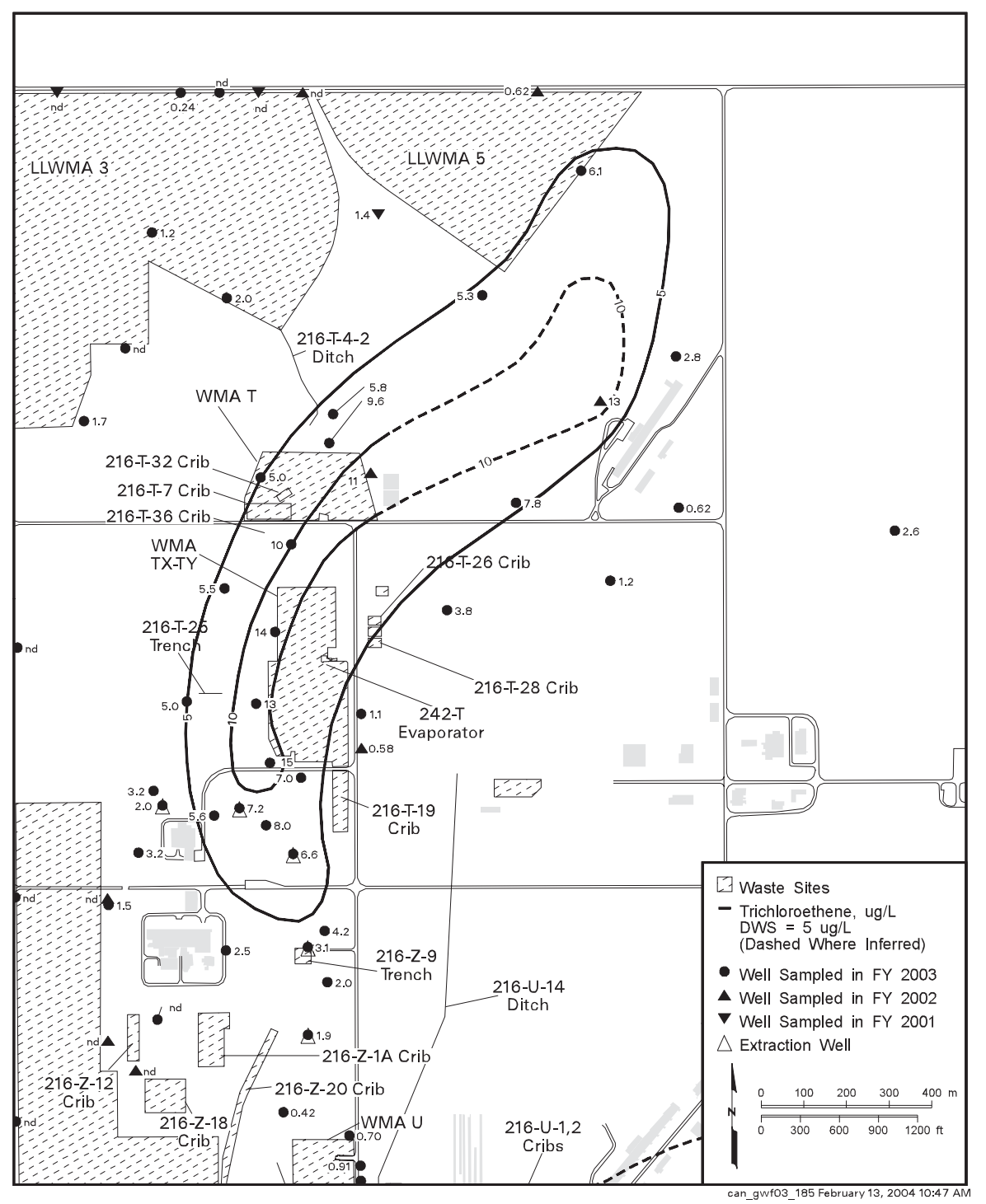

Figure 2.13. Average Concentrations of Trichloroethene in the North Part of the 200 West Area, Top of the Unconfined Aquifer (from Hartman et al. 2005)

A regional nitrate plume underlies WMA T and much of the north part of the 200 West Area (Figure 2.15). However, unlike, carbon tetrachloride, trichloroethene, and tritium, there also appears to be a source of nitrate local to, but upgradient of, WMA T. All monitoring wells in the WMA T monitoring network have nitrate concentrations in excess of the $45,000 \mu \mathrm{g} / \mathrm{L}$ maximum contaminant level in all monitoring wells.

The highest nitrate concentrations at the Hanford Site in fiscal year 2004 were from two upgradient wells at WMA T: 3,430,000 $\mu \mathrm{g} / \mathrm{L}$ in well $299-\mathrm{W} 10-4$ and 2,000,000 $\mu \mathrm{g} / \mathrm{L}$ in well $299-\mathrm{W} 10-28$. The nitrate concentration began to increase in well 299-W10-4 in about 1997 when the groundwater flow direction changed from northerly to easterly. Concentrations have continued to rise since that time. The nitrate concentration in well 299-W10-28 has always been greater than 1.12 million $\mu \mathrm{g} / \mathrm{L}$ since it was 
drilled in 2001. The most likely source for most the nitrate in this area is one or more of the past-practice liquid disposal facilities upgradient of the T Tank Farm.

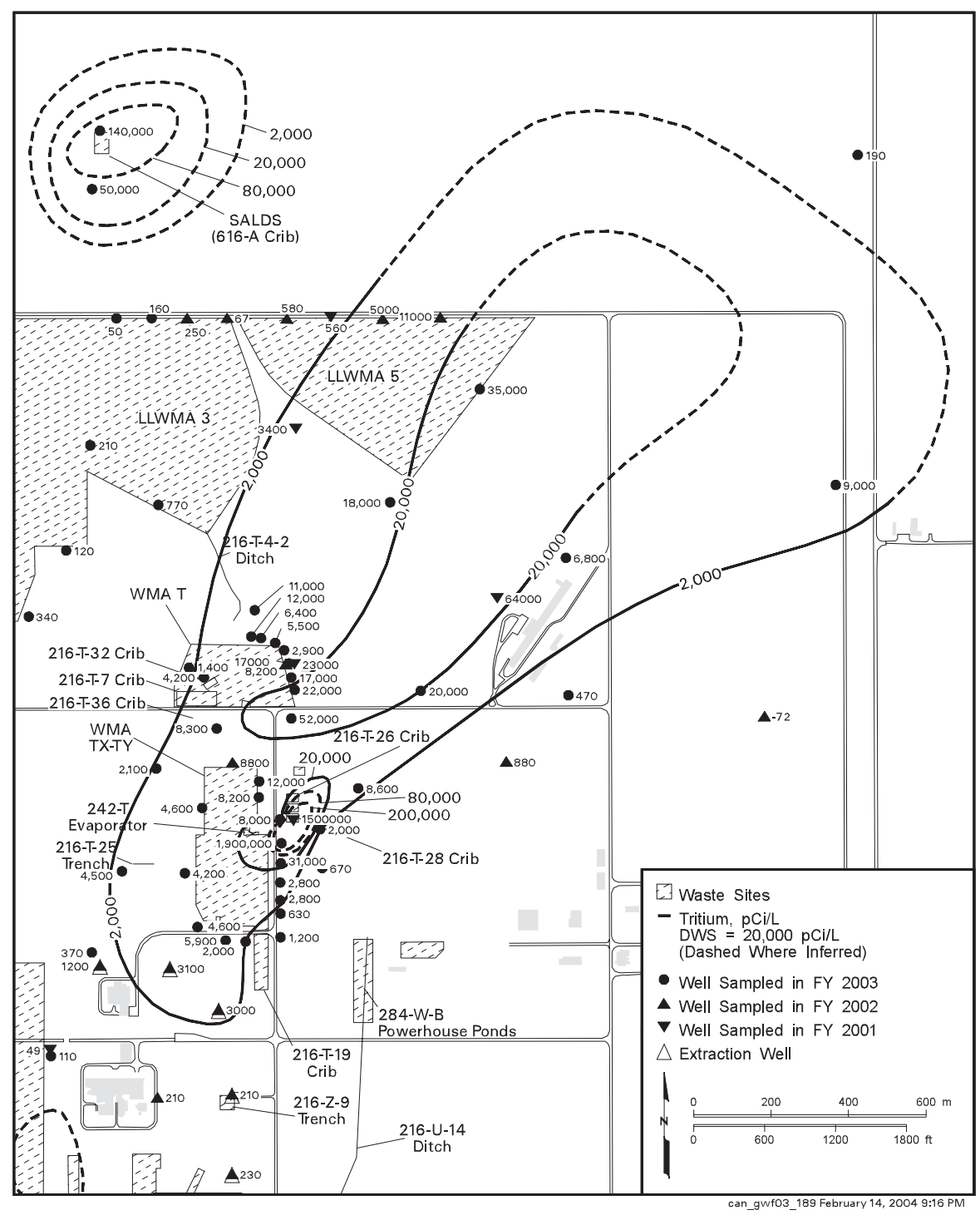

Figure 2.14. Average Concentrations of Tritium in the North Part of 200 West Area, Top of the Unconfined Aquifer (from Hartman et al. 2005)

Fluoride concentrations exceeded the drinking water standard of $4,000 \mu \mathrm{g} / \mathrm{L}$ in two wells at WMA T in 2004 and exceeded the secondary drinking water standard of $2,000 \mu \mathrm{g} / \mathrm{L}$ in five additional wells. Currently, the highest concentrations are in wells north of the WMA (Figure 2.16) but historically, the highest concentration was in well 299-W10-4 in late $1999(5,250 \mu \mathrm{g} / \mathrm{L})$. A fluoride plume appears to have passed well 299-W10-4 between mid-1997 and late 2000. 


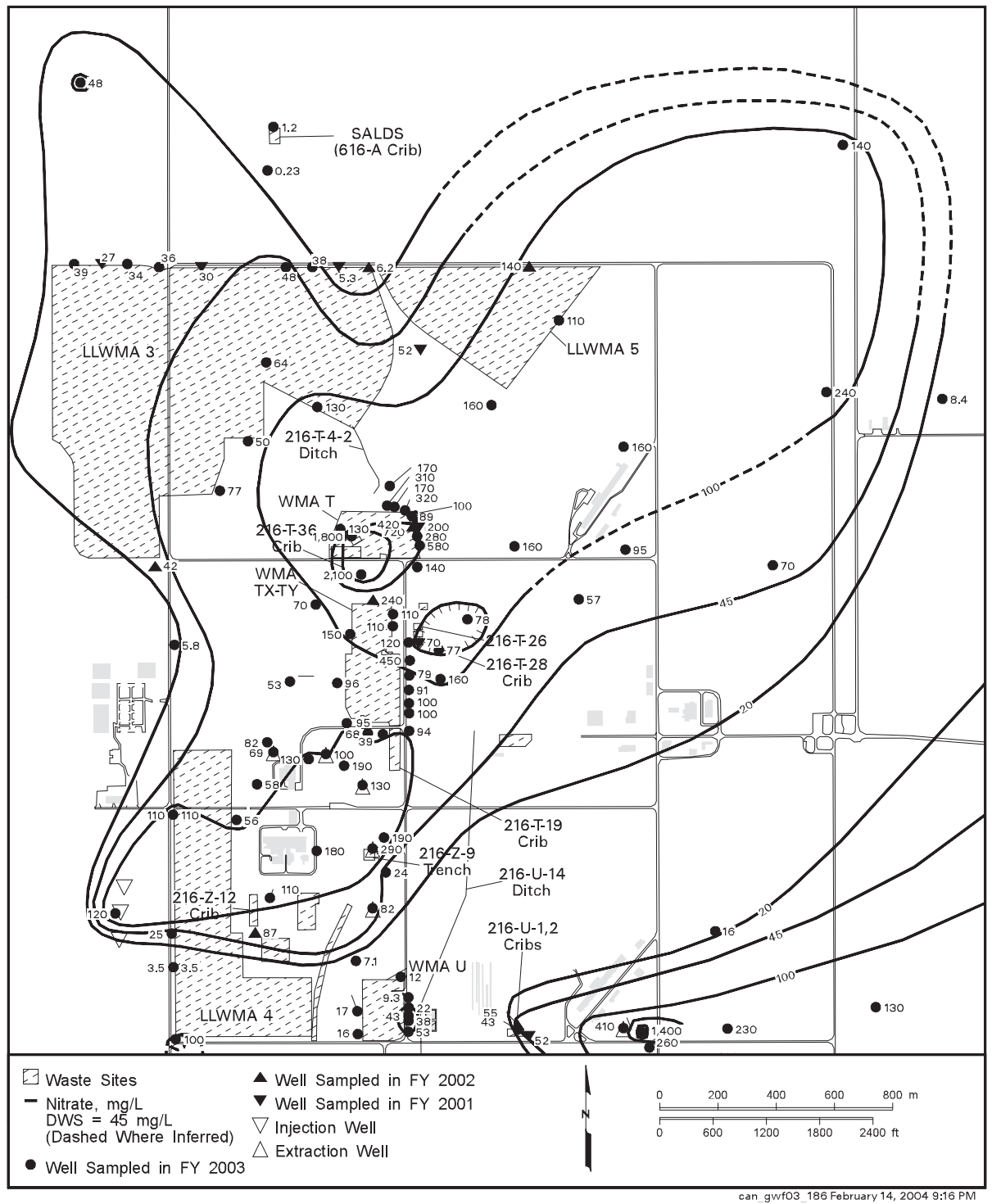

Figure 2.15. Average Concentrations of Nitrate in the North Part of 200 West Area, Top of the Unconfined Aquifer (from Hartman et al. 2005)

Although a tank farm source for the fluoride contamination has not been ruled out, one or more of the nearby cribs are believed to be a more likely source for much of the fluoride for two reasons. First, the highest concentrations of fluoride historically have been in upgradient wells located near potential fluoride sources (19,000 kilograms of fluoride disposed to the 216-T-7 crib and 16,000 kilograms of fluoride disposed to the 216-T-32 crib [Simpson et al. 2001]). Second, the fluoride/technetium-99 ratios vary from well to well at WMA T and with time in some individual wells (see Figure 2.17 for an example). If the technetium-99 has a source within the waste management area, as suggested below, the variation in the fluoride/technetium-99 ratios suggest a different source for most of the fluoride. However, some of the fluoride as well as some of the nitrate, chromium, and tritium in the groundwater is probably from tank waste in amounts proportional to their relative concentrations with respect to technetium-99. 


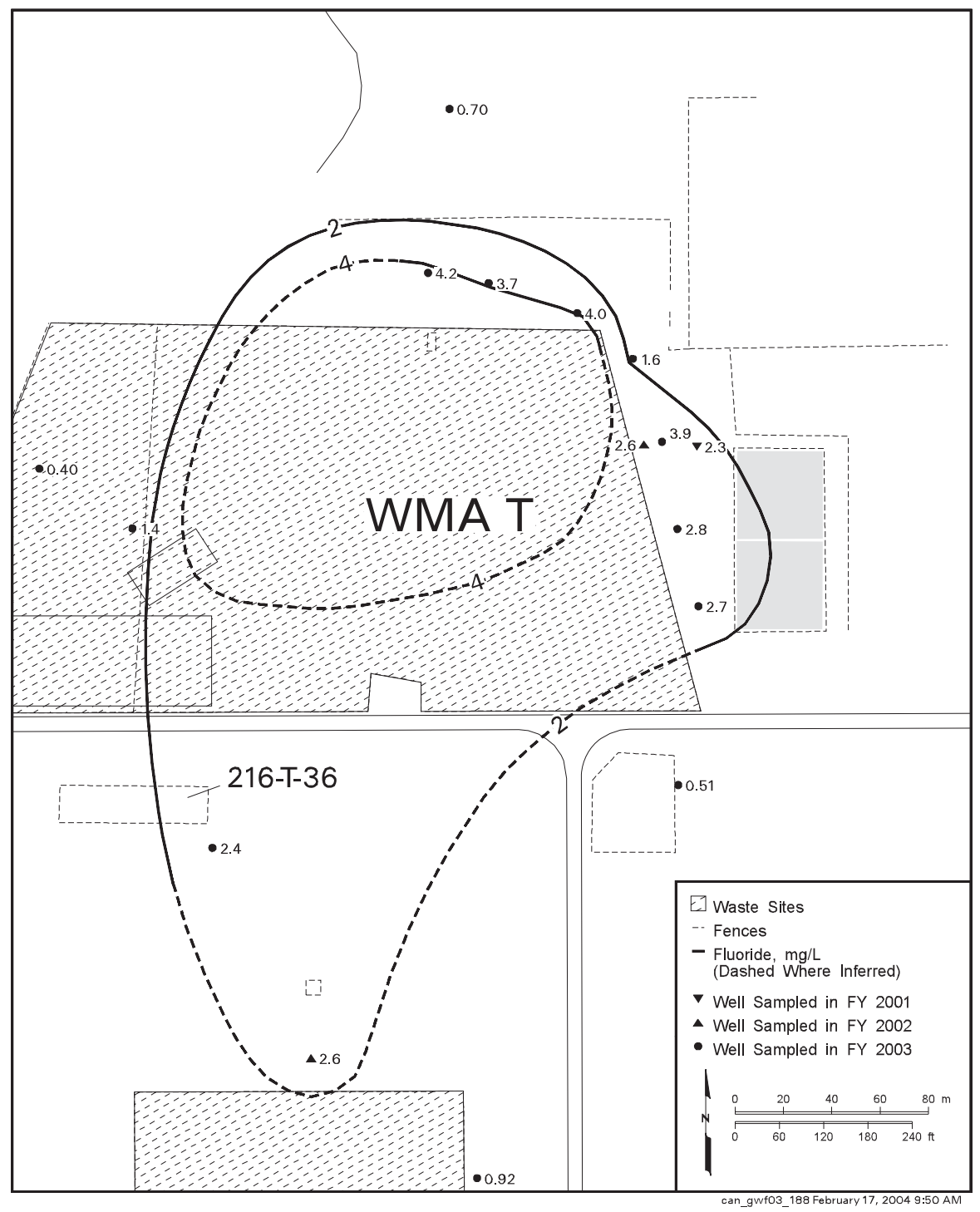

Figure 2.16. Average Concentrations of Fluoride in the Area of Waste Management Area T, Top of the Unconfined Aquifer (from Hartman et al. 2005)

A plume map for technetium-99 in the groundwater in the area of WMA T is shown in Figure 2.18. Technetium-99 began to increase in well 299-W11-27, located at the northeast corner of T Tank Farm, in late 1995, coincident with the cessation of surface water disposal in the 200 West Area. Concentrations reached a peak level of $21,700 \mathrm{pCi} / \mathrm{L}$ in February 1997 (Figure 2.18). Technetium-99 concentrations in well 299-W11-27 subsequently decreased to 6,000 pCi/L in March 1999 when the well went dry. Hodges (1998) suggested that technetium-99 had arrived at well 299-W11-27 by the early 1990s, but was diluted with water from a leaking water line located immediately adjacent to the well. The water line carried cooling and ventilation steam condensate, process cooling water, and evaporator condensate from the 207-T retention basin to the 216-T-4-2 ditch (DOE 1991) until 1995. Elimination of water discharge to the 216-T-4-2 ditch in June 1995 allowed contaminants to reach the well. The subsequent decrease in technetium-99 in well 299-W11-27 since 1997 may be a result of changing groundwater flow direction. 


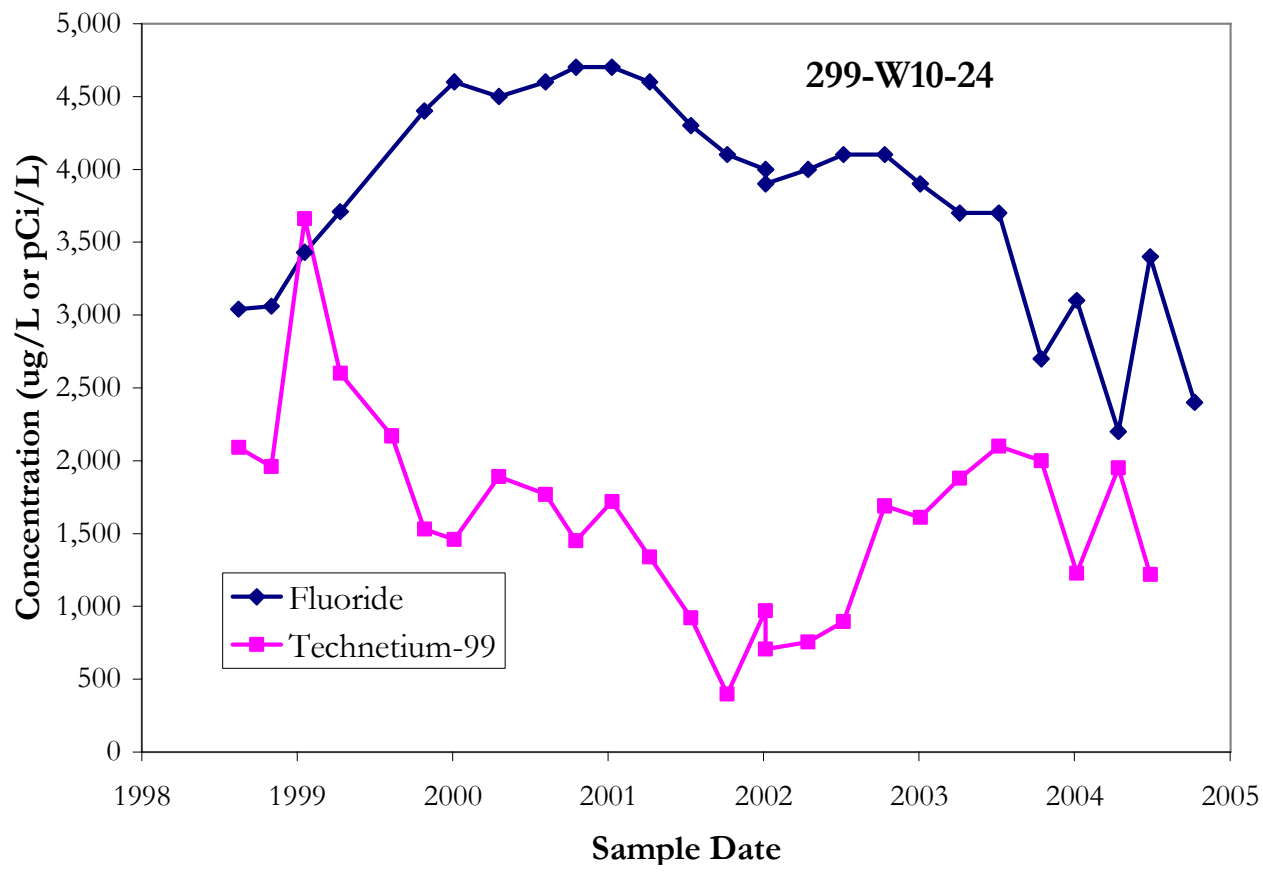

Figure 2.17. Technetium-99 and Fluoride Concentrations in Downgradient Well 299-W-10-24

Technetium-99 began to increase in well 299-W11-23, located east of well 299-W11-27, in November 1997 coincident with the change in groundwater flow to a more eastward direction. It increased to a high of 8,540 pCi/L in November 1998 (Figure 2.19). Subsequently, technetium-99 values fluctuated between 7,110 and $840 \mathrm{pCi} / \mathrm{L}$. The last sample from this well, taken in December 2000, indicated a technetium-99 concentration of 4,470 pCi/L. Sampling of replacement well 299-W11-39 in 2001 detected technetium- 99 concentrations between 4,160 and $5,010 \mathrm{pCi} / \mathrm{L}$, indicating contamination of the upper portion of the aquifer at this well. The technetium-99 concentration in this well rose to a high of $21,400 \mathrm{pCi} / \mathrm{L}$ in August 2004.

In early 2002, technetium-99 concentration began to increase in well 299-W11-42, south of well 299-W11-39 and, in early 2003, technetium-99 began to increase in well 299-11-41, south of 299-W11-42 (Figure 2.20). These increases suggest that a second technetium-99 plume or a portion of the technetium-99 plume first detected in the northeast corner of T Tank Farm is being detected along the entire east and downgradient side of the WMA.

Sampling during drilling of well 299-W10-24, in 1998, showed that the highest technetium-99 concentrations were at or very near the water table, at the northeast corner of the WMA, and concentrations decreased rapidly with increasing depth in the aquifer at the time the well was drilled. This suggested a nearby source for the technetium-99 because the contaminant had not traveled far enough to disperse vertically in the aquifer (Hodges 1998).

However, in February and March 2005, well 299-W11-25B was drilled to the Ringold Formation lower mud unit and encountered extremely high concentrations of technetium-99, nitrate, and chromium at 10.7 meters below the water table and deeper (Figure 2.21). (Well 299-W11-25B was damaged during construction and was replaced by well 299-W11-46.) Such high levels of contaminants at these depths 


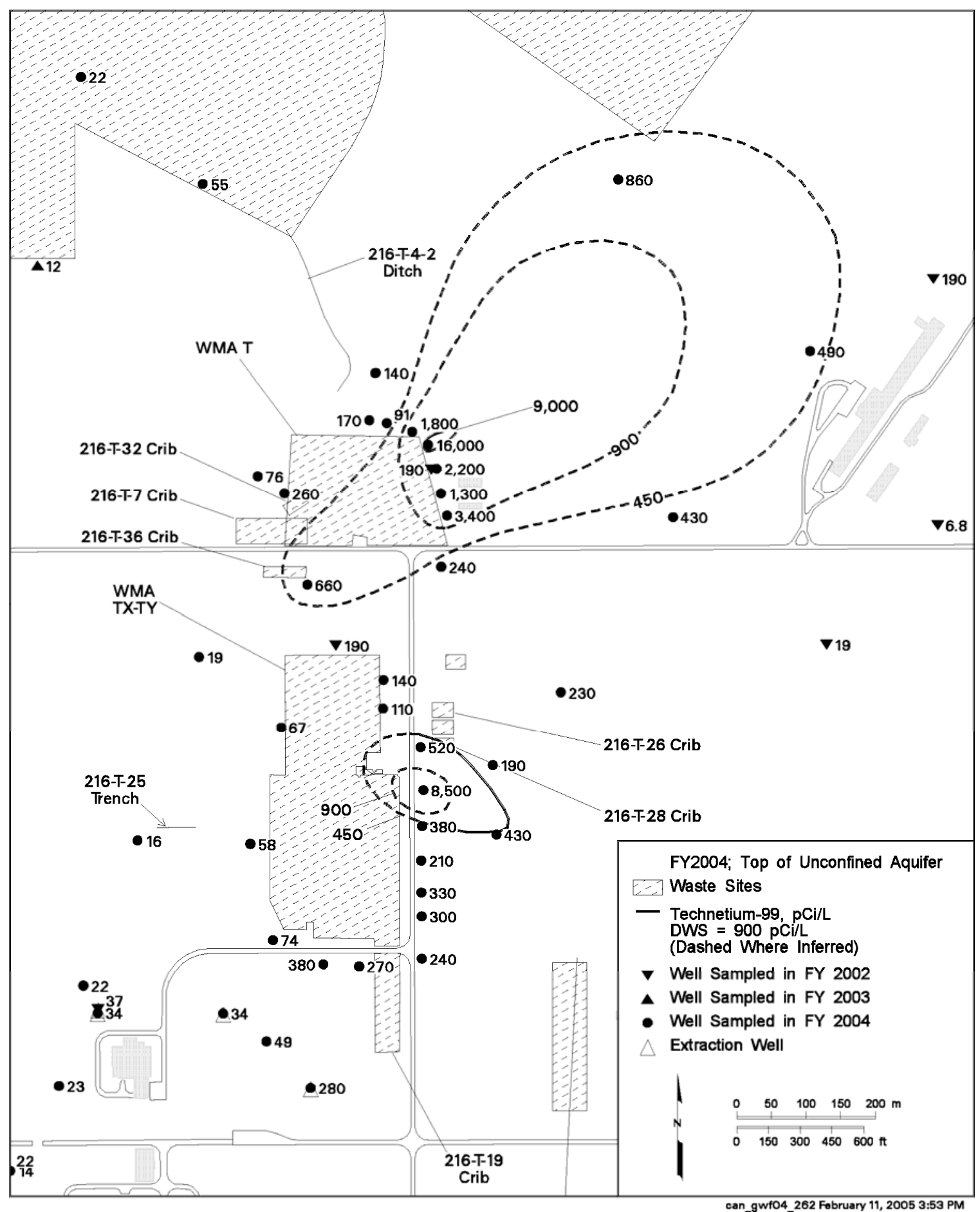

Figure 2.18. Average Concentrations of Technetium-99 in the Area of Waste Management Area T, Top of the Unconfined Aquifer (from Hartman et al. 2005) 


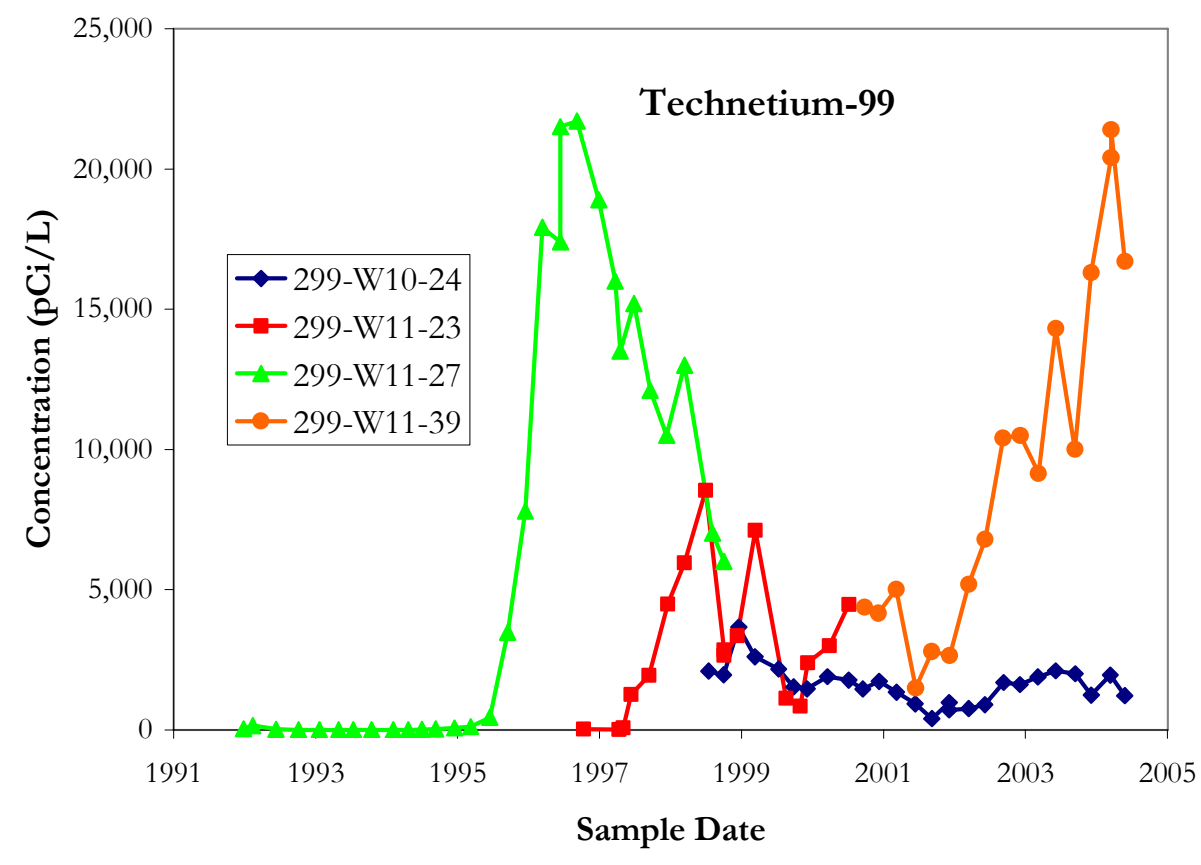

Figure 2.19. Technetium-99 Concentrations in Wells at the Northeast Corner of Waste Management Area T

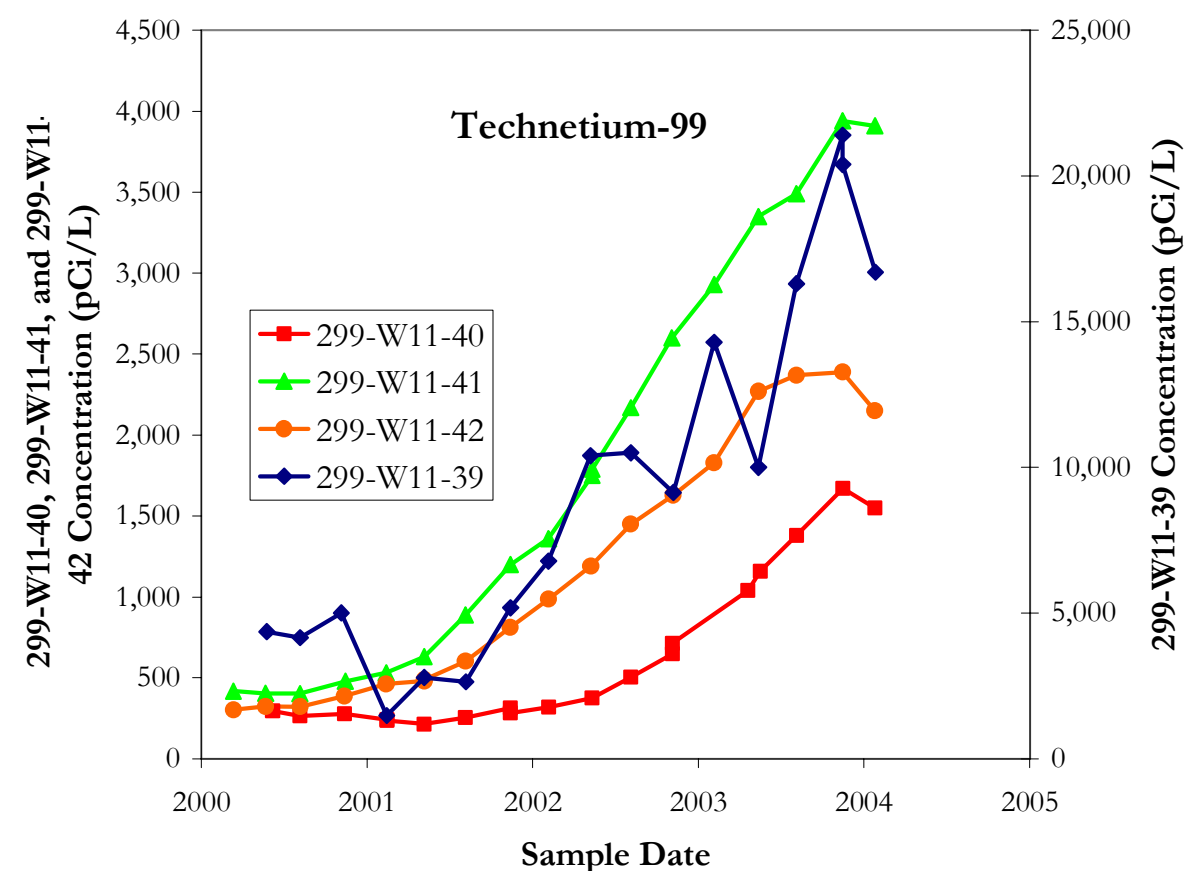

Figure 2.20. Technetium-99 Concentrations in Selected Downgradient Wells at Waste Management Area T 


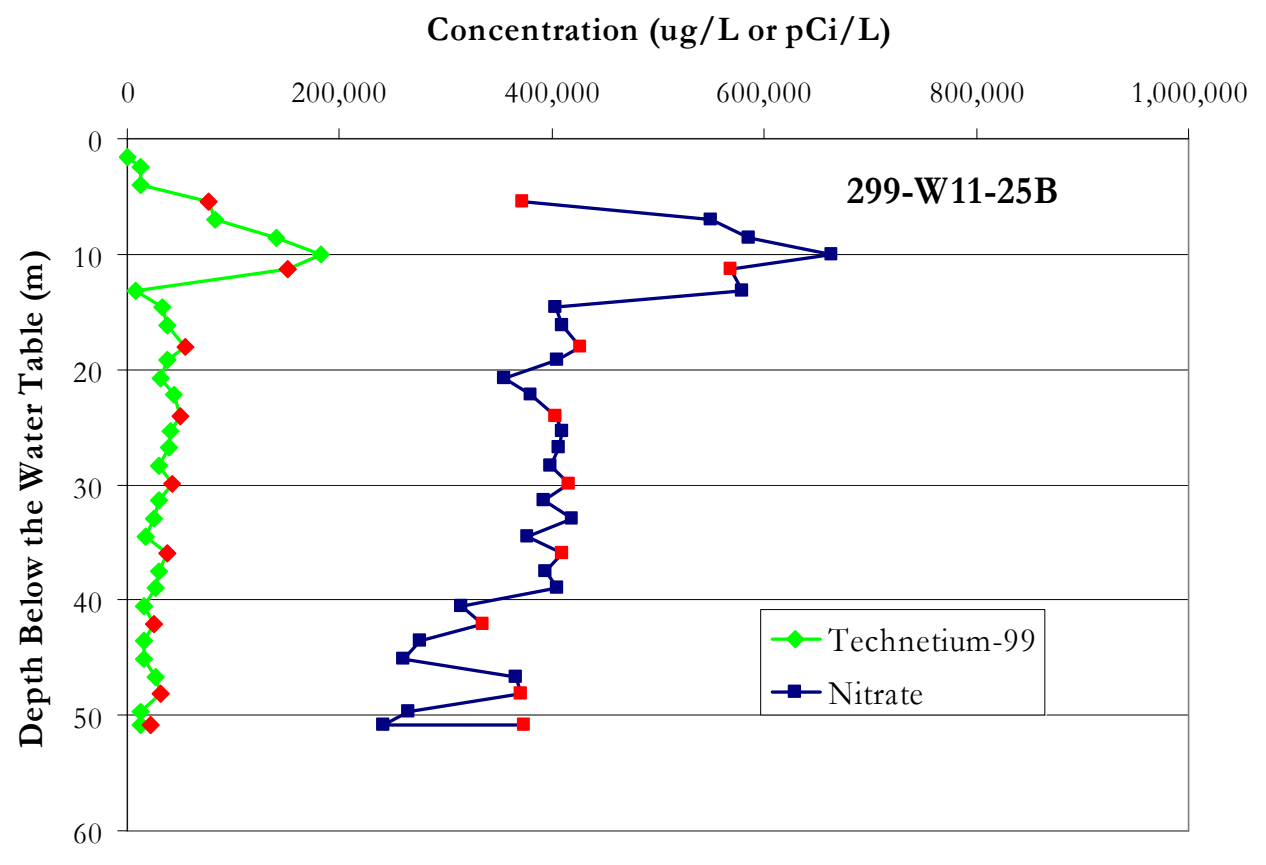

Figure 2.21. Concentrations of Technetium-99 and Nitrate Versus Depth Below the Water Table in Well 299-W11-25B. Red dots are pumped samples; all others are air lifted samples.

below the water table is contrary to what had been observed at well 299-W10-24 and at well 299-W14-13 at the WMA TX-TY (Hartman et al. 2004) where the highest concentrations of technetium-99 were at or near the water table. The reason for the high concentrations at depth in well 299-W11-25B is not fully understood. Part of the explanation may be the broken pipeline near well 299-W11-27. Data in Alexander et al. (1995) allow for an estimated maximum leakage of 1,800,764 liters of water between November 1992, when well 299-W11-27 was drilled, and June 1995 when discharge of all non-permitted effluent was stopped. This volume of water may have influenced the distribution of contamination in the aquifer. Further characterization is needed to fully understand the vertical distribution of contaminants in the area.

Also unknown is the lateral extent of the contamination at depth within the aquifer. Characterization to delineate the lateral extent is addressed in the DQOs in Chapter 3.0 of this plan. ${ }^{1}$

Figures 2.21 and 2.22 show the concentrations of selected constituents with depth in the aquifer in well 299-W11-25B. Figure 2.21 shows that the technetium-99 concentration near the water table is relatively low $(238 \mathrm{pCi} / \mathrm{L})$ but rapidly increases to a maximum of $181,600 \mathrm{pCi} / \mathrm{L}$ at 10 meters below the water table. The technetium-99 concentration decreases below the 10-meter depth but remains elevated at between 20,000 and $50,000 \mathrm{pCi} / \mathrm{L}$ to total depth of the well. The maximum nitrate concentrations also are at the 10-meter depth below the water table. The concentrations of nitrate and technetium-99 appear to track each other with depth in the aquifer.

\footnotetext{
${ }^{1}$ At the time this document was prepared, two new wells were under construction to help delineate the vertical and horizontal extent of contamination at WMA T (see Section 3.4.3).
} 
The chromium and manganese concentrations in well 299-W11-25B are shown in Figure 2.22. Two types of samples were collected during drilling of the well. The blue points on the figure represent air lifted samples of drill cutting and groundwater. The red points represent samples collected by pumping after extensive purging of the well. There is a substantial difference between the air lifted and pumped results. The groundwater associated with the air lifted samples was in contact with the drill cuttings for at least 24 hours before analysis. It is probable that the soluble $\mathrm{Cr}^{6+}$ was reduced to insoluble $\mathrm{Cr}^{3+}$ by being in contact with pulverized rock in the drill cuttings. Extensive purging of the well before collection of the pumped samples removed most or all of the groundwater affected by drilling so that the resulting chromium concentrations were unaffected by reducing conditions created during drilling. The highest chromium concentration in the pumped samples was $1,033 \mu \mathrm{g} / \mathrm{L}$ at 5.5 meters below the water table.

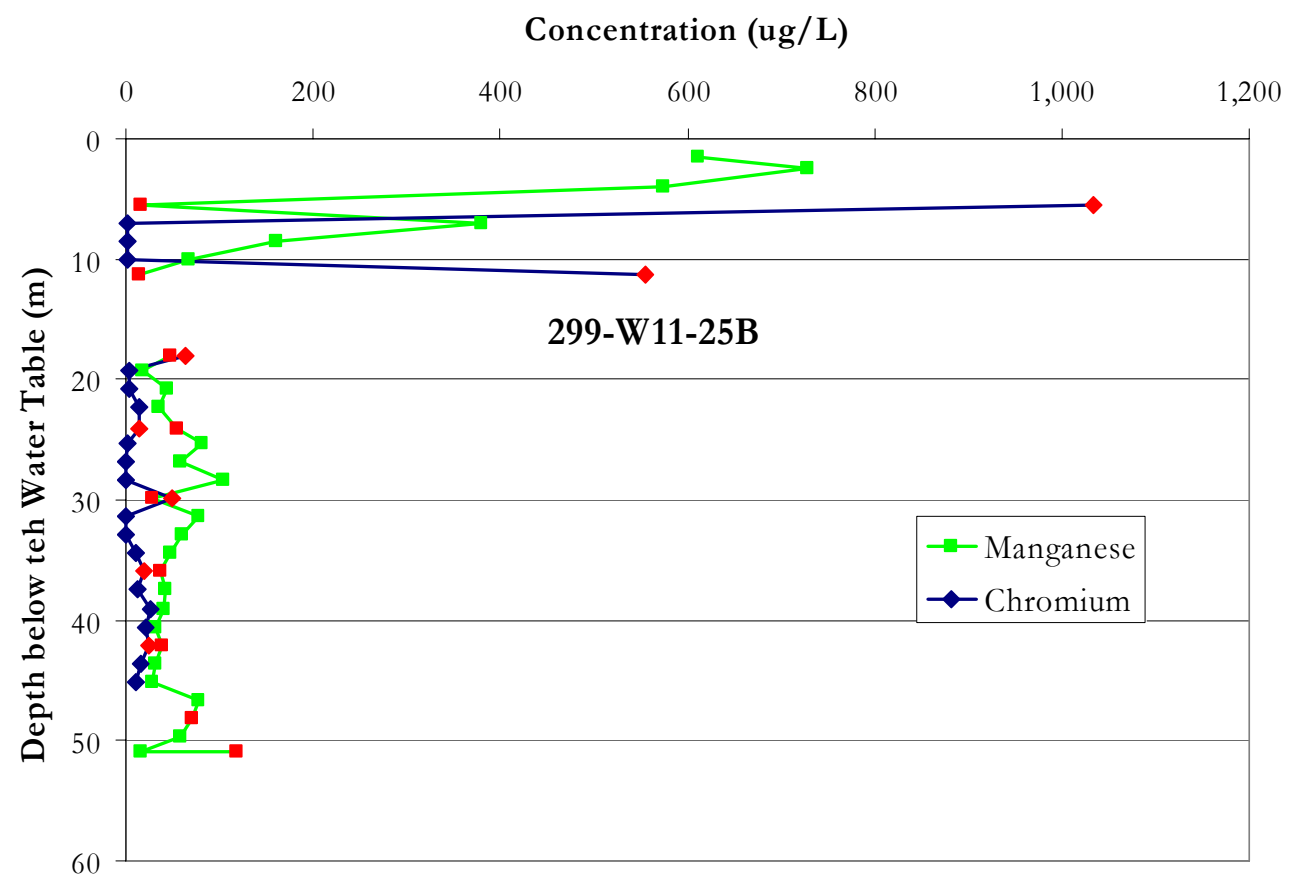

Figure 2.22. Concentrations of Chromium and Manganese Versus Depth Below the Water Table in Well 299-W11-25B. Red dots are pumped samples; all others are air lifted samples.

The distribution of manganese (Figure 2.22) supports the reduction of chromium in the air lifted samples. Soluble $\mathrm{Mn}^{2+}$ is expected to be released from the basaltic sediments during drilling and it is this manganese that is measured during analysis of the air lifted samples. Purging the well before collecting the pumped samples removes the artificially introduced manganese and more natural, background manganese concentrations result.

Because of the high technetium-99 concentrations found in well 299-W11-25B, two new wells were proposed to help delineate the vertical and horizontal extent of the contamination (see Section 3.4.3 and Appendix A). Both wells were under construction at the time this plan was being written and groundwater samples collected during drilling of one of them, well T-2 (299-W11-45), had been analyzed. A brief discussion of the preliminary results is give here. The location of the well is shown on Figure 2.23. 


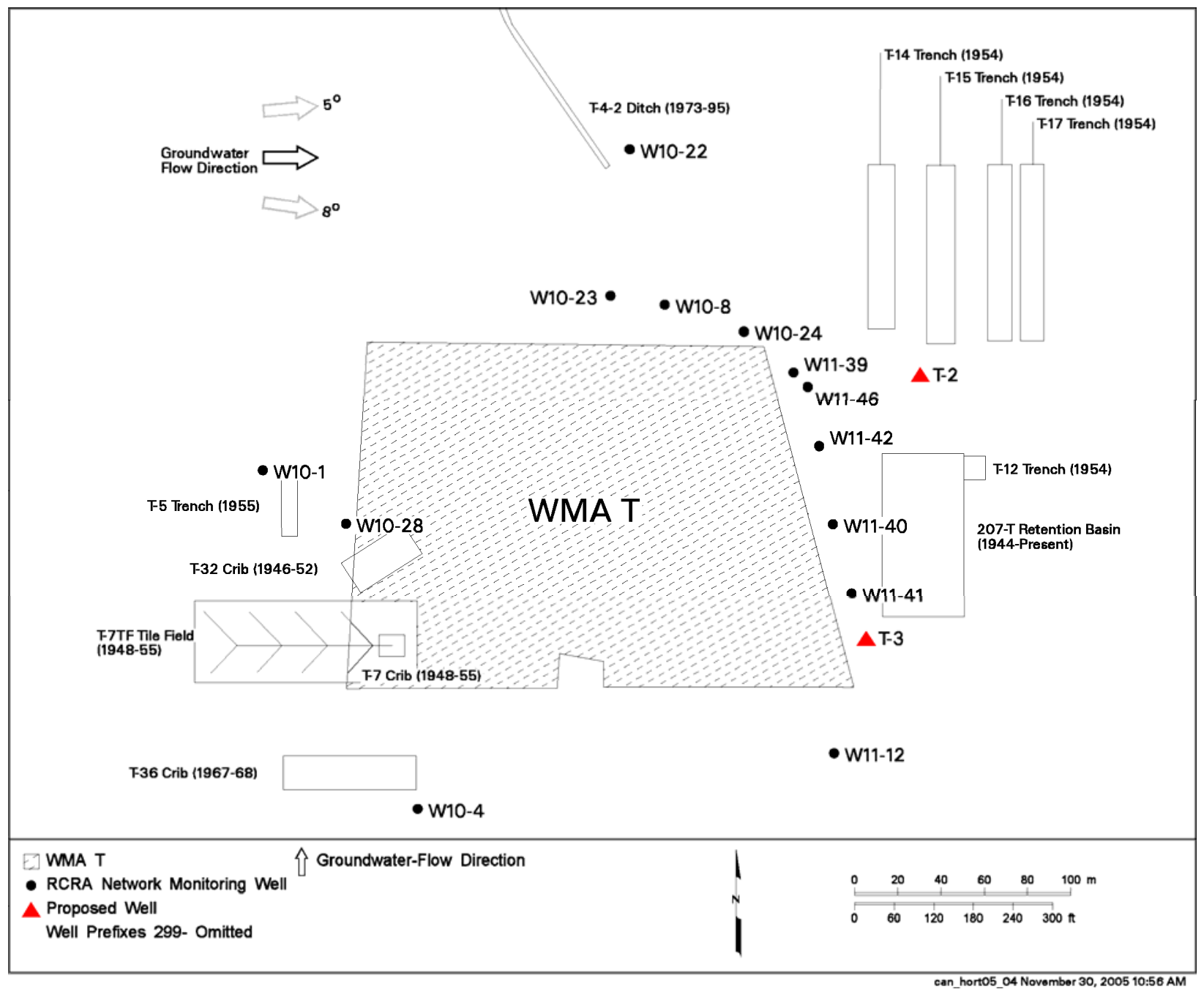

Figure 2.23. Current Groundwater Monitoring Network for Waste Management Area T. Proposed wells are indicated by red triangles.

Drilling began on well 299-W11-45, located $\sim 80$ meters downgradient of well 299-W11-25B, in September 2005. Groundwater from the well was sampled every 1.5 meters throughout the upper 56 meters of the aquifer. The technetium-99 and nitrate concentrations found during drilling are shown on Figure 2.24.

The maximum technetium-99 concentration found during drilling of well 299-W11-45 was $15,646 \mathrm{pCi} / \mathrm{L}$ at 9.1 meters below the water table. The depths of the maximum concentrations are similar in wells 299-W11-25B and 299-W11-45. Although the technetium-99 concentration is very high in well $299-W 11-45$, it is much less than the $181,000 \mathrm{pCi} / \mathrm{L}$ maximum found in well $299-\mathrm{W} 11-25 \mathrm{~B}$. This suggests that, if the technetium-99 found in the two wells is from the same plume, the front edge of the plume is probably a short distance east of well 299-W11-45.

The nitrate and technetium-99 concentrations tracked each other in well 299-W11-25B. This does not seem to be the case in well 299-W11-45 (Figure 2.24). The maximum nitrate concentration $(590,000 \mu \mathrm{g} / \mathrm{L})$ roughly coincides with the maximum technetium-99 concentration, but the nitrate has a 
much broader high concentration interval before gradually decreasing. Both wells are located in the regional nitrate plume and, perhaps, the regional nitrate masks the nitrate associated with the technetium-99 at lower technetium-99 concentrations (and presumably lower associated nitrate concentrations).

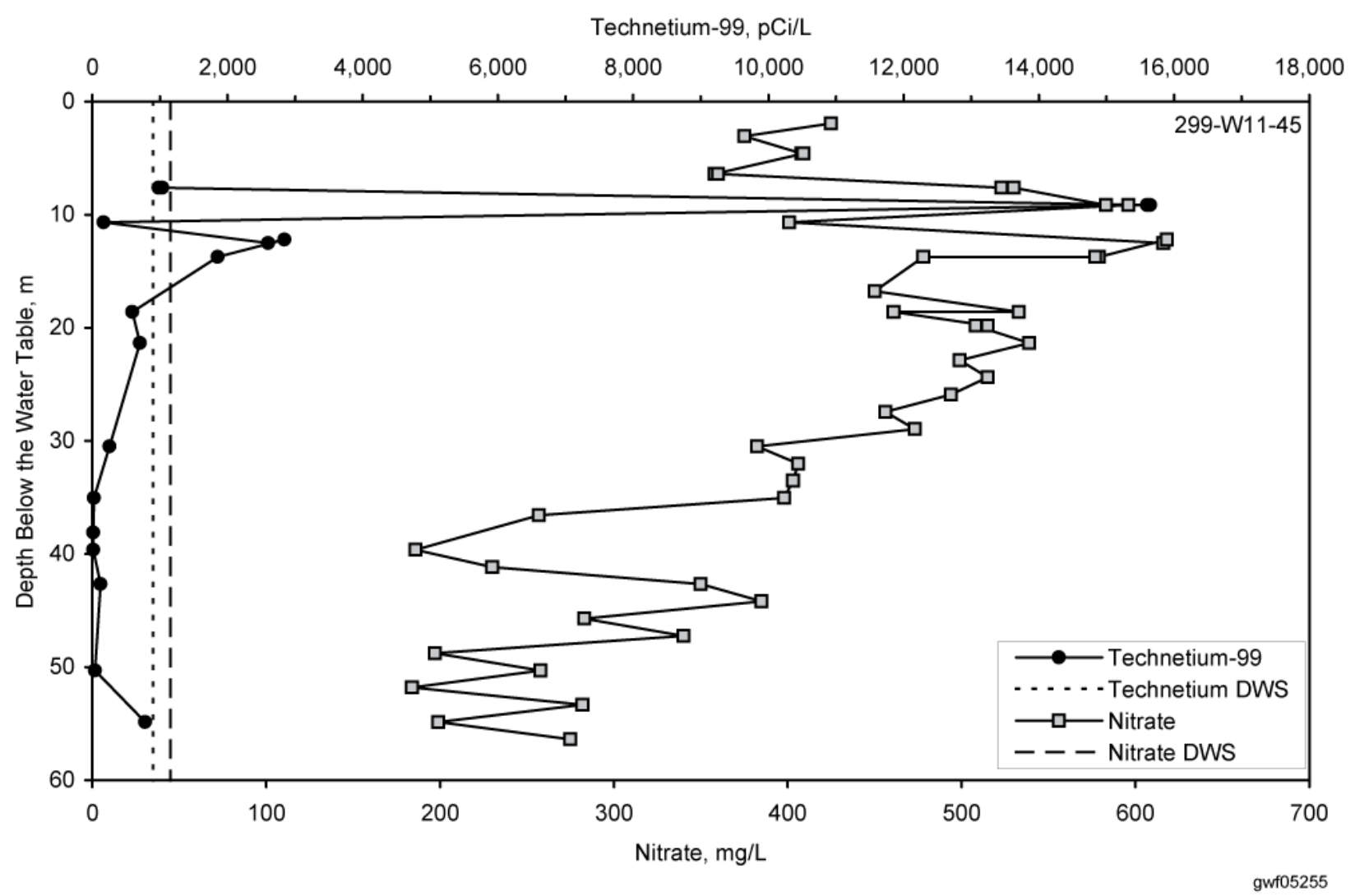

Figure 2.24. Technetium-99 and Nitrate Concentrations Encountered During Drilling of Well 299-W11-45

A plume map depicting the fiscal year 2004 average chromium concentration in wells near WMA T is shown in Figure 2.25. The highest chromium concentrations are in wells 299-W10-28 and 299-W10-4 where chromium reached 316 and $772 \mu \mathrm{g} / \mathrm{L}$, respectively, in 2004. Prior to about 1997 when groundwater flow direction was toward the north, several wells on the north (then downgradient) side of the waste management area had relatively high chromium concentrations. Also, prior to 1997, well 299-W10-1, which was lateral to the tank farm with respect to groundwater flow direction but downgradient of the 216-T-5 trench, the 216-T-7 crib and tile field, and the 216-T-32 crib, had chromium concentrations exceeding $200 \mu \mathrm{g} / \mathrm{L}$. After flow direction changed toward the east in about 1997, chromium concentrations dropped to $<40 \mu \mathrm{g} / \mathrm{L}$ in well $299-\mathrm{W} 10-1$, decreased in all of the northern wells, and began increasing in well 299-W10-4 (see the chromium trend plots in Figure 2.26). The most likely source for the chromium west and north of WMA T is one or more of the disposal facilities upgradient of the WMA. (The 216-T-5 crib received 3,920 kilograms of chromium and the 216-T-32 crib received 2,490 kilograms of chromium [Simpson et al. 2001].) Chromium from these facilities would have been moving north across well 299-W10-1 prior to 1997 and then east across the northern wells and the rest of the waste management area after 1997. 


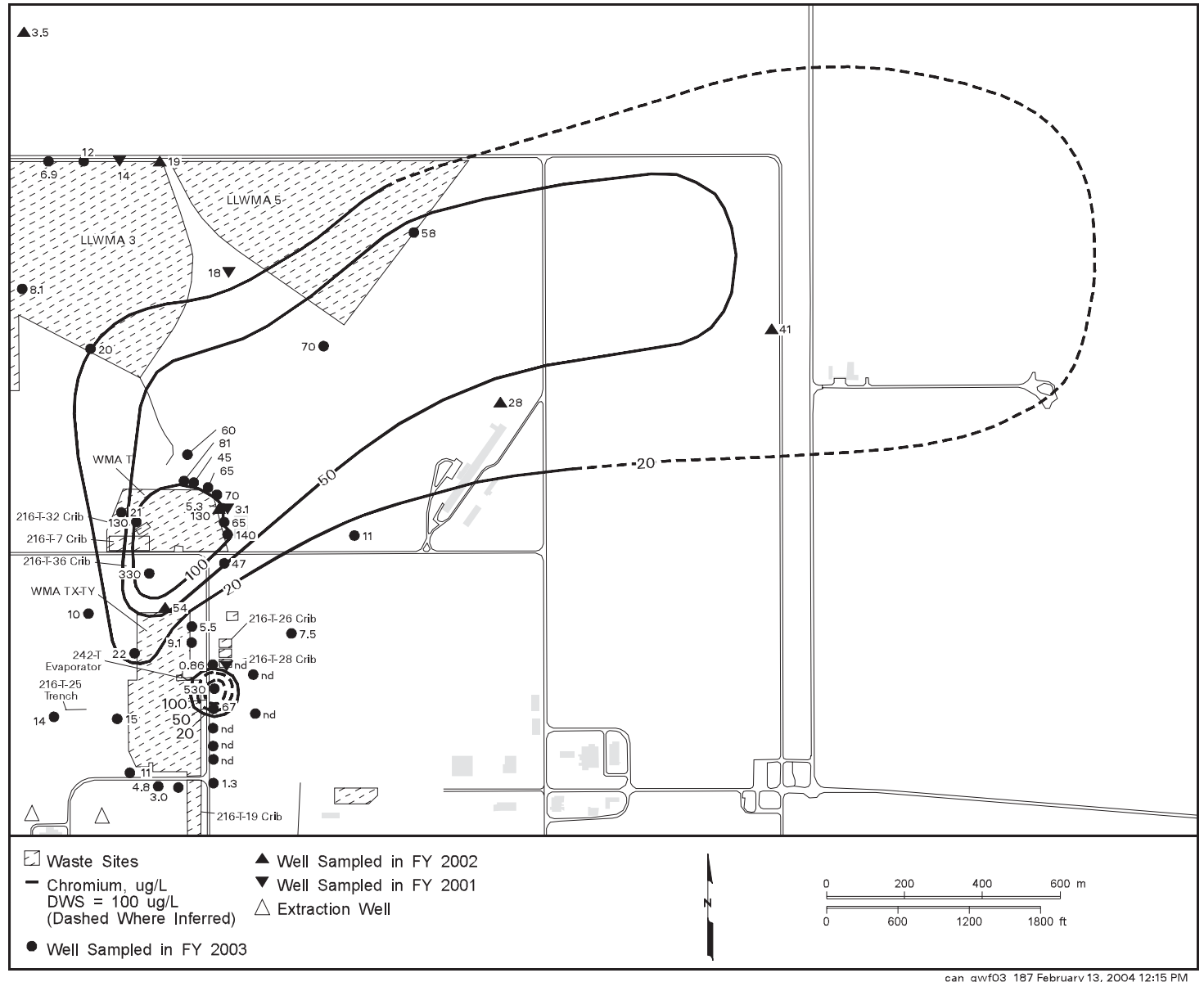

Figure 2.25. Average Concentrations of Chromium in the Area of Waste Management Area T, Top of the Unconfined Aquifer (from Hartman et al. 2005)

Figure 2.26 shows the concentrations of chromium and technetium-99 in selected wells at WMA T. The relative concentrations of technetium-99 and chromium track each other through time in upgradient wells at the WMA (Figure 2.26A) and the same relationship holds for wells north of the WMA (Figure 2.26B) where groundwater contamination is most likely from the disposal facilities west of the T Tank Farm.

The technetium-99 - chromium concentration relationship is different in wells located at the northeast corner (Figure 2.26C) and east of the WMA (Figure 2.26D) than it is to the west and north. On the east and northeast sides, the concentrations of the two constituents do not appear to track each other. This is especially evident in wells to the east. The trends in Figures 2.26C and 2.26D suggest that there are two different sources for either the technetium-99 or the chromium or both.

In 2004, the technetium-99/chromium concentration ratios in groundwater was compared to the estimated concentration ratios of single-shell tank leaks from tanks T-101 and T-106 and to the concentration ratios of some cribs and trenches in the area of WMA T (Hartman et al. 2005; Serne et al 2004). The conclusion was made that crib waste had impacted the groundwater in the southwest, north, and east of 

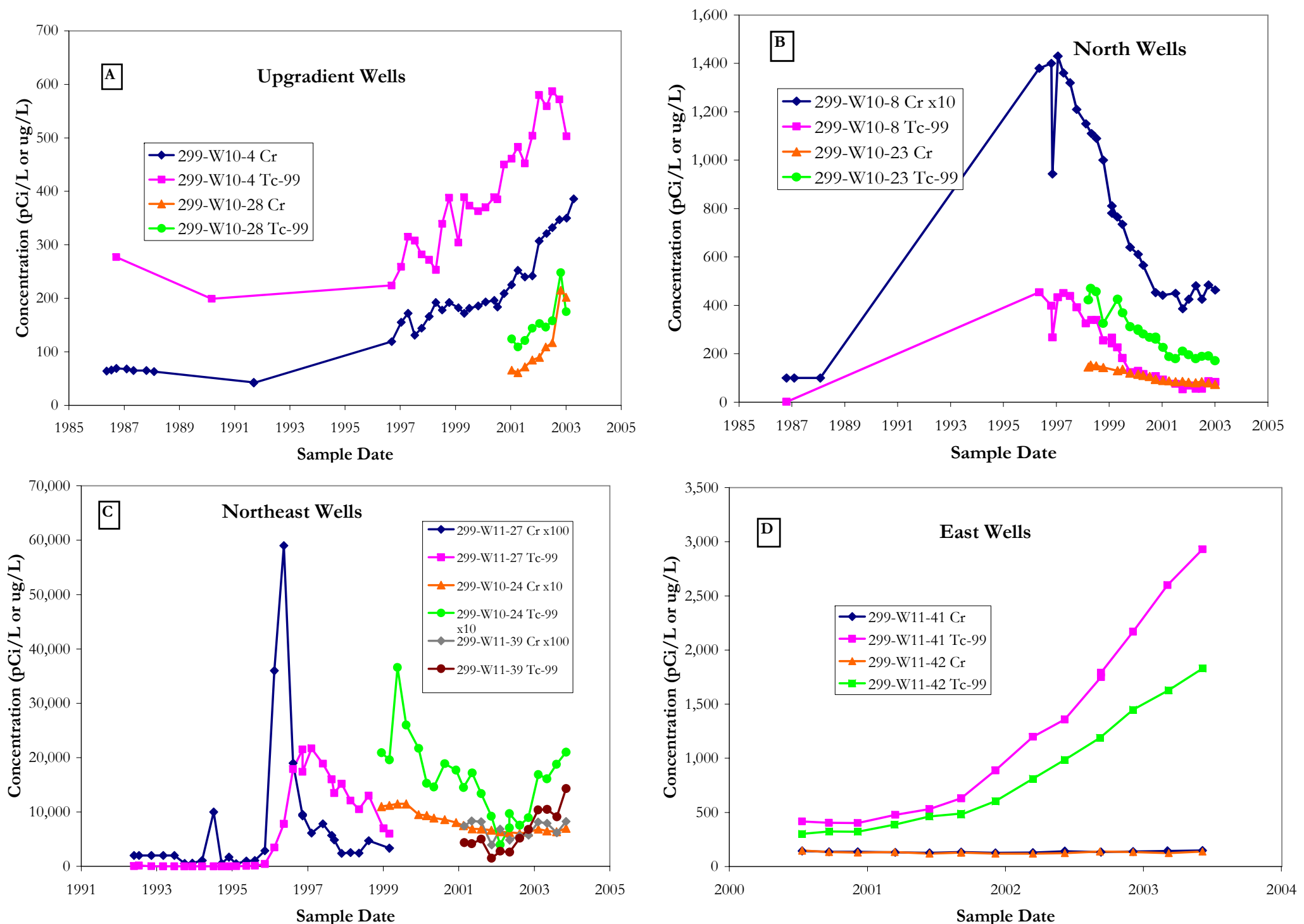

Figure 2.26. Technetium-99 and Chromium Concentrations in Selected Wells at Waste Management Area T 
the WMA and tank waste has impacted the recent groundwater in the east and northeast of the WMA. Those conclusions were based on 2001 estimates for the tank leaks and discharges to past-practice disposal facilities (Jones et al. 2000; Simpson et al. 2001). Leak and discharge inventory estimates were updated in fiscal year 2005 (Corbin et al. 2005), and the new data necessitate a reinterpretation of the groundwater data.

Figure 2.27 shows the technetium-99/chromium composition ratios in samples of groundwater from selected wells at WMA T compared to the estimated compositions for two tank leaks and several pastpractice disposal facilities in the area. As was previously concluded (Hartman et al. 2005, Serne et al. 2004), the figure shows that, after about 1995, groundwater in the northeast part of the WMA (Figure 2.27C), and probably the more recent samples from wells east of the WMA (Figure 2.27D) was impacted by tank waste. However, groundwater in the southwest, west, and north parts of the WMA do not appear to have been influenced to any great extent by waste disposed to the nearby cribs and trenches, east of the WMA, as was previously concluded (Figure 2.27A and B).

Figure 2.28A shows the technetium-99/chromium composition ratios estimated for two tank leaks and several past-practice facilities ${ }^{2}$ with ratios from 1:1 water:sediment extracts (vadose zone pore water) collected from two boreholes drilled through the tank T-106 leak (Serne et al. 2004b). Supposedly, the pore water collected from the two T-106 characterization boreholes represents the fluid leaked from the tank. The vadose zone data show several orders of magnitude variation but are more similar to the estimated tank leaks than to the estimated composition of the past-practice waste.

The technetium-99/chromium composition ratios for borehole $\mathrm{C} 4105$ are generally larger than those from borehole $\mathrm{C} 4104$. The differences may be because borehole $\mathrm{C} 4104$ is located closer to the actual leak and any retardation of chromium relative to technetium- 99 will increase the ratio in the more distant borehole $\mathrm{C} 4105$.

Figure 2.28B compares estimated technetium-99/chromium ratios with ratios in groundwater collected during drilling of boreholes 299-W11-25B and 299-W11-45. The technetium-99/chromium composition ratios from the groundwater samples are closer to the estimated composition of the tank fluids in the pore water collected from the characterization boreholes than they are to the estimated composition of the past practice facilities. However, the groundwater ratios vary by up to about three orders of magnitude within the same well (299-W11-25B).

Figure 2.29 compares the technetium-99/nitrate ratios in samples of groundwater from selected wells at WMA T with estimated compositions for two tank leaks and several past-practice disposal facilities in the area. The technetium-99/nitrate concentration ratios suggest the same conclusions reached with the technetium-99/chromium ratios. That is, groundwater from wells at the northeast corner of WMA T has a technetium/nitrate composition similar to estimated tank leak fluids.

\footnotetext{
${ }^{2}$ Estimated tank leaks and past-practice facility waste compositions are from the Hanford Soil Inventory Model, Rev. 1 (Corbin et al. 2005) as presented by C Kincaid in a November 16, 2005, T-Area Technetium-99 Data Quality Objectives workshop.
} 

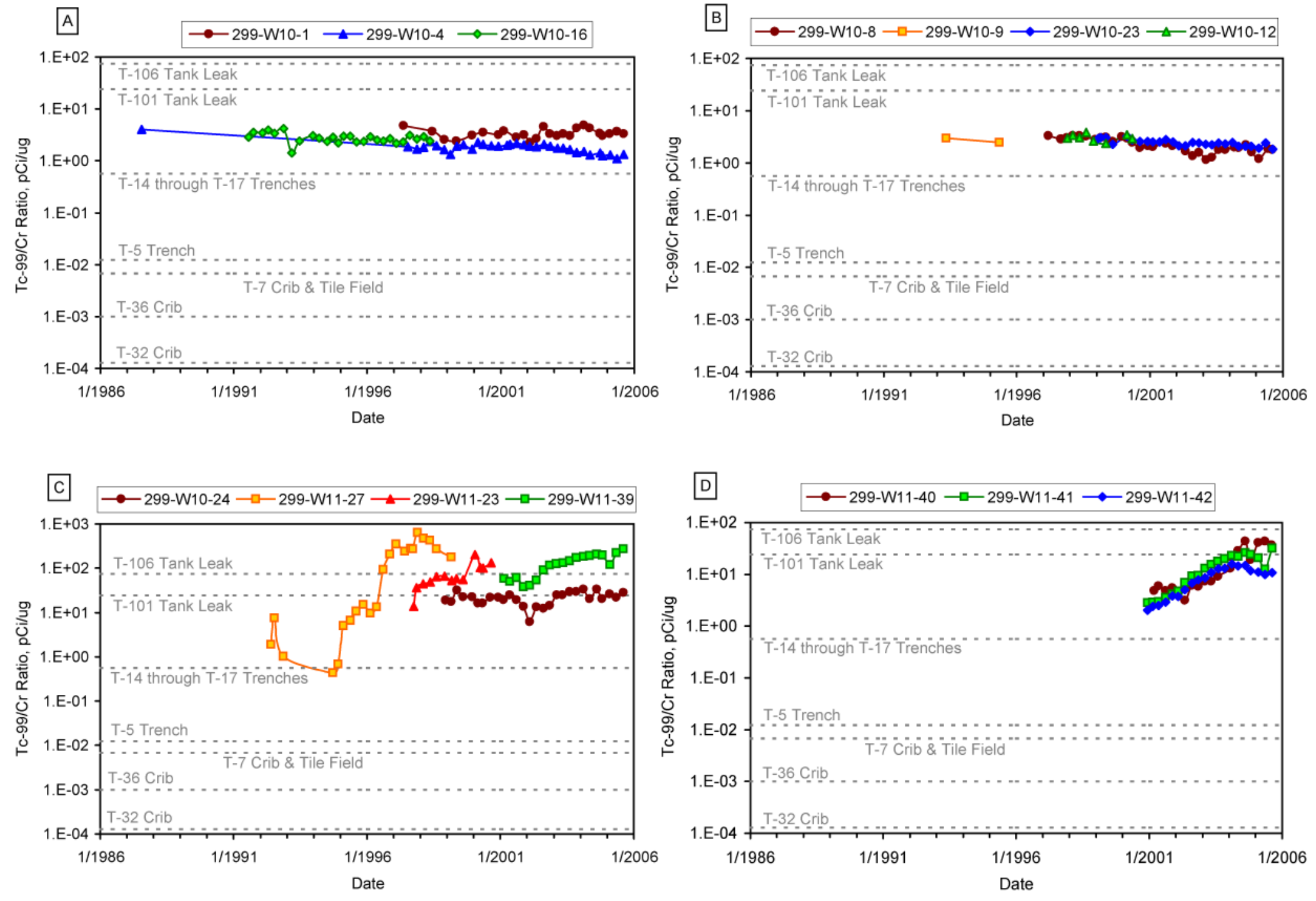

Figure 2.27. Technetium-99/Chromium Concentration Ratios in Samples from Selected Wells at Waste Management Area T. $($ A $)=$ upgradient (West) wells; (B) = northern wells; (C) = northeastern wells; (D) = eastern (downgradient wells). 


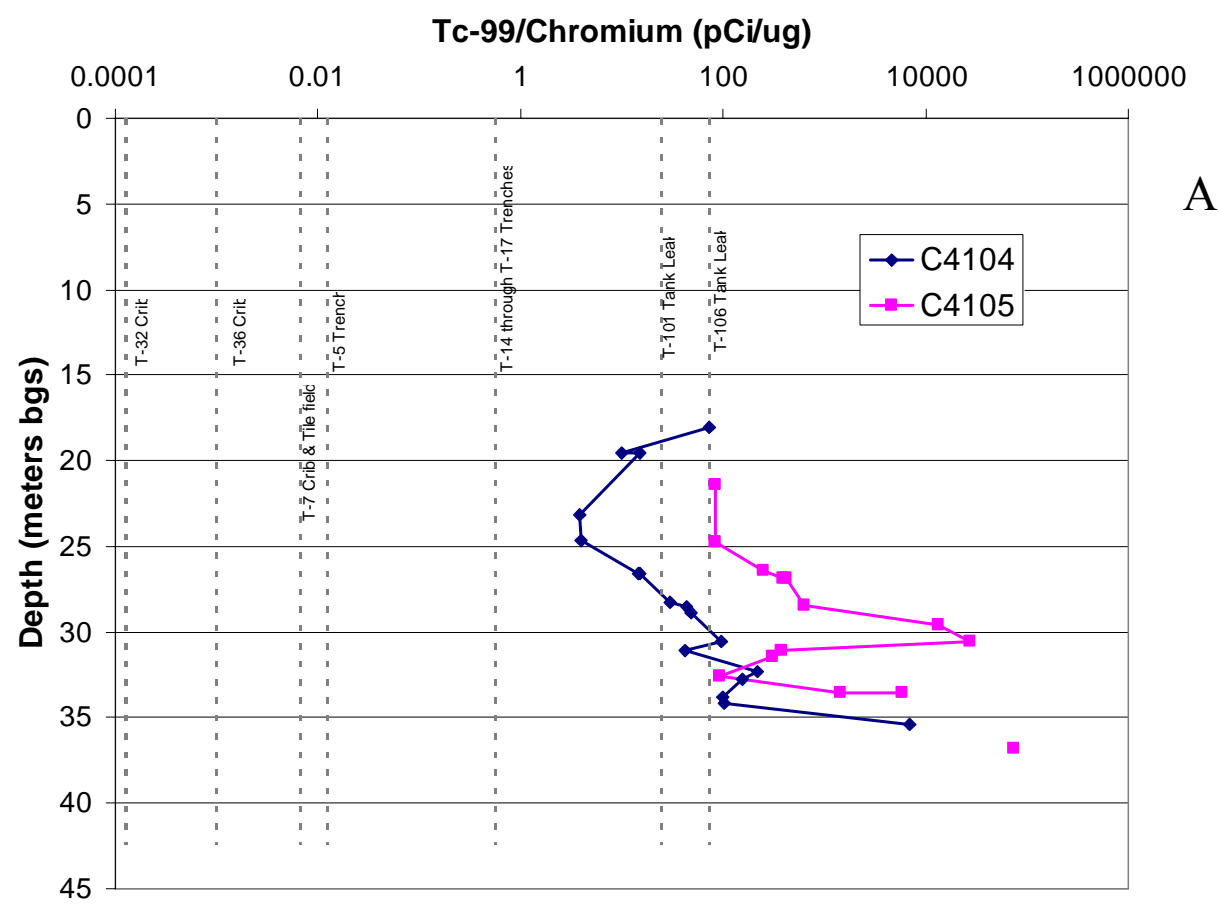

Technetium-99/Chromium (pCi/ug)

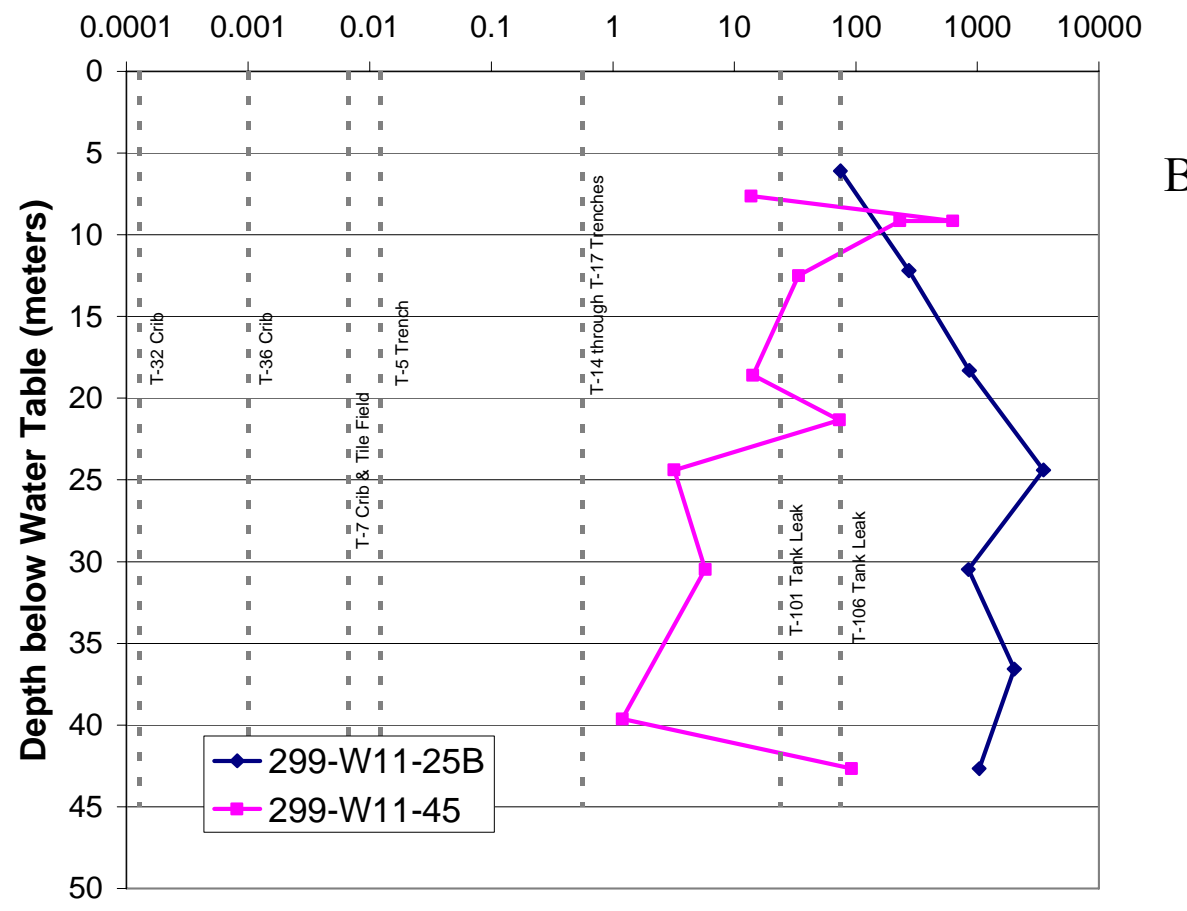

Figure 2.28. Technetium-99/Chromium Composition Ratios for A: Pore Water at the Tank T-106 Leak (Serne et al. 2004b) and B: Two New Monitoring Wells at Waste Management Area T 

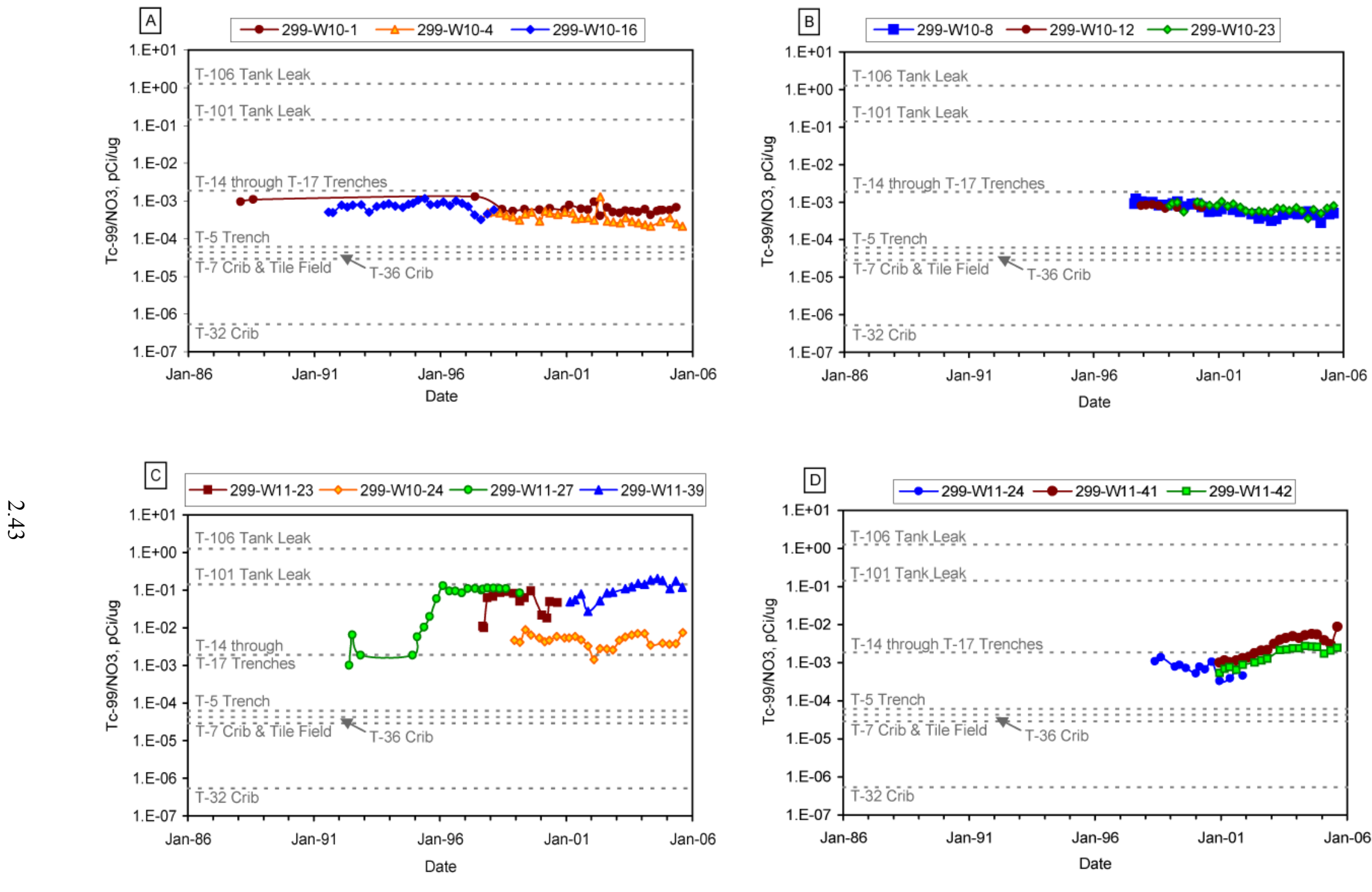

Figure 2.29. Technetium-99/Nitrate Concentration Ratios in Samples from Selected Wells at Waste Management Area T. $(A)=$ upgradient (West) wells; (B) = northern wells; (C) = northeastern wells; (D) = eastern (downgradient wells). 
Figure 2.30A shows the technetium-99/nitrate composition ratios estimated for the two tank leaks with ratios measured from vadose zone pore water associated with the tank T-106 leak (Serne et al. 2004). Figure 2.30B compares the technetium-99/nitrate ratios estimated for two tank leaks with the compositions of groundwater samples from wells 299-W11-25B and 299-W11-45. The technetium-99/ nitrate concentrations ratios are within the same order of magnitude range as are the estimated tank leak ratios and, more importantly, the sampled pore water. The tie between the technetium-99/nitrate groundwater data and the vadose zone pore water data is much tighter than for the technetium-99/chromium data. This may be the results of some retardation of chromium relative to technetium-99 in the vadose zone and aquifer.

\subsubsection{Vadose Zone Contamination}

Contaminants that reach the water table must pass through the vadose zone. Knowing the location of current vadose zone contamination provides a basis for focusing groundwater monitoring on a specific area of the WMA and may provide an explanation for groundwater contamination if it is detected. Spectral gamma logging in boreholes drilled around the single-shell tanks in WMA T is conducted to delineate the location of gamma emitting radionuclides in the vadose zone (DOE 2000a). Whereas the radioactive contaminants detectable by gamma logging are considered fairly immobile in the Hanford Site sediments, their identification provides a minimum indication of how deep the more mobile constituents may have migrated.

Figure 2.31 contains selected figures from the addendum (DOE 2000a) to the T Tank Farm spectral gamma logging report. These figures show the general distribution of gamma contamination around the tanks. The actual gamma logs are included in the logging report (DOE 2000a). The addendum and the original report can be viewed at http://www.doegjpo.com/programs/hanf/HTFVZ.html.

Figure 2.31 shows a general representation of detected contamination at progressively deeper positions beneath the ground surfaced ranging from 1.8 to 21.6 meters deep. Contaminant distribution at the 1.8-meter depth illustrates the extent of contamination at and near the surface (Figure 2.31A) and only cesium- 137 was identified at this depth. At about 6 meters depth (not shown on Figure 2.31) europium-154 is detected around tank T-103 and at 7.3 meters depth and cobalt-60 is detected in the same area (Figure 2.31B). Also, the cesium-137 between tanks T-104 and T-107 is the deepest cesium-137 associated with a surface source.

Figure $2.31 \mathrm{C}$ shows the distribution of gamma emitting contamination at 11.9 meters depth which is approximately the depth of the base of the tanks. DOE (2000a) suggests that the contamination east of tanks T-103 and T-101 is the result of leaks in fill lines and that contamination west of T-101 is the result of leaks from a cascade overfill line. The contamination at tank T-106 is associated with a leak from that tank and the contamination between tanks T-102 and T-105 is probably the result of a leak from one of those tanks. The deepest slice is from 21.6 meters depth and is about 3 meters above the contact between the Hanford formation and underlying Cold Creek unit. The Figure 2.31D shows that all of the plumes have merged at this depth and cover approximately one-third of the tank farm. 

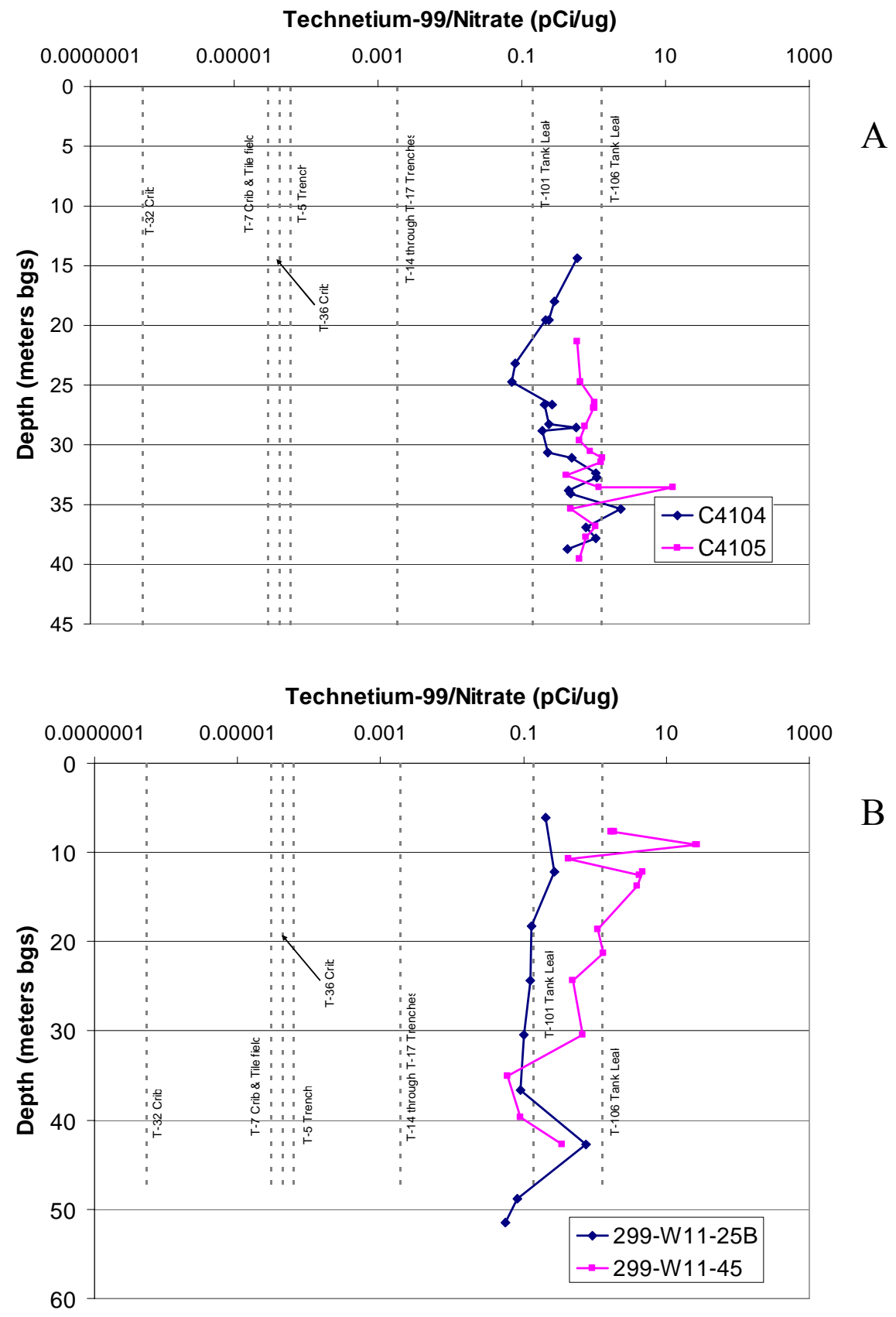

Figure 2.30. Technetium-99/Nitrate Composition Ratios for A: Pore Water at the Tank T-106 Leak and B: Two New Monitoring Wells at Waste Management Area T 


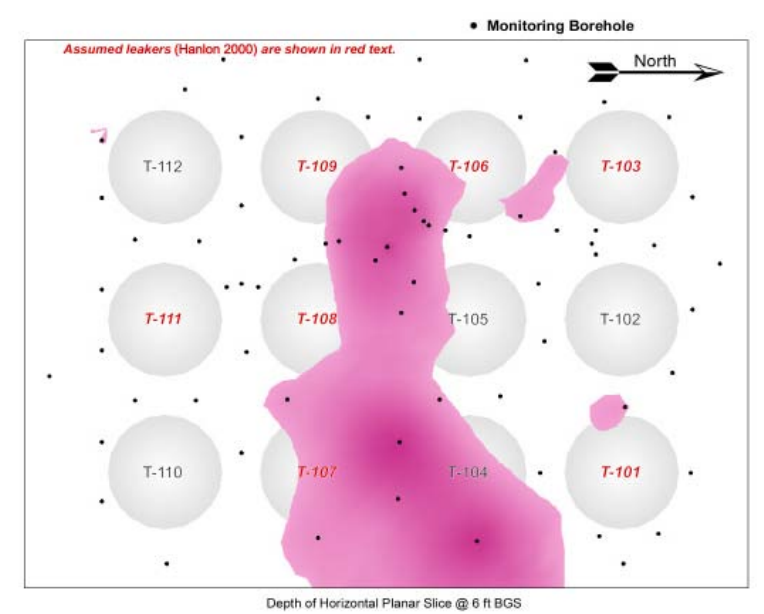

$$
\begin{gathered}
\text { Cs } 137 \text { 15olevel }=0.5 \mathrm{pClig} \\
\text { Cs. } 137 \text { Concentration (pcig) }
\end{gathered}
$$
$10^{-4} 10^{8} 10^{1} 10^{2} 10^{3} 10^{4} 10^{5} 10^{8} 10^{7}$

(A)

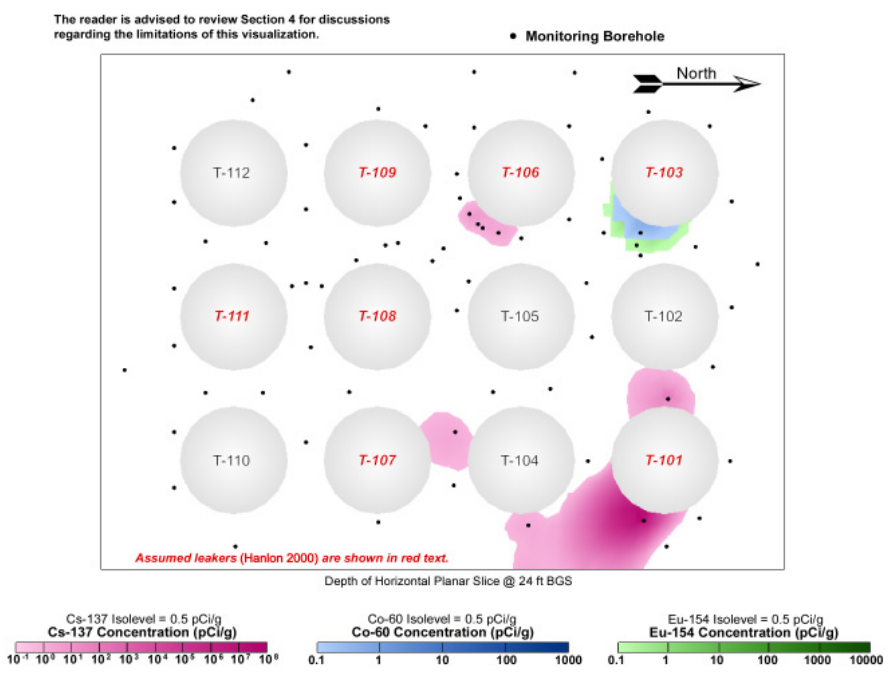

(B)

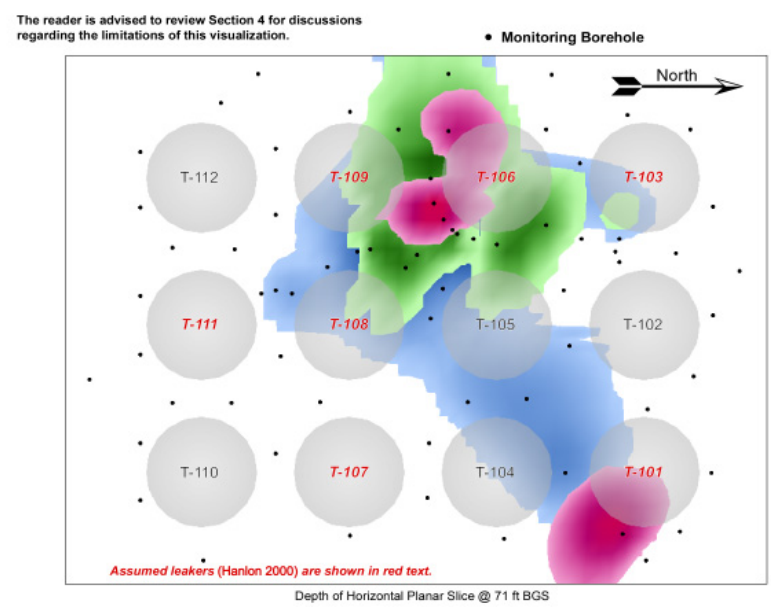

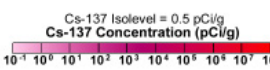

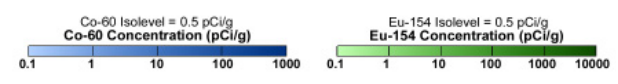

(D)

Figure 2.31. Vadose Zone Contamination in the T Tank Farm (from DOE 2000a). Note depths are given in feet below ground surface. Multiply by 0.3048 to change feet to meters. 
Repeated logging events and analysis of historical gross gamma logs both show possible contaminant movement in the subsurface between 1975 and 1994 and between 1998 and 1999. (There was no logging between 1994 and 1998.) Possible movement occurred adjacent to drywells west of tank T-101 and northeast and southeast of tank T-105. This movement may be associated with the contamination found in the groundwater at the northeast corner of the WMA. Possible movement was also found northwest of tank T-109 and west and southeast of tank T-106. The vertical extent of vadose zone contamination at WMA T is not well known because contamination extends deeper than the bottom of the drywells in which it was detected.

Several drywells and groundwater wells at the 216-T-7 crib and tile field have been periodically monitored in the past. Fecht et al. (1977) state that on the basis of scintillation logs obtained in well 299-W10-3 between 1959 and 1976, breakthrough of contaminants to groundwater could have occurred at the $216-\mathrm{T}-7 \mathrm{crib}$.

The 216-T-32 crib is monitored by eight drywells. Fecht et al. (1977) found no measurable migration of radionuclides in the vadose zone after comparing scintillation logs obtained in 1963 and 1976 and concluded that breakthrough to groundwater had not occurred at that site in 1976. 


\subsection{Data Quality Objectives}

This chapter applies the relevant components of the general DQO process as an aid in designing a cost-effective data collection plan to support decision making for the RFI/CMS and for the groundwater assessment at WMA T. The process was originally designed by the U.S. Environmental Protection Agency (EPA) to expedite cleanup activities at RCRA corrective action or superfund sites (EPA 2000). Thus, not all of the steps apply to a groundwater quality assessment. The important or essential aspects of the DQO process are that key decisions are identified in the form of questions or statements and that data acquired are appropriate to make the necessary decisions.

The process for developing DQOs involves the following seven primary steps:

1. State the problem (Section 3.1)

2. Identify the decision and expected action (Section 3.2)

3. Identify decision inputs (Section 3.3)

4. Define the study boundaries (Section 3.4)

5. Develop decision rules (Section 3.5)

6. Specify limits on decision errors (not applicable to groundwater monitoring plans)

7. Optimize the sampling design (Section 3.6).

\subsection{Statement of the Problem}

The problem addressed by this DQO is the uncertainties in the conceptual model pertaining to determination of (1) contaminant source, (2) groundwater flow rate and flow direction, (3) lateral and vertical contaminant distributions, (4) driving forces to move contaminants to groundwater, and

(5) contaminant pathways to groundwater.

These uncertainties in the conceptual model of WMA T are discussed in this section.

\subsubsection{Scoping Process}

The scoping process gathers the information that will be used to develop the conceptual model of WMA T. Such information includes the following items:

- History of operations at WMA T

- Waste characteristics

- Characterization of existing vadose zone and groundwater contamination

- Site geology and hydrology

This information was discussed in Chapter 2.0 as background information to refine the conceptual model and define problem statements and key issues. 


\subsubsection{Regulatory Drivers}

WMA T is regulated under RCRA interim-status regulations (40 CFR 265, Subpart F) and Washington's HWMA (RCW 70.105). Implementing requirements are provided in Washington's Dangerous Waste Regulations (WAC 173-303). The site was originally placed in groundwater assessment monitoring status (40 CFR 265.93 [d]) in 1993 because specific conductance values in downgradient well 299-W10-15 exceeded the upgradient background value of 1,175 $\mu \mathrm{S} / \mathrm{cm}$ (Caggiano and Chou 1993). In 1996, specific conductance exceeded the critical mean in well 299-W11-27 and was accompanied by increases in the concentrations of nitrate, calcium, magnesium, sulfate, chromium, technetium-99, and cobalt-60.

The first assessment report (Hodges 1998) did not identify an upgradient source for the contamination observed in monitoring well 299-W11-27 and did find evidence linking the contaminants in groundwater to the WMA. As a result, a revised assessment plan was written (Hodges and Chou 2001) to guide the investigation of the rate and extent of aquifer contamination beneath the WMA. This plan updates the revised assessment plan (Hodges and Chou 2001).

This DQO considers both RCRA regulated dangerous waste constituents and certain non-RCRA regulated constituents to satisfy the integration of the RCRA groundwater quality assessment with the CERCLA 200-ZP-1 groundwater operable unit remedial investigation and the RCRA vadose facility investigation/corrective measures study. This provides comprehensive interpretations of groundwater contamination.

Groundwater monitoring objectives of RCRA, CERCLA, and the AEA often differ slightly and the contaminants monitored are not always the same. For RCRA regulated units, monitoring focuses on nonradioactive dangerous waste constituents. Radionuclides (source, special nuclear and by-product materials) may be monitored in some RCRA unit wells to support objectives of monitoring under the AEA and/or CERCLA. Please note that pursuant to RCRA, the source, special nuclear and by-product material component of radioactive mixed waste are not regulated under RCRA and are regulated by DOE acting pursuant to its AEA authority. Therefore, while this report may be used to satisfy RCRA reporting requirements, the inclusion of information on radionuclides in such a context is for information only and may not be used to create conditions or other restrictions set forth in any RCRA permit.

\subsubsection{Conceptual Model for Waste Management Area T}

This section describes the current conceptual model for WMA T. This model will be modified as new data become available and new understanding is developed. The current conceptual model for WMA T illustrates the complexity and the spatial and temporal relationships of five important parameters: contaminant sources, driving forces, migration pathways to groundwater, changes in groundwater flow direction and flow rate, and the current contaminant distributions in the aquifer. The model described in this section is a synthesis of the information given in Chapter 2.0. 


\subsubsection{Contaminant Sources}

Several potential sources for groundwater contamination exist in the WMA T area:

- Tank leaks

- Liquid wastes disposed to past-practice facilities located northeast, west, and southwest of the WMA T

- Unplanned releases including leaking pipelines

- Regional contamination from far-field sources (e.g., Plutonium Finishing Plant)

Each of these potential sources is discussed in Chapter 2.0. It currently is not possible to distinguish sources within WMA T from sources outside the WMA in instances where tank waste was purposely discharged to nearby, past practice facilities.

There are regional sources for most of the tritium, carbon tetrachloride, and nitrate found in the groundwater beneath WMA T with the exception of a probable local source for the extremely high nitrate near well 299-W10-4 and the high nitrate concentrations associated with technetium-99 found in well 299-W11-25B. Results shown in Chapter 2.0 indicate that (1) tank waste from the WMA has impacted groundwater at the northeast corner and along the eastern boundary of the WMA and (2) past-practice cribs, trenches, and tile fields, located west of WMA T, have impacted groundwater west and north of the WMA and may be impacting groundwater east of the WMA. The most likely source for the tank waste in groundwater northeast and east of WMA T is the WMA itself and may be the relatively small 1969 leak from tank T-101, although impact from the T-106 leak is possible.

All tanks in WMA T have been interim stabilized, which means each tank contains less than 189,000 liters of drainable liquid and less than 18,900 liters of supernate (Hanlon 2004). Consequently there is little risk that large, new leaks will occur from the tanks. However, a total of 810,000 liters of drainable interstitial liquid and 102,000 liters of supernate remain in all of the tanks with four tanks still containing greater than 114,000 liters of drainable liquid so the possibility of future impacts to groundwater remains.

Spectral gamma ray logging in WMA T has shown that there are substantial amounts of cesium-137, cobalt-60, and europium-152, -154 with minor amounts of tin-126, antimony-125, and uranium-235, -238 in the vadose zone (DOE 2000a). Although these constituents are relatively immobile in the vadose zone environment (except cobalt-60 and possibly uranium), their presence indicates that more mobile (and non-gamma ray emitting) contaminants such as nitrate, chromium, and technetium-99 are probably also present. Therefore, most future tank waste contamination in the groundwater is expected to result from either remobilization of residual vadose zone plumes or leaks associated with liquid waste transfers and single-shell tank remediation.

All non-permitted, liquid discharges were terminated at the Hanford Site in 1995. Therefore, no flushing of contaminants to groundwater will result from future intentional discharges. However, residual vadose zone pore water and associated contaminants remain in the vadose zone beneath 
past-practice disposal facilities and WMA T. This residual contamination is expected to slowly bleed into the aquifer for the foreseeable future under the influence of natural infiltration.

Non-tank sources have contributed to groundwater contamination in the past. The earliest evidence of groundwater contamination is high levels of gross beta in wells located at the cribs and trenches west of WMA T in 1955 (Serne et al. 2004). This early groundwater contamination pre-dates any reported tank leak from the T Tank Farm.

\subsubsection{Driving Forces}

In general, there are two ways to transport contaminants to groundwater. The first is associated with very large leaks when the amount of liquid is sufficient to reach groundwater through gravitational forces and capillary action. The second is associated with an external source of water (or other liquid) available to remobilize residual waste in vadose zone plumes. Since most tanks in WMA T no longer contain large amounts of liquid waste and since large volume disposal to cribs and tile fields no longer takes place, it is unlikely that a sufficient source of liquid large enough to reach groundwater unassisted will exist at WMA T.

The second mechanism is to move existing vadose zone contamination to groundwater. This involves an external source of water and is the most likely possibility at WMA T. The most likely external sources are broken water lines and natural precipitation. Broken water lines can produce large volumes of water, however, all known water lines in the area have been pressure tested and all unnecessary water lines have been turned off and capped. It is possible but unlikely that a previously unidentified water line will leak and substantially mobilize existing vadose zone contamination to groundwater in the area.

As discussed in Chapter 2.0, there is evidence that a broken waste water transfer line may have leaked considerable water and locally affected the composition of the groundwater near the northeast corner of the WMA during the first half of the 1990s. This leak may also be partly responsible for the relatively deep contamination that was recently found in well 299-W11-25B.

Remobilization of vadose zone waste also can occur as a result of heavy rainfall and sudden snowmelt. Johnson and Chou (1998) discuss the extent that rapid snowmelt from recent years has contributed to increased infiltration at WMA S-SX. A rapid snow melt in February 1979 caused extensive flooding in the T Tank Farm (Hodges 1998). The detrimental effects of natural recharge can be enhanced by gravel surfaces, lack of vegetation, and the presence of surface depressions that collect and pond runoff and snow melt. Recently, berms have been constructed around the T Tank Farm to eliminate run-on from adjacent areas so extensive flooding such as that of February 1979 should not occur in the future.

The surface of the tank farm is covered with gravel and kept free of vegetation. Recently, Gee and Ward (2002) used a water balance model based on surface sediment texture and the past 20-year climate record to predict the amount of annual drainage in selected tank farms. Drainage estimates from the model suggest an annual drainage of 28 to 56 millimeters/year for the U Tank Farm and the S Tank Farm in 200 West Area. No analysis was specifically made for the T Tank Farm but surface conditions are similar. 


\subsubsection{Migration Pathways}

The water table at WMA T is approximately 69 to 81 meters below the surface. Because the vadose zone is so thick, much of the migration pathway from a near-surface source to a groundwater monitoring well will be in the unsaturated zone. Liquid migration through the unsaturated zone is highly dependent on heterogeneities and anisotropy in the sediment. The sediments making up the vadose zone beneath WMA T consist of moderate to high-energy Hanford formation flood deposits with a large variability in grain size and grain sorting; the Cold Creek unit with variable caliche development; and Ringold Formation member of Taylor Flats and member of Wooded Island unit E with variable grain size, grain sorting, cementation, and compaction. These variabilities occur at scales of centimeters to meters. Consequently, it is not realistic to define specific migration pathways through the vadose zone beneath WMA T.

The sediment layer with the most influence on moisture migration through the vadose zone is the Cold Creek unit. The relatively low permeability of the Cold Creek unit has two important effects on migration of moisture through the vadose zone. First, the fine-grained nature of the Cold Creek silt unit requires that it essentially become saturated before moisture breakthrough to underlying units. This tends to lengthen the time required for moisture to reach the water table and results in lateral spreading of moisture and contamination. Second, the cemented Cold Creek caliche unit tends to pond water locally in several places beneath the $200 \mathrm{West}$ Area. This also lengthens the time required for moisture to reach the water table and results in lateral migration.

Clastic dikes are sub-vertical, sedimentary features that crosscut existing horizontal bedding. Recent work by Ward et al. (2004) shows that at low water fluxes the fine-textured region of clastic dikes dominate flow, at intermediate fluxes both the coarse sand host matrix and the fine-textured regions contribute to flow, and at high input fluxes the coarse-textured host sediments dominate flow.

Clastic dikes exist in the subsurface at several areas of the Hanford Site and have been documented at T Tank Farm (Price and Fecht 1976; Fecht et al. 1999). Clastic dikes also have been noted at the other tank farms in 200 West Area and in drill core from wells in the area (C3102 at the 216-T-26 crib, 299-W22-48 at the WMA S-SX, 299-W23-16 at the 216-U-14 ditch, and 299-W10-22 at the 216-T-4-2

ditch). Several clastic dikes are known to extend at least 20 meters into the subsurface and the maximum vertical extent known for a clastic dike is about 45 meters.

Another feature that can act as a preferential, vertical pathway is the outside of casings of wells and boreholes with no, or poorly constructed, annular seals. There is documentation that 45 of the 67 drywells in the T Tank Farm (Chamness and Merz 1993), used for secondary leak detection, have been modified since they were drilled to retrofit an annular seal in an effort to prohibit downward migration of fluids along the outside of the casing. There is no documentation in Chamness and Merz (1993), the Hanford Well Information System, or the PNNL well library that the remaining 22 drywells have an annular seal. Most drywells were drilled between 15.2 to 45.7 meters deep and the water table beneath WMA T is about 69 to 81 meters below ground surface. Thus, there is about 23 to 35 meters of vadose zone between the bottom of the deepest drywells and the water table.

All WAC 173-160 compliant monitoring wells at WMA T have annular seals. However, groundwater monitoring wells 299-W10-8 through 299-W10-12, located on the north side of the WMA, and (now dry) well 299-W11-23, located at the northeast corner of the tank farm, are older 14.9-centimeters 
diameter carbon-steel-cased wells. The as-built diagrams for these wells have no documentation concerning annular seals. These wells are potential preferential pathways for any contaminants that encountered the wells in the past or may encounter the wells in the future.

Field studies at the Hanford Site suggest that relatively narrow, vertical zones of moisture can flow through unsaturated sediment. Gee and Ward (2001) describe infiltration tests with different ionic strength fluids and how the fluid properties influence formation of moisture "fingers." Once such vertical pathways are established by an initial infiltration event, subsequent infiltration events will prefer the same channels.

Further evidence to support this type of flow behavior comes from direct observation of infiltration tests performed at the 105A mock tank site, 200 East Area (Narbutovskih et al. 1996). Electrical resistivity tomography was used at that site to track leaked saline water, as fingered flow, from the surface to a depth of about 21 meters. Furthermore, analysis of the infiltration rate, time to reach depth, and total volume of leaked fluid indicated that a low-volume, point leak might reach groundwater in that area within a few months (Hartman and Dresel 1997). This estimate, however, is for a part of 200 East Area where the vadose zone consists of only the Hanford formation. The travel time to groundwater beneath WMA T is expected to be somewhat larger because the less permeable Cold Creek Unit and Ringold Formation Unit E gravels make up the lower part of the vadose zone under much of north-central 200 West Area.

\subsubsection{Changing Groundwater Flow Direction}

Historical changes in groundwater flow direction were discussed in Section 2. Using the general flow directions from Figure 2.9 and the water-table gradients in Reidel et al. (2005) and assuming an average hydraulic conductivity of 2.5 meters/day (within the range given in Table 2.7) and an effective porosity of 0.2 , groundwater could have traveled and carried contaminants from WMA T or other nearby sources approximately (1) 34 meters toward the south between 1954 and 1957, (2) 170 meters northeast between 1957 and 1982, (3) 110 meters north or northwest between 1983 and 1995, and (4) 32 meters toward the east between 1997 and 2004. (The earliest reported tank leak at WMA T is tank T-106 in 1973.) Although these distances are estimates, they show that changes in the groundwater flow direction could have contributed to relatively widespread contaminant distribution.

\subsubsection{Contaminant Distribution}

Section 2.6 discusses the vertical concentration gradients for certain contaminants in places at WMA T. Concentrations increase with depth in the aquifer in some places and decrease with depth in other places. Section 2.6 also provided information about the known lateral extent of contamination at WMA T. The lateral extent is not well known downgradient of the WMA. The eastern extent of the contamination found in the downgradient wells is not defined.

\subsubsection{State the Problem}

The problems addressed by this DQO are the uncertainties in the conceptual model which are summarized in Table 3.1. 
Table 3.1. Summary of Problem Statement

\begin{tabular}{|c|c|c|}
\hline & Problem Statement & Source of the Problem \\
\hline 1 & $\begin{array}{l}\text { The source or sources for contamination at } \\
\text { WMA T are not well known. }\end{array}$ & $\begin{array}{l}\text { Multiple potential sources include tank leaks, spills, } \\
\text { transfer pipelines, adjacent cribs and trenches. }\end{array}$ \\
\hline 2 & $\begin{array}{l}\text { Groundwater flow rate and direction at WMA T } \\
\text { have changed through time. }\end{array}$ & $\begin{array}{l}\text { Groundwater flow rate and direction are required by } \\
40 \text { CFR } 265.93(d)(4)(i) \text { and WAC 173-303-400. }\end{array}$ \\
\hline 3 & $\begin{array}{l}\text { The mechanism(s) driving contamination to } \\
\text { groundwater at WMA T are not well defined. }\end{array}$ & $\begin{array}{l}\text { Potential driving forces include natural infiltration, } \\
\text { past intentional disposal to ground, and water line } \\
\text { leaks. Elimination of driving forces mitigates further } \\
\text { contamination of groundwater from vadose zone } \\
\text { sources. }\end{array}$ \\
\hline 4 & $\begin{array}{l}\text { The lateral and vertical distributions of contami- } \\
\text { nation in groundwater at WMA T are not well } \\
\text { known. }\end{array}$ & $\begin{array}{l}\text { The extent of contamination is required by } 40 \text { CFR } \\
265.93(d)(4)(i) \text { and WAC } 173-303-400 \text {. }\end{array}$ \\
\hline 5 & $\begin{array}{l}\text { The dangerous waste contaminants in groundwater } \\
\text { at WMA T are well defined at monitoring well } \\
\text { locations but the concentrations change with time. }\end{array}$ & $\begin{array}{l}\text { The concentrations of dangerous waste constituents } \\
\text { is required by } 40 \text { CFR } 265.93(\mathrm{~d})(4)(\mathrm{i}) \text { and } \\
\text { WAC } 173-303-400 .\end{array}$ \\
\hline 6 & $\begin{array}{l}\text { The pathway(s) for contaminant migration to } \\
\text { groundwater at WMA T are not well defined. }\end{array}$ & $\begin{array}{l}\text { The natural pathways to groundwater are through a } \\
\text { heterogeneous and anisotropic unsaturated zone. } \\
\text { Man-made pathways include poorly constructed wells } \\
\text { and boreholes. Eliminating or inhibiting migrations } \\
\text { pathways mitigates further contamination of ground- } \\
\text { water from vadose zone sources. }\end{array}$ \\
\hline
\end{tabular}

\subsection{Identify Decisions}

The decision statements identified below are regulatory driven as stated in 40 CFR 265.93(d)(4)(i) and (ii) [and by reference WAC 173-303-400] and as indicated in the Technical Enforcement Guidance Document (EPA 1986). The primary information needed for the ongoing groundwater quality assessment at WMA $\mathrm{T}$ is the information to make the following decisions.

1. Determine if the compliance well network is consistent with the rate and direction of groundwater flow and, therefore, requires no action or if the compliance well network is inconsistent with the rate and direction of groundwater flow and, therefore, requires modification. (Addresses problem statements 2 and 4.)

2. Determine whether changes in concentrations of dangerous waste constituents in the groundwater originating from the regulated unit are well defined by the existing sampling frequency, in which case no change in the sampling schedule is required, or whether changes in concentrations are not well defined, requiring an increase in sampling frequency. (Addresses problem statement 5.)

Additional information is needed to support decisions concerning facility and groundwater remediation activities at WMA T. This information is the data needed to address the following decision statements.

3. Determine whether the source or sources of groundwater contamination beneath WMA T are adequately identified, requiring no change in the assessment well network, or if the source or 
sources of groundwater contamination are not adequately identified, requiring modification of the well network. (Addresses problem statement 1.)

4. Determine whether identified driving forces account for migration of contamination through the vadose zone to groundwater, requiring no action, or whether driving forces for contaminant migration are not well understood, requiring modification to the assessment well network or additional studies. (Addresses problem statement 3.)

5. Determine whether the pathways that allowed contamination to traverse the vadose zone and enter groundwater at WMA T are adequately known, requiring no action, or whether the pathways for contaminant migration are not well identified, requiring modification to the assessment well network or additional studies. (Addresses problem statement 6.)

The information needed to make these decisions is discussed in Section 3.3.

\subsection{Decision Inputs}

This section describes the information needs for addressing the general decisions and site-specific questions identified above. A summary of the information needs is given in Table 3.2. More detailed discussion of the information needs is given in the sections following Table 3.2.

\subsubsection{Groundwater Flow Rate and Direction}

The rate and direction of groundwater flow is fundamental to assessing the rate of migration and extent of groundwater contamination from the assumed source. Placement of new wells to enhance the likelihood of detecting contaminant plumes and estimating the arrival times at some point of potential exposure (or point of compliance) depend on knowing the rate and direction of groundwater flow.

\subsubsection{Data Needs and Approach}

The flow rate and flow direction where tank waste constituents have been observed in groundwater need to be determined.

This fundamental information must be acquired by investigative techniques based on field measurements.

Flow Rate. Flow rate is a fundamental parameter for predicting plume movement and distribution. The configuration of wells in the monitoring network at WMA T is not conducive to measurement of flow rate using multi-well methods such as tracer tests.

Instead, the more classic method to estimate flow rate, using the Darcy equation, will be done. This approach is based on hydraulic conductivity of the aquifer in combination with the water-table gradient and effective porosity. The effective porosity and hydraulic conductivity have been estimated from the results of aquifer tests (slug tests, tracer tests, and pumping tests) in several wells at WMA T. The watertable gradient is determined from water-level measurements. Water-level measurements are collected quarterly at WMA T. 
Table 3.2. Required Information and Sources

\begin{tabular}{|c|c|c|c|}
\hline $\begin{array}{c}\text { Decision } \\
\text { Statement }^{(a)}\end{array}$ & Variable & Required Information & Source \\
\hline \multirow[t]{2}{*}{1} & \multirow[t]{2}{*}{$\begin{array}{l}\text { Groundwater flow } \\
\text { rate }\end{array}$} & Calculated groundwater flow rate & $\begin{array}{l}\text { Hydraulic conductivity, effective porosity, and } \\
\text { water-table gradient }\end{array}$ \\
\hline & & $\begin{array}{l}\text { Hydraulic conductivity, effective } \\
\text { porosity, and water-table gradient }\end{array}$ & $\begin{array}{l}\text { Hydraulic properties exist from aquifer testing; } \\
\text { additional aquifer testing will be done at newly } \\
\text { installed wells. Water-table gradient determined } \\
\text { from water level measurements. }\end{array}$ \\
\hline 1 & $\begin{array}{l}\text { Groundwater flow } \\
\text { direction }\end{array}$ & Water-table elevations & Quarterly and annual water level measurement. \\
\hline \multirow[t]{4}{*}{1} & \multirow[t]{4}{*}{$\begin{array}{l}\text { Lateral extent of } \\
\text { contamination }\end{array}$} & $\begin{array}{l}\text { Groundwater flow rate and flow } \\
\text { direction }\end{array}$ & See above. \\
\hline & & Groundwater chemical composition & $\begin{array}{l}\text { Concentrations are determined from quarterly, } \\
\text { semi-annual, and annual (depending on constitu- } \\
\text { ent) groundwater sampling and analysis }\end{array}$ \\
\hline & & New monitoring wells & $\begin{array}{l}\text { One new monitoring well will be drilled about } \\
80 \text { m downgradient of WMA T. Additional wells } \\
\text { require prioritization through the well drilling } \\
\text { DQO. }\end{array}$ \\
\hline & & $\begin{array}{l}\text { Contaminant distribution } \\
\text { coefficients }\end{array}$ & $\begin{array}{l}\text { Distribution coefficients exist for several contami- } \\
\text { nants (Cantrell et al. 2002). }\end{array}$ \\
\hline \multirow[t]{2}{*}{1} & \multirow[t]{2}{*}{$\begin{array}{l}\text { Vertical extent of } \\
\text { contamination }\end{array}$} & Groundwater chemical composition & $\begin{array}{l}\text { Depth discrete groundwater samples will be } \\
\text { collected from existing and new wells. }\end{array}$ \\
\hline & & New monitoring wells & $\begin{array}{l}\text { Two new monitoring wells will be drilled to } 36.57 \\
\mathrm{~m} \text { below the water table or to the Ringold } \\
\text { Formation lower mud unit in calendar year } 2005 \text {. } \\
\text { Additional wells require prioritization through the } \\
\text { well drilling DQO. }\end{array}$ \\
\hline 2 & $\begin{array}{l}\text { Contaminant } \\
\text { concentrations }\end{array}$ & $\begin{array}{l}\text { Concentrations of contaminants in } \\
\text { groundwater. }\end{array}$ & $\begin{array}{l}\text { Concentrations are determined from (1) quarterly, } \\
\text { semi-annual, and annual (depending on constitu- } \\
\text { ent) groundwater sampling and analysis and } \\
\text { (2) analysis of depth discrete groundwater samples. }\end{array}$ \\
\hline \multirow[t]{4}{*}{$3,4,5$} & \multirow{4}{*}{$\begin{array}{l}\text { Contaminant } \\
\text { source(s), driving } \\
\text { forces, and } \\
\text { migration } \\
\text { pathways }\end{array}$} & $\begin{array}{l}\text { Lateral and vertical contaminant } \\
\text { distribution }\end{array}$ & See above. \\
\hline & & Contaminant concentrations & See above. \\
\hline & & Isotopic signatures & $\begin{array}{l}\text { Analyses of groundwater samples for Ru- } 101 \text {, } \\
-102 \text {, and }-104 \text {; Sr- } 87 / \mathrm{Sr}-86 \text {; N-15 and } \mathrm{O}-18 \text { in } \\
\text { nitrate; uranium isotopes; and stable chromium } \\
\text { isotopes. }\end{array}$ \\
\hline & & Possible new wells. & $\begin{array}{l}\text { Any new wells needed to differentiate contaminant } \\
\text { sources require prioritization through the well } \\
\text { drilling DQO }\end{array}$ \\
\hline \multicolumn{4}{|c|}{$\begin{array}{l}\text { (b) } \mathrm{DQO}=\text { Data quality objectives. } \\
\text { (c) } \mathrm{WMA}=\text { Waste management area. }\end{array}$} \\
\hline
\end{tabular}


Additional hydrologic data will be collected from new boreholes by conducting several aquifer tests. These data will result in additional estimates of groundwater rate and flow direction. The aquifer tests to be performed and the resulting data include the following:

- Slug tests - preliminary hydraulic conductivity.

- Tracer-dilution tests - vertical distribution of hydraulic conductivity and/or groundwater flow velocity within the well screen section and vertical flow within the well screen section.

- Tracer-pumpback tests - effective porosity.

- Pumping Tests - hydraulic conductivity, storativity, and specific yield.

Multiple well pumping tests will be done where well configurations are appropriate.

Flow Direction. Groundwater flow direction will be inferred from water-table elevations in available wells. This approach depends on accurate depth-to-water measurements. Barometric corrections will be conducted if needed. Reliable casing elevations will be obtained or assessed based on available information.

The water-level measurements will be used to map the flow direction in the vicinity of WMA T after depth-to-water corrections are made. The current estimate of flow direction is shown in Figure 2.10.

A second method to estimate flow direction will be applied to the corrected depth-to-water measurements. A series of three point problems will be applied to several series of water-level measurements. The three point problem is a typical analysis used in earth science to determine the orientation of a plane in space.

\subsubsection{Data Uses}

The flow rate and flow direction are necessary input to the proper placement of monitoring wells for understanding the extent of contamination at WMA T. The uses of this input are described in Section 3.3.2.

\subsubsection{Extent of Contamination}

The spatial and vertical distribution of contaminants in the aquifer is required by 40 CFR 265.93(d)(4)(i) and provides indications of the nature of the vadose zone source, the driving forces and likely transport processes through the vadose zone and groundwater, input to risk assessments, and information supporting corrective measures and remediation.

\subsubsection{Lateral Extent of Contamination}

The lateral extent of contamination from WMA T will be estimated using plume maps and simple numeric models. 


\section{Data Needs and Approach}

\section{The lateral extent of contamination in the aquifer needs to be determined.}

This fundamental information must be acquired by investigative techniques based on field measurements and analytical laboratory data obtained from monitoring wells. These data need to be integrated with historical groundwater compositions and historical groundwater flow characteristics.

Groundwater Flow Rate and Flow Direction. The groundwater flow rate and flow direction are input obtained from the decision inputs described in Section 3.3.1.

Groundwater Chemical Composition. Analyses of routinely collected groundwater samples are necessary to know the concentrations of contaminants and to estimate the lateral extent of contamination. The samples are collected from all wells in the monitoring network quarterly, semi-annually, or annually (depending on constituent). Samples are collected by pump after purging three well volumes and after stabilization of $\mathrm{pH}$, specific conductance, temperature, and turbidity. Sample collection, storage, and transportation are done by subcontractors to the Hanford Groundwater Performance Assessment Project according to specifications in a statement of work to the subcontractor. Sample analyses are routinely done by subcontracted laboratories. Analytical procedures are based on EPA-approved methods or, in the case of radionuclides, on laboratory-specific procedures based on best laboratory practice. The analytical data are used to construct contaminant plume maps. The extent to which a plume map reflects the actual plume depends heavily on the distribution of monitoring wells.

Placement of Monitoring Wells. The current groundwater monitoring network at WMA T consists of 14 wells (Figure 2.23). Six new downgradient monitoring wells and one new upgradient well have been installed at the since 1998 .

\section{Monitoring wells must be strategically located to delineate contaminant plumes coming from the regulated unit.}

In 2003, a DQO study was done with the Hanford Groundwater Performance Assessment Project DOE, and the regulatory agencies that determined the number and approximate locations of two wells at WMA T (Byrnes and Williams 2003). Those wells were intended to complete the groundwater detection and assessment network for the tank farm.

One of the wells, 299-W11-25B, was installed early in 2005. That well was initially to be drilled to 36.6 meters below the water table and sampled every 1.5 meters throughout the drilled part of the aquifer to assess the vertical distribution of contaminants at the northeast corner of the WMA. High levels of contamination encountered during drilling resulted in the well being deepened to the Ringold Formation lower mud unit. (Well 299-W11-25B was damaged during construction and replaced with well 299-W11-46.) The high levels of contamination and the depth distribution of the contamination resulted in relocation of the second well identified in the DQO study closer to the WMA and addition of a third well to be located adjacent to existing well 299-W11-41. Both new wells are to be drilled to the lower mud unit in calendar year 2005. 
Based on the current understanding of the contaminant distribution at WMA T, the current groundwater monitoring network, including the two proposed wells, is probably not adequate to describe the lateral extent of contamination. The need for additional wells will be determined by the DOE and regulatory agencies after analytical results from the two proposed wells are available.

Contaminant Distribution Coefficients. The groundwater flow rate can approximate the migration of some highly mobile contaminant species. However, almost all contaminants are retarded somewhat with respect to water as they migrate through the aquifer. Adsorption is one of the primary mechanisms that control or retard the migration of many contaminants in the vadose zone and groundwater. The most common method used to describe contaminant adsorption on soil and sediment is the distribution coefficient. Distribution coefficients are experimentally derived. A catalog of available distribution coefficients recently has been published (Cantrell et al. 2002). Distribution coefficients are available for cobalt, cesium, strontium, chromium, iodine, nitrate, technetium, and other contaminants. The distribution coefficients are used to calculate retardation factors for contaminant flow and transport modeling purposes.

\section{Data Uses}

The analytical results from groundwater sample and analysis are used to construct contaminant plume maps illustrating contaminant distributions. These maps are produced quarterly and published annually for chromium, nitrate, uranium, carbon tetrachloride, trichloroethene, fluoride (annual only), sulfate (annual only), iodine-129, technetium-99, strontium-90, and tritium. The quarterly and annual maps typically show contaminant concentrations at the water table depth. Plume maps for additional analytes can be made if necessary.

Plume maps are also an aid in identification of source areas in cases where distinct plumes emanate from specific facilities.

The extent of contaminant plumes can be modeled using the simple, two-dimensional analytical transport model of Domenico and Robbins (1985). The model assumes that a solute is released along a continuous line source in a uniform aquifer, and predicts the concentrations that would be observed at points downstream of the source. Inputs to the model include the width of the source, the longitudinal and transverse dispersion coefficients, time, hydraulic conductivity, groundwater gradient, effective porosity, and retardation factors.

Retardation factors determined from experimental measured distribution coefficients are input to calculating retardation factors used in the plume generation model. The relationship is $R=1+\left(\mathrm{K}_{d} \rho_{b}\right) / \theta$, where $R$ is the retardation factor, $K_{d}$ is the distribution coefficient, $\rho_{b}$ is the bulk density, and $\theta$ is the volumetric water content.

\subsubsection{Contaminant Depth Distribution}

The vertical extent of contamination at WMA T will be determined from sample and analysis of groundwater in both the laboratory and field. 


\section{Data Needs and Approach}

\section{The vertical extent of contamination in the aquifer needs to be determined.}

This fundamental information must be acquired by investigative techniques based on field measurements and analytical laboratory data described below.

Groundwater Chemical Composition. Samples to describe lateral contaminant distribution are collected by purging a well and then pumping the samples after the well has been completed. Samples collected for vertical contaminant distribution are collected at specific depth intervals in the aquifer typically during drilling. Wells drilled deep into the aquifer can be screened at depth during well completion. Sampling of wells screened at depth can help define the vertical extent of contamination.

Depth discrete groundwater samples will be collected from each new well drilled as part of the WMA T groundwater assessment. The number of samples to be collected and the method of sampling will depend on the drilling technique.

Depth discrete geochemical information also will be collected from selected existing boreholes. Specific candidate wells in or near WMA T are wells that have recently (or currently) exceeded the drinking water standard for chromium $(100 \mu \mathrm{g} / \mathrm{L})$ and nitrate $(45 \mathrm{mg} / \mathrm{L})($ and technetium-99 [900 pCi/L] in support of tank farm corrective measures) are 299-W11-39, 299-W11-41, 299-W11-42, 299-W10-28, and 299-W10-4.

Initially, an electrical conductivity profile will be obtained to establish whether vertical concentration gradients exist in the screened intervals of the wells. If gradients exist, a discrete depth sampler will be used to collect additional data. The approach is to sample multiple depths throughout the screened interval with the shallowest sample collected as near the water table as possible ( 0 to 4 centimeters).

\section{Data Uses}

The analytical data will be used to make concentration versus depth profiles for each tested well. If sufficient profiles are made, cross-sections can be made of contaminant distribution in the aquifer.

The depth distribution of contaminants may help infer the size of the plume and distance of the contaminant source from the wells and provide inputs to remedial decisions. For example, a large utility line leak that mobilizes contaminants by localized saturated flow may result in a deeper contaminant

distribution in the aquifer than mobilization by slowly migrating moisture from natural infiltration. Also, a deeper contaminant distribution is expected from vertical dispersion from distal sources whereas a shallow contaminant plume is expected from proximal sources.

The depth distribution of contaminants is basic information needed by the regulatory agencies and DOE to make decisions concerning remedial actions and risk assessments.

\subsubsection{Contaminant Concentrations}

The concentrations of contaminants in the uppermost aquifer need to be determined. 


\section{Data Needs and Approach}

The results of groundwater sampling and analysis are the data needed to determine the concentrations of contaminants in the aquifer. These are the same data needs described above for determining the lateral and vertical extent of contamination.

\section{Data Uses}

Contaminant concentrations are evaluated and used to generate plume maps, trend plots, and crosssections. Contaminant concentrations are reported in RCRA quarterly and annual reports.

\subsubsection{Contaminant Sources, Driving Forces, and Migration Pathways}

\section{Data Needs and Approach}

Lateral and Vertical Contaminant Distribution. This information is supplied from the decision inputs described above for determining the lateral and vertical contaminant distributions (Section 3.3.2).

Contaminant Concentrations. This information is supplied from the decision input described above for determining the contaminant concentrations (Section 3.3.3).

Isotopic Signatures. The isotopic signature work is planned in the scope of work funded by the Hanford Site Groundwater Remediation Project's Science and Technology Project and not the scope of this groundwater assessment. However, this assessment will use information provided by the Science and Technology Project to the fullest extent possible.

A proposal has been submitted to Science and Technology Project to use isotopic signatures of various waste streams in the vicinity of WMA T and isotopic measurements of groundwater from WMA T monitoring wells as tools to distinguish the source or sources of groundwater contamination at WMA T. The special isotopic work is a joint project between Lawrence Berkeley National Laboratory and PNNL. The isotopic systems proposed include

- Ruthenium-101, -102, and -104.

- ${ }^{87} \mathrm{Sr} /{ }^{86} \mathrm{Sr}$.

- $\delta^{15} \mathrm{~N}$ and $\delta^{18} \mathrm{O}$ in nitrate.

- Uranium isotopes.

- Stable chromium isotopes.

All of these isotopic systems, except stable chromium, have been used previously at the Hanford Site. Although the chromium isotopic system may show little difference in the isotopic compositions of chromium from different Hanford Site sources, this proposition will be tested. It is speculative at the moment, but the chromium isotopes may reflect the fate of hexavalent chromium groundwater contamination.

New Monitoring Wells. Evaluation of information gathered during this assessment concerning source(s) of contamination, may lead to a conclusion that one or more new upgradient and/or 
downgradient wells are needed. Any new proposed wells will be submitted to the DQO process for prioritizing drilling and construction of new wells.

\section{Data Uses}

Results from these special isotopic studies may help determine the source or sources for the groundwater contamination at WMA T. Examples of the uses of the isotopic systems are given below. It is these types of information that may be applicable to the groundwater assessment at WMA T.

A ruthenium fission isotope investigation in the WMA B-BX-BY area found that the technetium-99: ruthenium-101 ratio was higher than expected from the fission yield and that there were two geographically distinguishable technetium-99:ruthenium-101 populations suggesting possible separate technetium-99 sources in the area (Dresel et al. 2002). The ruthenium isotopic ratios also suggest that there are two sources for fission products in the area: material processed at B Plant and material processed at Plutonium-Uranium Reduction (PUREX) Plant. Strontium isotopic ratios have been found to vary in Hanford Site groundwater due to a combination of exchange with sediments and quantity of infiltration. Areas with very high ${ }^{87} \mathrm{Sr} /{ }^{86} \mathrm{Sr}$ are believed to reflect disposal of large volumes of process water (Maher et al. 2003). The stable nitrogen and oxygen isotopes in nitrate have been used at the Hanford Site to help distinguish high-level tank waste from low-level process waste and nitric acid (Singleton et al. 2005). Uranium isotopic ratios have been used at the Hanford Site to provide tight constraints on the source of uranium groundwater contamination in the WMA B-BX-BY area (Christenson et al. 2004).

\subsection{Define the Boundaries of the Study}

This section defines the boundaries for groundwater quality assessment monitoring at WMA T. Spatial and temporal boundaries are described as well as well as boundaries on the monitoring network and the analytes to be monitored. This step in the DQO process defines the set of circumstances covered by the questions being addressed.

\subsubsection{Spatial Boundaries}

The spatial boundaries for groundwater quality assessment monitoring at WMA T are boundaries defining the WMA, the area upgradient of the WMA between the WMA and upgradient monitoring wells, and the boundaries of downgradient contaminant plumes emanating from the WMA. The uppermost aquifer within this geographical area is the area of most concern. The uppermost aquifer extends down to the Ringold Formation lower mud unit. If the vertical extent of contamination extends down to the lower mud unit (or to 36.6 meters below the water table if the lower mud unit is not present) in the planned new wells, drilling will continue through the lower mud to the top of basalt. If contamination is found below the lower mud unit (or below 36.6 meters below the water table), the lower spatial boundary will be the top of basalt. The vadose zone within the above described area is also of concern because contaminants in the vadose zone are a source for groundwater contamination. 


\subsubsection{Temporal Boundaries}

The first assessment report (Hodges 1998) found that the tank waste constituent technetium-99 had impacted groundwater. This implies that associated RCRA constituents chromium and nitrate have impacted groundwater in proportion to their concentrations relative to technetium-99 in tank waste. Under 40 CFR 265.93 (d)(7)(i), groundwater quality assessment monitoring must continue until final closure of WMA T. The expected closure date for all single-shell tanks is 2024.

\subsubsection{The Monitoring Network}

The current groundwater monitoring network at WMA T is based on the existing understanding of subsurface conditions. The initial groundwater monitoring network was designed based on a combination of professional judgment and modeling (Caggiano and Goodwin 1991; MEMO, Wilson et al. 1992). This provided an initial basis for the spacing and locations of wells. Subsequent wells were added to the network based on the same combination of judgment and modeling (Hodges and Chou 2001).

All four of the original WAC 173-160 compliant wells at WMA T (299-W10-15, 299-W10-16, 299-W11-27, and 299-W11-28) are dry as a result of the declining water table. In 2001, the last of the original wells, 299-11-28, could no longer be sampled. Since publication of the previous assessment plan (Hodges and Chou 2001), four additional wells in the WMA assessment monitoring network have gone dry (299-W10-12, 299-W11-23, 299-W11-24, and 299-W11-28).

The current groundwater monitoring network at WMA T consists of 14 wells (Figure 2.23). As-built diagrams for the current WMA T assessment network wells are presented in Appendix C. Five of these wells are older wells constructed before WAC 173-160 was implemented. Well 299-W10-1 has been used as an upgradient well since flow directions shifted from a northward direction toward the east. It is an older well, with a 24-m perforated interval. A new upgradient well (299-W10-28) was drilled in 2001.

One older well, 299-W10-8, is currently used to fill a gap on the north side of WMA T between two newer WAC-compliant wells. Two older wells, 299-W10-4 and 299-W11-12, are south of WMA T. These wells were used as upgradient wells before groundwater flow direction changed from northward to eastward. These wells still are used to monitor regional contaminant plumes impinging on the WMA. Finally, one older non-WAC compliant well, 299-W11-7, is located about 350 meters east of the southern part of the WMA and is used as a distant, downgradient well. Data obtained from other distant, downgradient wells monitored for CERCLA and AEA will be used by the WMA T assessment as appropriate.

One existing WAC-compliant well, well 299-W10-22 located north of the WMA, was used as a downgradient, distant well until the flow direction change in 1997. The well is now situated more lateral than downgradient to the WMA with respect to groundwater flow direction. However, it will be included in the monitoring network for WMA T during the next phase of assessment. Data from the next assessment phase will be used to determine whether well 299-W10-22 will remain in the network.

Five new downgradient wells were drilled at WMA T and added to the monitoring network since the previous assessment plan was written (299-W11-39 through 299-W11-42 and 299-W11-46). With the exception of well 299-W11-46, the drilling and construction details for these wells are found in borehole 
completion reports (Horton and Hodges 2001; Horton 2002). Well 299-W11-46 has just recently been completed and a borehole completion report will be made after all data become available. (Well 299-W11-46 was drilled to replace well 299-W11-25B which was damaged during construction.)

On the basis of observations at WMA T, Hodges (1998) and Hartman et al. (2000) postulated very narrow contaminant plumes and the need for a maximum spacing between wells of about 35 meters. The current well spacing on the downgradient side (east side) of WMA T ranges from 30 to 36 meters.

Two new wells are planned for fiscal year 2006. ${ }^{3}$ The locations for the wells are shown on Figure 2.23. The well labeled T-2 on the figure is located approximately 70 meters east of well 299-W11-46. This location is the estimated leading edge of the technetium-99 plume encountered in wells 299-W11-39 and 299-W11-46. Well T-2 will be drilled to the top of the Ringold Formation lower mud unit and sampled at pre-determined depth intervals during drilling. If contamination is encountered down to the lower mud, the well will be deepened to the top of basalt.

The second new well, well T-3 on Figure 2.23, will be drilled adjacent to well 299-W11-41. This is the location of the most recent, rapid increase in technetium-99 along the east side of WMA T. This well will also be drilled to the top of the Ringold Formation lower mud unit with the option to continue to top of basalt if deep contamination is encountered. Both new wells will be drilled such that they can be screened at depth in the aquifer and/or constructed as extraction wells for a pump-and-treat system if deemed necessary.

Additional new wells may be planned for calendar year 2006. However, the number and location of those wells will depend on the findings from the calendar year 2005 wells.

Some wells in the monitoring network may become unusable in the future because of the declining water table and/or changing direction of groundwater flow. If this happens, the effect on the monitoring network will be evaluated to determine whether it is necessary to either deepen the existing wells, where feasible, or to drill new wells. The need for additional new RCRA monitoring wells beyond those discussed above will be evaluated at least on an annual basis.

\subsubsection{Constituents to be Monitored}

The constituents to be monitored at WMA T include (1) RCRA-regulated, dangerous-waste constituents of concern, (2) non-RCRA non-dangerous-waste constituents of interest, and (3) supporting groundwater quality constituents. The constituents of concern are those constituents monitored for RCRA and discussed in Section 3.3.4.1 below. The constituents of interest are those constituents monitored under CERCLA and AEA to support tank farm retrieval and remediation and are discussed in Section 3.3.4.2. The supporting groundwater quality constituents are discussed in Section 3.3.4.3. All constituents to be monitored are listed in Table 3.3.

\footnotetext{
${ }^{3}$ Both planned wells were under construction at the time this document was prepared.
} 
Table 3.3. Constituents of Concern, Constituents of Interest, and Supporting Groundwater Quality Constituents to be Monitored at Waste Management Area T

\begin{tabular}{|c|c|}
\hline \multicolumn{2}{|c|}{ Constituents of Concern } \\
\hline Chromium & Nitrate \\
\hline \multicolumn{2}{|c|}{ Constituents of Interest } \\
\hline Fluoride & Technetium-99 \\
\hline Iodine-129 & Tritium \\
\hline Gross alpha & Gross beta \\
\hline \multicolumn{2}{|l|}{ Gamma scan } \\
\hline \multicolumn{2}{|c|}{ Supporting Groundwater Quality Constituents } \\
\hline Major metals & Major anions \\
\hline $\mathrm{pH}$ & Alkalinity \\
\hline Specific conductance & Turbidity \\
\hline Temperature & Dissolved oxygen \\
\hline Oxidation-reduction $\mathrm{p}$ & \\
\hline
\end{tabular}

\subsubsection{Constituents of Concern}

Chromium and nitrate are included as constituents of concern for RCRA monitoring at WMA T. The constituents of concern are those dangerous waste constituents regulated by RCRA that exist in the waste stored in WMA T and that are found in groundwater beneath WMA T. The specific constituents that have been documented in groundwater include chromium, nitrate, and carbon tetrachloride. Carbon tetrachloride is monitored under CERCLA and is not included as a WMA T groundwater assessment constituent of concern.

\subsubsection{Constituents of Interest}

The constituents of interest are non-RCRA regulated, non-dangerous waste constituents. The constituents of interest are compiled from known contaminants in groundwater beneath WMA T that are not covered in Section 3.3.4.1 and certain screening parameters for potential radionuclide contaminants.

The constituents of interest that are identified in the groundwater beneath WMA T are technetium-99, tritium, and fluoride. Iodine-129 is also included for one well (well 299-W11-41) because the well is near the western edge of the regional iodine-129 plume.

The screening parameters gross alpha, gross beta, and gamma scan are also included in the constituents of interest. These analyses are used to indicate the possible presence of common radionuclide contaminants in the vadose zone and/or groundwater including strontium-90, cesium-137, and various isotopes of uranium and plutonium. If a screening parameter indicates an increase in alpha, beta, or gamma activity that cannot be explained by an increase in a specific radionuclide that is already included as a constituent of interest, then additional radionuclide-specific analyses will be initiated. The screening parameters are less expensive than most radionuclide-specific analyses and their use greatly decreases the cost of monitoring. 


\subsubsection{Supporting Groundwater Quality Constituents}

Table 3.3 gives the supporting groundwater quality constituents. The supporting groundwater quality constituents are used to evaluate the chemical and physical quality of the sample. Basic hydrochemical information is obtained from the supporting groundwater quality constituents to allow quality control checks (e.g., cation/anion charge balance, specific conductance versus the sum of major constituents). Changes in $\mathrm{pH}$ and alkalinity also would be expected if tank waste or reaction products reached groundwater. Also, mixing of raw water (Columbia River water) with ambient groundwater may be discernable because the specific conductance and total dissolved solids are much lower for river water than for ambient groundwater. Some groundwater quality constituents can also help evaluate the size of liquid leaks and leak sources.

\subsubsection{Practical Constraints}

Although not strictly boundaries, practical constraints place limits on planned activities that get accomplished. The most obvious practical constraint is cost. Every effort is made to ensure the collection of the right types of data to support the decisions while keeping the cost of this assessment at a minimum. However, unforeseen changes in budgets may preclude some of the scope proposed for this groundwater assessment.

\subsection{Decision Rules}

Decision rules address the major or key questions and issues previously discussed. In accordance with the DQO process, "if-then" statements are formulated that lead to actions based on the data or information. However, not all issues or questions identified are amenable to this approach. Table 3.4 summarizes the decision rules and the following sections provide more detail.

\subsubsection{Groundwater Flow Rate and Direction}

The groundwater flow rate and flow direction are fundamental inputs to evaluating the lateral (and to some extent the vertical) distribution of contamination. The flow rate and flow direction are also valuable input to determine contamination sources. Therefore, the flow rate and flow direction where contaminants are encountered in the groundwater need to be known. However, a decision rule regarding flow rate and flow direction is not feasible because estimations of groundwater flow rate and flow direction are dependent on estimations of hydraulic conductivity and effective porosity, the accuracy of water-level measurements, and heterogeneities in the hydrogeologic system. The best possible recourse may be to continue collecting hydrologic data as they become available to refine existing estimates of groundwater conditions.

\subsubsection{Extent of Contamination}

The extent of groundwater contamination is required by 40 CFR 265.93(d)(4)(i). In addition, the extent of contamination is helpful to determine the source of contamination. Thus, it is important to 
know the spatial and vertical distribution of contaminants in the unconfined aquifer at WMA T. A decision rule regarding the lateral extent of contamination could be the following:

\section{If a given contaminant plume is enclosed laterally and downgradient by WMA T network wells or additional operable unit wells with concentrations of one-half or less of the drinking water standard for the given contaminant, then the lateral extent of the given contaminant plume is well understood.}

Table 3.4. Summary of Decision Rules

\begin{tabular}{|c|c|}
\hline Decision Statement ${ }^{(\mathrm{a})}$ & Decision Rule \\
\hline \multirow[t]{3}{*}{$\begin{array}{l}\text { What is the rate and extent of migration of dangerous waste } \\
\text { or dangerous waste constituents in the groundwater? }\end{array}$} & $\begin{array}{l}\text { A decision rule for flow rate is not appropriate because flow rate } \\
\text { and direction are dependent on estimates of hydrologic properties } \\
\text { from a heterogeneous and anisotropic system. }\end{array}$ \\
\hline & $\begin{array}{l}\text { If a given contaminant plume is enclosed laterally and downgra- } \\
\text { dient by WMA T network wells or additional operable unit wells } \\
\text { with concentrations of one-half or less of the drinking water } \\
\text { standard for the given contaminant, then the lateral extent of the } \\
\text { given contaminant plume is well understood. }\end{array}$ \\
\hline & $\begin{array}{l}\text { If sampling within a single well shows that, at some depth, the } \\
\text { concentration for a given contaminant is at the local background } \\
\text { level, and that concentrations above that depth passed through a } \\
\text { maximum value, then the vertical extent of contamination for the } \\
\text { given contaminant in the area is well known. }\end{array}$ \\
\hline \multirow[t]{3}{*}{$\begin{array}{l}\text { What are the concentrations of dangerous waste constituents } \\
\text { in the groundwater originating from the regulated unit? }\end{array}$} & $\begin{array}{l}\text { If contaminant concentrations are stable or on an established } \\
\text { trend line, then no frequency change will be made to the } \\
\text { sampling schedule. }\end{array}$ \\
\hline & $\begin{array}{l}\text { If a screening constituent shows an increase that can not be } \\
\text { accounted for by other monitored constituents, then additional } \\
\text { groundwater evaluation will be done. }\end{array}$ \\
\hline & $\begin{array}{l}\text { If results of the additional evaluation indicate that additional } \\
\text { constituents of concern or constituents of interest have adversely } \\
\text { impacted groundwater quality and are attributed to WMA T, then } \\
\text { that (those) constituent(s) will be added to the list of constituents } \\
\text { of concern or to the list of constituents of interest as appropriate. }\end{array}$ \\
\hline $\begin{array}{l}\text { What is the location or source of groundwater contamination } \\
\text { at WMA T? }\end{array}$ & $\begin{array}{l}\text { If more data are needed in a specific area to distinguish among } \\
\text { two or more potential sources of contamination, then the } \\
\text { location for appropriately placed new wells will be submitted for } \\
\text { consideration in the next update of the well drilling DQO. }\end{array}$ \\
\hline $\begin{array}{l}\text { What are the driving forces that account for the temporal } \\
\text { and spatial occurrences of contaminants in the groundwater } \\
\text { at WMA T? }\end{array}$ & $\begin{array}{l}\text { A decision rule for this decision statement is not appropriate } \\
\text { because determination of migration pathways results from a } \\
\text { synthesis of historical data, data gathered during this assessment, } \\
\text { and data gathered as part of other Hanford Site projects. }\end{array}$ \\
\hline $\begin{array}{l}\text { What are the pathways that allowed contamination to } \\
\text { traverse the vadose zone and enter groundwater at WMA T? }\end{array}$ & $\begin{array}{l}\text { A decision rule for this decision statement is not appropriate } \\
\text { because determination of driving mechanisms results from a } \\
\text { synthesis of historical data, data gathered during this assessment, } \\
\text { and data gathered as part of other Hanford Site projects. }\end{array}$ \\
\hline \multicolumn{2}{|l|}{$\begin{array}{l}\text { (a) From Section } 3.2 . \\
\text { (b) } \mathrm{DQO}=\text { Data quality objective. } \\
\text { (c) } \mathrm{WMA}=\text { Waste management area. }\end{array}$} \\
\hline
\end{tabular}


For cases where the lateral extent of a given contaminant plume is not known, additional wells may be necessary to define the extent of the plume. The installation of new wells is prioritized by the DQO process at the Hanford Site. Therefore, the addition of new wells to the WMA T monitoring network will be decided based on all of the Hanford Site's needs.

An additional decision rule regarding the vertical extent of contamination could be as follows:

If sampling within a single well shows that, at some depth, the concentration for a given contaminant is at the local background level, and that concentrations above that depth passed through a maximum value, then the vertical extent of contamination for the given contaminant in the area is well known.

For cases where the concentration for the given contaminant remains high at the total depth of the well, the vertical extent of contamination in the area is not well known. If the well is in the process of being drilled, the decision can be made by DOE, Ecology, and EPA to extend the depth of the well until contaminant concentrations approach local background. If the subject well is not a new well, decisions can be made to prioritize a new, deeper well at that location.

\subsubsection{Sampling and Analysis Considerations}

\subsubsection{Sampling Frequency}

A quarterly sampling frequency is required by 40 CFR 265.93(d)(7)(i) and by reference WAC 173-303-400(3) for RCRA-regulated constituents at WMA T. There are no requirements for sampling frequency associated with non-dangerous waste constituents at a WMA under groundwater quality assessment. The sampling frequency for each constituent sampled under this groundwater quality assessment plan is given in the Sampling and Analysis Plan (Appendix A).

A decision rule covering sampling frequency is as follows:

If contaminant concentrations are stable or on an established trend line, then no frequency change will be made to the sampling schedule.

All groundwater data are reviewed quarterly and the sampling schedule is reviewed annually. The sampling schedule will be changed if it is thought necessary by the project scientist.

\subsubsection{Analyzed Constituents}

The constituents of concern were defined in Section 3.4.4.1 as those dangerous waste constituents regulated by RCRA, and that exist in the wastes stored in WMA T, and that are found in groundwater beneath WMA T; specifically chromium and nitrate. The definition of constituents of concern allows for the list of those constituents to be changed (if additional dangerous wastes are found in the groundwater in the future). Decision rules addressing a change in the list of constituents of concern are as follows:

If a screening constituent shows an increase that can not be accounted for by other monitored constituents, then additional groundwater evaluation will be done. 
This additional evaluation may include more frequent sampling, or the analysis of specific constituents previously covered by a screening constituent (e.g., strontium-90 as indicated by gross beta), or analysis of other heretofore unconsidered constituent.

If results of the additional evaluation indicate that additional constituents of concern or constituents of interest have adversely impacted groundwater quality and are attributed to WMA T, then that (those) constituent(s) will be added to the list of constituents of concern or to the list of constituents of interest as appropriate.

\subsubsection{Contaminant Source(s), Migration Pathways, and Driving Mechanisms}

Determinations of contaminant source(s), migration pathways, and driving mechanisms results from syntheses of historical data, data gathered during this assessment, and data gathered as part of other programs such as the River Protection Project (RPP) Tank Farm Vadose Zone Project and the 200-ZP-1 Operable Unit. One likely outcome from these determinations is that more information is needed from a specific area to differentiate between two or more contaminant sources. The major access way for gathering additional information is through additional boreholes or wells. A decision rule addressing this is as follows:

If more data are needed in a specific area to distinguish among two or more potential sources of contamination, then the location for appropriately placed new wells will be submitted consideration in the next update of the well drilling DQO.

The well drilling DQO process will prioritize the needed wells with wells required by other Hanford Site projects.

\subsection{Optimize the Sampling Design}

The groundwater quality assessment program for WMA T outlined in this DQO section is judged to be the current most resource-effective data collection design for generating data that are expected to satisfy the DQOs. The resulting data collection design is given in the Sampling and Analysis Plan in Appendix A. However, priority and on-going activities frequently change at the Hanford Site and these changes could lead to further design optimization. Also, additional groundwater quality assessment information may lead to further design optimization. This assessment plan will be reviewed annually to determine whether the activities for the groundwater assessment remain the most resource-effective data generating activities.

An additional cost savings is realized by coordination of sampling activities among RCRA, CERCLA, and AEA monitoring. The sampling schedules for the three monitoring programs are integrated to minimize well trips and duplicate analyses.

Finally, a high resolution resistivity survey was begun at WMA T in 2005 by CH2M HILL Hanford Group, Inc. The method is being tested to see whether subsurface zones of high conductivity can be mapped. If the method proves successful, it can provide information useful for citing new wells. High resolution resistivity data will be used, if available, when citing new wells at WMA T. 


\subsection{References}

40 CFR 265. U.S. Environmental Protection Agency. "Interim Status Standards for Owners and Operators of Hazardous Waste Treatment, Storage, and Disposal Facilities.” Code of Federal Regulations.

Agnew SF, RA Corbin, TB Duran, KA Jurgensen, TP Ortiz, and BL Young. 1997. Waste Status and Transaction Record Summary (WSTRS Rev. 4). LA-UR-97-311, Los Alamos National Laboratory, New Mexico.

Atomic Energy Act, as amended, Ch. 1073, 68 Stat. 919,42 USA 2011 et seq.

Alexander DJ, SD Evelo, VG Johnson, and MD Sweeney. 1995. Groundwater Impact Assessment Report for the 216-T-4-2 Ditch. WHC-EP-0815, Westinghouse Hanford Company, Richland, Washington.

Anderson JD. 1990. A History of the 200 Area Tank Farms. WHC-MR-0132, Westinghouse Hanford Company, Richland, Washington.

ARH. 1973. 241-T-106 Tank Leak Investigation. ARH-2874, Atlantic Richfield Hanford Company, Richland, Washington.

Byrnes ME and BA Williams. 2003. Data Quality Objectives Summary Report for Establishing a RCRA/CERCLA/AEA Integrated 200 West and 200 East Area Groundwater Monitoring Network. Fluor Hanford, Inc., Richland, Washington.

Caggiano JA and CJ Chou. 1993. Interim-Status Groundwater Quality Assessment Plan for the Single Shell Tank Waste Management Areas T and TX-TY. WHC-SD-EN-AP-132, Westinghouse Hanford Company, Richland, Washington.

Caggiano JA and SM Goodwin. 1991. Interim-Status Groundwater Monitoring Plan for the SingleShell Tanks. WHC-SD-EN-AP-012, Rev. 1, Westinghouse Hanford Company, Richland, Washington.

Cantrell KJ, RJ Serne, and GV Last. 2002. Hanford Contaminant Distribution Coefficient Database and Users Guide. PNNL-13895, Pacific Northwest National Laboratory, Richland, Washington.

Chamness MA and JK Merz. 1993. Hanford Wells. PNL-8800, Pacific Northwest Laboratory, Richland, Washington.

Christensen JN, PE Dresel, ME Conrad, K Maher, and DJ Depaolo. 2004. "Identifying the Sources of Subsurface Contamination at the Hanford Site in Washington Using High-Precision Uranium Isotopic Measurements." Environmental Science Technology 38:3330-3337.

CERCLA - Comprehensive Environmental Response, Compensation, and Liability Act. 1980. Public Law 96-150, as amended, 94 Stat. 2767, 42 USC 9601 et seq. 
Corbin RA, BC Simpson, MJ Anderson, WF Danielson III, JG Field, TE Jones, and CT Kincaid. 2005. Hanford Soil Inventory Model, Rev. 1. Prepared by CH2M HILL Hanford Group, Inc. for the U.S. Department of Energy, Richland, Washington.

Delaney CD, KA Lindsey, and SP Reidel. 1991. Geology and Hydrology of the Hanford Site: A Standardized Text for Use in Westinghouse Hanford Company Documents and Reports. WHC-SC-ERTI-003, Westinghouse Hanford Company, Richland, Washington.

Domenico PA and GA Robbins. 1985. "A New Method of Contaminant Plume Analysis." Groundwater 23(4):476-485.

DOE. 1991. T-Plant Source Aggregate Area Management Study Report. DOE/RL-91-61, U.S. Department of Energy, Richland Operations, Richland, Washington.

DOE. 2000a. Addendum to the T Tank Farm Report. GJO-99-101-TARA, GJO-HAN-27, U.S. Department of Energy, Albuquerque Operations Office, Grand Junction Office, Grand Junction, Colorado. Available online at http://www.doegjpo.com/programs/hanf/HTFVZ.html

DOE. 2000b. Hanford Dangerous Waste Part A Permit Application. DOE/RL-88-21, U.S. Department of Energy, Richland Operations, Richland, Washington.

Dresel PE, JC Evans, and OT Farmer III. 2002. Investigation of Isotopic Signatures for Sources of Groundwater Contamination at the Hanford Site. PNNL-13763, Pacific Northwest National Laboratory, Richland, Washington.

Ecology - Washington State Department of Ecology, U.S. Environmental Protection Agency, and U.S. Department of Energy. 1998. Hanford Federal Facility Agreement and Consent Order. Document No. 89-10, Rev. 5 (The Tri-Party Agreement), Olympia, Washington.

EPA. 1986. RCRA Ground Water Monitoring Technical Enforcement Guidance Document (TEGD). National Waste Well Association, Dublin, Ohio.

EPA. 2000 as revised. Guidance for the Data Quality Objectives Process. EPA/600/R-96/055 (QA/G-4). U.S. Environmental Protection Agency, Washington, D.C.

Fecht KR, GV Last, and KR Price. 1977. Evaluation of Scintillation Probe Profiles from 200 Area Crib Monitoring Wells. Volume III. ARH-ST-156, Atlantic Richfield Hanford Company, Richland, Washington.

Fecht KR, BN Bjornstad, DG Horton, GV Last, SP Reidel, and KA Lindsey. 1999. Clastic Injection Dikes of the Pasco Basin and Vicinity. BHI-01103, Bechtel Hanford, Inc., Richland, Washington.

Field JG and TE Jones. 2005. Tank Farm Vadose Zone Contamination Volume Estimates. RPP-23405, Rev. 1, prepared by CH2M HILL Hanford Group, Inc. for the U.S. Department of Energy, Richland, Washington. 
Freeman-Pollard JR, JA Caggiano, SJ Trent, and EBASCO/Hart Crowser. 1994. Engineering Evaluation of the GAO/RCED-89-157, Tank 241-T-106 Vadose Zone Investigation. BHI-0061, Bechtel Hanford Company, Richland, Washington.

Gee GW and AL Ward. 2001. Vadose Zone Transport Field Study: Status Report. PNNL-13679, Pacific Northwest National Laboratory, Richland, Washington.

Gee GW and AL Ward. 2002. "Vadose Zone Transport Field Studies." In MJ Hartman, LF Morasch, and WD Webber, (eds.), Hanford Site Groundwater Monitoring for Fiscal Year 2001, PNNL-13788, Pacific Northwest National Laboratory, Richland, Washington.

Hanlon BM. 2004. Waste Tank Summary Report for Month Ending September 30, 2004. HNF-EP-0182, Rev. 198, CH2M HILL Hanford Group, Inc., Richland, Washington.

Hartman MJ and PE Dresel (eds.). 1997. Hanford Site Groundwater Monitoring for Fiscal Year 1996. PNNL-11470, Pacific Northwest National Laboratory, Richland, Washington.

Hartman MJ, LF Morasch, and WD Webber (eds.). 2000. Hanford Groundwater Monitoring for Fiscal Year 1999. PNNL-13116, Pacific Northwest National Laboratory, Richland, Washington.

Hartman MJ, LF Morasch, and WD Webber (eds.). 2001. Hanford Groundwater Monitoring for Fiscal Year 2000. PNNL-13404, Pacific Northwest National Laboratory, Richland, Washington.

Hartman MJ, LF Morasch, and WD Webber (eds.). 2002. Hanford Groundwater Monitoring for Fiscal Year 2001. PNNL-13788, Pacific Northwest National Laboratory, Richland, Washington.

Hartman MJ, LF Morasch, and WD Webber (eds.). 2003. Hanford Groundwater Monitoring for Fiscal Year 2002. PNNL-14187, Pacific Northwest National Laboratory, Richland, Washington.

Hartman MJ, LF Morasch, and WD Webber (eds.). 2004. Hanford Groundwater Monitoring for Fiscal Year 2003. PNNL-14548, Pacific Northwest National Laboratory, Richland, Washington.

Hartman MJ, LF Morasch, and WD Webber (eds.). 2005. Hanford Site Groundwater Monitoring for Fiscal Year 2004. PNNL-15070, Pacific Northwest National Laboratory, Richland, Washington.

Hodges FN. 1998. Results of Phase I Groundwater Quality Assessment for Single-Shell Tank Waste Management Areas T and TX-TY at the Hanford Site. PNNL-11809, Pacific Northwest National Laboratory, Richland, Washington.

Hodges FN and CJ Chou. 2001. RCRA Assessment Plan for Single-Shell Tank Waste Management Area $T$ at the Hanford Site. PNNL-12057, Pacific Northwest National Laboratory, Richland, Washington.

Horton DG. 2002. Borehole Data Package for Calendar Year 2001 RCRA Well Installation at SingleShell Tank Waste Management Area T. PNNL-13830, Pacific Northwest National Laboratory, Richland, Washington. 
Horton DG and FN Hodges. 2001. Borehole Data Package for Calendar Year 2000-2001 RCRA Wells at Single-Shell Tank Waste Management Area T. PNNL-13590, Pacific Northwest National Laboratory, Richland, Washington.

Horton DG, FN Hodges, VG Johnson, and CJ Chou. 2002. RCRA Groundwater Quality Assessment Report for Single-Shell Tank Waste Management Area T (January 1998 through December 2001). PNNL-13929, Pacific Northwest National Laboratory, Richland, Washington.

Jensen EJ, SP Airhart, MA Chamness, TJ Gilmore, DR Newcomer, and KR Oster. 1989. 40 CFR 265 Interim-Status Ground-Water Monitoring Plan for the Single-Shell Tanks. WHC-SD-EN-AP-012, Rev. 0, Westinghouse Hanford Company, Richland, Washington.

Johnson VG and CJ Chou. 1998. Results of Phase I Groundwater Quality Assessment for Single-Shell Tank Waste Management Areas S-SX the Hanford Site. PNNL-11810, Pacific Northwest National Laboratory, Richland, Washington.

Jones TE, R Khaleel, DA Myers, JW Shade, and MI Wood. 1998. A Summary and Evaluation of Hanford Site Tank Farm Subsurface Contamination. HNF-2603, Rev. 0, Lockheed Martin Hanford, Richland, Washington.

Jones TE, BC Simpson, MI Wood, and RA Corbin. 2000. Preliminary Inventory Estimates for SingleShell Tank Leaks in T, TX, and TY Tank Farms. RPP-7218, Rev. 0, CH2M HILL Hanford Group, Inc., Richland, Washington.

Kipp KL and RD Mudd. 1974. Selected Water Table Contour Maps and Well Hydrographs for the Hanford Reservation, 1944 - 1973. BNWL-260, Pacific Northwest Laboratories, Richland, Washington.

Lindsey KA. 1996. The Miocene to Pliocene Ringold Formation and Associated Deposits of the Ancestral Columbia River System, South-Central Washington and North-Central Oregon. Open File Report 96-8, Washington State Department of Natural Resources, Olympia, Washington.

Lindsey KA, SP Reidel, KR Fecht, JL Slate, AG Law, and AM Tallman. 1994. "Geohydrologic Setting of the Hanford Site, South-Central Washington." In DA Swanson and RA Haugerud, Geologic Field Trips in the Pacific Northwest, 1994 Annual Meeting, Geological Society of America, v. 1, p. 1C-1 - 16.

Lindsey KA, MP Connelly, and BN Bjornstad. 1992. Geologic Setting of the 200 West Area: An Update. WHC-SD-EN-TI-008, Westinghouse Hanford Company, Richland, Washington.

Lindsey KA and KD Reynolds. 1998. "Geology and Stratigraphy of the Tank Farms." In TE Jones, R Khaleel, DA Myers, JW Shade, and MI Wood. 1998. A Summary and Evaluation of Hanford Site Tank Farm Subsurface Contamination. HNF-2603, Rev. 0, Lockheed Martin Hanford, Richland, Washington.

Maher K, KJ DePaolo, ME Conrad, and RJ Serne. 2003. "Vadose Zone Infiltration Rate at Hanford, Washington, Inferred from Sr Isotope Measurements.” Water Resources Research 39:1204. 
Narbutovskih SM, DF Iwatate, MD Sweeney, AL Ramirez, W Daily, RM Morey, and L Christensen. 1996. Feasibility of CPT-Deployed Vertical Electrode Array in Single-Shell Tank Farms. WHC-SDEN-TA-004, Rev. 0, Westinghouse Hanford Company, Richland, Washington.

Price WH and KR Fecht. 1976. Geology of the 241-T Tank Farm. ARH-LD-135, Atlantic Richfield Hanford Company, Richland, Washington.

RCW 70.105. "Hazardous Waste Management.” Revised Code of Washington, Olympia, Washington.

Reidel SP and KR Fecht. 1994. Geologic Map of Richland 1:100,000 Quadrangle, Washington. Washington Division of Geology and Earth Resources Open -File Report 94-8, 21, 1 plate.

Reidel SP, VG Johnson, and FA Spane. 2002. Natural Gas Storage in Basalt Aquifers of the Columbia Basin, Pacific Northwest USA: A Guide to Site Characterization. PNNL-13962, Pacific Northwest National Laboratory, Richland, Washington.

Reidel SP, DG Horton, Y Chien, DB Barnett, and K Singleton. 2005. Geology, Hydrogeology, Geochemistry, and Mineralogy Data Package. RPP-23748, CH2M HILL Hanford Group, Inc., Richland, Washington.

Resource Conversation and Recovery Act, as amended, Public Law 94-580, 90 Stat. 2795, 42 USC 6901 et seq.

Routson RC, WH Price, DJ Brown, and KR Fecht. 1979. High-Level Waste Leakage from the 241-T-106 Tank at Hanford. RHO-ST-14, Rockwell Hanford Operations, Richland, Washington.

Serne RJ, BN Bjornstad, DG Horton, DC Lanigan, HT Schaef, CW Lindenmeier, MJ Lindberg, RE Clayton, VL LeGore, KN Geiszler, SR Baum, MM Valenta, IV Kutnyakov, TS Vickerman, RD Orr, and CF Brown. 2004. Characterization of Vadose Zone Sediments Below the T Tank Farm: Boreholes C4104, C4105, 299-W10-196, and RCRA Borehole 299-W11-39. PNNL-14849, Pacific Northwest National Laboratory, Richland, Washington.

Simpson BC, RA Corbin, and SF Agnew. 2001. Hanford Soil Inventory Model. BHI-01496, Rev. 0, Bechtel Hanford, Inc., Richland, Washington.

Singleton MJ, KN Woods, ME Conrad, DJ DePaolo, and PE Dresel. 2005. "Tracking Sources of Unsaturated Zone and Groundwater Nitrate Contamination Using Nitrogen and Oxygen Stable Isotopes at the Hanford Site, WA." Submitted to Environmental Science Technology.

Spane FA, PD Thorne, and DR Newcomer. 2001. Results of Detailed Hydrologic Characterization Tests - Fiscal Year 1999. PNNL-13378, Pacific Northwest National Laboratory, Richland, Washington.

Spane FA, PD Thorne, and DR Newcomer. 2002. Results of Detailed Hydrologic Characterization Tests - Fiscal Year 2001. PNNL-14186, Pacific Northwest National Laboratory, Richland, Washington.

Spane FA, DR Newcomer, and PD Thorne. 2003. Results of Detailed Hydrologic Characterization Tests - Fiscal Year 2002. PNNL-14186, Pacific Northwest National Laboratory, Richland, Washington. 
Tallman AM, KR Fecht, MC Marratt, and GV Last. 1979. Geology of the Separation Areas, Hanford Site, South-Central Washington. RHO-ST-23, Rockwell Hanford Operations, Richland, Washington.

WAC 173-160. "Minimum Standards for Construction and Maintenance of Wells." Washington Administrative Code, Olympia, Washington.

WAC-173-303-400. "Interim Status Facility Standards." Washington Administrative Code, Olympia, Washington.

Ward AL, CJ Murray, GW Gee, Y Xie, and ZF Zhang. 2004. "Impact of Clastic Dikes on Vadose Zone Flow." In MJ Hartman, LF Morasch, and WD Webber (eds.), Hanford Site Groundwater Monitoring for Fiscal Year 2003. PNNL-145489, Pacific Northwest National Laboratory, Richland, Washington.

Williams JC. 2000. Historical Vadose Zone Contamination from T, TX, and TY Tank Farm Operations. RPP-5957, Rev. 0., CH2M HILL Hanford Group, Richland, Washington.

Williams BA, BN Bjornstad, R Schalla, and WD Webber. 2002. Revised Hydrogeology for the Suprabasalt Aquifer System, 200-West Area and Vicinity, Hanford Site, Washington. PNNL-13858, Pacific Northwest National Laboratory, Richland, Washington.

Wood MI, R Schalla, BN Bjornstad, and FN Hodges. 2001. Subsurface Conditions Description of the T and TX-TY Waste Management Areas. RPP-7123, Rev. 0, CH2M HILL Hanford Group, Inc., Richland, Washington.

Wilson CR, CM Einberger, RL Jackson, and RB Mercer. 1992. "Design of Ground-Water Monitoring Network Using the Monitoring Efficiency Model (MEMO).” Groundwater 30(6):965-970. 


\section{Appendix A}

Sampling and Analysis Plan 


\section{Appendix A}

\section{Sampling and Analysis Plan}

This appendix consists of a field sampling plan (FSP) and a quality assurance project plan (QAPP). The FSP specifies the data collection design and the QAPP includes the procedures and project management controls intended to ensure the data collected and associated measurement errors are appropriate to meet the quantitative and qualitative data quality objectives (DQO). Together these two plans form the Sampling and Analysis Plan. The Sampling and Analysis Plan is used as the principal controlling document for conducting the work identified in Section 3.

\section{A.1 Field Sampling Plan}

This section contains the data collection design and activities for the continued groundwater quality assessment of Waste Management Area (WMA) T. A description of each task is provided as follows. Additional discussion and background information associated with the tasks are provided in the main body of the plan.

\section{A.1.1 Task Description}

The tasks described are a subpart of the Groundwater Performance Assessment Project (groundwater project) managed for the U.S. Department of Energy (DOE) by Pacific Northwest National Laboratory (PNNL). Project management and organizational interfaces and procedures are described in Section A.2.

\section{A.1.1.1 Well Testing and Special Sampling}

This task combines those activities that require removal of the sample pumps for free access to the well. Cost savings are achieved by combining the activities and minimizing disruption of the ongoing monitoring program. This task includes the following specific tests:

- Gyroscope surveys

- Special sampling

Gyroscopic Surveys. Past surveys have shown that monitoring wells are not necessarily vertical and straight. Knowing the exact configuration of a well is particularly necessary when multi-well aquifer testing is done. For this reason, gyroscopic surveys will be done in wells to be used for multi-well aquifer tests.

Special Sampling. Previous reports have shown that there are vertical concentration gradients for some constituents of concern and constituents of interest at WMA T (Hodges 1998; Horton et al. 2002; Serne et al. 2004). Several special sampling activities are planned at WMA T to better understand the vertical distribution of contaminants and are described below. 


\section{Specific Conductance Profiles}

Specific conductance profiles will be measured in wells 299-W11-39, 299-W11-40, 299-W11-41, 299-W11-42, 299-W10-4, and 299-W10-28. The first five of these wells are chosen because they are downgradient and monitor contaminated groundwater. The latter two wells are chosen for comparison purposes because they are not downgradient. The conductivity measurements will be taken with a calibrated meter fastened to an electrical tape. Measurements will be taken at 0.3 -meter intervals throughout the screened interval. Measurements will be repeated until two consecutive results are within $10 \%$.

\section{Discrete Depth Sampling}

Based on the results of the specific conductance profiles, passive multi-level sampling of groundwater using a dialysis cell equilibration method may be done in wells 299-W11-39, 299-W11-41, 299-W11-42, 299-W10-4, and 299-W10-28. The first three of these wells are chosen because they are downgradient and currently show increases in contaminant concentrations. The latter two wells are chosen for comparison because they are not downgradient but sample highly contaminated groundwater. The sampler consists of a support rod, 30-milliliter sample cells, and baffles separating the cells. The baffles rest against a well screen and prevent cross contamination from vertical in-well flow. The cells will be filled with water and placed in the well screen for a period of time sufficient to allow replacement of the water in the cells by formation water flowing into the well screen (nominally one to two weeks).

The multi-level pore water sampling device will be deployed in and retrieved from the wells using the pump setting rig used to remove and replace the dedicated sample pump from the well. The sampling device will be suspended in the well by a non-stretching cable and secured at the surface to a metal rod extended across the well head. Because the well cap may not fit on the well with the sampling device in place, the well head will be wrapped in plastic and taped tight while sampling is in progress.

At a minimum, depth discrete groundwater samples will be collected every meter throughout the screened intervals and analyzed for chromium, technetium-99, and nitrate. Analyses will be done at the PNNL's 325 Laboratory.

\section{A.1.1.2 Determine Groundwater Flow Direction}

Water Level Measurements. The depth to water will be measured quarterly in all wells at the time of sampling. These measurements are an indicator of conditions in the well at the time of sampling. However, because these measurements are generally taken over a time period of a few days, they are subject to differential barometric effects due to diurnal and storm-related changes in atmospheric pressure. Therefore, depth-to-water measurements taken at the time of sampling and used to construct water table maps will be corrected for changes in atmospheric pressure (Spane 1999).

Additionally, depth to water is measured annually in March to construct the annual Hanford Site water-table map. At WMA T, these March measurements are generally taken in all wells within a few hours time. Thus, the March measurements are not as susceptible to barometric effects as are the quarterly measurements. 


\section{A.1.1.3 Well Drilling and Testing}

Determining the vertical and lateral extent of groundwater contamination is required for this groundwater quality assessment (Section 3.3.2). For this purpose, two new wells were identified for WMA T in the DQO for prioritization of new groundwater monitoring wells (Byrnes and Williams 2003). One of those wells (299-W11-25B which was later replaced by 299-W11-46 after being damaged) was installed in calendar year 2005. The other new well (well T-2 on Figure 2.23) is scheduled for later in calendar year 2005. The second new well will be a mid-field well located about 70 meters downgradient of existing well 299-W11-25B to test the lateral and vertical extent of contamination coming from the area of well 299-W11-25B. ${ }^{1}$

The location of well T-2 was determined by using the best available hydrologic information (flow rate and flow direction) and the breakthrough of technetium-99 at wells 299-W11-27, 299-W11-23, and 299-W11-39. Using this information, well T-2 was located just outside of where the leading edge of the technetium-99 plume is expected.

As a result of groundwater analyses obtained during drilling of well 299-W11-25B, the DOE, U.S. Environmental Protection Agency (EPA), and Washington State Department of Ecology (Ecology) agreed to drill a third new well in calendar year 2005. The third well (well T-3 on Figure 2.23) tentatively is located adjacent to existing well 299-W11-41 near the southeast corner of WMA T. This is the location of the greatest rate of increase in technetium-99 downgradient of WMA T. However, the location of well T-3 may be changed pending the results of surface geophysical surveys being conducted by $\mathrm{CH} 2 \mathrm{M}$ HILL Hanford Group, Inc.

Both new wells will be drilled to the top of the Ringold Formation lower mud unit or to 36.6 meters below the water table if the lower mud unit is not present. If significant contamination exists at the top of the lower mud unit, drilling and sampling will continue to the top of basalt. Both new wells will be drilled so that casing can be downsized in the lower mud unit and can be constructed as extraction wells for a pump-and-treat system is deemed necessary.

Well construction will comply with the requirements for monitoring well design and construction as specified in 40 CFR 265.91(c) by reference of WAC 173-303-400(3). Specifications for well designs and procedures for performing the well installations are contained in Washington Administrative Code (WAC 173-160) and contractor/sub-contractor procedure manuals. A separate statement of work describing well specifications will be issued prior to well drilling. Only special conditions related to the WMA T groundwater assessment are described in this plan.

Data Collection Activities. Data collection activities associated with drilling the new wells include the following:

- Geologic description of sediments encountered during drilling.

- Collection of sediment samples returned to the surface during drilling.

- Collection and analysis of groundwater samples during drilling.

- Water level measurements.

\footnotetext{
${ }^{1}$ Well T-2 had been drilled and constructed at the time this document was published.
} 
- Geophysical logging.

- Well development parameters (drawdown during pumping and recovery).

- Aquifer testing.

- Deviation survey to determine borehole deviations caused by drilling.

\section{Geologic Description}

Continuous geologic description of drill cuttings is required. The purpose of the descriptions is to record the physical appearance and conditions of the vadose zone and saturated zone sediments to be used in conceptual models of subsurface hydrogeologic conditions. The geologic log will include descriptions of the following:

- Drilling conditions and changes in drilling conditions (e.g., drilling method, drill rate, addition of water, heaving sand).

- Depths of all collected samples.

- Lithologic descriptions of sediments.

- Water levels.

\section{Collection of Sediment Samples}

The purposes of the sediment samples are to (1) provide physical samples to aid geologist's description of lithologies, (2) provide a sample for future testing of physical or chemical properties as needed, and (3) provide an archive record of hydrogeologic conditions encountered during drilling.

Representative sediment samples will be collected at $1.5-\mathrm{m}$ intervals throughout the entire borehole. Additional samples will be collected at significant changes in lithology or at depths where unusual conditions or sediments are encountered. Samples will be collected in pint or quart, glass jars capable of sealing existing moisture in the sample for a reasonable time period. If representative samples can not be collected (for example, if large particles do not fit in the container), notes describing the condition of the sample will be put in the geologist's log. The samples will be archived in the Geotechnical Sample Library after collection. All sediment samples will be labeled with the borehole number, sample depth, and date of sample and documented on the geologist log.

In addition to the archived samples, small volume samples for chip trays will be collected. These samples will be made available to the project scientist to corroborate the field geologist descriptions and aid in the hydrogeologic interpretation for use in constructing maps and cross-sections for conceptual models.

No sediment samples will be collected from zones of subsurface contamination that would prohibit the uncontrolled transport and storage of the samples to the Geotechnical Sample Library in the 300 Area. The presence or absence of contamination will be determined by surveys using hand held instruments in the field conducted by radiological control technicians. Surveys will be on a schedule determined by the contractor responsible for well drilling. 


\section{Collection of Groundwater Samples}

This section briefly discusses groundwater sampling during drilling of two new wells in calendar year 2005. A more detailed description of sampling activities during drilling will be made in a sampling and analysis plan specific to the two wells. If sampling requirements change between the time this plan is written and the well-specific sampling and analysis plan is written, the well-specific plan takes precedence. Sampling for analytes not included in this Sample and Analysis Plan (e.g., volatile organics) will be coordinated through the Hanford Groundwater Remediation Project.

Two types of groundwater samples will be collected during drilling: grab samples and pumped samples. Samples will be collected as near to the water table as possible and at every $1.5-\mathrm{m}$ depth. The samples are to be representative, to the extent practicable, of the aquifer at the depth of the samples; therefore, the following collection method will be used. The grab samples will be air lifted if drilling is by air rotary or by dual-wall percussion; the grab samples will be bailed if drilling is by cable tool.

The geologist at the borehole will collect the samples in clean and new containers with screw top lids labeled with the borehole number, sample depth, and date and time of collection. Groundwater samples will be turned over to the groundwater project after collection. The groundwater project will decant the groundwater into the appropriate containers with preservatives if necessary. The specific conductance and $\mathrm{pH}$ will be measured at the time of decanting. Because the samples will be a mixture of groundwater and sediment slurry, all samples will be filtered. Sample bottles, preservatives, and associated sample paperwork will be supplied by the groundwater project.

Slurry sampling during drilling at well 299-W11-25B showed that soluble $\mathrm{Cr}^{6+}$ in the groundwater was reduced to insoluble $\mathrm{Cr}^{3+}$ during the time that particulates were allowed to settle and the groundwater was in contact with the drill cuttings. Therefore, during drilling of well 299-W14-11, special precautions were taken when sampling for $\mathrm{Cr}^{6+}$ (hexavalent chromium). An aliquot of the groundwater-slurry sample was pumped and filtered into a sample bottle preserved and labeled for hexavalent chromium analysis as soon as possible after the slurry sample was collected. Analyses of the samples for $\mathrm{Cr}^{6+}$ suggested that the chromium was reduced to the insoluble ion. For this reason, chromium will be analyzed only from pumped samples.

Pumped samples will be collected after purging the wells for at least one hour. Pumped samples will be collected from predetermined and pre-agreed upon depth by DOE, Ecology, and EPA. The specific depths for both pumped and grab samples will be specified in detailed sample and analysis plans.

All air lifted samples will be analyzed for anions (nitrate) and technetium-99 at the PNNL Applied Geology and Geochemistry Laboratory (325 Laboratory). Pumped samples will be analyzed for anions, chromium (total, filtered), and technetium-99 at the 325 Laboratory. In addition, pumped samples from well T-2 will be analyzed for tritium, gross alpha, gross beta, and gamma scan and pumped samples from well T-3 will be analyzed for tritium and iodine-129 at the groundwater project's contract laboratory.

Sample volumes are to be 50 milliliters for technetium-99 and nitrate in the air lifted samples. For pumped samples, volumes will be 1,000 milliliters for tritium, 50 milliliters for chromium, 50 milliliters for anions, 50 milliliters for technetium-99, 4,000 milliliters for gamma scan, 1,000 milliliters for gross 
alpha and gross beta, and 8,000 milliliters for iodine-129. The contract laboratory requires 20 milliliters for total activity scan. If insufficient water exists in an air lifted sample, the project scientist will prioritize the analytes.

The analysis of chromium, nitrate, and technetium-99 will require rapid turnaround from the laboratory so as to minimize standby time at the drill site.

Groundwater samples will be collected according to this sampling plan and documented procedures. Chain of custody is required for all samples transported to the laboratories. Instrumentation used during the collection of groundwater samples will be calibrated according to the manufacturer's procedures.

\section{Water-Level Measurements}

Water-level measurements are required at several times during well drilling, construction, and development. The purpose of the measurements is to aid understanding of the hydraulic properties of the aquifer through which the borehole is drilled. These properties are used to (1) decide well construction details such as screen slot size, screen length and depth, and pump depth; (2) interpret aquifer flow direction; and (3) interpret subsurface contaminant movement.

The depth to water should be measured (1) as soon as possible after encountering the water table; (2) periodically throughout the day after drilling activities have stopped for some time (at a minimum, once in the morning prior to drilling and once in the evening before leaving the borehole for the day); (3) during well development to monitor drawdown; and (4) after well development to monitor recovery.

Water-level measurements will be monitored during drilling and construction activities and well development.

\section{Borehole Deviation Surveys}

A borehole deviation survey will be conducted in the new boreholes to evaluate the amount of deviation from vertical. The amount of deviation is used to make corrections to depth-to-water measurements and determine water-table elevations.

The deviation surveys will be done with a downhole gyroscope in the wells prior to sample pump installation. The surveys will be scheduled by Fluor Hanford, Inc. and conducted by Duratek Technical Services according to Fluor Hanford, Inc. requirements.

\section{Geophysical Logging}

Spectral gamma geophysical logging is required in the new boreholes. The purposes of the logs are to determine the depth distribution of any gamma emitting contaminants around the borehole and to interpret subsurface lithology. The boreholes are to be logged throughout the entire drilled depth.

The results of geophysical logging will include a header sheet describing the test conditions (logging rate, logging dates, correction factors, calibration information, etc.) used during the logging and subse-

quent analysis and a log summary sheet describing the results of the geophysical logging. 
Geophysical logging will be done according to documented procedures by other DOE contractors (currently Stoller Corp.).

\section{Aquifer Testing}

Aquifer testing is to be done in each new borehole during drilling and after well construction. The test results will provide aquifer properties used to calculate groundwater flow velocity and help interpret the results of sampling and analysis. The tests to be done after well construction are independent of activities associated with drilling and construction of the new wells. Details of the aquifer tests will be described in a separate test plan.

Five slug tests will be done in each of new wells T-2 and T-3 during drilling. The depths will be specified in the well specifications provided to Fluor Hanford, Inc.

A more detailed suite of tests may be conducted in the new wells after well construction. (The detailed hydraulic tests are contingent on the budget level in fiscal year 2006.) The test suite may include slug tests, tracer-dilutions tests, tracer pumpback tests, constant-rate pumping tests, and vertical flow, in-well tracer tests. Vertical flow has been measured in existing wells screened at the water table and it is important to know whether such vertical flow extends deeper in the aquifer. Also, well T-3 will be adjacent to existing well 299-W11-41. Therefore, aquifer testing done in new well T-3 may use the existing well as an observation well.

In addition to aquifer tests scheduled for new wells, slug testing will be done in recently completed well 299-W11-46. Well 299-W11-46 is located adjacent to well 299-W11-39. The results of the slug tests in well 299-W11-46 will be used to evaluate whether additional and detailed aquifer tests will be useful in the well using the adjacent well as an observation well.

The types of data that will be obtained from aquifer testing and the data uses are as follows:
Slug Testing:
for evaluating well development conditions and to provide preliminary hydraulic property information (e.g., hydraulic conductivity) for design of subsequent hydrologic tests
Tracer-Dilution Test:
for determining the vertical distribution of hydraulic conductivity and/or groundwater flow velocity within the well screen section, and for identifying vertical flow within the well screen section.
Tracer-Pumpback Test: for tracer removal and characterizing effective porosity, an important hydraulic transport parameter
Pumping Test/Recovery: conducted in concert with tracer-pumpback test. Analysis of drawdown and recovery data provides quantitative hydraulic characterization property information, e.g., hydraulic conductivity, storativity, specific yield

\section{Criteria for Selection of Screened Interval}

There are three criteria for selecting the screened interval in the new WMA T well located downgradient of well 299-W11-25B. The basis for the criteria for selection of the screened interval is to sample that part of the aquifer with the highest levels of contaminants unless an adjacent well already 
samples the high contamination zone. If an adjacent well already samples the high contamination zone, the well will be screened below the screened interval of the existing well to allow for declines in the water table.

1. If there is a maximum in the concentration of Resource Conservation and Recovery Act (RCRA) regulated constituent chromium greater than 10 times site background (site background is $3.17 \mu \mathrm{g} / \mathrm{L}$ at the $95^{\text {th }}$ percentile) in the upper 36.6 meters of the aquifer at a depth greater than 10.7 meters, a 3 -meter screen will be centered on the concentration maximum. If a maximum concentration of chromium greater than 10 times site background exists in the upper 10.7 meters, then the top of a 10.7-meter screen will be placed at the water table.

2. If there is no maximum in chromium concentration greater than 10 times site background and if there is a maximum in the concentration of tank farm constituent technetium-99 greater than 10 times site background (site background is $0.988 \mathrm{pCi} / \mathrm{L}$ at the $95^{\text {th }}$ percentile) in the upper 36.6 meters of the aquifer at a depth greater than 10.7 meters, a 3-m length of screen will be centered on the concentration maximum. If a maximum concentration of technetium- 99 greater than 10 times site background exists in the upper 10.7 meters, then the top of a 10.7 -meter screen will be placed at the water table.

3. If there are no maxima in the concentrations of chromium or technetium-99 greater than 10 times site background, then a 10.7-meter screen will be placed at the water table.

There also are three criteria for the selection of the screened interval in the new WMA T well located adjacent to existing well 299-W11-41.

1. If there is a maximum in the concentration of RCRA-regulated constituent chromium greater than 10 times site background (site background is $3.17 \mu \mathrm{g} / \mathrm{L}$ at the $95^{\text {th }}$ percentile) below the 10.7 -meter depth in the aquifer (the bottom of the screen in adjacent well 299-W11-41), then a 3-meter length of screen will be centered on the concentration maximum.

2. If there is no maximum in chromium concentration greater than 10 time site background and if there is a maximum in the concentration of tank farm constituent technetium- 99 greater than 10 times site background (site background is $0.988 \mathrm{pCi} / \mathrm{L}$ at the $95^{\text {th }}$ percentile) at a depth below the 10.7 -meter depth in the aquifer, than a 3 -meter length of screen will be centered on the concentration maximum.

3. If there are no maxima in the concentrations of chromium or technetium-99 greater than 10 times site background below the 10.7-meter depth in the aquifer, then the top of a 3-meter screen will be placed 3 meters below the bottom of the screen in the adjacent well 299-W11-41.

\section{A.1.1.4 Quarterly Groundwater Sampling and Analysis}

Sampling in the WMA T well network identified for this assessment is an ongoing activity. A quarterly frequency is required by 40 CFR 265.93(d)(7)(i) by reference of WAC 173-303-400(3) for RCRA-regulated constituents. This frequency also is adopted for some constituents of interest and groundwater quality indicators. Other constituents of interest are sampled semi-annually or annually. These frequencies is judged to be adequate for assessing the rate and extent of contaminant migration in the groundwater, and contaminant concentrations for the WMA T based on the time response of previous 
contaminant occurrences in monitoring wells and a relatively slow groundwater flow rate (4 to 73 meters/year based on flow rates in Table 2.9 of the main report).

The selection of the constituents to be monitored was discussed in Section 3.4 of the main body of this assessment plan. The wells to be monitored and the monitoring schedule are shown in Table A.1.

\section{A.1.1.5 Special Isotopic Studies}

Special isotopic investigations are planned under the scope of the Science and Technology Project and in conjunction with Lawrence Berkeley National Laboratory to try and distinguish the source or sources for contamination downgradient of WMA T. The WMA T groundwater assessment will take full advantage of any results from the special isotope studies as is appropriate for the assessment. The isotopic systems to be investigated include

- Ruthenium-101, -102, and -104.

- ${ }^{87} \mathrm{Sr} /{ }^{86} \mathrm{Sr}$.

- $\delta^{15} \mathrm{~N}$ and $\delta^{18} \mathrm{O}$ in nitrate.

- Uranium isotopes.

- Stable chromium isotopes.

Several sample sets will be used for these studies. Nine depth-discrete samples of pumped groundwater from the new well 299-W11-25B will be available for isotopic analyses. Supplementing these samples are aliquots of the anion and inductively coupled plasma (ICP) metal samples collected in February 2005 from eight wells in the WMA T monitoring network (299-W10-1, 299-W 10-4, 299-W10-24, 299-W10-28, 299-W11-39, 299-W11-40, 299-W11-41, and 299-W11-42). In addition, 23 vadose zone pore water samples are available from two boreholes drilled through the T-106 leak in 2003. These sample sets can be augmented with additional groundwater samples from the May 2005 quarterly sampling if needed.

\section{A.1.1.7 Project Planning and Direction}

This task involves ensuring that tasks are on schedule, that resources and personnel will be available when they are needed, and developing workarounds when schedule conflicts occur. Preparation of the assessment plan (this document), preparation of further assessment work plans that may be necessary to implement individual tasks, and any subsequent revisions of the assessment plan are also included in this task. Attending meetings with stakeholders and the integration project team leads to ensure coordination with other related projects is part of this task.

\section{A.2 Quality Assurance Plan}

The groundwater quality assessment investigation at WMA $\mathrm{T}$ is an integral part of the RCRA groundwater-monitoring program of the consolidated groundwater project. The scope of the consolidated project includes groundwater monitoring and the hydrogeologic services necessary to install, design, and monitor groundwater quality and contaminant movement on the Hanford Site. The project is administered by PNNL for the Richland Operations Office of DOE, Environmental Restoration (ER) Branch. 
Table A.1. Sampling Schedule for Groundwater Monitoring at WMA T

\begin{tabular}{|c|c|c|c|c|c|c|c|c|c|c|c|c|c|c|c|c|c|c|c|}
\hline \multicolumn{5}{|c|}{ Constituents of Concern } & \multicolumn{15}{|c|}{ Constituents of Interest and Supporting Groundwater Quality Constituents } \\
\hline Well Name & Purpose $^{(\mathrm{a})}$ & 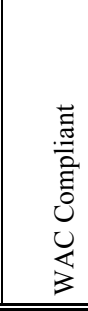 & 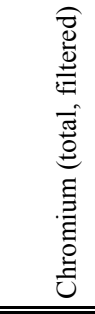 & 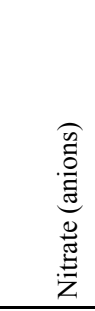 & 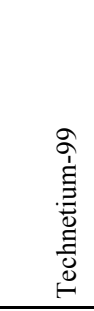 & 声 & 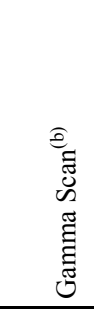 & 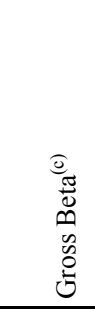 & 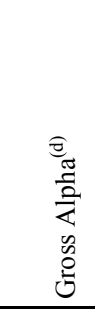 & 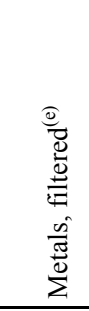 & 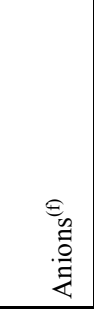 & 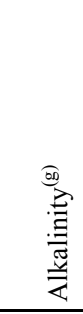 & 呰 & 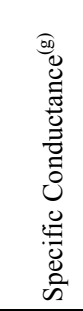 & 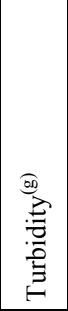 & 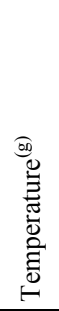 & 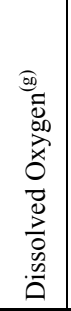 & 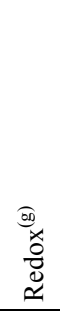 & 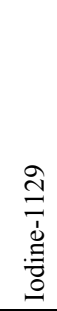 \\
\hline 299-W10-1 & Upgradient & $\mathrm{N}$ & $\mathrm{Q}$ & $\mathrm{Q}$ & $\mathrm{Q}$ & $\mathrm{Q}$ & $-(\mathrm{g})$ & A & A & $\mathrm{Q}$ & $\mathrm{Q}$ & QQ & $\mathrm{Q}$ & $\mathrm{Q}$ & $\mathrm{Q}$ & $\mathrm{Q}$ & $\mathrm{Q}$ & Q & \\
\hline 299-W10-4 & Assessment & $\mathrm{N}$ & Q & Q & Q & Q & A & A & $\mathrm{A}$ & Q & Q & Q & Q & Q & Q & $\mathrm{Q}$ & Q & $\mathrm{Q}$ & - \\
\hline 299-W10-8 & Downgradient & $\mathrm{N}$ & $\mathrm{Q}$ & $\mathrm{Q}$ & $\mathrm{Q}$ & $\mathrm{Q}$ & - & $\mathrm{A}$ & $\mathrm{A}$ & Q & $\mathrm{Q}$ & $\mathrm{Q}$ & $\mathrm{Q}$ & $\mathrm{Q}$ & $\mathrm{Q}$ & $\mathrm{Q}$ & $\mathrm{Q}$ & $\mathrm{Q}$ & - \\
\hline 299-W10-22 & Assessment & $\mathrm{Y}$ & $\mathrm{SA}$ & $\mathrm{SA}$ & $\mathrm{SA}$ & SA & - & - & - & SA & $\mathrm{SA}$ & SA & SA & SA & SA & SA & SA & SA & - \\
\hline 299-W10-23 & Assessment & $\mathrm{Y}$ & $\mathrm{Q}$ & $\mathrm{Q}$ & $\mathrm{Q}$ & Q & - & $\mathrm{A}$ & $\mathrm{A}$ & Q & $\mathrm{Q}$ & $\mathrm{Q}$ & $\mathrm{Q}$ & $\mathrm{Q}$ & $\mathrm{Q}$ & $\mathrm{Q}$ & $\mathrm{Q}$ & $\mathrm{Q}$ & - \\
\hline 299-W10-24 & Downgradient & $\mathrm{Y}$ & $\mathrm{Q}$ & $\mathrm{Q}$ & $\mathrm{Q}$ & $\mathrm{Q}$ & $\mathrm{SA}$ & SA & SA & $\mathrm{Q}$ & $\mathrm{Q}$ & $\mathrm{Q}$ & $\mathrm{Q}$ & $\mathrm{Q}$ & $\mathrm{Q}$ & $\mathrm{Q}$ & $\mathrm{Q}$ & $\mathrm{Q}$ & - \\
\hline 299-W10-28 & Upgradient & $\mathrm{Y}$ & Q & Q & Q & $\mathrm{Q}$ & - & $\mathrm{A}$ & $\mathrm{A}$ & Q & Q & Q & Q & Q & $\mathrm{Q}$ & $\mathrm{Q}$ & Q & Q & - \\
\hline 299-W11-7 & Far Field & $\mathrm{N}$ & SA & SA & SA & SA & - & - & - & SA & SA & SA & SA & SA & SA & SA & SA & SA & - \\
\hline 299-W11-12 & Downgradient & $\mathrm{N}$ & $\mathrm{Q}$ & Q & Q & Q & - & $\mathrm{A}$ & $\mathrm{A}$ & $\mathrm{Q}$ & Q & Q & Q & Q & $\mathrm{Q}$ & $\mathrm{Q}$ & Q & $\mathrm{Q}$ & - \\
\hline 299-W11-46 & Downgradient & $\mathrm{Y}$ & $\mathrm{Q}$ & $\mathrm{Q}$ & $\mathrm{Q}$ & $\mathrm{Q}$ & $\mathrm{SA}$ & SA & SA & $\mathrm{Q}$ & $\mathrm{Q}$ & $\mathrm{Q}$ & $\mathrm{Q}$ & $\mathrm{Q}$ & $\mathrm{Q}$ & $\mathrm{Q}$ & $\mathrm{Q}$ & $\mathrm{Q}$ & - \\
\hline 299-W11-39 & Downgradient & $\mathrm{Y}$ & Q & Q & Q & $\mathrm{Q}$ & SA & SA & SA & Q & Q & $\mathrm{Q}$ & $\mathrm{Q}$ & $\mathrm{Q}$ & $\mathrm{Q}$ & $\mathrm{Q}$ & $\mathrm{Q}$ & $\mathrm{Q}$ & - \\
\hline 299-W11-40 & Downgradient & Y & Q & Q & Q & Q & - & $\mathrm{A}$ & $\mathrm{A}$ & Q & Q & Q & $\mathrm{Q}$ & Q & $\mathrm{Q}$ & $\mathrm{Q}$ & Q & $\mathrm{Q}$ & - \\
\hline 299-W11-41 & Downgradient & $\mathrm{Y}$ & Q & $\mathrm{Q}$ & $\mathrm{Q}$ & Q & SA & SA & SA & Q & Q & $\mathrm{Q}$ & $\mathrm{Q}$ & $\mathrm{Q}$ & $\mathrm{Q}$ & $\mathrm{Q}$ & $\mathrm{Q}$ & $\mathrm{Q}$ & $\mathrm{A}$ \\
\hline 299-W11-42 & Downgradient & Y & Q & Q & Q & Q & SA & SA & SA & Q & Q & Q & Q & Q & $\mathrm{Q}$ & $\mathrm{Q}$ & Q & $\mathrm{Q}$ & - \\
\hline New Well T-2 & Far Field & $\mathrm{Y}$ & Q & $\mathrm{Q}$ & $\mathrm{Q}$ & $\mathrm{Q}$ & $\mathrm{A}$ & $\mathrm{A}$ & $\mathrm{A}$ & Q & Q & $\mathrm{Q}$ & Q & $\mathrm{Q}$ & $\mathrm{Q}$ & $\mathrm{Q}$ & $\mathrm{Q}$ & $\mathrm{Q}$ & - \\
\hline New Well T-3 & Downgradient & $\mathrm{Y}$ & $\mathrm{Q}$ & $\mathrm{Q}$ & $\mathrm{Q}$ & $\mathrm{Q}$ & SA & SA & SA & Q & $\mathrm{Q}$ & $\mathrm{Q}$ & $\mathrm{Q}$ & $\mathrm{Q}$ & $\mathrm{Q}$ & $\mathrm{Q}$ & $\mathrm{Q}$ & $\mathrm{Q}$ & - \\
\hline $\begin{array}{l}\text { (a) Assessme } \\
\\
\text { (b) Gar field } \\
\text { (c) Gross Bet } \\
\text { (d) Gross Alp } \\
\text { (e) Metals - } \\
\text { (f) Anions - } \\
\text { (g) Field Me } \\
\text { (h) Dash indi }\end{array}$ & $\begin{array}{l}\text { wells are not ne } \\
\text { ells are wells loca } \\
\text { an - Analytes inc } \\
\text { - Indicator paran } \\
\text { a - Indicator para } \\
\text { talytes include bu } \\
\text { nalytes include b } \\
\text { urement. } \\
\text { ates analysis is no }\end{array}$ & $\begin{array}{l}\text { cessaril } \\
\text { ated far } \\
\text { lude bu } \\
\text { neter fo } \\
\text { ameter } \mathrm{f} \\
\text { ut are no } \\
\text { ut are } n \\
\text { ot perfo }\end{array}$ & $\begin{array}{l}\text { irectly up } \\
\text { vngradie } \\
\text { e not lim } \\
\text { rontium- } \\
\text { iranium } \\
\text { mited to } \\
\text { imited to } \\
\text { ed for the }\end{array}$ & $\begin{array}{l}\text { downgr } \\
\text { o determ } \\
\text { d to coba } \\
\text { and othe } \\
\text { topes an } \\
\text { aminum, } \\
\text { trite, nitr } \\
\text { dicated }\end{array}$ & $\begin{array}{l}\text { ent. Son } \\
\text { lateral } \\
60 \text {, cesiu } \\
\text { eta emitt } \\
\text { ther alph } \\
\text { muth, ch } \\
\text {, chlorid }\end{array}$ & $\begin{array}{l}\text { assessme } \\
\text { ent of cor } \\
137 \text {, eurc } \\
\text { mitters. } \\
\text { mium, m } \\
\text { ulfate, a }\end{array}$ & $\begin{array}{l}\text { wells are } \\
\text { mination } \\
\text { um-152, }\end{array}$ & ed to hel & listinguis & plumes & pinging & the Wl & A T. & & & & & & \\
\hline
\end{tabular}


The consolidated groundwater project was established in 1996 when scope and personnel for the RCRA groundwater and related operational monitoring activities were transferred from Westinghouse Hanford Company to PNNL. The groundwater project quality assurance plan and current subcontractor procedures/manuals cover much of the work activities required for conducting the WMA T groundwater quality assessment.

Project description, project organization and designated responsibilities, and project management interfaces between DOE and subcontractor organizations are described in the groundwater project quality assurance plan.

\section{A.2.1 Groundwater Sampling and Analysis Protocol}

Samples will be collected for this assessment both during routine quarterly sampling and during drilling of new wells. The sampling and analysis methods and procedures and associated quality control for routine quarterly groundwater sampling and analysis are described in detail in Hartman 2000. Sampling during drilling is a non-routine type of sampling. The requirements for these latter samples are documented in sampling and analysis plans that specifically address each individual well and its requirements and are not covered in this QAPP.

\section{A.2.1.1 Water-Level Monitoring}

Field personnel measure depth to water before sampling or at other times as specified by the groundwater project (e.g., annual water-level measurements). The tapes used to make depth measurements are periodically calibrated. Field personnel obtain two consecutive measurements that agree within 6 millimeters and record them along with date, time, measuring tape number, and other pertinent information. Depth to water is subtracted from the elevation of a reference point (usually top of casing) to obtain water-level elevation. Water-level elevations are used to construct water-table maps.

Groundwater flow direction beneath WMA T is inferred from the water-table map(s) and plume maps. Rate of flow is estimated from hydraulic gradient, hydraulic conductivity and porosity or from rates of contaminant movement.

\section{A.2.1.2 Routine, Quarterly Sampling and Analysis Protocol}

Groundwater monitoring for WMA $\mathrm{T}$ is part of groundwater project and follows project quality assurance protocols. Groundwater monitoring for WMA T will follow the requirements of the most recent revision of the project quality assurance protocols; this monitoring plan need not be revised to cite future revisions of those protocols.

Project staff schedule sampling and initiate paperwork and oversee sample collection, shipping, and analysis. Quality requirements for any work subcontracted are specified in statements of work or contracts.

The statement of work for sampling activities specifies that those activities will be conducted in accordance with a quality assurance project plan that meets the requirements defined in Requirements for 
Quality Assurance Project Plans, EPA/240/B-01/003 (EPA QA/R-5) (EPA 2001, as revised). Additional requirements are specified in the statement of work.

Groundwater project staff conduct laboratory audits and field surveillances to assess the quality of subcontracted work and initiate corrective action if needed.

\section{Scheduling Groundwater Sampling}

The groundwater project schedules well sampling. Many Hanford Site wells are sampled for multiple objectives and requirements; e.g., RCRA, Comprehensive Environmental Response, Compensation, and Liability Act (CERCLA), and Atomic Energy Act (AEA). Scheduling activities help manage the overlap, eliminate redundant sampling, and meet the needs of each sampling objective. Scheduling activities include the following:

- Each fiscal year, project scientists provide well lists, constituent lists, and sampling frequency. Each month, project scientists review the sampling schedule for the following month. Changes are requested via change request forms and approved by the sampling and analysis task lead and monitoring project manager.

- Project staff track sampling and analysis through an electronic schedule database stored on a server at PNNL. Quality control samples also are managed through this database. A scheduling program generates unique sample numbers, and a special user interface generates sample authorization forms, field services reports, groundwater sample reports, chain-of-custody forms, and sample container labels.

- Sampling and analysis staff verify that well name, sample numbers, bottle sizes, preservatives, etc. are indicated properly on the paperwork, which is transmitted to the sample collector. Staff verify that the paperwork was generated correctly.

- At each month's end, project staff use the schedule database to determine if any wells were not sampled as scheduled. If the wells or sampling pumps require maintenance, sampling is rescheduled following repair. If a well can no longer be sampled it is cancelled, and the reason is recorded in the database.

\section{Chain of Custody}

The sample collector uses chain-of-custody forms to document the integrity of groundwater samples from the time of collection through data reporting. The forms are generated during scheduling and managed by the sample collector. Samplers enter required information on the forms, including the following:

- Sampler's name(s).

- Method of shipment and destination.

- Collection date and time.

- Sample identification numbers.

- Analysis methods.

- Preservation methods. 
When samples are transferred from one custodian to another (e.g., from sampler to shipper or shipper to analytical laboratory), the receiving custodian inspects the form and samples and notes any deficiencies. Each transfer of custody is documented by the printed names and signatures of the custodian relinquishing the samples and the custodian receiving the samples, and the time and date of transfer.

\section{Sample Collection}

All of the wells in the WMA T network are equipped with dedicated sampling pumps. Field personnel measure water levels in each well prior to sampling, then purge stagnant water from the well. Groundwater samples generally are collected after three casing volumes of water have been purged from the well or after field parameters ( $\mathrm{pH}$, temperature, specific conductance, and turbidity) have stabilized.

For routine groundwater samples, preservatives are added to the collection bottles, if necessary, before their use in the field. Samples for metals analyses are filtered in the field with 0.45 micrometer, in-line, disposable filters. After sampling, $\mathrm{pH}$, temperature and specific conductance are measured again. Sample bottles are sealed with evidence tape and placed in a cooler with ice for shipping.

\section{Analytical Protocols}

Instruments for field measurements (e.g., $\mathrm{pH}$, specific conductance, temperature, and turbidity) are calibrated using standard solutions prior to use and are operated according to manufacturer's instructions. Each instrument is assigned a unique number that is tracked on field documentation and calibrated and controlled.

Laboratory analytical methods are specified in contracts with the laboratories, and are standard methods from Test Methods for Evaluating Solid Wastes, Physical/Chemical Methods (EPA/SW-846; EPA 1986, as revised) or Methods for Chemical Analysis of Water and Wastes (EPA-600/4-79-020, EPA 1983, as revised).

\section{A.2.2 Borehole Drilling and Testing and Well Completion}

Fluor Hanford, Inc. manages borehole drilling and well installation under their safety and related job control procedures. Data needs and objectives from this assessment plan are transmitted by letter report to Fluor Hanford, Inc. to include in the detailed specifications for the drilling contracts.

Several types of samples will be taken during drilling as described in Section A.1. The types of samples include (1) geologic drill cuttings for archive, (2) chip tray samples, and (3) groundwater samples for chemical analysis.

\section{A.2.2.1 Geologic Drill Cutting Samples}

Drill cutting samples will be taken at 1.5-m depth intervals for archival purposes. Sampling activities will be administered in accordance with applicable procedures in subcontractor's manuals. The archived drill cuttings are archived in the Hanford Geotechnical Sample Library in the 300 Area. Chain of custody is not required for the archived samples. 
The well site geologist will describe the samples in the field and record the descriptions on borehole logs per approved Hanford Site contractor procedures. The field descriptions will be based on drill cuttings. Each sample collected will be recorded on a borehole log at the drill site. Detailed field lithologic descriptions of available material will include, if possible, color, texture, sorting, bulk mineralogy, roundness, relative calcium carbonate reactivity, consolidation, and cementation. All drilling and well construction data, sample depths, radiological and chemical survey points, will be documented on the borehole logs.

\section{A.2.2.2 Groundwater Sampling}

Slurries of groundwater and drill cuttings will be sampled during drilling as described in Section A.1. Sampling during drilling is a non-routine sampling event. The requirements of sampling during drilling are documented in separate sampling and analysis plans that are specific to each new well. Chain of custody is required for groundwater samples collected during drilling.

\section{A.2.2.3 Analysis of Groundwater Sampled Collected during Drilling}

Groundwater samples to be transferred to the groundwater project's contract laboratories will be analyzed according to approved laboratory stand operating procedures.

Groundwater samples to be transferred to the PNNL 325 Laboratory in the 300 Area will be analyzed according to the laboratory's established and approved procedures.

\section{A.2.2.4 Borehole Geophysics}

Borehole geophysical logging (spectral gamma ray) will be done in each new well. If the well is drilled using other than dual-wall casing, a neutron moisture log will also be done. The logging will be done by a subcontractor using the subcontractor's approved logging procedures. Optimal conditions for logging require that no more than one thickness of casing be present. This will require logging to be done in stages before each additional casing is telescoped into place.

\section{A.2.2.5 Well Completion}

The well will be completed as a standard RCRA monitoring well according to WAC 173-160 specifications. The length of the well screen and the screen depth will be based on analysis of samples collected during drilling. The procedure for selecting the well screen depths for the new calendar year 2005 wells at WMA T is in Section A.1.

\section{A.2.2.6 Gyroscope}

Gyroscope surveys will be conducted by Duratek Federal Services, Inc. using established and approved procedures.

\section{A.2.2.7 Hydrologic Testing}

The requirements and procedures for hydrologic testing will be documented in a separate sampling and testing plan. 


\section{A.2.3 Quality Assurance}

The groundwater project's quality assurance protocols meet EPA Requirements for Quality Assurance Project Plans, EPA/240/B-01/003 (EPA QA/R-5), (EPA 2001 as revised). A quality control protocol is included in the groundwater project quality documentation, and quality control sampling requirements for subcontracted work are discussed in the statement of work with the subcontractor.

The groundwater project's quality control program is designed to assess and enhance the reliability and validity of groundwater data. This is accomplished through evaluating the results of quality control samples, conducting audits, and validating groundwater data. This section describes the quality control program for the entire groundwater project, which includes WMA T. The quality control practices of the groundwater project are based on EPA guidance cited in the Tri-Party Agreement Action Plan, Section 6.5 (Ecology et al. 1989). Accuracy, precision, and detection are the primary parameters used to assess data quality (Mitchell et al. 1985). Data for these parameters are obtained from two categories of quality control samples: those that provide checks on field and laboratory activities (field quality control) and those that monitor laboratory performance (laboratory quality control). Table A.2 summarizes the types of samples in each category and the sample frequencies and characteristics evaluated.

Table A.2. Quality Control Samples

\begin{tabular}{|c|c|c|}
\hline Sample Type & Primary Characteristics Evaluated & Frequency \\
\hline \multicolumn{3}{|l|}{ Field Quality Control } \\
\hline Full Trip Blank & Contamination from containers or transportation & 1 per 20 well trips \\
\hline Field Transfer Blank & Airborne contamination from the sampling site & $\begin{array}{l}1 \text { each day volatile organic } \\
\text { compound samples are collected }\end{array}$ \\
\hline Equipment Blank & $\begin{array}{l}\text { Contamination from non-dedicated sampling } \\
\text { equipment }\end{array}$ & 1 per 10 well trips or as needed ${ }^{(a)}$ \\
\hline Duplicate Samples & Reproducibility & 1 per 20 well trips \\
\hline \multicolumn{3}{|l|}{ Laboratory Quality Control } \\
\hline Method Blank & Laboratory contamination & 1 per batch \\
\hline Lab Duplicates & Laboratory reproducibility & Method/contract specific ${ }^{(\mathrm{b})}$ \\
\hline Matrix Spike & Matrix effects and laboratory accuracy & Method/contract specific ${ }^{(\mathrm{b})}$ \\
\hline Matrix Spike Duplicate & Laboratory reproducibility and accuracy & Method/contract specific ${ }^{(\mathrm{b})}$ \\
\hline Surrogates & Recovery/yield & Method/contract specific ${ }^{(\mathrm{b})}$ \\
\hline Laboratory Control Sample & Accuracy & 1 per batch \\
\hline Double Blind Standards & Accuracy and precision & Varies by constituent $^{(\mathrm{c})}$ \\
\hline \multicolumn{3}{|c|}{$\begin{array}{l}\text { (a) When a new type of non-dedicated sampling equipment is used, an equipment blank should be collected every time } \\
\text { sampling occurs until it can be shown that less frequent collection of equipment blanks is adequate to monitor the } \\
\text { equipment's decontamination procedure. }\end{array}$} \\
\hline $\begin{array}{lllllll}1 & 1 & 1 & 1\end{array}$ & $\begin{array}{l}\text { method, duplicates, matrix spikes, and matrix spi } \\
\text { les. Surrogates are routinely included in every sam }\end{array}$ & $\begin{array}{l}\text { iplicates are typically analyzed at a } \\
\text { or most gas chromatographic }\end{array}$ \\
\hline (c) & $\begin{array}{l}\text { aining known concentrations of selected analytes a } \\
\text { semi-annual, or annual basis. }\end{array}$ & pically submitted in triplicate or \\
\hline
\end{tabular}




\section{A.2.3.1 Quality Control Criteria}

Quality control data are evaluated based on established acceptance criteria for each quality control sample type. For field and method blanks, the acceptance limit is generally two times the instrument detection limit (for metals), or method detection limit (for other chemical parameters). However, for common laboratory contaminants such as acetone, methylene chloride, 2-butanone, and phthalate esters, the limit is five times the method detection limit. Groundwater samples that are associated (i.e., collected on the same date and analyzed by the same method) with out-of-limit field blanks are flagged with a "Q" in the database to indicate a potential contamination problem.

Field duplicates must agree within $20 \%$, as measured by the relative percent difference (RPD), to be acceptable. Only those field duplicates with at least one result greater than five times the appropriate detection limit are evaluated. Unacceptable field duplicate results are also flagged with a "Q" in the database.

The acceptance criteria for laboratory duplicates, matrix spikes, matrix spike duplicates, surrogates, and laboratory control samples are generally derived from historical data at the laboratories in accordance with Test Methods for Evaluating Solid Wastes, Physical/Chemical Methods (EPA 1986 as revised). Typical acceptance limits are within $25 \%$ of the expected values, although the limits may vary considerably with the method and analyte. Current values for laboratory duplicates, matrix spikes, and laboratory control samples are $20 \%$ RPD, $60 \%$ to $140 \%$, and $70 \%$ to $130 \%$, respectively. These values are subject to change if the contract is modified or replaced.

Table A.3 lists the acceptable recovery limits for the double blind standards. These samples are prepared by spiking background well water (currently wells 699-19-88 and 699-49-100C) with known concentrations of constituents of interest. Spiking concentrations range from the detection limit to the upper limit of concentration determined in groundwater on the Hanford Site. Double blind standard results that are outside the acceptance limits are investigated, and appropriate actions are taken if necessary.

Holding time is the elapsed time period between sample collection and analysis. Exceeding recommended holding times could result in changes in constituent concentrations due to volatilization, decomposition, or other chemical alterations. Recommended holding times depend on the analytical method, as specified in Test Methods for Evaluating Solid Wastes, Physical/Chemical Methods (EPA 1986, as revised) or Methods for Chemical Analysis of Water and Wastes (EPA 1983, as revised). These holding times are specified in laboratory contracts. Data associated with exceeded holding times are flagged with an " $\mathrm{H}$ " in the Hanford Environmental Information System (HEIS) database. Flagged data generally are suitable for use in plume maps and trend plots, but may not be suitable for decision-making.

Additional quality control measures include laboratory audits and participation in nationally based performance evaluation studies. The contract laboratories participate in national studies such as the EPA-sanctioned water pollution and water supply performance evaluation studies. The groundwater project periodically audits the analytical laboratories to identify and solve quality problems, or to prevent such problems. Audit results are used to improve performance. Summaries of audit results and performance evaluation studies are presented in the annual groundwater monitoring report. 
Table A.3. Recovery Limits for Double Blind Standards

\begin{tabular}{||l|c|c|c||}
\hline \multicolumn{1}{|c|}{ Constituent } & Frequency & $\begin{array}{c}\text { Recovery Limits } \\
(\%)\end{array}$ & Precision Limits (RSD) (\%) \\
\hline \hline Specific conductance & Quarterly & $75-125$ & 25 \\
\hline Fluoride & Quarterly & $75-125$ & 25 \\
\hline Nitrate & Quarterly & $75-125$ & 25 \\
\hline Chromium & Annually & $80-120$ & 20 \\
\hline Gross alpha $^{(\text {a) }}$ & Quarterly & $70-130$ & 20 \\
\hline Gross beta $^{(\text {b) }}$ & Quarterly & $70-130$ & 20 \\
\hline Tritium & Annually & $70-130$ & 20 \\
\hline Cobalt-60 & Annually & $70-130$ & 20 \\
\hline Strontium-90 & Semiannually & $70-130$ & 20 \\
\hline Technetium-99 & Quarterly & $70-130$ & 20 \\
\hline Iodine-120 & Semiannually & $70-130$ & \\
\hline Uranium & Quarterly & $70-130$ & \\
\hline $\begin{array}{l}\text { (a) Gross alpha standards will be spiked with plutonium-239. } \\
\text { (b) Gross beta standards will be spiked with strontium-90. } \\
\text { RSD = Relative standard deviation. }\end{array}$ \\
\hline
\end{tabular}

\section{A.2.3.2 Groundwater Data Validation Process}

The groundwater project's data validation process provides requirements and guidance for validation of groundwater data that are routinely collected as part of the groundwater project. Validation is a systematic process of reviewing data against a set of criteria to determine whether the data are acceptable for their intended use. This process applies to groundwater data that have been verified (see Section A.2.4.1) and loaded into HEIS. The outcome of the activities described below is an electronic data set with suspect or erroneous data corrected or flagged. Groundwater project staff document the validation process quarterly. Documentation is stored in the project file.

Responsibilities for data validation are divided among project staff. Each monitored facility or geographic region is assigned to a project scientist, who is familiar with the hydrogeologic conditions of that site. The data validation process includes the following elements.

- Generation of data reports - Twice each month, data management staff provide tables of newly loaded data to project scientists for evaluation (biweekly reports). Also, after laboratory results from a reporting quarter have been loaded into HEIS, staff produce tables of water-level data and analytical data for wells sampled within that quarter (quarterly reports). The quarterly data reports include any data flags added during the quality control evaluation or as a result of prior data review.

- Project scientist evaluation - As soon as practical after receiving biweekly reports, project scientists review the data to identify changes in groundwater quality or potential data errors. Evaluation techniques include comparing key constituents to historical trends or spatial patterns. Other data checks may include comparison of general parameters to their specific counterparts (e.g., 
conductivity to ions) and calculation of charge balances. Project scientists request data reviews if appropriate (see Section A.2.4.2). If necessary, the laboratory may be asked to check calculations or reanalyze the sample, or the well may be resampled. After receiving quarterly reports, project scientists review sampling summary tables to determine whether network wells were sampled and analyzed as scheduled. If not, they work with other project staff to resolve the problem. Project scientists also review quarterly reports of analytical and water-level data using the same techniques as for biweekly reports. Unlike the biweekly reports, the quarterly reports usually include a full data set (i.e., all the data from the wells sampled during the previous quarter have been received and loaded into HEIS).

- Staff report results of quality control evaluations informally to project staff, DOE, and Ecology each quarter. Results for each fiscal year are described in the annual groundwater monitoring report.

\section{A.2.4 Data Management and Reporting}

This section describes how groundwater data are stored, retrieved, and interpreted.

\section{A.2.4.1 Loading and Verifying Data}

The contract laboratories report analytical results electronically and in hard copy. The electronic results are loaded into HEIS. Hard copy data reports and field records are maintained as part of the Hanford Facility operating record, unit specific file for the monitored facility. Project staff perform an array of computer checks on the electronic file for formatting, allowed values, data flagging (qualifiers), and completeness. Verification of the hard copy results includes checks for (1) completeness, (2) notes on condition of samples upon receipt by the laboratory, (3) notes on problems that arose during the analysis of the samples, and (4) correct reporting of results. If data are incomplete or deficient, staff work with the laboratory to get the problems corrected. Notes on condition of samples or problems during analysis may be used to support data reviews (see Section A.2.4.2).

Field data such as specific conductance, $\mathrm{pH}$, temperature, turbidity, and depth-to-water are recorded on field records. Data management staff enter these into HEIS manually through data-entry screens, verify each value against the hard copy, and initial each value on the hard copy.

\section{A.2.4.2 Data Review}

The groundwater project conducts special reviews of groundwater analytical data or field measurements when results are in question. Groundwater project staff document the process on a review form, and results are used to flag the data appropriately in HEIS. Various staff may initiate a review form: e.g., project scientists, data management staff, and quality control staff. The data review process includes the following steps:

- The initiator fills out required information on the review form, such as sample number, constituent, and reason for the request (e.g., "result is two orders of magnitude greater than historical results and disagrees with duplicate"). The initiator recommends an action, such as a data re-check, sample re-analysis, well re-sampling, or simply flagging the data as suspect in HEIS. 
- The data review coordinator determines that the review form does not duplicate a previously submitted review form, then assigns a unique review form number and records it on the form. A temporary flag is assigned to the data in HEIS indicating the data are undergoing review (" $F$ " flag).

- If laboratory action is required, the data review coordinator records the laboratory's response on the review form. Other documentation also may be relevant, such as chain-of-custody forms, field records, calibration logs, or chemist's sheets.

- A project scientist assigned to examine a review form determines and records the appropriate response and action on the review form including changes to be made to the data flags in HEIS. Actions may include updating HEIS with corrected data or result of re-analysis, flagging existing data (e.g., "R" for reject, "Y" for suspect, "G" for good), and/or adding comments. Data management staff updates the temporary "F" flag to the final flag in HEIS.

- The data review coordinator signs the review form to indicate its closure.

- If a review form is filed on data that are not "owned" by the groundwater project, the data review coordinator forwards a copy of the partially filled review form to the appropriate contact for their action. The review is then closed.

\section{A.2.4.3 Interpretation}

After data are validated and verified, the acceptable data are used to interpret groundwater conditions at the site. Interpretive techniques include the following.

\section{Hydrographs}

Hydrographs will be made using historical (and current) water level information. Hydrographs show water levels versus time for specified wells. Hydrographs are used to determine decreases, increases, seasonal, or manmade fluctuations in groundwater levels.

\section{Water-Table Maps}

Water-table maps will be made using both current and historic water-level measurements. The current water-table maps will be made with water-level measurements obtained as described above. The historic water-table maps will be made with data in the groundwater project's water-level database.

Care must be exercised in using water table maps (and hydrographs) for interpretation purposes because there are several potential problems with using historic water level data. In addition to unknown barometric effects, other potential sources of error in resulting water table maps and calculated watertable gradients include (1) the straightness of the wells; (2) for some time periods, a relatively flat water table coupled with measurement errors; (3) the communication between the aquifer and the screened or perforated part of the well; (4) changes in lithology; and (5) periodic and local influence from nearby liquid disposal facilities. 


\section{Trend Plots}

Trend plots will be made using current and historic groundwater compositions. Trend plots graph concentrations of constituents versus time to determine increases, decreases, and fluctuations; they may be used in tandem with hydrographs and/or water-table maps to determine if concentrations relate to changes in water level or in groundwater flow directions.

\section{Plume Maps}

Plume maps will be prepared for chromium and nitrate and for selected constituents of interest such as technetium-99. These maps will be made using results of current groundwater sampling and analysis. The maps will describe the current understanding of contaminant distribution. Changes in plume distribution over time aid in determining movement of plumes and direction of flow. Plume maps are prepared by the groundwater project quarterly and published annually. Plume maps generally reflect the geographic distribution of contamination in the uppermost part of the aquifer where most wells are screened.

\section{Contaminant Ratios}

Ratios of contaminant concentrations will be calculated and used to distinguish between different sources for the contamination is possible. Contaminant ratios are only useful where chemically different waste streams were disposed to two or more different potential source facilities.

\section{Three Point Analyses}

Corrected water-table elevations will be used to calculate groundwater flow direction using the threepoint analysis (three point problem) method. The method is commonly used by geologists to determine the strike and dip of a plane from the elevations of three points. For this application, the groundwater flow direction is equivalent to the dip of the water table determined by measured water-table elevations in three wells. Several triplets of wells will be used.

\section{Transport Modeling}

A simple transport models will be used to (1) predict the distribution of hypothetical contaminants released within the WMA and (2) help locate any future wells to be drilled in calendar year 2006.

The monitoring analysis package (Golder 1991) includes the Plume Generation Model (PLUME), the Monitoring Efficiency Model (MEMO), and the Contamination Probability Model (COPRO). This task will use the PLUME model in conjunction with professional judgment estimates to assess the extent of contamination at WMA T.

PLUME uses an analytical contaminant transport function to generate dilution contour plots of a contaminant plume emanating from a line source of specified length. The model has been used since 1992 to generate the plumes used by the MEMO model. PLUME is based on the two-dimensional analytical transport model presented in Domenico and Robbins (1985) and modified in Domenico (1987). 
This model assumes that solute is released along a continuous line source in a uniform aquifer, and predicts the concentrations that would be observed at points downstream of the source. The important user input parameters include the following:

- Advection time.

- Source history.

- Width of line source.

- Longitudinal and transverse dispersivities.

- Diffusion coefficient.

- First order decay constant.

- Average contaminant velocity.

Because some of these parameters are not well known, the model will be run to simulate a variety of conditions.

One of the primary uses of the model results is to aid professional judgment in locating any new monitoring wells planned for calendar year 2006. The model results will estimate potential migration distances downgradient from WMA T.

The model can also be run "backwards." That is, the contaminant configuration today can be used with estimated historical conditions as input to the model and the model can be run for different periods of time representing the time periods when groundwater flow was to the south, north, and east. These results may help verify potential source area for contamination.

\section{A.2.4.4 Reporting}

Regular annual progress reports are required for RCRA sites that are in assessment. As required by 40 CFR 265.94(b)(2) [by reference of WAC 173-303-400(3)], the results of the groundwater quality assessment program must be submitted to the regulator (Ecology) no later than March 1 following each calendar year. Also, as part of the groundwater project, it is anticipated that quarterly status reports will be submitted to DOE and Ecology. Borehole completion packages must also be prepared for each new monitoring well installed to document compliance with WAC 173-160.

\section{A.4 References}

40 CFR 265. U.S. Environmental Protection Agency. "Interim Status Standards for Owners and Operators of Hazardous Waste Treatment, Storage, and Disposal Facilities." Code of Federal Regulations.

Atomic Energy Act, as amended, Ch. 1073, 68 Stat. 919,42 USA 2011 et seq.

Byrnes ME and BA Williams. 2003. Data Quality Objectives Summary Report for Establishing a RCRA/CERCLA/AEA Integrated 200 West and 200 East Area Groundwater Monitoring Network. CP-15329, Rev. 0, Fluor Hanford, Inc., Richland, Washington. 
CERCLA - Comprehensive Environmental Response, Compensation, and Liability Act. 1980. Public Law 96-150, as amended, 94 Stat. 2767, 42 USC 9601 et seq.

DOE. 1997. Hanford Site Background: Part 3, Groundwater Background. DOE/RL-96-61, U.S. Department of Energy, Richland, Washington.

Domenico PA and GA Robbins. 1985. "A New Method of Contaminant Plume Analysis." Groundwater 23(4):6-485.

Domenico PA. 1987. "In Analytical Model for Multidimensional Transport of a Decaying Contaminant Species." Journal of Hydrology 91:49-58.

Ecology - Washington State Department of Ecology, U.S. Environmental Protection Agency, and U.S. Department of Energy. 1989. Hanford Federal Facility Agreement and Consent Order. Document No. 89-10, as amended, (The Tri-Party Agreement), Olympia, Washington.

EPA. 1983, as revised. Methods for Chemical Analysis of Water and Wastes. EPA-600/4-79-020, U.S. Environmental Protection Agency, Washington, D.C.

EPA. 1986, as revised. Test Methods for Evaluating Solid Waste: Physical/Chemical Methods, SW-846, Third Edition. Office of Solid Waste and Emergency Response, U.S. Environmental Protection Agency, Washington, D.C.

EPA. 1993, as revised. Methods for the Determination of Inorganic Substances in Environmental Samples. EPA-600/R-93-100, U.S. Environmental Protection Agency, Washington, D.C.

EPA. 2001, as revised. EPA Requirements for Quality Assurance Project Plans.

EPA/240/B-01/003/(QA/R-5). U.S. Environmental Protection Agency, Washington, D.C.

Golder. 1991. Monitoring Analysis Package (MAP) User's Manual - Version 1.0. 903-1268, prepared by Golder Associates, Inc. for Westinghouse Hanford Company, Richland, Washington.

Hartman MJ (ed.). 2000. Hanford Site Groundwater Monitoring: Setting, Sources and Methods. PNNL-13080, Pacific Northwest National Laboratory, Richland, Washington.

Hodges FN. 1998. Results of Phase I Groundwater Quality Assessment for Single-Shell Tank Waste Management Areas T and TX-TY at the Hanford Site. PNNL-11809, Pacific Northwest National Laboratory, Richland, Washington.

Horton DG, VG Johnson, FN Hodges, and CJ Chou. 2002. RCRA Groundwater Quality Assessment Report for Single-Shell Tank Waste Management Area T (January 1998 through December 2001). PNNL-13929, Pacific Northwest National Laboratory, Richland, Washington.

Mitchell WJ, RC Rhodes, and FF McElroy. 1985. "Determination of Measurement Data Quality and Establishment of Achievable Goals for Environmental Measurements." Quality Assurance for Environmental Measurements, ASTM STP 867. 
Resource Conversation and Recovery Act. 1976. Public Law 94-580, as amended, 90 Stat. 2795, 42 USC 6901 et seq.

Serne RJ, BN Bjornstad, DG Horton, DC Lanigan, HT Schaef, CW Lindenmeier, MJ Lindberg, RE Clayton, VL LeGore, KN Geiszler, SR Baum, MM Valenta, IV Kutnyakov, TS Vickerman, RD Orr, and CF Brown. 2004. Characterization of Vadose Zone Sediments Below the T Tank Farm: Boreholes C4104, C4105, 299-W10-196, and RCRA Borehole 299-W11-39. PNNL-14849, Pacific Northwest National Laboratory, Richland, Washington.

Spane FA, Jr. 1999. Effects of Barometric Fluctuations on Well Water-Level Measurements and Aquifer Test Data. PNNL-13078, Pacific Northwest National Laboratory, Richland, Washington.

WAC 173-160. "Minimum Standards for Construction and Maintenance of Wells." Washington Administrative Code, Olympia, Washington.

WAC-173-303-400. "Interim Status Facility Standards." Washington Administrative Code, Olympia, Washington. 


\section{Appendix B}

\section{Supporting Information}




\section{Appendix B}

\section{Supporting Information}

This section contains supporting geologic and groundwater monitoring information. This appendix includes the following information:

- Data about wells used to interpret the geology and hydrology.

- Geologic data used to interpret the geology and hydrology.

- As-built diagrams for wells in the WMA T monitoring network. 
Table B.1. Wells and Data Sources Used in This Report

\begin{tabular}{|c|c|c|c|c|c|c|c|c|}
\hline Well Name & Sample Method ${ }^{(a)}$ & Northing (m) & Easting (m) & $\begin{array}{c}\text { Surface } \\
\text { Elevation (m) }\end{array}$ & $\begin{array}{c}\text { Survey } \\
\text { Reference }\end{array}$ & $\begin{array}{l}\text { Total Depth } \\
\text { (m) }\end{array}$ & Drill Date & Data Sources \\
\hline 299-W10-1 ${ }^{\text {(b) }}$ & & 136734.6 & 566663.1 & 207.459 & NAVD88 & 93.0 & 1947 & Driller's Log, CaCO3, Gamma Log, Sieve \\
\hline 299-W10-2 & CT & 136798 & 566672 & 206.601 & NAVD88 & 70.1 & 1953 & Driller’s Log, CaCO3, Gamma Log, Sieve \\
\hline 299-W10-3 & CT & 136673.4 & 566731.9 & 205.763 & NAVD88 & 72.8 & 1951 & Driller’s Log, Gamma Log \\
\hline 299-W10-4 & CT & 136578.1 & 566734.6 & 205.524 & NAVD88 & 74.7 & 1952 & Driller's Log, Gamma Log, CaCO3, Sieve \\
\hline 299-W10-8 & CT & 136811.2 & 566848.8 & 208.382 & NAVD88 & 76.8 & 1973 & Driller's Log, CaCO3, Sieve \\
\hline 299-W10-9 & $\mathrm{CT}$ & 136798.8 & 566748.2 & 206.746 & NAVD88 & 68.6 & 1973 & Driller’s Log, Sieve \\
\hline 299-W10-10 & $\mathrm{CT}$ & 136805.9 & 566751.3 & 206.873 & NAVD88 & 76.2 & 1973 & Driller's Log, Sieve \\
\hline 299-W10-11 & СT & 136802.2 & 566755 & 206.845 & NAVD88 & 76.2 & 1974 & Driller's Log \\
\hline 299-W10-12 & DB 0-36 HT 36-76 & 136797.5 & 566755.6 & 206.768 & NAVD88 & 76.2 & 1974 & Driller's Log \\
\hline 299-W10-15 & DB 0-29 HT 29-68 & 136808 & 566770.4 & 207.039 & NAVD88 & 67.8 & 1989 & Geologist’s Log, Gamma Log \\
\hline 299-W10-16 & $\begin{array}{l}\text { DB } 0-13,17-36 \\
\text { HT } 13-12,36-67\end{array}$ & 136606.6 & 566780.9 & 206.162 & NAVD88 & 67.0 & 1989 & Geologist's Log, Gamma Log \\
\hline 299-W10-22 & DB 0-32, HT 32-91 & 136883.1 & 566832.6 & 208.954 & NAVD88 & 91.4 & 1994 & Geologist's Log, Gamma Log \\
\hline 299-W10-23 & Air Rotary & 136815.3 & 566823.7 & 207.4707 & NAVD88 & 82.9 & 1998 & Geologist's Log, Gamma Log \\
\hline 299-W10-24 & Air Rotary & 136798.8 & 566885.4 & 209.7253 & NAVD88 & 129.1 & 1998 & Geologist's Log, Gamma Log \\
\hline 299-W10-28 & DB 0-175 HT 175-280 & 136709.9 & 566701.6 & 206.826 & NAVD88 & 85.3 & 2001 & Geologist's Log, Gamma Log \\
\hline 299-W10-196 & CT - SS & 136724.8 & 566787.8 & 205.286 & NGVD29 & 53.9 & 1992 & Geologist's Log, Gamma Log, Moisture \\
\hline 299-W11-7 & HT & 136675.3 & 567260.9 & 217.108 & NAVD88 & 96.0 & 1951 & Driller's Log \\
\hline 299-W11-12 & HT & 136598.3 & 566928.6 & 208.201 & NAVD88 & 76.2 & 1953 & Driller's Log \\
\hline 299-W11-23 & $\begin{array}{l}\text { DB } 0-25 \\
\text { HT } 25-77\end{array}$ & 136801.1 & 566905 & 210.778 & NAVE88 & 76.8 & 1973 & Driller’s Log, Sieve \\
\hline 299-W11-24 & $\begin{array}{l}\text { HT 0-9 DB 12-36 } \\
\text { HT } 36-76\end{array}$ & 136744.5 & 566913 & 210.553 & NAVE88 & 76.2 & 1973 & Driller's Log \\
\hline 299-W11-25B & DWP & NA & NA & NA & NA & 124.8 & 2005 & Geologist's Log, Gamma Log \\
\hline 299-W11-26 & Core 27 to TD & 2220255 & 448095 & 211.4 & NA & 157.0 & 1976 & Driller’s Log \\
\hline
\end{tabular}


Table B.1. (contd)

\begin{tabular}{|c|c|c|c|c|c|c|c|c|}
\hline Well Name & Sample Method ${ }^{(a)}$ & Northing (m) & Easting (m) & $\begin{array}{c}\text { Surface } \\
\text { Elevation (m) }\end{array}$ & $\begin{array}{c}\text { Survey } \\
\text { Reference }\end{array}$ & $\begin{array}{c}\text { Total Depth } \\
\text { (m) }\end{array}$ & Drill Date & Data Sources \\
\hline 299-W11-30 & DB 0-35 HT 35-87 & 136858.9 & 567193.4 & 216.14 & NGVD29 & 86.8 & 1991 & Geologist's Log, Gamma Log \\
\hline |299-W11-39 & \begin{tabular}{|l|} 
SS 6 - 28 \\
HT 28 -86
\end{tabular} & 136779.9 & 566908.4 & 210.55 & NAVD88 & 86.0 & 2000 & Geologist's Log, Gamma Log \\
\hline 299-W11-42 & DB 0-64; HT 64-85 & 136745.7 & 566929.4 & 211.066 & NAVD88 & 85.3 & 2000 & Geologist's Log \\
\hline
\end{tabular}


Table B.2. Geologic Data for WMA $\mathrm{T}^{(\mathrm{a})}$

\begin{tabular}{|c|c|c|c|c|c|c|c|c|c|c|c|}
\hline Well Name & $\begin{array}{l}\text { Elevation at } \\
\text { Bottom }^{(\mathrm{b})}(\mathrm{m})\end{array}$ & $\begin{array}{c}\text { Water-Level } \\
\text { Elevation }(\mathrm{m})\end{array}$ & \begin{tabular}{|c|} 
Date of Water \\
Level
\end{tabular} & $\begin{array}{l}\text { Top of Hanford } \\
\text { Formation Sand } \\
\text { Sequence }\end{array}$ & \begin{tabular}{|c|} 
Top of Cold \\
Creek Fluvial \\
Sequence \\
\end{tabular} & $\begin{array}{c}\text { Top of Cold } \\
\text { Creek Caliche }\end{array}$ & \begin{tabular}{|c|} 
Top of Taylor \\
Flats
\end{tabular} & $\begin{array}{l}\text { Top of } \\
\text { Unit E }\end{array}$ & $\begin{array}{c}\text { Top of Lower } \\
\text { Mud }\end{array}$ & $\begin{array}{l}\text { Top of } \\
\text { Unit A }\end{array}$ & $\begin{array}{l}\text { Top of } \\
\text { Basalt }\end{array}$ \\
\hline 299-W10-1 & 113.7 & 137.117 & $5 / 02$ & 188 & 184 & 178 & 173 & 165 & & & \\
\hline 299-W10-2 & 135.9 & 141.298 & $6 / 95$ & 187 & 180 & 176 & 172 & 167 & & & \\
\hline 299-W10-3 & 133.0 & 141.88 & $7 / 93$ & 198 & 180 & 177 & 172 & 167 & & & \\
\hline 299-W10-4 & 130.5 & 137.023 & $5 / 02$ & 189 & 178 & 175 & 170 & 165 & & & \\
\hline 299-W10-8 & 130.7 & 136.829 & $6 / 02$ & 194 & 182 & 179 & 172 & 169 & & & \\
\hline 299-W10-9 & 137.2 & 139.873 & $6 / 96$ & 191 & 181 & 178 & 168 & 165 & & & \\
\hline 299-W10-10 & 129.7 & 136.957 & $6 / 02$ & 197 & 184 & 179 & 172 & 165 & & & \\
\hline 299-W10-11 & 129.8 & 137.685 & $6 / 00$ & 197 & 181 & 177 & 168 & 165 & & & \\
\hline 299-W10-12 & 129.7 & 137.679 & $6 / 00$ & 189 & 181 & 178 & 171 & 165 & & & \\
\hline 299-W10-15 & 138.7 & 138.401 & 9/99 & 188 & 184 & 178 & 175 & 165 & & & \\
\hline 299-W10-16 & 138.2 & 138.323 & $9 / 99$ & 188 & 180 & 177 & 173 & 166 & & & \\
\hline 299-W10-22 & 117.0 & 136.809 & 6/02 & 198 & 183 & 180 & 175 & 165 & & & \\
\hline 299-W10-23 & 123.7 & 136.877 & $6 / 02$ & 192 & 181 & 179 & 172 & 166 & & & \\
\hline 299-W10-24 & 127.1 & 136.8 & $6 / 02$ & 199 & 184 & 179 & 176 & 170 & 84 & & \\
\hline 299-W10-28 & 120.6 & 137.219 & 11/01 & 189 & 181 & 177 & 172 & 167 & & & \\
\hline 299-W10-196 & 150.9 & NA & NA & 193 & 180 & 177 & 173 & 168 & & & \\
\hline 299-W11-7 & 120.8 & 136.315 & $5 / 02$ & 199 & 183 & 177 & 174 & 167 & & & \\
\hline 299-W11-12 & 131.8 & 136.827 & $6 / 02$ & 199 & 182 & 178 & \begin{tabular}{|l|} 
Not Present \\
\end{tabular} & 169 & & & \\
\hline 299-W11-23 & 133.7 & NA & NA & 195 & 183 & 178 & 173 & 172 & & & \\
\hline 299-W11-24 & 133.5 & 136.761 & $6 / 02$ & 199 & 181 & 179 & 176 & 169 & & & \\
\hline $299-W 11-25$ B $^{(\mathrm{c})}$ & 85.7 & 136.7 & $3 / 04$ & 198 & 183 & 180 & 174 & 170 & 86 & & \\
\hline 299-W11-26 & 88.0 & NA & NA & 196 & 179 & 178 & 174 & 169 & 86 & 80 & 58 \\
\hline 299-W11-27 & 137.3 & NA & NA & 198 & 183 & 180 & 173 & 170 & & & \\
\hline 299-W11-28 & 136.0 & 141.621 & $2 / 99$ & 199 & 182 & 179 & 175 & 168 & & & \\
\hline 299-W11-30 & 128.4 & 136.354 & $5 / 02$ & 203 & 182 & 215 & 171 & 163 & & & \\
\hline 299-W11-39 & 123.8 & 136.788 & $5 / 02$ & 200 & 183 & 179 & 174 & 170 & & & \\
\hline 299-W11-40 & 124.4 & 136.807 & $5 / 02$ & 200 & 183 & 178 & 174 & 169 & & & \\
\hline 299-W11-41 & 124.3 & 136.78 & $6 / 02$ & 198 & 182 & 179 & 174 & 170 & & & \\
\hline 299-W11-42 & 124.8 & 136.85 & $5 / 02$ & 198 & 182 & 180 & 173 & 169 & & & \\
\hline $\begin{array}{ll}\text { (a) Tops are ele } \\
\text { (b) Elevation at } \\
\text { (c) Not surveye } \\
\text { Bold text indicate }\end{array}$ & $\begin{array}{l}\text { tion above sea le } \\
\text { mpletion depth. } \\
\text { the time of rep } \\
\text { vells are in the g }\end{array}$ & $\begin{array}{l}\text { vel in meters. } \\
\text { ort preparation. } \\
\text { oundwater mon }\end{array}$ & $\begin{array}{l}\text { Assumes elevat } \\
\text { hitoring network. }\end{array}$ & ion equal to 299- & V11-39, locate & m away. E & ion $=210.55$. & & & & \\
\hline
\end{tabular}




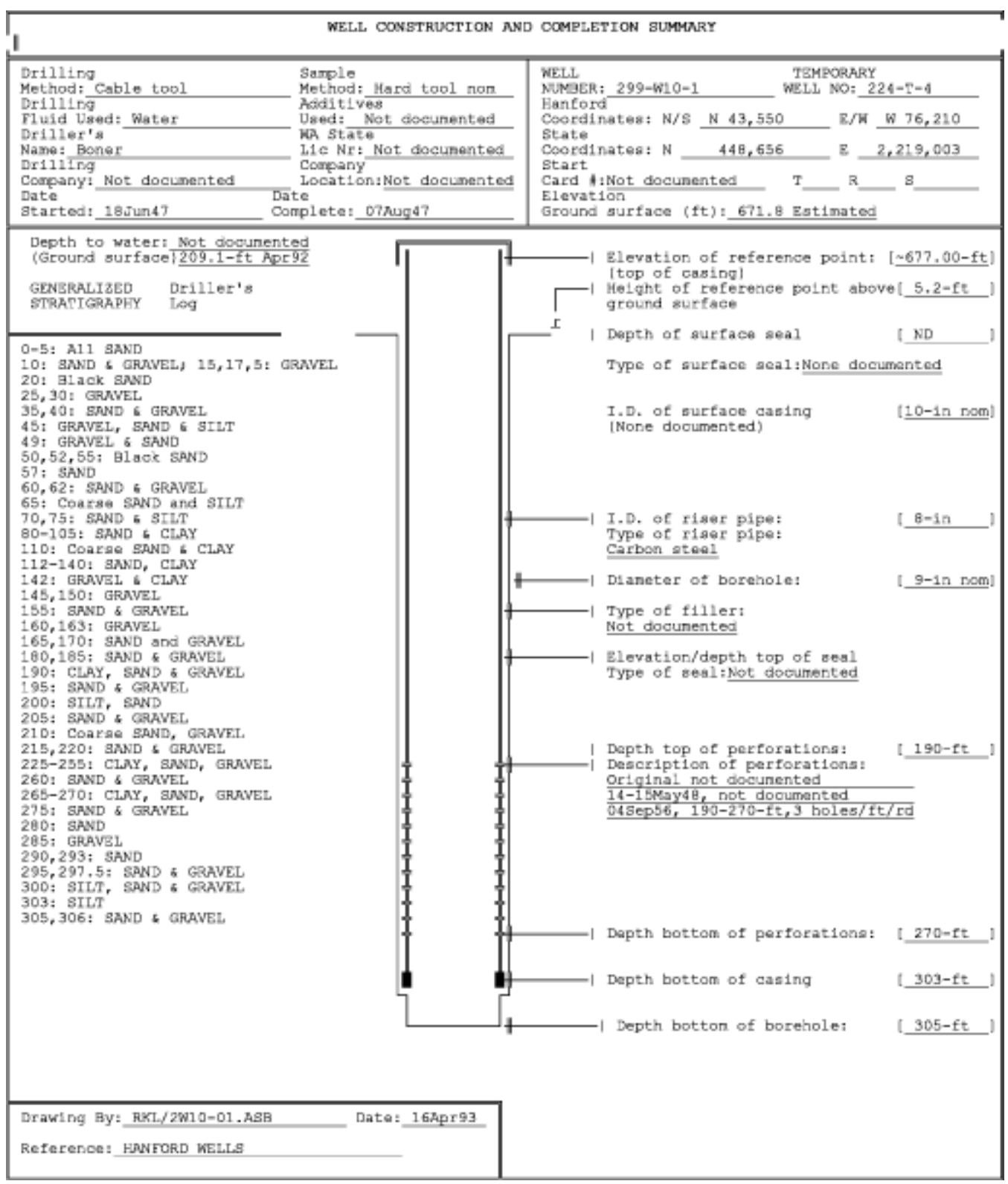




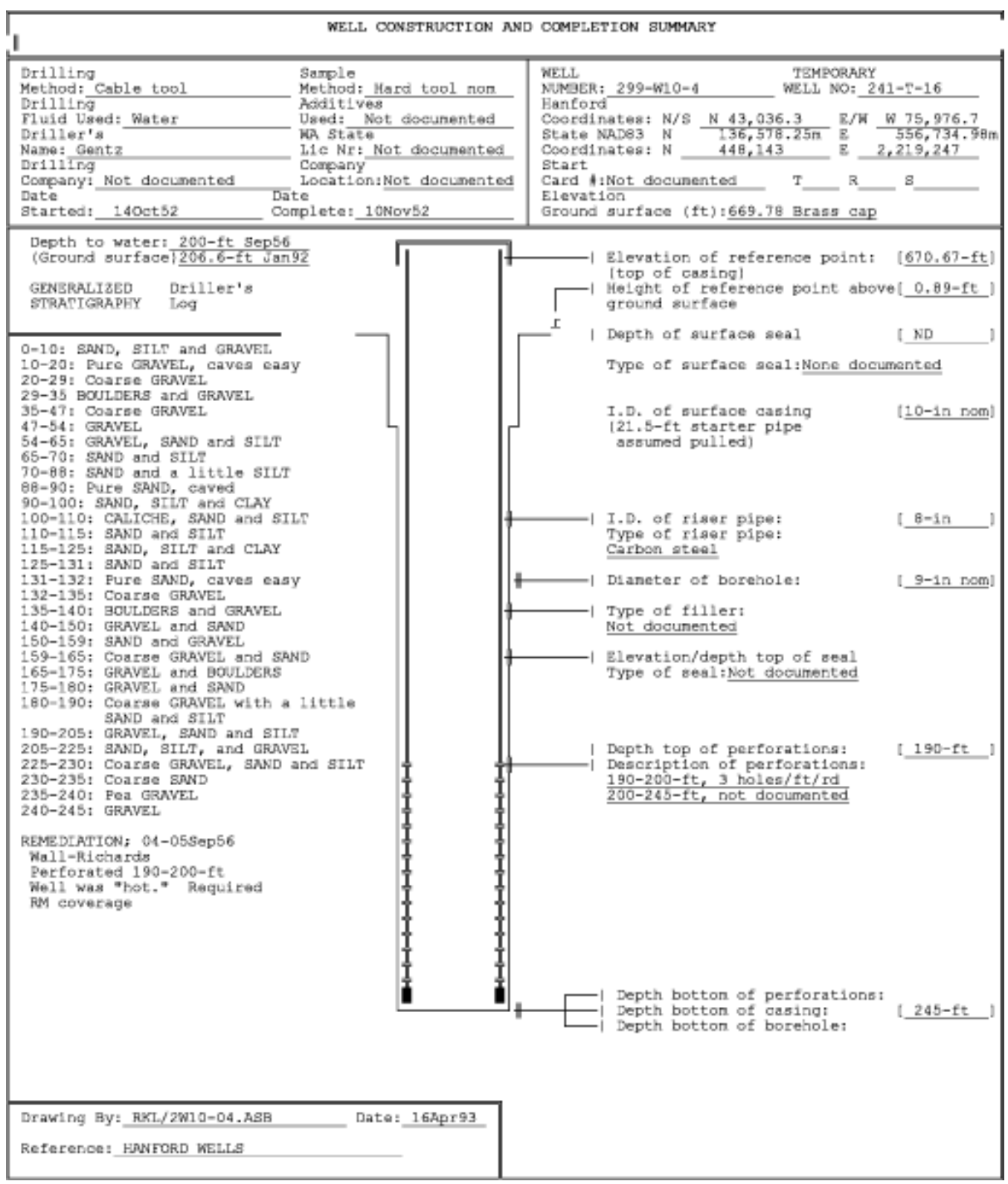




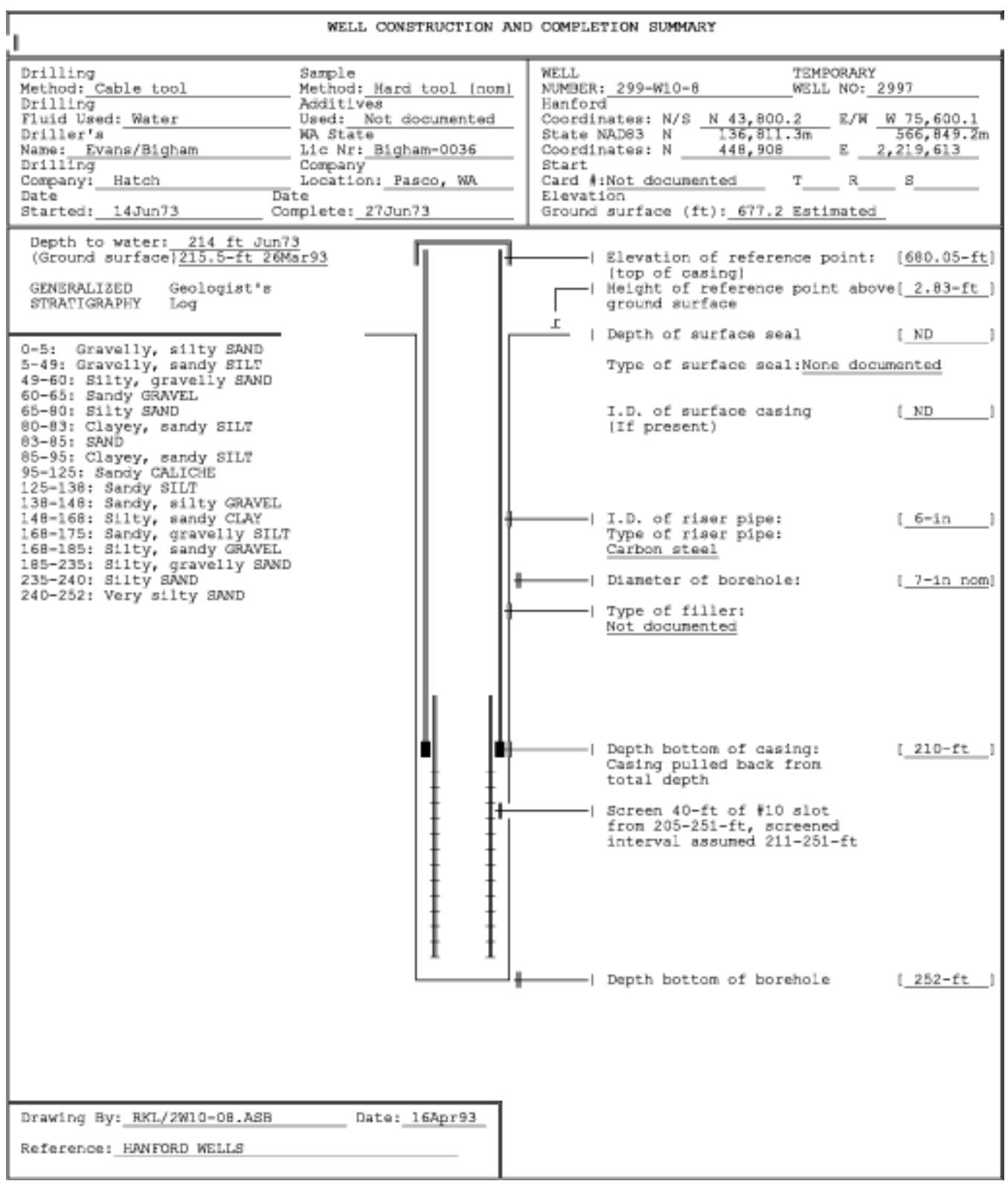


0500652

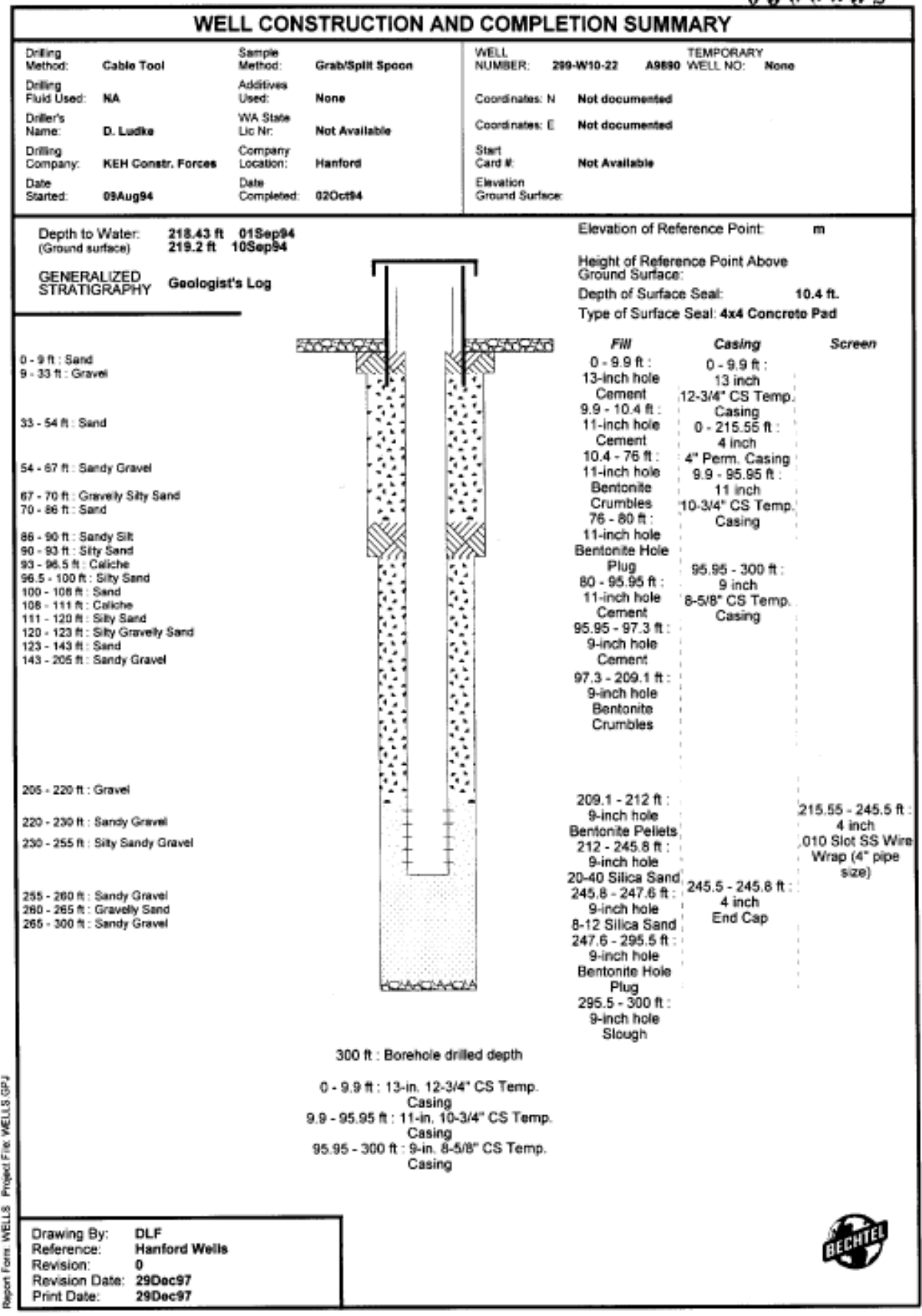


0512638

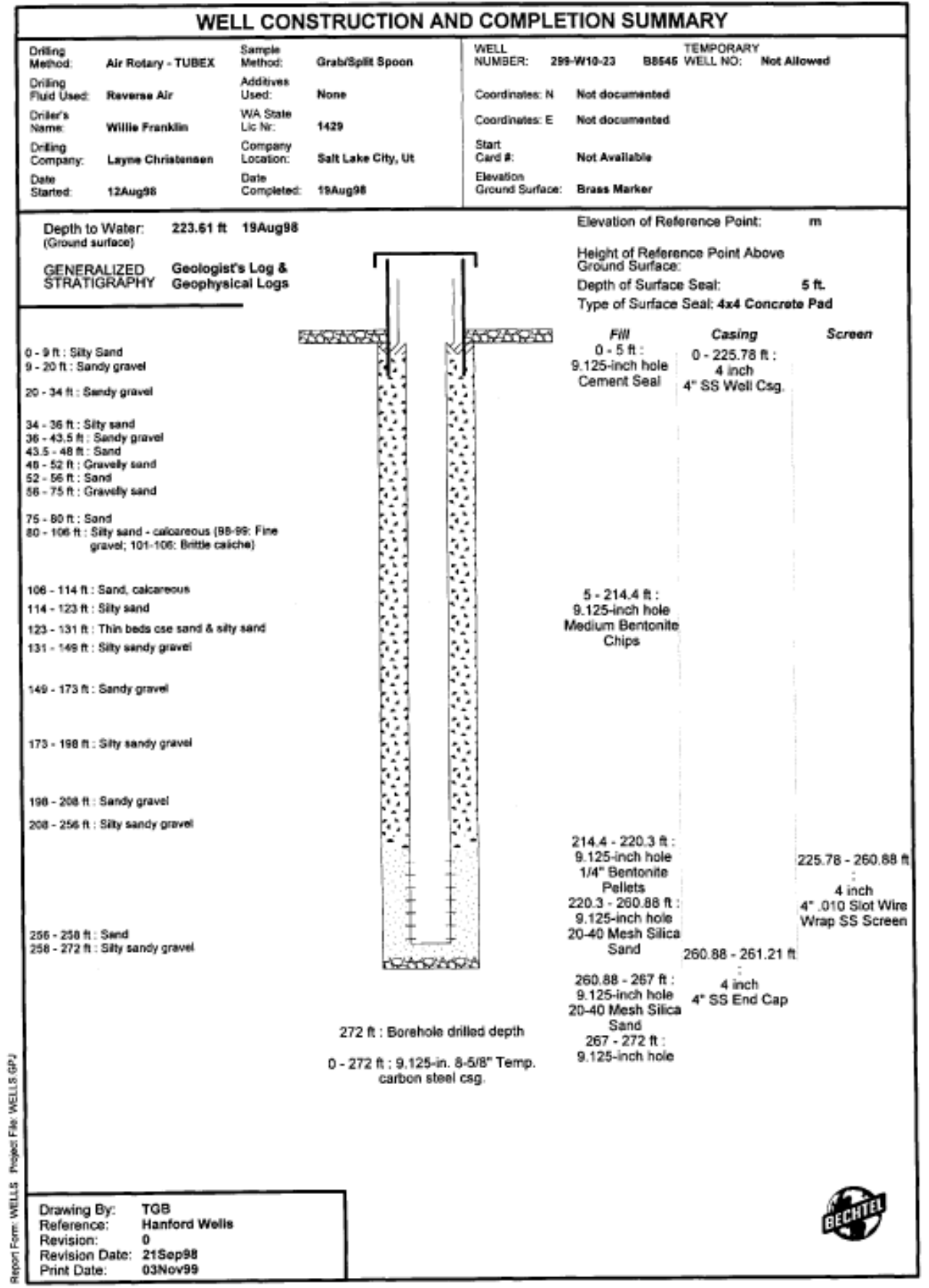


0502369

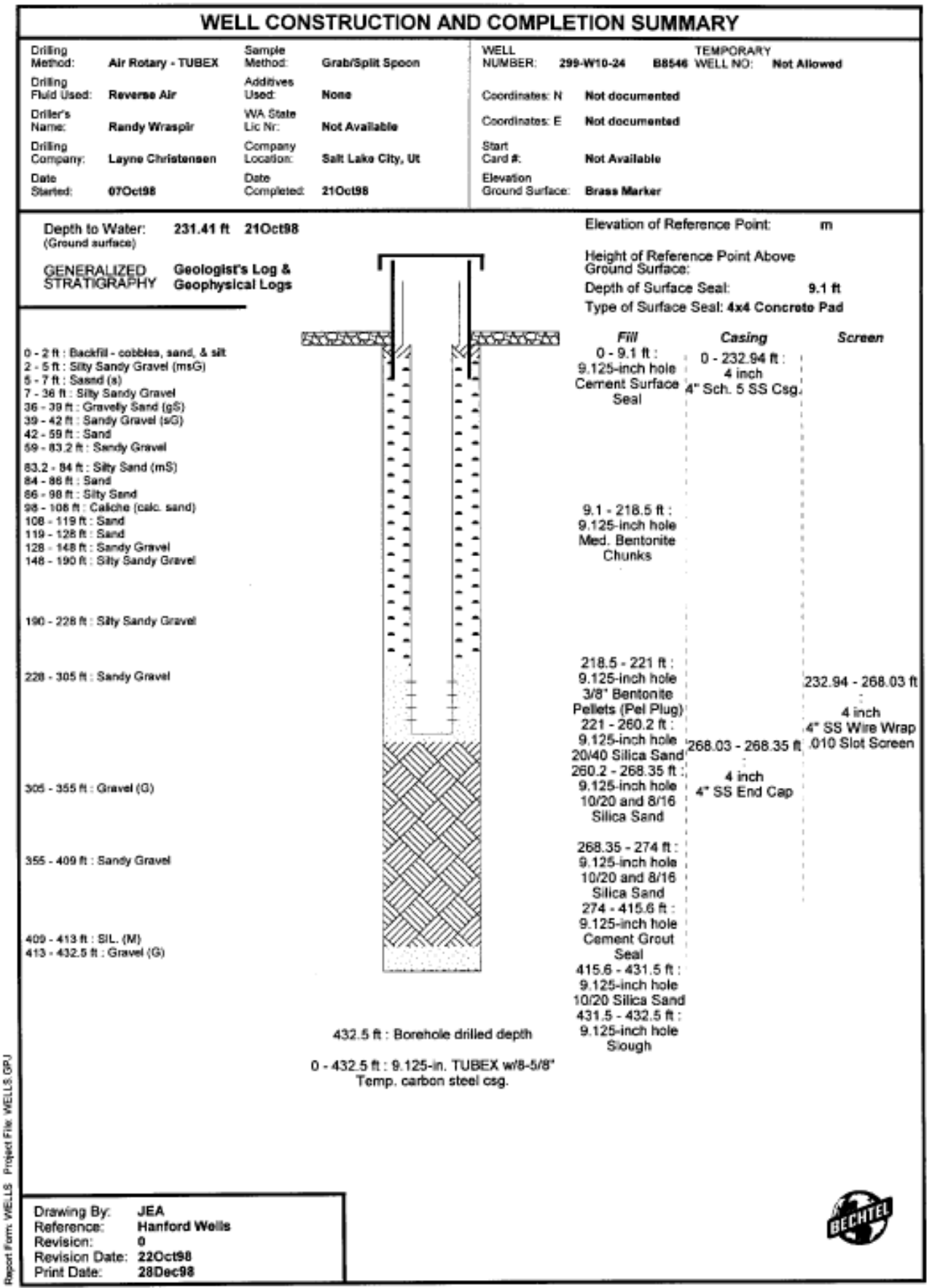


0540437

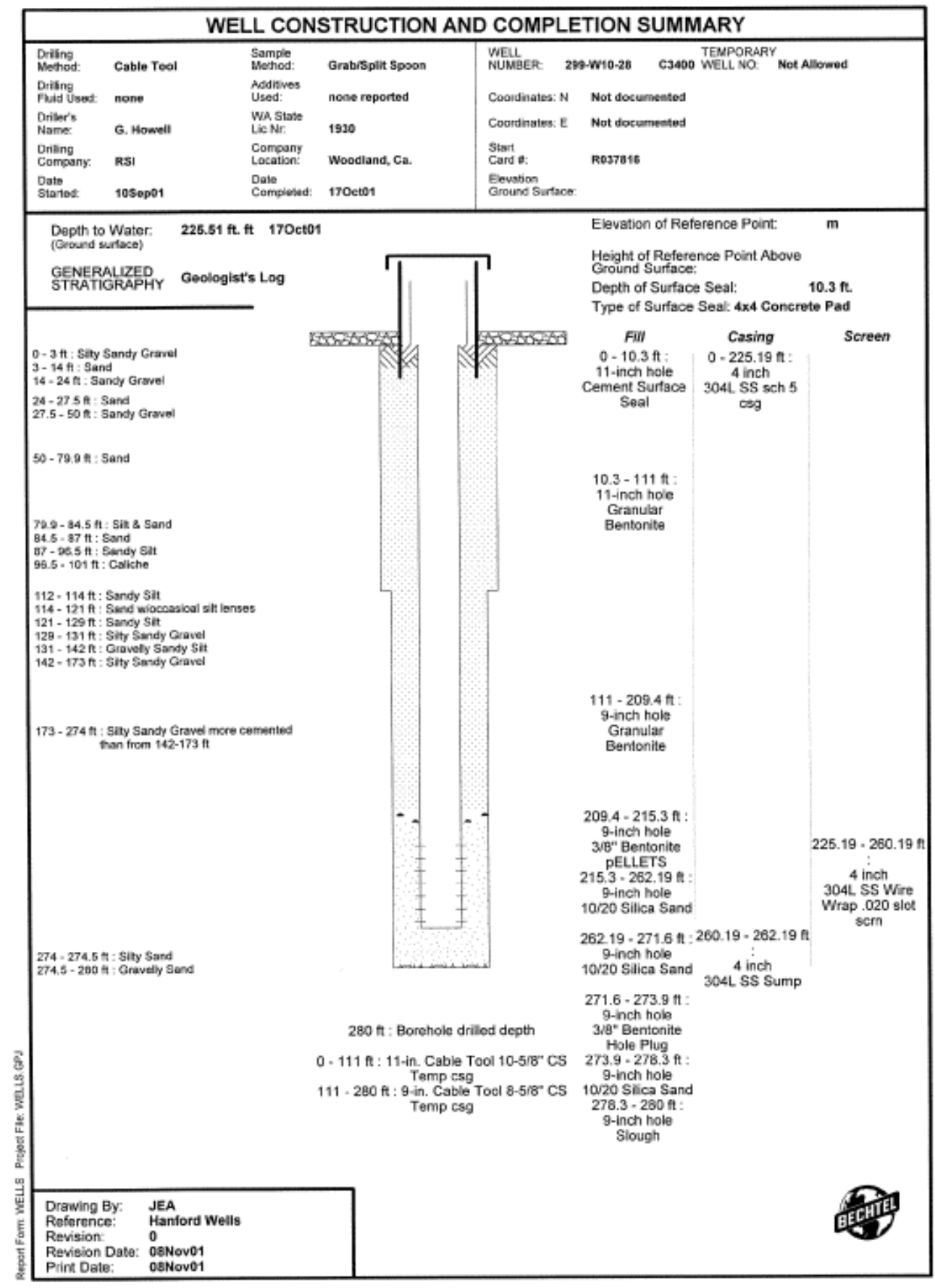




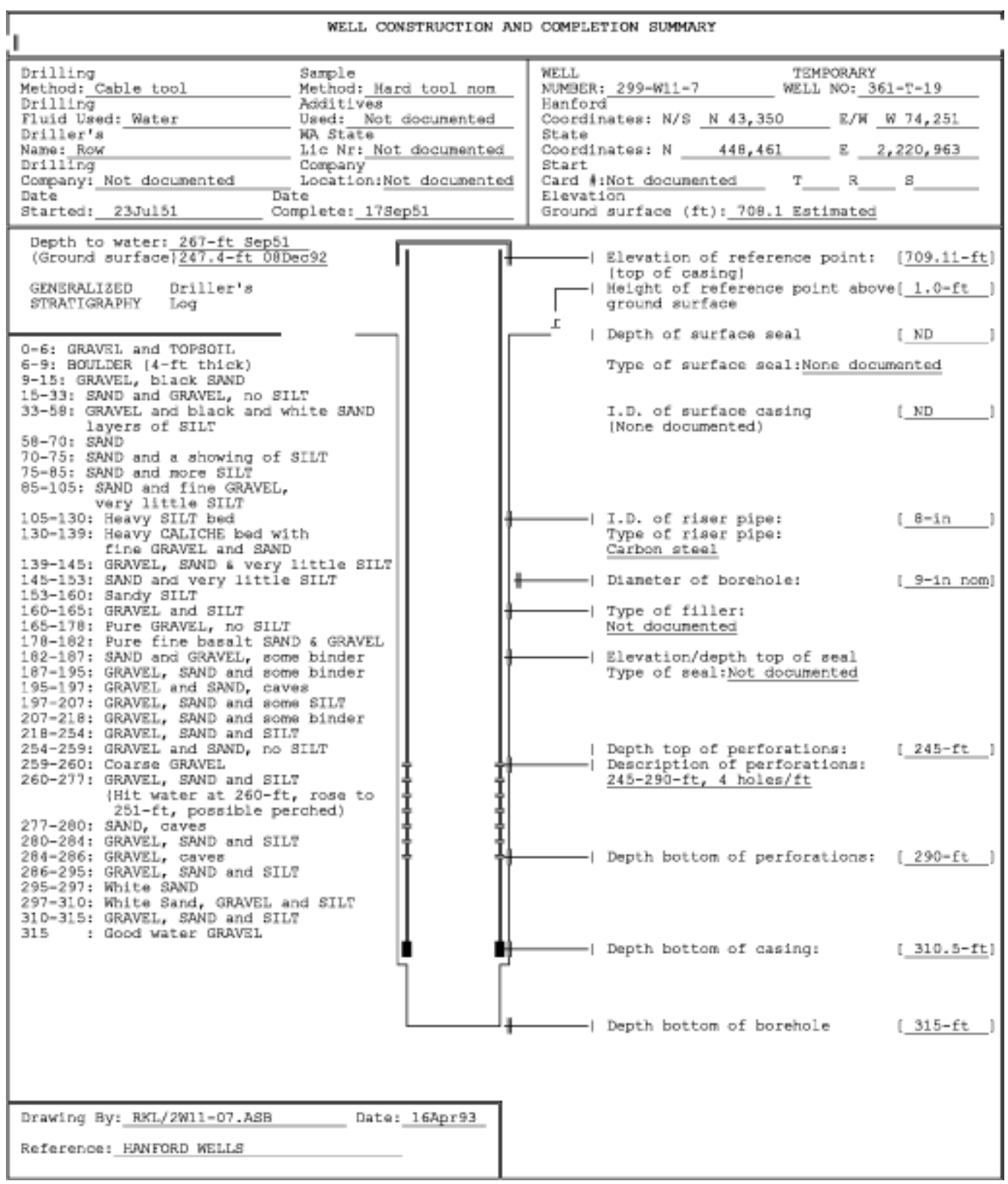




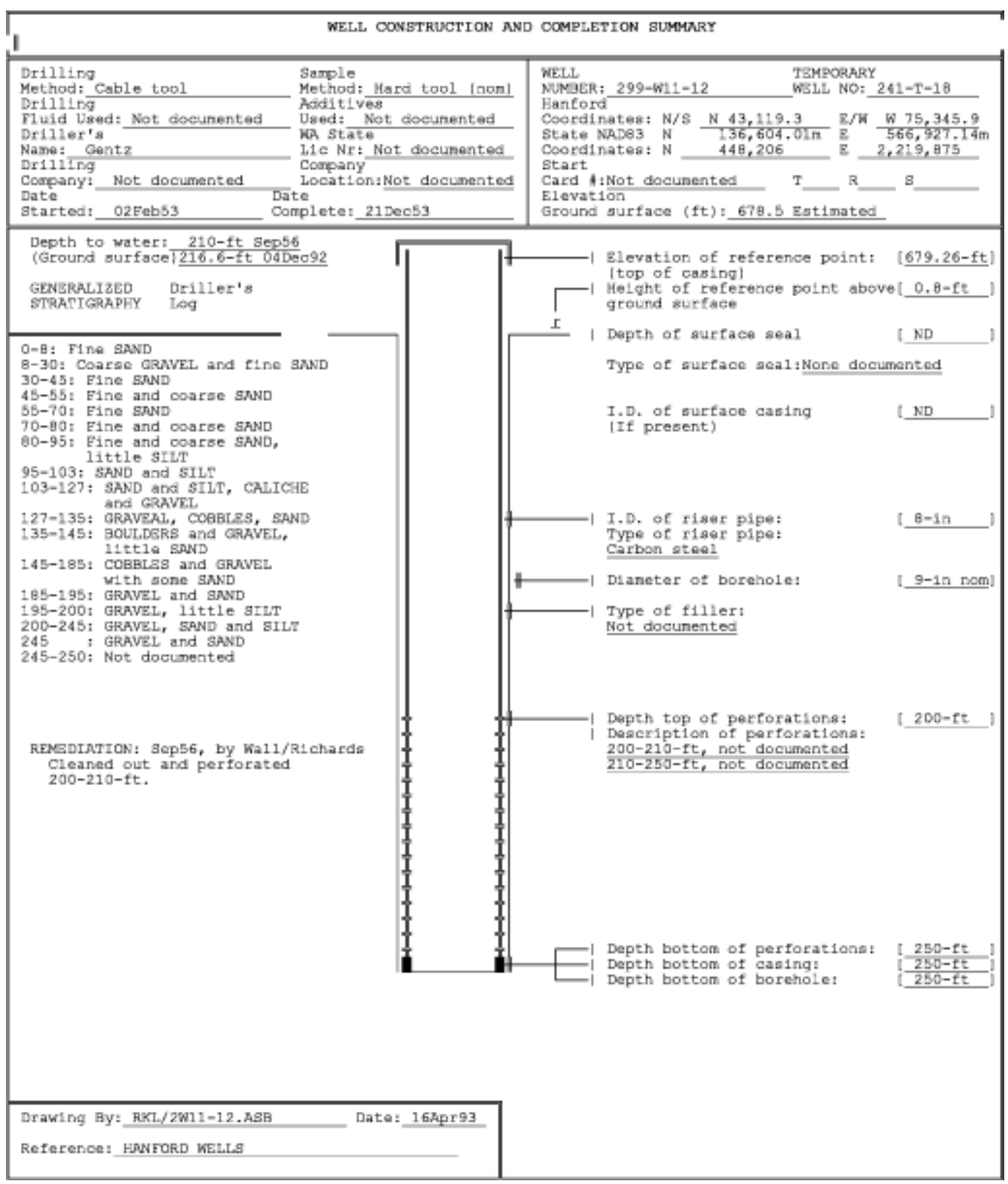


0532876

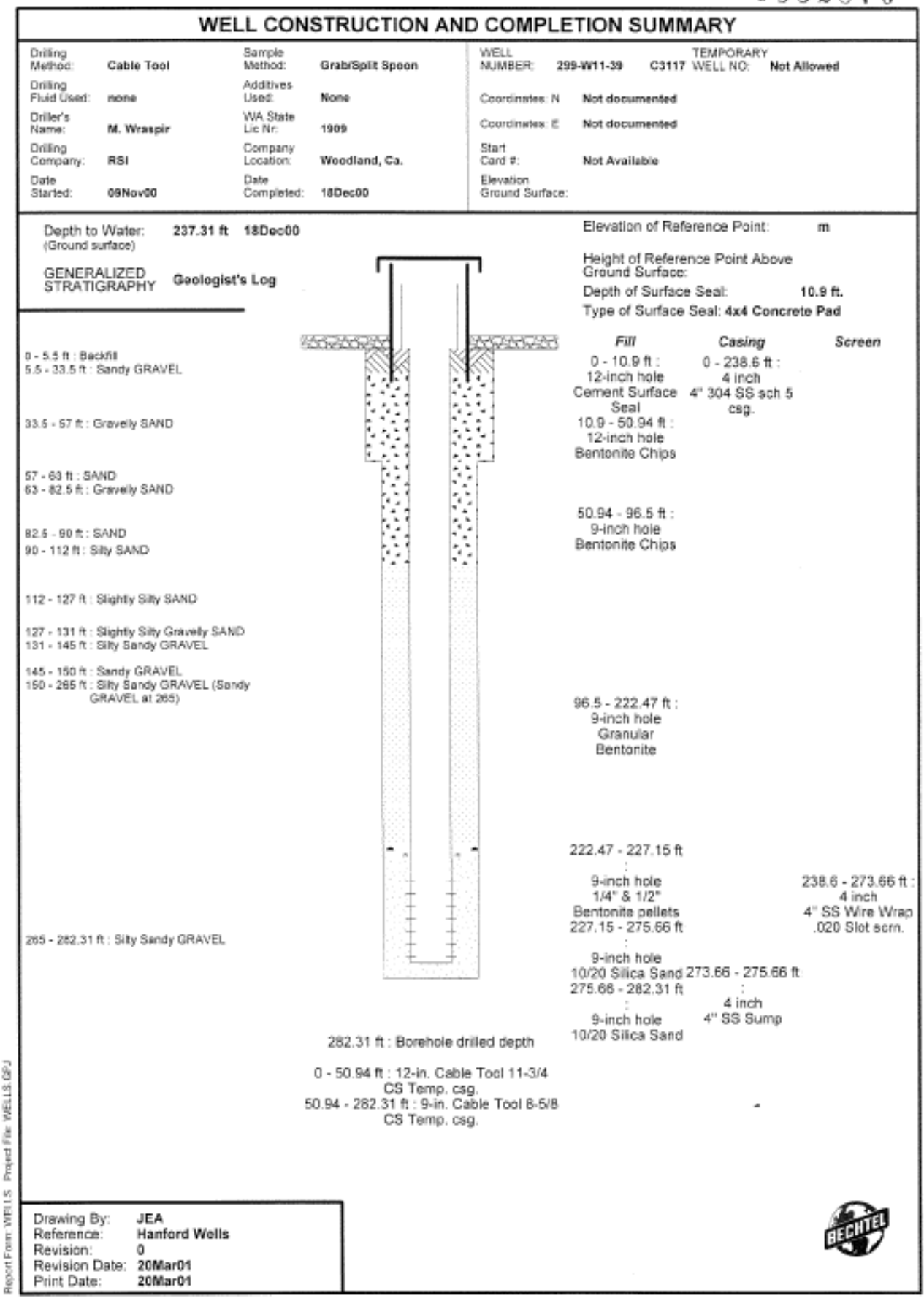


0532874

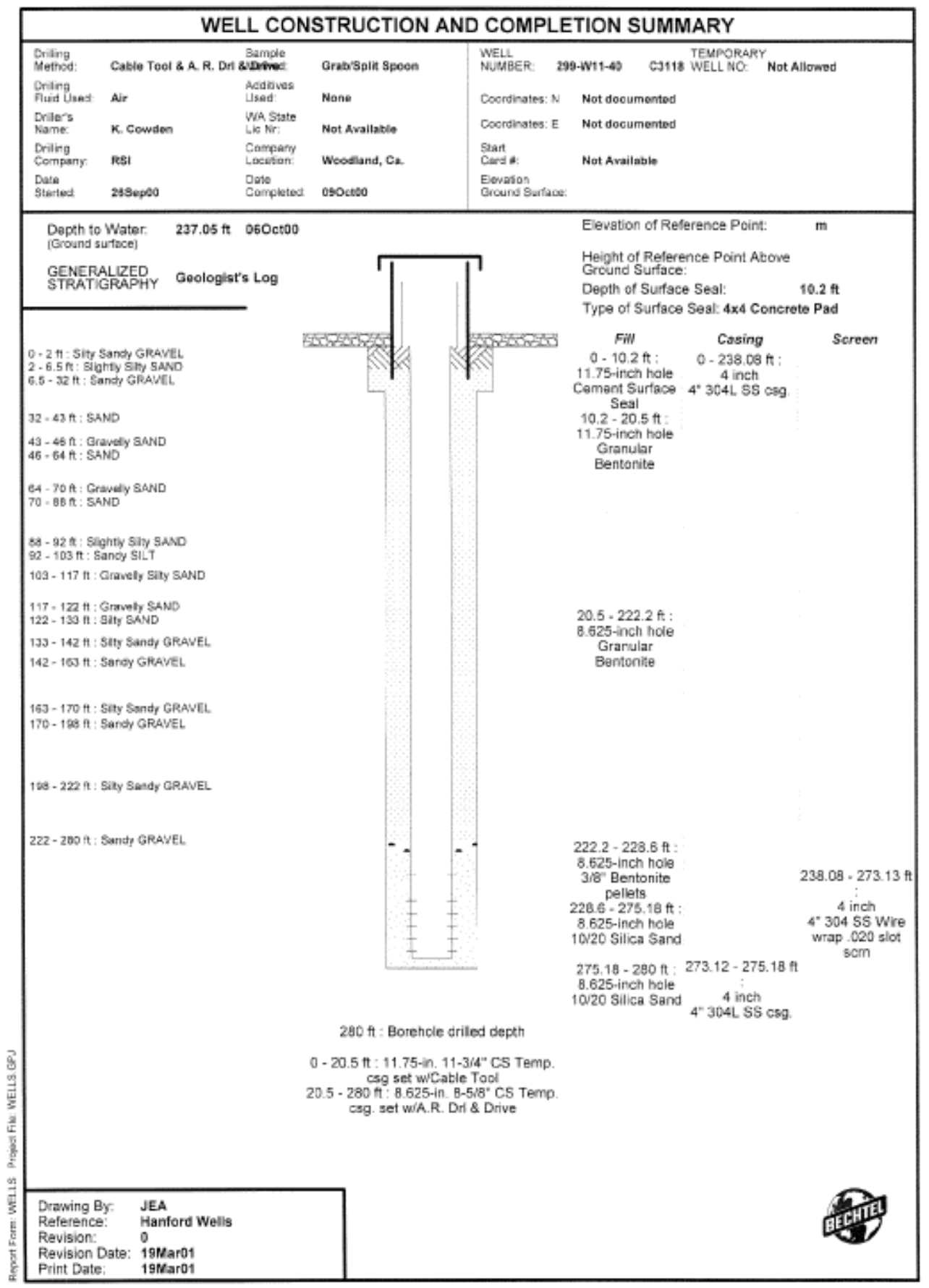


0526560

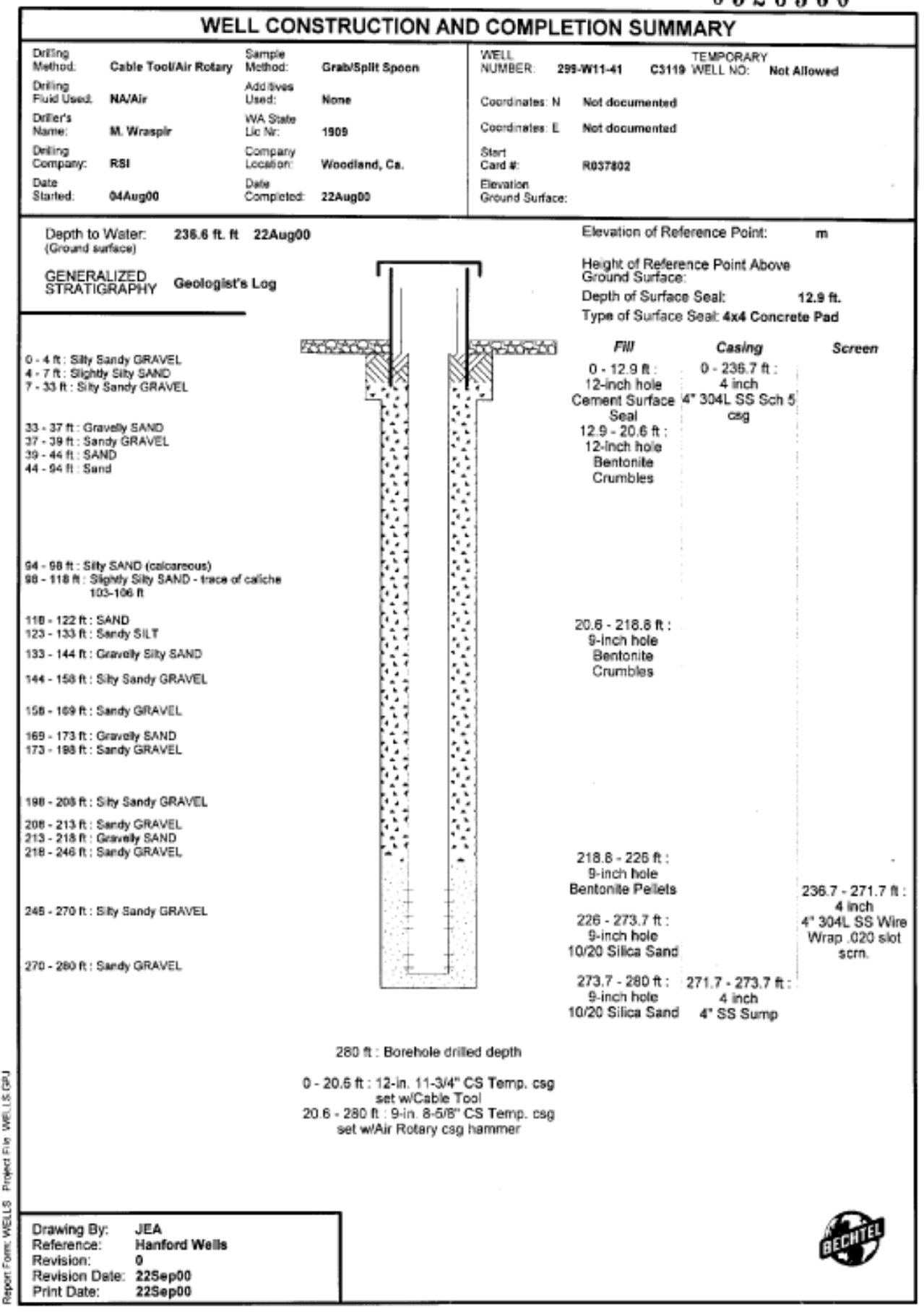




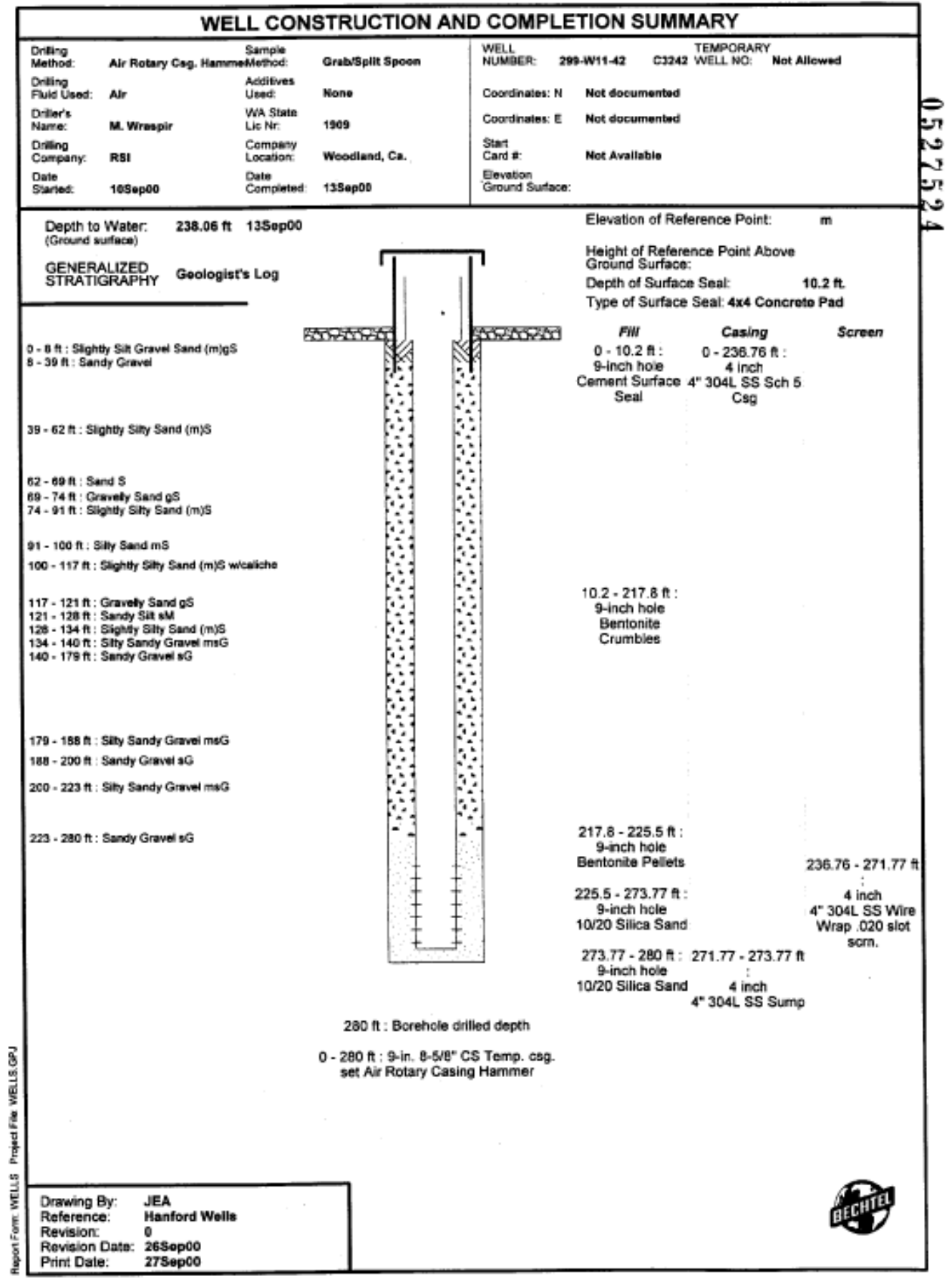




\section{Distribution}

No. of

Copies

\section{OFFSITE}

2 Confederated Tribes of the Umatilla Indian Reservation

P.O. Box 638

Pendleton, OR 97801

ATTN: The Honorable W. Burke T. Rapaske

R. Jim, Manager

Environmental Restoration/

Waste Management Program

Confederated Tribes and Bands of the Yakama Indian Nation

P.O. Box 151

Toppenish, WA 98948

2 Nez Perce Tribe

P.O. Box 365

Lapwai, ID 83540

ATTN: D. Powaukee

D. Landeen

S. Van Verst

Washington State Department of Health

Division of Radiation Protection

P.O. Box 47827

Olympia, WA 98504
No. of

Copies

3 Bechtel Hanford, Inc.
J. V. Borghese
E6-35
G. D. Cummins
H8-12
B. H. Ford
E6-35

2 CH2M HILL Hanford Group, Inc.
F. J. Anderson
E6-35
D. A. Myers
E6-35

2 U.S. Environmental Protection Agency
C. E. Cameron
B1-46
D. A. Faulk
B1-46

3 Washington State Department of Ecology
J. Caggiano
H0-57
D. Goswami
$\mathrm{H} 0-57$
J. A. Hedges
$\mathrm{H} 0-57$

7 Pacific Northwest National Laboratory
P. E. Dresel
K6-96
D. G. Horton (3)
K6-75
S. P. Luttrell
K6-96
Hanford Technical Library (2)
P8-55

\section{ONSITE}

\section{DOE-Richland Operations Office}
R. D. Hildebrand
A6-38
R. W. Lober
H6-60
K. M. Thompson
A6-38
A. C. Tortoso
A6-38
Public Reading Room (2)
$\mathrm{H} 2-53$ 